Universidade de São Paulo

Instituto de Química-Dept. Bioquímica

\title{
Seqüenciamento e Anotação de Parte do \\ Genoma de Xylella fastidiosa
}

Dissertação de Mestrado em Bioquímica Adriana Yamaguti Matsukuma Orientador: Sergio Verjovski-Almeida

São Paulo SP

2000 


\section{"Seqüenciamento e Anotação de Parte do Genoma de Xylella fastidiosa".}

\section{ADRIANA YAMAGUTI MATSUKUMA}

DISSERTAÇÃO DE MESTRADO SUBMETIDA AO INSTITUTO DE QUÚMICA DA UNIVERSIDADE DE SÃO PAULO COMO PARTE DOS REQLUSTIOS NECESSÁRIOS À OBTENÇÃO DO GRAU DE MESTRE EM CIENCIAS - ÁREA: BIOQUÚMICA.

Aprovada por:

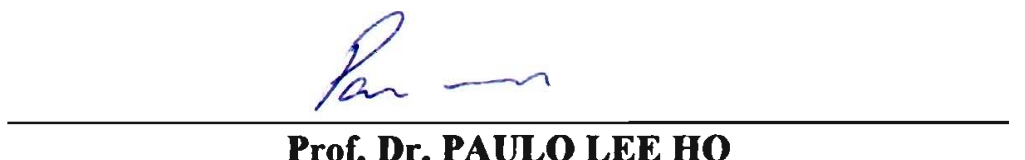

Prof. Dr. PAULO LEE HO

(Presidente)

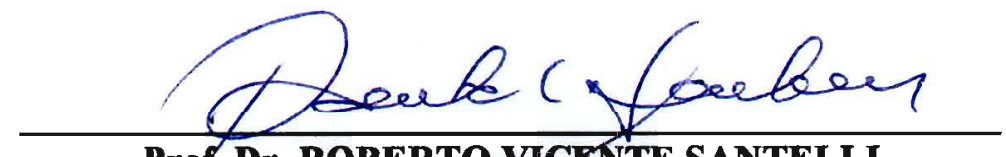

Prof. Dr. ROBERTO VICETTE SANTELLI

IQ - USP

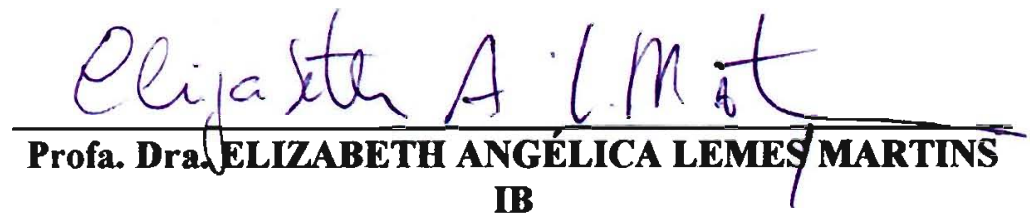

O9 DE FEVEREIRO DE 2001. 


\section{Agradecimentos}

Ao Prof.Dr. Sergio Verjovski-Almeida pela confiança ao me entregar esse projeto e pelo tamanho exemplo de profissionalismo, trabalho e dedicação a, muitas vezes, tão árduo trabalho e caminho que escolhemos.

$\mathrm{O}$ ambiente profissional muitas vezes se reflete em nosso trabalho e por isso agradeço aos colegas de laboratório: Marie Parat-Salvado, Bernardo Peixoto, Eduardo Reis, Juliana Fietto, Ricardo De Marco, Paulo César, Rodrigo Louro, Ana, Juliana Michaeli, Angélica, Célia, Franco, Katlin, Flávio, Ana Paula, André, Ana Cláudia, Milton, Apuã, Felipe e Rafael pela amizade, compreensão, paciência e ensinamentos durante o decorrer do projeto.

Agradeço principalmente aos amigos Gilson Soares Baia e Renato Alvarenga pelo apoio, companheirismo, trabalho, aprendizado e cumplicidade desses mais de dois anos. As muitas risadas que demos e conversas que tivemos serão inesquecíveis.

Ao Jefferson pela amizade e à Ivone que sempre demonstrou um exemplo de vida com sua inabalável alegria e esperança.

Uma particularidade deste projeto e uma das razão de seu "sucesso" foi o trabalho em equipe e por isso agradeço a todos os envolvidos direta ou indiretamente no Projeto Genoma Xylella fastidiosa. Agradeço às amizades obtidas através do projeto e suas extensões: Profas.Dras Edna Kimura, Mari Sogayar, Gláucia, Ana Cláudia e Aline Maria; Profs Drs Hamza El-Dorry, Arthur Grüber e Ronaldo Quaggio; Alexandre Sanchez, Denise Yamamoto, Luciana Terumi, Mara, Daniela Miranda, Daniella Stecconi, Christian, Camila, João, Juliana, Cyntia, Rebecca e Gleisa.

Em especial, agradeço aos amigos "xylellicos" de mestrado Ari José Scattone Ferreira, Cássia Docena e Cássio da Silva Baptista pelas discussões, respostas, apreensões, indecisões, alegrias e muitas risadas divididas durante todo esse período.

Aos antigos amigos que dividiram as indecisões de adolescência, provando que uma amizade verdadeira continua mesmo com escolhas e caminhos tão distintos: Angélica Kaoru Kajimoto, Cristina Satomi Takano, Douglas Vasconcelos, Flávia Midori Mori, Miriam Akemi, Mirian Mina, Patrícia Lumi e Ricardo Régis. Por todo apoio, paciência e lembranças. 
Aos mais novos amigos da "diretoria" que tornaram as noites singulares e divertidas: Carlos Eduardo Sanchez, Cristiane Ryiumi Yumioka, Cristiano, Denise Maria, Edson Kanagusuko, Geraldo Marcelo, Osmar, Raphael Lemos Maia, Renato Manente Barbosa, Regina Célia N. Galhardo e Sheila Carvalho.

Um ambiente familiar também caracteriza um aspecto essencial para o sucesso e progresso de um trabalho e de vida. Agradeço meus irmãos Robinson e Aline pela amizade e principalmente pela paciência, preocupação e interesse. A meus pais, Tadayoshi e Yaeko que propiciaram, através de muito sacrificio, o conhecimento que hoje tenho, tanto de estudo como de vida; a melhor herança que alguém pode receber.

Ao Carlos Egydio de Carvalho que, embora muito distante sempre se mostrou presente com seu carinho, amor, preocupação, apoio e críticas ao meu trabalho. Agradeço por tudo que com ele aprendi e continuo aprendendo tanto profissional como pessoalmente. Extendo meus agradecimentos à seus pais e irmãos que sempre me trataram como parte da família.

Agradeço à Fundação de Amparo a pesquisa no Estado de São Paulo (FAPESP) e ao Conselho Nacional de Pesquisa (CNPq) pelas bolsas de aperfeiçoamento e mestrado, respectivamente, a mim concedida durante $o$ desenvolvimento desse projeto. 


\section{Índice}

\section{Introdução}

I.1. Importância da citricultura paulista

I.2. Clorose Variegada dos citros

I.2.1. Histórico

I.2.2. Sintomas

I.3. Hipóteses do agente causal da CVC

\section{I.4. Xylella fastidiosa}

I.4.1. Taxonomia

I.4.2. Morfologia

I.4.3. Transmissão

I.4.4. Características do habitat

I.4.5. Patogenicidade

I.4.6. Detecção

I.5. Projeto Genoma Xylella fastidiosa

\section{Objetivos}

\section{Materiais e Métodos}

III.1. Cepas bacterianas utilizadas

III.2. Vetores utilizados

III.3. Primers utilizados

III.4. Seqüenciamento do genoma de Xylella fastidiosa

III.4.1. Seqüenciamento de clones das bibliotecas randômicas 00 e 03

III.4.2. Construção das sub-bibliotecas de "shotgun"

III.4.3. Preparo dos templates para seqüenciamento

III.4.4. Seqüenciamento dos insertos

III.4.5. Preparo dos templates e seqüenciamento diretamento do genoma de Xylella fastidiosa

III.4.6. Seqüenciamento total de clones provenientes das bibliotecas de "shotgun" genômico

III.5. Montagem dos cosmídeos a partir dos cromatogramas obtidos

III.6. Predição de ORFs nos cosmídeos

III.7. Anotação de ORFs

\section{Resultados}


IV. 1. Cosmídeos

IV.1.1. Cosmídeo X0QV-07B03

IV.1.2. Cosmídeo X0QV-11B08

IV.1.3. Cosmídeo X0QV-08A03

IV.1.4. Cosmídeo X0QV-03D03

IV.1.5. Cosmídeo X0QV-04A09

IV.1.6. Cosmídeo X0QV-10F11 e X0QV-20F11

IV.1.7. Cosmídeo X0QV-06H03

IV.2. Bibliotecas de "shotgun" genômico

IV.3. Clones "shotgun" - GFSs ("gap filling sequences")

IV.4. Biblioteca RDA ("Representational difference analysis")

IV.5. Anotação

\section{V.Discussão}

\section{Bibliografia}

\section{Apêndice}

A. Xylella fastidiosa Genome Features

B. Grupos envolvidos no Projeto Genoma Xylella fastidiosa

C. Tabela de cosmídeos seqüenciados para a montagem do genoma de Xylella fastidiosa (Em vermelho os cosmídeos X0QV)

D. Bibliotecas de "shotgun" genômico construídas

E. Tabela de clones das bibliotecas de "shotgun" genômico seqüenciados

F. Primers construídos para a finalização dos cosmídeos

G. Tabela de clones das bibliotecas de "shotgun" totalmente seqüenciados $\left(0^{*} \mathrm{~J}^{* *}\right)$, gaps $\left(00 \mathrm{I}^{* *}\right)$ ou clones das bibliotecas lambda $\left(0^{*} \mathrm{~L}^{* *}\right)$ - GFSs

H.Cosmídeos X0QV

H.1. Cosmídeo X0QV-03D03

H.2. Cosmídeo X0QV-04A09

H.3. Cosmídeo X0QV-06H03

H.4. Cosmídeo X0QV-07B03

H.5. Cosmídeo X0QV-08A03

H.6. Cosmídeo X0QV-10F11

H.7. Cosmídeo X0QV-20F11

H.8. Cosmídeo X0QV-11B08

I. Clones "shotgun" - GFSs ("gap filling sequences")

I.1. GFS X0QV-00J18 (X0QV0010G03)

I.2. GFS X0QV-00J19 (X0QV1067G10) 
I.3. GFS X0QV-00J34 (X0QV1034E07)

I.4. GFS X0QV-00J53 (X0QV1034H11)

I.5. GFS X0QV-00J67 (X0QV0010C05)

I.6. GFS X0QV-07J24 (X0QV0724G04)

I.7. GFS X0QV-10J64 (X0QV1064D09)

J. Classification of E.coli genes products (Monica Riley)

$\mathrm{K}$. Table for Xylella fastidiosa genome

L. Protocolos

Soares)

L.1. Protocolo para Miniprep (adaptado pelo Prof. Dr. Marcelo Bento

L.2. Preparação de células eletrocompetentes

L.3. Preparação de células quimio-competentes

L.4. Boiling 96-well plasmid miniprep

Curriculum vitae 


\section{Resumo}

A citricultura paulista pode ser considerada uma das mais competitivas e importantes atividades agroindustriais do Brasil, gerando aproximadamente 400 mil empregos e adicionando anualmente U\$ 1,4 bilhões ao país. Entretanto ainda apresenta uma produtividade inferior àquela encontrada na Flórida, principalmente devido a deficiências nutricionais e hídricas e a doenças que há diversos anos atingem as lavouras.

Nos últimos dez anos a clorose variegada dos citros (CVC), conhecida popularmente como a doença do amarelinho, apresenta-se como o principal problema, sendo a bactéria gram-negativa Xylella fastidiosa seu agente causal. Em vista da importância do cultivo da laranja no país, o projeto "Genoma Xylella fastidiosa" foi proposto, visando o seqüenciamento total do genoma deste fitopatógeno bem como o treinamento de pessoal capacitado na utilização das modernas técnicas de biologia molecular.

Segmentos de DNA provenientes de 7 cosmídeos e diversos clones provenientes de bibliotecas de "shotgun" genômico foram seqüenciados em nosso laboratório, totalizando $271.220 \mathrm{pb}$ do genoma da bactéria. Em seguida foi feita a anotação das orfs preditas por programa GLIMMER, sendo que em nosso laboratório foram anotadas aproximadamente $290 \mathrm{ORFs}$.

Seqüenciamentos diretamente do genoma e de clones das bibliotecas de RDA foram também realizados, complementando as metodologias de primer walking e construção de bibliotecas de fago utilizadas em outros laboratórios do projeto para o fechamento de "gaps".

Todos os resultados obtidos em nosso laboratório, somados às contribuições de todos os grupos do projeto, serão base para a melhor compreensão dos mecanismos utilizados pela bactéria, podendo favorecer o desenvolvimento de novas estratégias para o combate desta praga. 


\begin{abstract}
The São Paulo's citriculture can be considered one of the most competitive and important agroindustrial activity from Brazil. It provides aproximately 400,000 jobs and adds US\$1,4000,000,000 for the country's economy. This activity, however, still shows less productivity than the one from Florida, mainly due to nutritional and hydric deficiencies and plagues that are already present for a long time.

In the last ten years, the citrus variegated chlorosis (CVC), also known as little yellow disease, constitutes the main problem for the orange farmers. This disease is caused by gram-negative bacterium Xylella fastidiosa. Due to the importance of the orange cultive in the country, the project called Xylella fastidiosa's Genome was proposed. The main goals of this project are to sequence the entire genome of this phytopathogen and the trainning of specialized people in the use of modern techniques of molecular biology.

DNA fragments cloned in 7 cosmids and also form genomic shotgun libraries were sequenced in our laboratory. A total of $271,220 \mathrm{bp}$ of bacteria genome were obtained. The next step was the annotation of the open reading frames (ORFs). This was made using the GLIMMER computer program which generates, in our laboratory, aproximately 290 ORFs.

Direct sequencing of the genome and clones of RDA libraries were also done for obtaining nucleotide sequences form gaps. These methodologies complement the primer walking and phage library construction used by other laboratories included in the project.

All results, obtained either by our laboratory or the other groups from the project, will be used for a better understanding of the mechanisms used by the bacteria, Altogether, they can be favor the development of new strategies in the plague combact.
\end{abstract}




\section{Introdução}

\section{I.1. Importância da citricultura paulista}

Em 1996, nas estatísticas sobre a fruticultura mundial, os citros ocuparam o 1 'lugar com um volume físico de produção que alcançou $22,8 \%$ (93,8 milhões de toneladas) da produção total mundial (411,6 milhões de toneladas), à frente das bananas, uvas e maças.

$\mathrm{Na}$ citricultura mundial, a laranja com 63,2\% (59,7 milhões de toneladas) da produção de citros se constituiu na rainha das frutas, por ser a mais conhecida e apresentar o maior volume de produção.

Embora seja cultivada em mais de 100 países, a produção de laranja mostra uma distribuição pouco uniforme. Em 1996, apenas dois países - Brasil $(34,8 \%)$ e os EUA $(17,8 \%)$ - detiveram ao redor de $52 \%$ da produção, ficando a outra parte dividida com mais de 100 países.

Sendo assim, a citricultura pode ser considerada uma das mais competitivas e importantes atividades agroindustriais do Brasil, distribuindo-se, porém, de forma desigual entre os estados. Segundo dados do FIBGE (1996), apenas 4 Estados produziam cerca de $94 \%$ da produção: São Paulo $(82,9 \%)$, Sergipe $(4,01 \%)$, Bahia $(3,7 \%)$ e Minas Gerais $(3,29 \%)$.

No Estado de São Paulo existem quase 20 mil estabelecimentos agrícolas espalhados em 204 municípios, 12 empresas de produção industrial, gerando aproximadamente 400 mil empregos diretos, desde a produção, assistência técnica e adubação, até o transporte e embarque do produto $(38,39)$. Além disso, a exportação de suco de laranja concentrado adiciona, anualmente, um valor aproximado de US\$ 1.4 bilhões ao país.

A produção de laranja atende à indústria (71,5\%), ao consumo de fruta fresca (28\%), e à exportação (0,5\%). Entre 1995/96, os principais importadores do suco brasileiro foram a União Européia (68,8\%), América do Norte (18,5\%) e Ásia (9,5\%), sendo que só o Estado de São Paulo responde por $96,4 \%$ do volume total esperado (39).

O Brasil responde por mais de metade (1.146,9 mil toneladas) do volume mundial de suco concentrado (61 ${ }^{\circ}$ Brix) que em 1994 alcançou o volume de 
2.138.500 mil toneladas. Em uma área de aproximadamente 630.000 hectares, São Paulo possui aproximadamente 164 milhões de árvores com uma produção anual de 374 milhões de caixas de laranja $(40,8 \mathrm{Kg} /$ caixa), correspondendo a $87 \%$ da produção brasileira e $30 \%$ da produção mundial (34).

Estas informações evidenciam a importância da citricultura paulista, colocando o Estado em primeiro lugar mundial na produção de laranja e de suco concentrado e; como maior exportador internacional de suco concentrado e farelo de polpa cítrica para alimentação animal. 


\subsection{Clorose Variegada dos Citros (CVC)}

\section{I.2.1. Histórico}

A produção brasileira de citros tem aumentado nos últimos anos devido à expansão da lavoura principalmente pelo Estado de São Paulo. A produtividade, entretanto, continua baixa quando comparada à americana: 2,0 caixas/árvore/ano no Brasil e 6,0 caixas/ árvore/ano na Flórida. As principais razões dessa baixa produtividade têm sido doenças, déficit hídrico e de fatores nutricionais (34).

Há duas ameaças simultâneas a serem consideradas quanto a propagação de doenças nos citros. A primeira, óbvia, é a destruição direta por conta da praga; a outra, indireta, é a desistência dos produtores rurais, o abandono da cultura reduz a taxa de renovação das plantas, ficam as mais velhas e o sistema torna-se menos produtivo.

Várias doenças afetam a cultura de citros. $\mathrm{Na}$ verdade, há mais de 60 anos, os produtores paulistas convivem com graves problemas fitossanitários que, por várias vezes dizimaram pomares. $\mathrm{Na}$ década de 30 , a gomose causada por fungos que atacam o sistema radicular da planta devastou a produção; nos anos 40 foi a vez da "tristeza dos citros" provocada por vírus provocando a morte de 12 milhões de plantas. $\mathrm{Na}$ década de 50, o exocorte colocou novamente em risco a produção, nos anos 60 apareceu o cancro cítrico, erradicando centenas de pomares. Os anos 70 vieram com o "declínio dos citros"; finalmente, nos últimos dez anos, a clorose variegada dos citros (CVC) tornou-se o principal problema da citricultura brasileira (42).

A CVC foi relatada primeiramente em 1987 nos estados de São Paulo e Minas Gerais, afetando todas as variedades comerciais de laranja. (75). Inicialmente identificada em pomares de Colina, município do centro-oeste do Estado de São Paulo, na região de Bebedouro, a doença, de fácil transmissão, espalhou-se rapidamente. Em apenas alguns anos já estava presente em $83 \%$ da principal área de citricultura do estado, tornando-se amplamente distribuída nas regiões de cultura de citros do Brasil.

Pesquisas realizadas demonstraram que, em 1992, 64\% dos pomares havia menos de uma árvore apresentando sintomas detectáveis e já, em 1996, foram 
encontrados plantas, com idade entre 3 e 5 anos, com sintomas severos em $88 \%$ dos pomares (Tabela 01).

Tabela 01:Cronologia da CVC no Brasil

\begin{tabular}{|c|c|}
\hline 1987 & Encontrado CVC nos Estados de São Paulo e Minas Gerais. \\
\hline Set.1988 & $\begin{array}{l}\text { Determinação das desordens nutricionais nas plantas de citros } \\
\text { afetadas pelo CVC: deficiências em zinco e potássio. }\end{array}$ \\
\hline Jun.1989 & $\begin{array}{l}\text { Primeiros experimentos. Associação errônea da CVC com um } \\
\text { vírus. }\end{array}$ \\
\hline $1988-1989$ & Materiais enviados ao INRA semanalmente. \\
\hline Dez.1989 & $\begin{array}{l}\text { Encontrado bactérias similares à Xylella fastidiosa nos vasos de } \\
\text { xilema do material apresentando a doença. Corresponde ao primeiro } \\
\text { achado desta bactéria em plantas cítricas afetadas pela CVC. }\end{array}$ \\
\hline Ago.1990 & Primeiro isolamento da bactéria no Brasil. \\
\hline Dez.1990 & $\begin{array}{l}\text { Isolamento da bactéria na Flórida com auxílio do Laboratório } \\
\text { Bioquímico do Instituto Biológico. }\end{array}$ \\
\hline 1991 & Utilização de técnicas sorológicas para a detecção da bactéria. \\
\hline Ago.1992 & $\begin{array}{l}\text { Confirmação da presença da bactéria em plantas de cítros } \\
\text { sintomáticas por Chagas et al (1992). } \\
\text { Visita de um grupo especialista estrangeiro a convite de } \\
\text { FUNDECITRUS. }\end{array}$ \\
\hline 1993 & Primeiro levantamento da CVC em pomares paulistas. \\
\hline Fev.1993 & $\begin{array}{l}\text { Confirmação da relação bactéria-doença para a Xylella fastidiosa } \\
\text { pelo postulado de Koch. } \\
\text { Primeiros resultados mostrando o envolvimento de insetos na } \\
\text { transmissão da CVC. }\end{array}$ \\
\hline 1994 & Obtenção de anticorpos. \\
\hline 1995 & Primeiros achados de Xylella fastidiosa em café. \\
\hline 1996 & $\begin{array}{l}\text { CVC encontrado em outros estados brasileiros. } \\
\text { Determinação de três principais vetores para a transmissão da CVC } \\
\text { no Brasil. } \\
\text { Desenvolvimento de testes moleculares para a detecção da doença. }\end{array}$ \\
\hline
\end{tabular}




\section{I.2.2. Sintomas}

A sintomas de clorose variegada dos citros, que afeta todos os cultivares de laranja doce cultivadas (Pera, Hamlin, Natal, Valência Folha Murcha, Baianinha, Barão e outras), podem demorar mais de um ano para serem observados, incluem: manchas cloróticas amarelas na face superior das folhas, que correspondem a pontos marrom claros na face inferior ou em ambas as faces, progredindo para necrose marrom escura com o coalescimento das manchas (Figura 01); redução no tamanho da laranjeira, com a ocorrência de copa plana quando esta é infectada ainda jovem, ou redução da velocidade de crescimento devido aos efeitos sobre os ramos em desenvolvimento (40) (Figura 02). Os frutos são muito menores que os normais, com sabor muito ácido, de amadurecimento precoce, coloração amarela intensa com manchas marrons que podem vir a tomar toda sua superficie e extremamente duros, inviabilizando o consumo in natura dos frutos e a extração de suco pelas máquinas. (Figura 03).

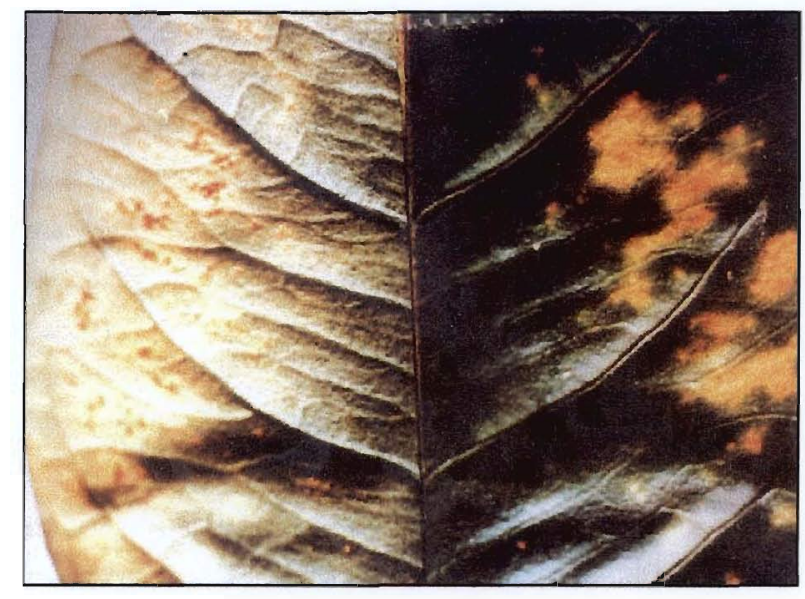

Rosseti, Gonzales and Donadio, 1998,

Figura 01: Sintomas foliares da Clorose Variegada dos citros (CVC). ̀̀ esquerda: a face inferior de uma folha infectada; à direita: a face superior da mesma folha (Fundecitros). 


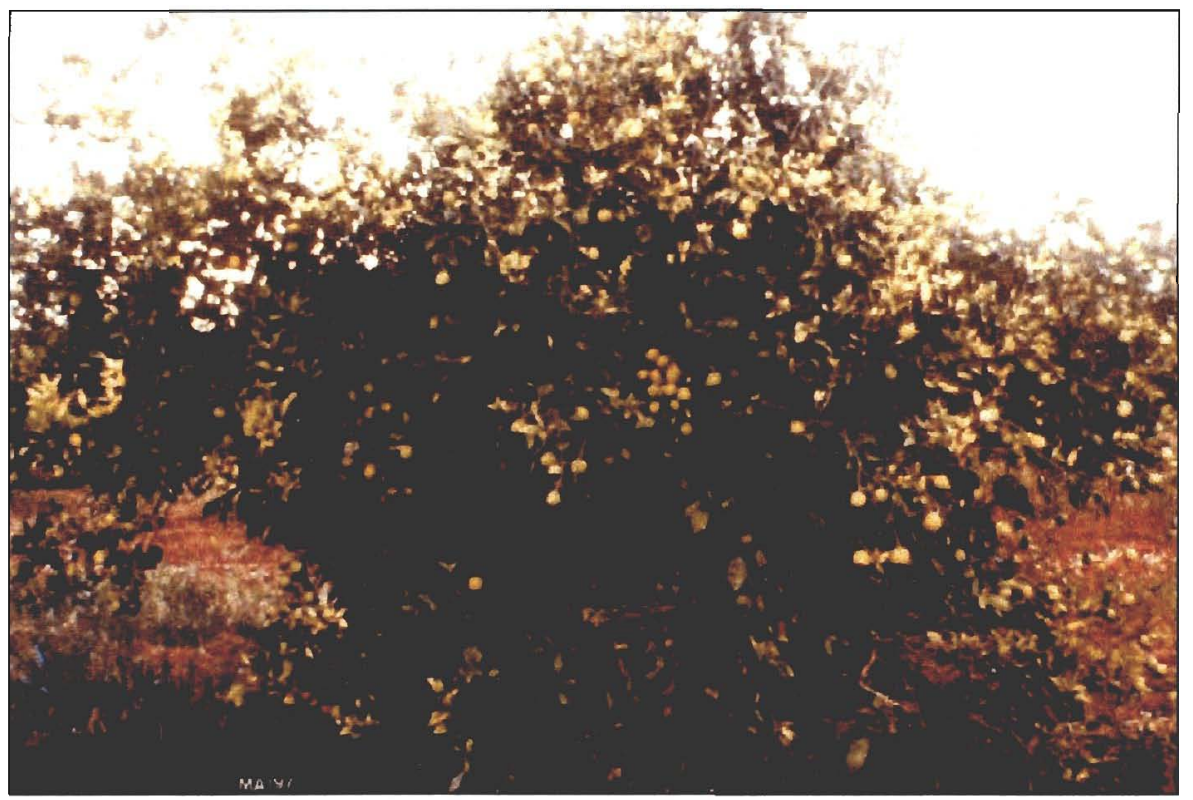

Rosseti, Gonzales and Donadio, 1998

Figura 02: Sintomas severos de Clorose Variegada dos Citros (CVC) em uma laranjeira "Pera" de três anos.

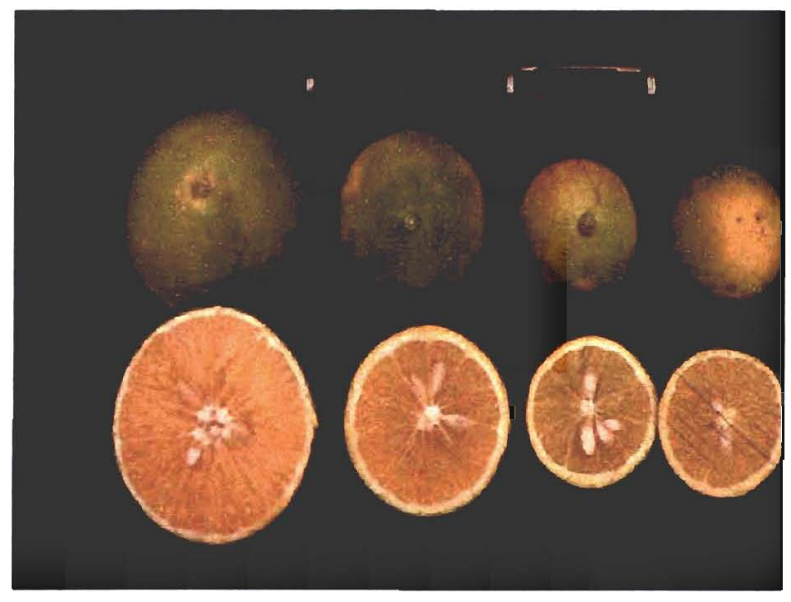

Machado, 2000

Figura 03: Comparação entre frutos provenientes de laranjeiras não infectadas pela CVC (primeira à esquerda) e infectadas (Fundecitros). 
O controle hoje exige a poda das árvores infectadas e a substituição por mudas seguramente sadias; hibridizações sexuais e a seleção de variedades tolerantes ou resistentes através da seleção massal em pomares ou em coleções de germoplasma têm sido empregados para se evitar a disseminação da doença.

\section{I.3. Hipóteses do agente causal da CVC}

Desde o início, hipóteses foram levantadas e investigadas por cientistas brasileiros envolvidos no estudo da CVC. Tais hipóteses são relatadas abaixo:

- Provável infecção viral. Alguns experimentos foram realizados entre 1987 e 1988 mas como as plantas não foram protegidas, nenhuma conclusão foi retirada e os dados não foram publicados

- Em 1989, um dos primeiros experimentos considerando os efeitos nutricionais como causa da CVC baseando-se em algumas características da doença foram publicados por Vitti et al. (72).

- As desordens nutricionais poderiam ser a causa da doença por propiciar as condições de desenvolvimento do patógeno que por sua vez poderiam induzir os sintomas de falta de molibdênio (11).

- Muitos dos sintomas observados mostraram aspectos fisiológicos, tais como toxicidade produzida por um excesso de herbicidas (07).

- Desordens nutricionais $(\mathbf{5 7}, \mathbf{5 8})$.

Os materiais coletados com sintomas de CVC eram periodicamente enviados ao laboratório do INRA (Institute National de Recherches Agronomiques) na França para serem analizados.

Em um material analizado por tal instituto foi detectado, por microscopia eletrônica, um vaso de xilema absolutamente cheio de bactérias similares à Xylella fastidiosa. Os testes para confirmação do postulado de Koch foram realizados, relacionando finalmente a bactéria como sendo a causadora da Clorose Variegada dos Citros (09). 


\section{I.4. Xylella fastidiosa}

\section{I.4.1. Taxonomia}

Em 1973, as bactérias classificadas como limitadas ao xilema (XLB- xylemlimited bacterium) foram associadas à doença de Pierce, em videira $(25,26)$, sendo então descritas como "rickettsia-like", devido às suas similaridades morfológicas e ultraestruturais com membros da familia Rickettsiaceae $(25,33)$.

A utilização do meio de cultura desenvolvido para o cultivo de Rochalimaea quintana (uma rickettsiae) propiciou o isolamento efetivo da bactéria causadora da doença de Pierce. Os requerimentos no inseto vetor e a preferência por ácidos orgânicos à dextrose também se mostraram semelhantes nas bactérias comparadas (13). Entretanto, em dois estudos de composição e tamanho de DNA das bactérias "rickettsiae-like", foram encontrados 49,5-53,1\% mol C+G (citosina + guanina) e um tamanho de genoma de 1,92 a $2,42 \mathrm{Mb}(46,75)$; enquanto que na $R$. quintana o valor encontrado foi de $38,5 \% \mathrm{~mol} \mathrm{C}+\mathrm{G}$. Concluiu-se que, embora houvesse muitas propriedades comuns entre as bactérias, elas eram geneticamente diferentes, sendo então não mais denominadas de "rickettsiae-like" mas sim de bactérias fastidiosas limitadas ao xilema (XLB).

Dentro deste novo grupo XLB, os estudos feitos por Kamper et al (46) com 5 cepas, demonstraram a impossibilidade de distinção em nível de espécie devido à elevada homologia de DNA (75-100\%) determinada por hibridizações. (32,68). Os autores consideraram que a homologia de DNA (75\%) entre a cepa causadora da doença de Pierce e a causadora da escaldadura foliar em amexeiras era baixa $o$ suficiente para sugerir uma distinção em nível varietal e, possivelmente, de subespécie. Wells et al (75) também encontraram em experimentos de hibridização, alta relação entre as cepas e, juntamente com o suporte de dados sorológicos e de análise de ácidos graxos, concluíram que as XLB constituíam um grupo homogêneo $(32,68)$.

Análises de rRNA 16S demonstraram similaridades entre cepas XLB e outras bactérias, sugerindo que aquelas pertenciam ao subgrupo das Eubactérias, que incluem o gênero Xanthomonas. Entretanto, as XLB diferem-se suficientemente fenotipica e genotipicamente para caracterizarem gêneros diferentes. Wells et al (75) 
propôs então o nome Xylella fastidiosa para estabelecer um novo gênero com uma única espécie incluindo todas as cepas de bactérias gram-negativas fastidiosas limitadas ao xilema.

Embora todas as cepas de Xylella tenham sido classificadas dentro de uma só espécie, há variabilidade suficiente para que haja uma separação taxonômica em subespécies. Todas as cepas de Xylella necessitam de um determinado meio para seu crescimento, mas podem ser separadas em dois grupos distintos baseados em diferentes necessidades nutricionais: o grupo a qual pertence a cepa causadora da doença de Pierce e o grupo a que pertence a cepa causadora da má formação de pêssegos. Cepas provenientes de videira, amendoeira, olmo e amoreira possuem tempos de duplicação menor $(0,5$ - 1,6 dias) quando comparados às cepas que ocorrem em pessegueiro e ameixeiras ( 2 dias). A distinção entre as cepas porém não é

trivial; testes sorológicos, tais como difusão em gel, imunofluorescência e ELISA (enzyme-linked immunosorbent assay) têm falhado em distinguir as cepas de Xylella fastiosa na maioria dos casos $(\mathbf{1 2}, \mathbf{1 3}, \mathbf{2 2})$.

\section{I.4.2. Morfologia}

Análises de microscopia eletrônica associaram a bactéria Xylella fastidiosa como a causadora de CVC em $1992(33,75)$. Esta constitui espécie única do gênero Xylella, grupo Xanthomonas, família Lysobacteriaceae, ordem Lysobacteriales, subdivisão Gama das Eubactérias.

É uma bactéria gram-negativa sistêmica (limitada aos vasos do xilema) de formato cilíndrico (bastonete), parede celular bem definida e ondulada, não flagelada, não formadora de esporos, estritamente aeróbia, não fermentativa, apigmentada (33), possuindo diâmetro de 0,3 a $0,5 \mu \mathrm{m}$ e de 1,0 a 5,0 $\mu \mathrm{m}$ em comprimento, contendo $51 \%$ mol de $\mathrm{C}+\mathrm{G}$ e sensibilidade à tetraciclina (Figura 04). 


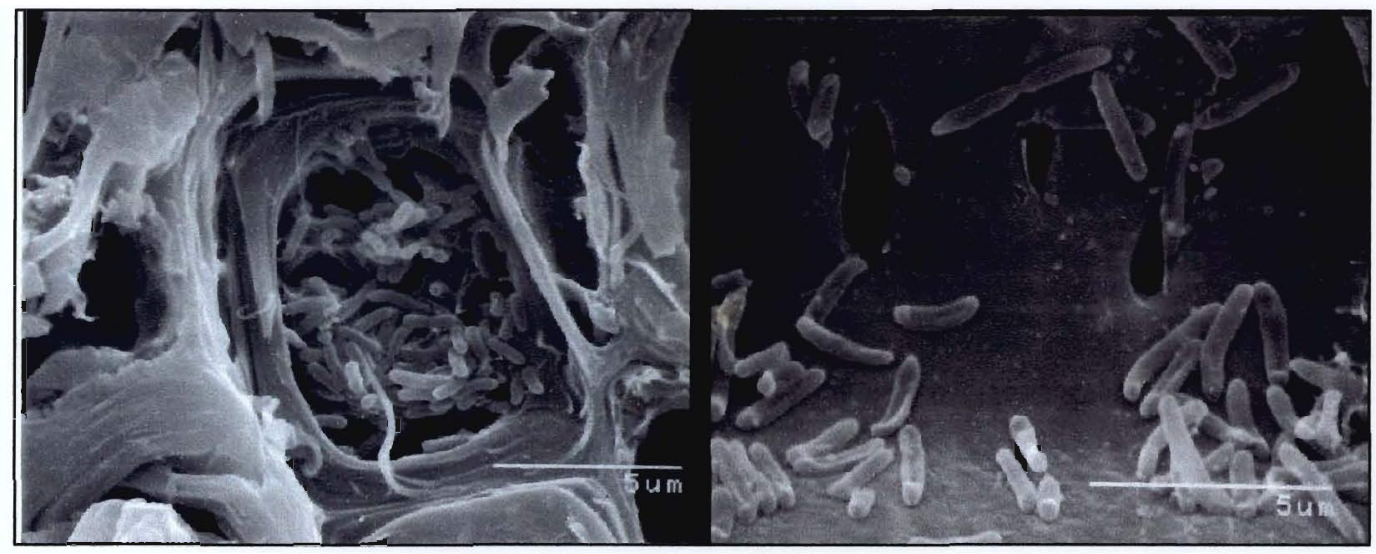

Machado, 2000

Figura 04: Micrografias eletrônica de Xylella fastidiosa no vaso de xilema em citros. (Fundecitros).

Crescendo bem a temperatura de 20 a $25^{\circ} \mathrm{C}$ e pH 6,7 a 7,0 , este organismo fastidioso requer ainda um meio complexo de crescimento, ocorrendo apenas no xilema dos pecíolos, nervuras foliares e do tronco das plantas infectadas e dificilmente isoladas por métodos bacteriológicos padrão.

A bactéria pode ser ainda encontrada nos elementos traqueais e esôfago de insetos de diversas classes, sugerindo que a bactéria é transmitida do esôfago pela egestão durante a alimentação do inseto infectado. Estes insetos quando adultos podem transmitir a bactéria imediatamente após adquirí-la e continuar a transmití-la eficientemente por toda sua vida, o que pode levar muitos meses $(\mathbf{2 1 , 6 6 , 7 0 )}$.

\section{I.4.3. Transmissão}

A Xylella fastidiosa é transmitida por insetos vetores, dependendo deles para sua disseminação natural. O entendimento do mecanismo de transmissão se torna importante na identificação dos vetores e avaliação dos cutivos resistentes e dos dados epidemiológico e de campo de ação (68).

Inicialmente, todos os insetos sugadores que se alimentam principalmente do xilema seriam vetores em potencial, mas as espécies podem variar em sua eficiência e competência de transmissão (67). Geralmente os insetos vetores conhecidos de Xylella fastidiosa pertencem à ordem Hemiptera, subordem Homoptera, família Cercopidae, representando as denominadas cigarrinhas (64). Suas ninfas são mais 
facilmente encontradas mas são pouco vistas por causa da espessa massa de espuma que as envolve. Estas massas são comumente vistas em plantas herbáceas que fornecem alimento para ninfas e adultos.

No Brasil, as espécies mais importantes relacionadas à propagação da doença por serem mais frequentemente encontradas em plantas cítricas são: Acrogonia terminalis, Dilobopterus costalimai, Oncometopia fascialis (Figura 05) (05). Além disso, novas espécies têm sido identificadas como vetores e outras ainda são consideradas como vetores em potencial (28).

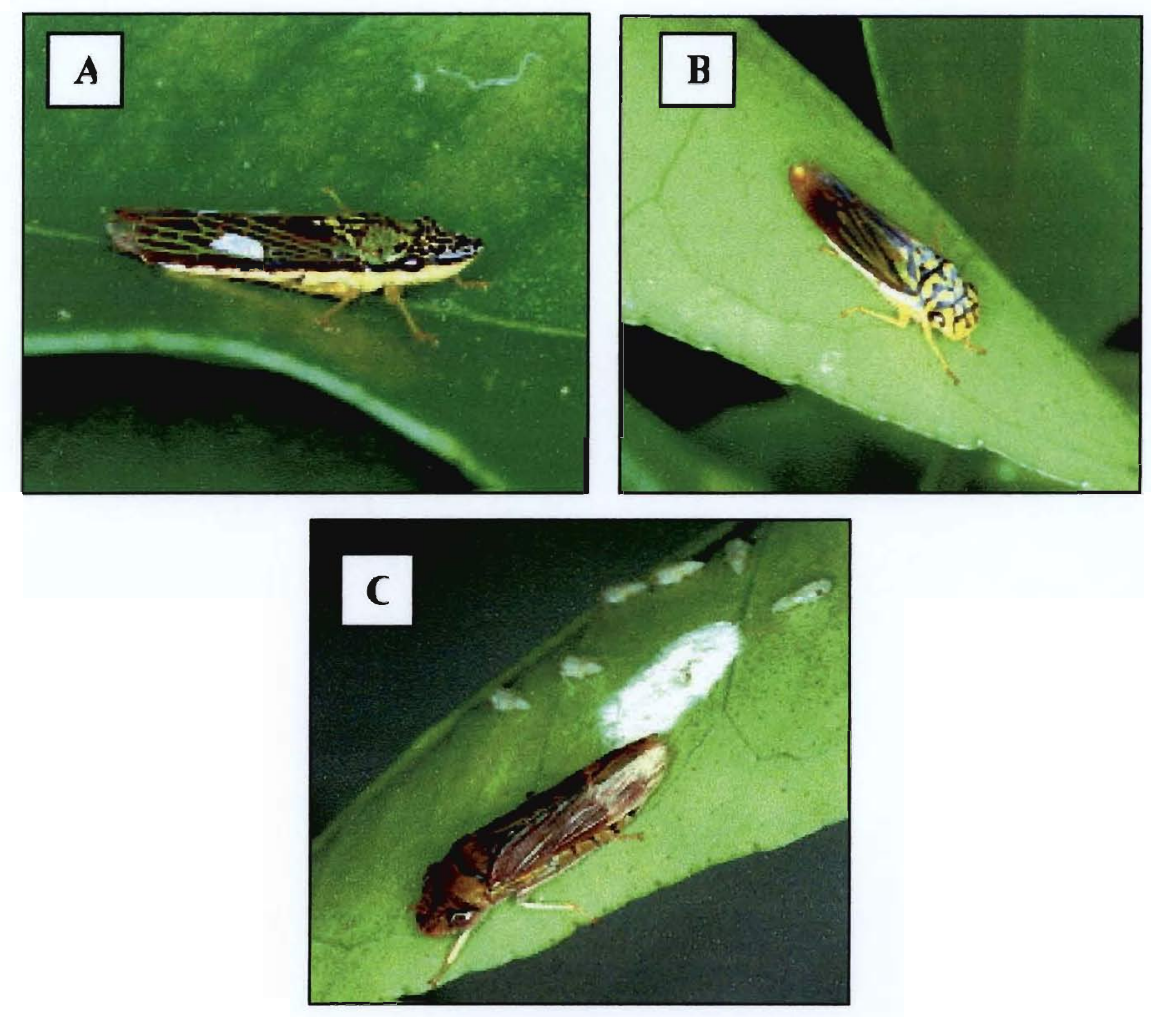

Brlansky, Timmer, French and McCoy, 1983

Figura 05: Insetos vetores mais comumente encontrados no Brasil. A. Acrogonia terminalis. B. Dilobopterus costalimai. C Oncometopia fascialis (Fundecitros).

Quando o vetor adquire as bactérias de uma planta infectada, ele se torna imediatamente capaz de transmití-la a outras plantas eficientemente até o final de sua vida (o que pode durar meses). Entretanto, Purcell \& Finlay (64) observaram que ninfas da doença de Pierce perdiam sua infectividade após sua ecdise, sugerindo que a 
bactéria estaria colonizada nos dutos de alimentação (foregut) sendo perdida nesta fase de transição. Mais especificamente, a Xylella fastidiosa foi observada colonizando a bomba cibarial (cibarium) e o revestimento do esôfago (precibarium) dos insetos na região pré-ventral, sugerindo que a multiplicação da bactéria seja propagativa e não circulativa (Figura 06).

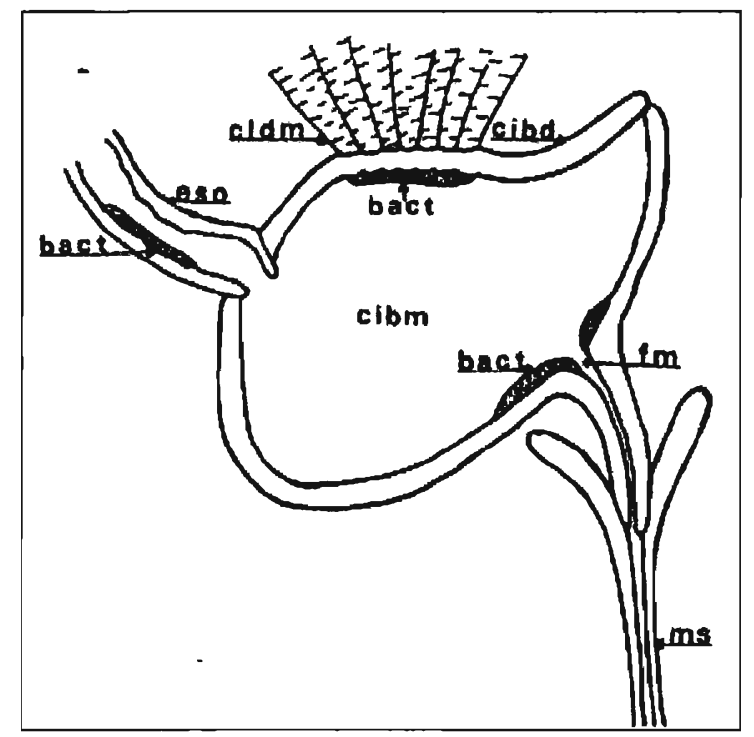

Purcell and Finlay, 1979

Figura 06: Esquema de um corte sagital do duto de alimentação de Graphocephala atropunctata mostrando a localização de Xylella fastidiosa (65). ms: estiletes maxilares; fm: meato alimentar; cibm: cibarium; bact: agregação bacteriana; cldm: músculos; cibd: diafrágma cibarial, eso: esôfago.

Os insetos que se alimentam da seiva bruta do xilema sobrevivem e se reproduzem no que provavelmente é a mais diluída fonte de alimento de qualquer grupo animal terrestre (68). Consequentemente, esses insetos ingerem quantidades de seiva que, muitas vezes, é muito maior que seu volume corporal, possuindo alta eficiência digestiva (acima de $99 \%$ da maioria dos aminoácidos).

Outro obstáculo é a forte tensão negativa da seiva bruta em relação à atmosfera, o que aumenta substancialmente a energia necessária para extraí-la do xilema das plantas. O cibarium (câmara de ingestão) torna-se então um microambiente altamente seletivo, uma vez que possui uma baixa concentração de 
nutrientes e alta velocidade de fluxo. A pressão negativa do xilema pode momentaneamente reverter o fluxo dentro do canal alimentício, desalojando células bacterianas que são então egeridas através do canal para a planta, infectando-a.

\section{I.4.4. Características do habitat}

A Xylella fastidiosa localiza-se em células ou tecidos específicos formando agregados principalmente nos elementos traqueais, traqueídes ou vasos de seus hospedeiros, podendo ser ocasionalmente encontrada nos espaços intercelulares do xilema.

A seiva bruta providencia um meio ambiente nutricional diluído contendo, entretanto, uma grande variedade de nutrientes essenciais. A quantidade e composição destes nutrientes variam com o período do dia, estação do ano, localização, idade e estado de saúde da planta. Constitui-se de diversos aminoácidos, ácidos orgânicos e íons inorgânicos. A Glutamina e asparagina ocorrem em concentrações desproporcionalmente elevadas, consistente com o meio de crescimento necessário para crescer a bactéria.

Atualmente existem diversos meios descritos para o seu isolamento, dentre eles: PD2 (13); PD3; PW (15), CS-20 (08) e XF-26 (10), o único totalmente definido quimicamente. Com a formulação do meio XF-26, os pesquisadores puderam aprofundar os estudos sobre os elementos essenciais no desenvolvimento dessa bactéria e observaram que para os três isolados testados, dois provenientes de videira e um de Prunus amydgalus, os componentes necessários conduziram sempre a uma mesma resposta quando alterados na formulação. Um primeiro fator observado foi que a presença dos sais inorgânicos $\mathrm{MgSO}_{4} .7 \mathrm{H}_{2} \mathrm{O}$ e $\mathrm{KH}_{2} \mathrm{PO}_{4}$ são comuns para os meios XF-26, CS-20 e PD2, enquanto os meios XF-26 e CS-20 contém em adição $\left(\mathrm{NH}_{4}\right) 2 \mathrm{HPO}_{4}$ e , PD2 inclui $\mathrm{K}_{2} \mathrm{HPO}_{4}$. Os meios XF-26 e PD2 contém Citrato trissódico e succinato dissódico, como fontes de energia, sendo que em XF-26 quando ambos ácidos carboxílicos são excluídos, não se observa o desenvolvimento das colônias, o que sugere que esta bactéria utiliza o ciclo de Krebs como rota de energia. Foi também verificada a necessidade dos 17 aminoácidos componentes do meio concluindo que a supressão de um deles reduz em $75 \%$ o crescimento no isolamento ou até inviabiliza o crescimento em repicagens sucessivas. $\mathrm{O}$ suplemento em Ferro, 
cloreto de Hemin em CS-20, PW e PD2 foi observado como tendo papel numa melhor promoção do crescimento, pois sua supressão não comprometeu o desenvolvimento de colônias de dois isolados oriundos de hospedeiros diferentes, suportando mais de 15 repicagens sem perder sua viabilidade.

Quando a cepa bacteriana responsável pela doença de Pierce foi experiamentalmente inoculada em videiras susceptíveis, a população bacteriana no xilema declinou nos três a cinco dias, ou seja, pereceram no primeiro estágio de colonização. A questão interessante não está em descobrir o porquê de tantas bactérias terem morrido mas sim quais mecanismos especiais a Xylella fastidiosa possui para permitir a ela uma sobrevivência neste nicho ecológico único.

\section{I.4.5. Patogenicidade}

Os principais sintomas observados decorrentes da infecção pela Xylella fastidiosa, como necrose marginal das folhas e a diminuição do crescimento principlamente na primavera, entre outros, sugerem a disfunção no sistema de condução de água pela planta $(32,68)$.

A hipótese sobre o mecanismo de patogenicidade mais aceita evidencia a produção de stress de água devido à oclusões vasculares causadas por agregados bacterianos (40), estando então relacionada à capacidade de multiplicação e habilidade de movimentação sistemática deste patógeno de um vaso para outro nos nos vasos do xilema através das membranas pontuadas $(32,68)$.

Os agregados bacterianos parecem ser mantidos pelas fibras extracelulares produzidas pela bactéria, sendo caracterizadas como fimbrias, microfibrilas eletro densas. São mais abundantes nas extremidades das bactérias, assemelhando-se à massa entrelaçada de fibras de polissacarídeos que se estende da superfície de diversas outras bactérias, denominada "glicocálix". Ao glicocálix estão relacionadas funções de sobrevivência e patogenicidade $(32,68)$.

Primeiramente, a adesão entre bactérias e destas ao hospedeiro em um ambiente favorável formando agregados pode conservar e concentrar enzimas digestivas produzidas pelas bactérias que por sua vez são direcionadas contra o tecido hospeiro. As fibras de polissacarídeo são carregadas negativamente, podendo funcionar similarmente à uma resina de troca iônica, servindo como um reservatório 
nutricional, ligando nutrientes iônicos no agregado bacteriano e tornando-os disponíveis às células e ao meio nutricional diluído. Essa rede de fibras pode funcionar ainda como uma proteção às defesas do hospedeiro.

Evidências sugerem que cepas avirulentas são capazes de se multiplicar como as virulentas logo após a inoculação em videiras mas não são capazes de se mover sistematicamente (24) para fora da região de entrenós inoculada.

A propagação da bactéria pelo sistema condutor (no caso, o xilema) ainda não esta elucidada: Propõe-se que a bactéria produza enzimas que degradam as membranas das células do vaso condutor. No caso da denominada doença de Pierce, ocorre um fluxo restrito de água e nutrientes devido a uma oclusão parcial ou completa de elementos condutores por "plugs" bacterianos, havendo também evidência de que toxinas capazes de induzir sintomas foliares são produzidas por Xylella fastidiosa (29).

\section{I.4.6. Deteç̧ão}

A sensibilidade e confiança dos métodos de detecção em plantas e insetos possuem importantes implicações com respeito à pesquisa e entendimento dos patógenos.

Existem alguns métodos utilizados para deteç̧ão de Xylella fastidiosa como Western Blot (04, 30, 56, 61), DIBA (Dot immuno-binding assay) (49, 30, 56, 61), ELISA (Enzyme linked immunosorbent assay) $(35,52,53,61)$ e PCR $(10,50,59,63)$ sendo os principais sorologia e PCR, cada um com uma vantagem em relação ao outro.

Os métodos sorológicos (ELISA/ DIBA e Imunofluorescência) tem como vantagem uma maior rapidez na preparação do material mas detectam aproximadamente 100 bactérias $/ \mathrm{mL}$ (56), sendo consideradas técnicas de baixa resolução. O teste ELISA ainda possui os inconvenientes de falso positivo e da utilização de antissoros policlonais, tendo sido no entanto utilizado em diversos trabalhos (52, 56, 61). O teste DIBA, apesar de ser específico para espécie e considerado um dos métodos mais seguros (51), não permite a diferenciação a nível infra-específico. A vantagem do DIBA e Western Blot é que pode-se ter uma idéia da concentração da bactéria nos tecidos, observando-se a intensidade da reação. 


\section{I.5. Projeto Genoma Xylella fastidiosa}

Com a rápida evolução das técnicas de biologia molecular, surgiu a idéia do seqüenciamento completo de um genoma no país. Com base em todas as características da citricultura paulista indicou-se em maio de 1997 um potencial alvo para o seqüenciamento: a bactéria fitopatogênica Xylella fastidiosa.

Em novembro do mesmo ano ocorreu a seleção pela FAPESP dos participantes, estando nosso laboratório entre os 33 escolhidos (32 laboratórios de seqüenciamento e 1 laboratório de bioinformática) (Apêndice B), organizados em uma rede virtual denominada ONSA (Organization for Nucleotide Sequence Analysis).

Financiado pela FAPESP (Fundação de Amparo a Pesquisa do Estado de São Paulo) e pelo FUNDECITROS (Fundo de Defesa da Citricultura de São Paulo), o projeto teve como principal objetivo o seqüenciamento total do genoma do fitopatógeno Xylella fastidiosa, causador da doença clorose variegada dos citros (CVC). Além disso, a utilização das mais modernas técnicas de biologia molecular propiciou o treinamento de diversas pessoas envolvidas no projeto que, a partir dele, podem utilizar esse aprendizado e o seqüenciador automático adquirido (ABI 377) para o desenvolvimento de pesquisas ligadas às linhas originais de trabalho dos laboratórios.

A estratégia principal foi a de seqüenciamento, por cada laboratório do projeto, de insertos de DNA de Xylella de aproximadamente 40 kilobases, clonados em cosmídeos. Uma biblioteca de cosmídeos foi construída pela Dra. Anete Pereira (UNICAMP) em colaboração com o grupo do Dr. Hoheisel (Alemanha), e os clones desta biblioteca foram selecionados para seqüenciamento por hibridização e mapeamento do genoma da bactéria (23). Os cosmídeos selecionados para seqüenciamento tentaram representar a menor redundância possível (Apêndice C).

Em seguida foram seqüenciados em larga escala os clones provenientes das bibliotecas randômicas "shotgun", ou seja, de insertos gerados por fragmentação mecânica randômica do DNA genômico da bactéria, e clonagem dos insertos de 0,7 a 1,5 kilobases em plasmídeos (Apêndice D e E).

Estratégias "secundárias" foram estabelecidas no decorrer do projeto para a cobertura total do genoma em regiões não cobertas pelas bibliotecas de cosmídeos ou 
de "shotgun". Diversas foram as alternativas para a obtenção deste propósito, que serão discutidas no decorrer desta tese.

Outro objetivo do trabaho de cada grupo foi a anotação deste genoma. Uma anotação consiste em predições de função para proteínas provavelmente codificadas pelos genes e encontradas no organismo. Anotações foram realizadas por diferentes laboratórios e em diferentes etapas, sendo importantes para a maior compreensão dos mecanismos presentes em Xylella fastidiosa. 


\section{Objetivos}

O objetivo inicial do trabalho era o seqüenciamento total de um cosmídeo e o seqüenciamento de um certo número de clones das bibliotecas "shotgun", para a confirmação da montagem dos contigs e para a determinação de partes do genoma não cobertos pelos cosmídeos, num total de 50.000 bases. A subestimação do tamanho do genoma e os rumos tomados no decorrer do projeto fizeram com que as metas e objetivos de cada grupo individual fossem se adequando ao projeto global. $\mathrm{O}$ nosso laboratório, designado de $\mathrm{QV}$, foi responsável pelo seqüenciamento de 7 cosmídeos representando aproximadamente 270.000 bases do genoma da bactéria e clones provenientes de 7 bibliotecas de "shotgun" (aproximadamente 490.000 bases do genoma).

Com o objetivo de cobrir os "gaps" do genoma, o nosso grupo passou a participar de algumas das estratégias utilizadas para o fechamento dos mesmos "gaps", entre elas: o seqüenciamento total de um clone proveniente de uma biblioteca de "shotgun", seqüenciamento diretamente do genoma do fitopatógeno, e de clones provenientes do que foi chamada de biblioteca de "RDA", explicada no decorrer deste relatório.

Além disso, o laboratório também ficou responsável pela primeira etapa de anotação (predições de função para proteínas provavelmente encontradas no organismo) de aproximadamente 290 ORFs (Open reading frames ou fases abertas de leitura). 


\section{Materiais e Métodos}

\section{III.1.Cepas bacterianas utilizadas}

Foram utilizadas as seguintes cepas de Escherichia coli:

- DH5 $\alpha$ (Gibco, BRL): endA1 recA1 deoR thi-1 supE44 $\lambda$-gyrA96 FhsdR17(rk- mk+) $\phi 80$ dlacZ $\Delta$ M15 $\Delta$ (lacZYA-argF)U169.(19)

- DH10Bß (Gibco, BRL): endA1 recA1 relA1 deoR thi-1 supE44 $\lambda$-gyrA96 merA F ${ }^{-} \Delta$ (mrr-hsdRMS-mcrBC) $\phi 80$ dlacZ $\Delta$ M15 $\Delta$ (lacZYA-argF) U169. (55)

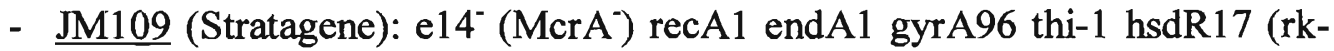

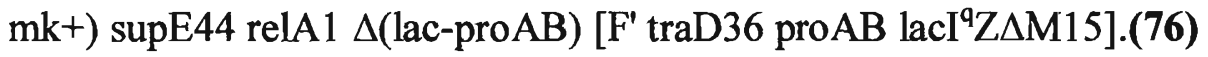

- Top10 (Invitrogene): $F^{\prime}$ mcrA $\Delta$ (mrr-hsdRMS-mcrBC) $\phi 80$ lacZ $\Delta M 15$ $\Delta$ lacX74 deoR recA1 araD139 $\Delta$ (ara-leu)7697 galU galK $\operatorname{rpsL}\left(\operatorname{Str}^{\mathrm{R}}\right)$ endA1 nupG.

- Xl1-blue MRF '® (Stratagene): $\Delta$ (mcrA) $183 \Delta$ (mcrCB-hsdSMR-mrr) 173 endA1 supE44 thi-1 $\operatorname{recA}$ gyrA96 relA1 lac $\left[\mathrm{F}^{\prime}\right.$ proAB lacI $^{\mathrm{q}} \mathrm{Z} \Delta \mathrm{M} 15 \operatorname{Tn} 10$ (Tet $\left.\left.^{\mathrm{r}}\right)\right]^{\mathrm{c}}$.(45)

\section{III.2. Vetores utilizados}

Foram utilizados os seguintes vetores:

- Lawrist4 (36)

- $\mathrm{pbSK}$

- pUC18

Os vetores Lawrist4 e pUC18 foram utilizados nas construções das bibliotecas de cosmídeo e shotgun respectivamente, não sendo utilizados em nosso laboratório.

Os vetores utilizados possuem suas extremidades defosforiladas para evitar a sua re-ligação. Para a produção do vetor pbSK utilizado nas produções de subbibliotecas plasmidiais foi realizado primeiramente um tratamento com a enzima de restrição EcoR V, onde aproximadamente $5 \mu \mathrm{g}$ do vetor intacto foi digerido com $20 \mathrm{U}$ desta enzima em um volume final de $100 \mu \mathrm{L}$; incubado por 1 hora à $37^{\circ} \mathrm{C}$. O DNA foi precipitado com adição de Acetato de sódio 3M, pH 5,2 (1/10 vol/vol) e etanol 100\% (2,5X vol) e lavado com $500 \mu \mathrm{L}$ de etanol $70 \%$, o pellet ressuspenso em um volume de $20 \mu \mathrm{L}$ de Tris- $\mathrm{Cl} 10 \mathrm{mM}$ pH 8,0. 
A defosforilação desse vetor foi realizada com os $5 \mu \mathrm{g}$ de DNA previamente digeridos e 10U da enzima Calf intestinal phosphatase (CIP) em um volume final de reação de $50 \mu \mathrm{L}$. A incubação foi de 30 minutos à $37^{\circ} \mathrm{C}$, a extração, precipitação e lavagem foram realizadas como descrito acima e o pellet foi ressuspenso em $20 \mu \mathrm{L}$ de água destilada e deionizada (milliQ) autoclavada.

\section{III.3. "Primers" utilizados}

Foram utilizados os seguintes "primers":

- $\quad$-40M13: 5' GTT GGC CCA GTC ACG AC 3'

- -50M13: 5' TTG TGA AGC GGA TAA CAA T 3'

- LudF: 5' GCG CAG GGT TTT CCC AGT CAC GAC 3'

- LudR: 5' TTT CAC ACA GGA AAC AGC TAT GAC 3'

- $\underline{T}_{3}: 5^{\prime}$ ATT AAC CCT CAT AAA GGG A 3'

- $\underline{T}_{7}:$ 5' TAA TAC GAC TAC TAG TG 3'

Além destes primers acima, presentes nas regiões flanqueadoras dos sítios de clonagem dos vetores utilizados, foram utilizados primers específicos para regiões internas dos insertos de cosmídeos ou plasmídeos, para a obtenção do fechamento destes ou na melhoria de qualidade de certas regiões. (Apêndice F). 


\section{III.4.Seqüenciamento do genoma de Xylella fastidiosa.}

Diversas estratégias foram adotadas para a determinação da sequência nucleotídica completa do fitopatógeno Xylella fastidiosa, sendo as principais caracterizadas pelo seqüenciamento de clones provenientes das bibliotecas de cosmídeos e de bibliotecas randômicas (shotgun).

A biblioteca de cosmídeos foi feita na Alemanha pela Dra. Anete Pereira Souza no laboratório do Dr.Hoheisel, em Heidelberg, a partir do DNA total da bactéria (23). A biblioteca foi feita através de digestão parcial do DNA total com a enzima de restrição MboI e clonagem dos fragmentos obtidos em sítio de BamHI do vetor Lawrist4 (36).

As bibliotecas de "shotgun" foram necessárias para o auxílio no fechamento dos "gaps" encontrados, mostrando-se uma estratégia adequada para tal fim, além de contribuir para a confirmação da montagem dos contigs. Diversas bibliotecas de "shotgun" genômico de Xylella fastidiosa foram feitas, estando listadas no Apêndice D.

\section{III.4.1. Seqüenciamento de clones das bibliotecas randômicas} 00 e 03.

Inicialmente foram distribuídos aos laboratórios envolvidos os clones randômicos das bibliotecas 00 e 03. Estas bibliotecas, preparadas por Joaquim Machado e Frédéric Laigret (Laboratoire de Biologie Cellulaire et Moléculaire, INRA, Villenave d'Ornon), foram geradas por digestão total do DNA do genoma por enzima Nsil (biblioteca 00) ou MunI (biblioteca 03). Os fragmentos foram clonados em plasmídio pBS+/PstI (biblioteca 00) ou pBS+/EcoI (biblioteca 03) em Escherichia coli XL1-blue KAN@.

Nosso grupo (QV) recebeu um total de 3 placas provenientes dessas bibliotecas, seqüenciando 162 clones. Para a obtenção do template necessário, foi utilizada técnica de obtenção de plasmídeos por lise alcalina modificada (69), modificada pelo Prof. Dr. Marcelo Bento Soares (University of Iowa, EUA) (Apêndice L.1). 
Obtidos os plasmídeos contendo o DNA a ser seqüenciado, foram realizadas reações de extensão para a incorporação dos ddNTPs (dideóxi-nucleotideos) covalentemente ligados a agentes fluorescentes específicos para cada ddNTP.

Utilizou-se 400ng de DNA proveniente das minipreparações plasmidiais; 0,8 pmol dos primers - $40 \mathrm{M} 13$ ou $-50 \mathrm{M} 13 ; 4 \mu \mathrm{L}$ do reagente $\mathrm{ABI}$ Prism® ${ }^{\circledR}$ BigDye $^{\mathrm{TM}}$ Terminator Cycle Sequencing Ready Reaction Kit with AmpliTaq DNA Polymerase (Perkin-Elmer, EUA), completando-se o volume de $10 \mu \mathrm{L}$ com água destilada e deionizada (água milliQ), nas condições de termociclador abaixo descritas:

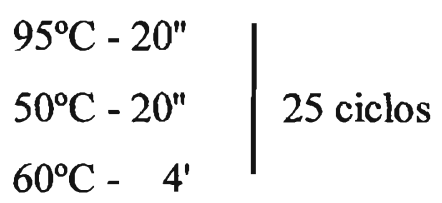

A precipitação foi realizada com $80 \mu \mathrm{L}$ de isopropanol $75 \%$; vortex breve; incubação de 15 minutos à temperatura ambiente e centrifugação de 20 minutos a $14.000 \mathrm{rpm}$. A lavagem do pellet foi feita com $250 \mu \mathrm{L}$ de isopropanol $75 \%$ com novo vortex e centrifugação por 5 minutos à $14.000 \mathrm{rpm}$. $O$ pellet ressuspenso no tampão apropriado (1 parte de $50 \mathrm{mg} / \mathrm{mL}$ Blue Dextran ${ }^{\circledR} 25 \mathrm{mM}$ de EDTA pH 8,0 para 5 partes de formamida deionizada) e denaturado a $92^{\circ} \mathrm{C}$ por 1 minuto em termociclador para ser "aplicado" em gel 5,5\% acrilamida (acrilamida/bisacrilamida Long Ranger ${ }^{\mathrm{TM}}$ $50 \%)$, tampão TBE (69) e uréia $0,36 \mathrm{~g} / \mathrm{mL}(5,0 \mathrm{~mol} / \mathrm{L})$.

\section{III.4.2. Construção das sub-bibliotecas de "shotgun"}

Todos os cosmídeos foram entregues em uma placa de cultura YT/Kanamicina $30 \mu \mathrm{g} / \mathrm{mL}$ contendo diversas colônias mas representando somente um clone da biblioteca de cosmídeo.

Para a verificação de possíveis contaminantes nessa placa, selecionou-se ao acaso 5 colônias isoladas e fez-se uma minipreparação plasmidial e posterior digestão com enzimas de restrição (normalmente EcoR I e Hind III) do DNA extraído. Não se constatando contaminação, um clone (entre as 5 pré-culturas existentes) é então selecionado para ser estocado em glicerol (40\% v/v final); também foi amplificada para se obter uma maior quantidade de DNA para o seu seqüenciamento total. Para a 
obtenção desta quantidade maior de DNA utilizou-se metodologia de maxipreparação plasmidial (kit QIAGEN).

O DNA obtido foi então clivado enzimaticamente (o que se demonstou ineficiente) ou por métodos físicos (sonicação ou nebulização). Para o primeiro cosmídeo recebido (07B03) foram testadas todas as metodologias mencionadas acima para ver qual seria mais adequada e reprodutível em nosso laboratório para os cosmídeos seguintes.

Pela metodologia enzimática, utilizada em especial para este cosmídeo 07B03, foram construídas duas sub-bibliotecas:

- Biblioteca Alu I: onde o DNA total do cosmídeo foi digerido com a enzima de restrição Alu I, sem seleção de tamanho de fragmento (todos ficando abaixo de 1,2 $\mathrm{Kb}$ ), clonados em sítio EcoR V do vetor pbSK.

- Biblioteca Sau3A I: onde o DNA total do cosmídeo foi digerido com a enzima de restrição Sau3A I, sem seleção de tamanho de fragmento (todos ficando abaixo de 1,5 Kb), clonados em sítio BamH I em vetor pbSK.

Outra metodologia testada e somente utilizada para este cosmídeo 07B03 foi a de fragmentação mecânica do DNA total por sonicação. Para tal metodologia foi utilizada e padronizada uma sonicação em "cup horn" de aproximadamente 100ng de DNA em 3 tempos de 4 segundos/cada. Os fragmentos de tamanhos entre 1,3 e 2,3 $\mathrm{Kb}$ foram selecionados, reparados em suas extremidades e clonados em vetor pbSK defosforidado em suas pontas blunt end geradas por digestão com a enzima EcoR V. A obtenção de tal biblioteca não foi conseguida e tal metodologia foi abandonada.

A metodologia de nebulização foi a que se mostrou mais eficiente e por isso adotada em preparações das sub-bibliotecas "shotgun" também dos demais cosmídeos.

Em tal metodologia utiliza-se aproximadamente $20 \mu \mathrm{g}$ de DNA proveniente de uma maxi preparação plasmidial (kit QIAGEN) e 30\% de glicerol em um volume final de $1 \mathrm{~mL}$, introduzidos em nebulizador comercial pré-esterelizado em água fervente por alguns segundos. O DNA é então nebulizado aplicando-se $0,6 \mathrm{kgf} / \mathrm{cm}^{2} \mathrm{de}$ pressão de gás nitrogênio, em 3 etapas de 40 segundos cada. A purificação foi feita com auxílio do kit QIAEX II Agarose Gel Extration e o DNA foi ressuspenso em um volume final de $120 \mu \mathrm{L}$ de Tris- $\mathrm{Cl} 10 \mathrm{mM}$ pH 8,0 (com uma concentração aproximada de $130 \mathrm{ng} / \mu \mathrm{L})$. 
Em seguida fez-se o tratamento do DNA nebulizado com $\mathrm{T}_{4}$ DNA polimerase, utilizou-se aproximadamente 2,6 $\mu \mathrm{g}$ de DNA, 0,2 $\mathrm{mM}$ de cada dNTP e $3 \mathrm{U}$ de enzima em um volume final de $100 \mu \mathrm{L}$. A incubação foi realizada à $15^{\circ} \mathrm{C}$ durante 2 horas. A amostra foi extraída com fenol:clorofórmio $(1: 1 \mathrm{v} / \mathrm{v})$, precipitada com adição de Acetato de sódio 3M, pH 5,2 (1/10 v/v) e etanol 100\% (2,5X vol) e lavada com 500 $\mu \mathrm{L}$ de etanol $70 \%$. O pellet foi ressuspenso em um volume de $20 \mu \mathrm{L}$ de Tris-Cl $10 \mathrm{mM} \mathrm{pH} \mathrm{8,0} \mathrm{(130ng/ \mu L).}$

Em seguida fez-se o reparo das extremidades para torná-las "blunt end", através de tratamento de 2,6 $\mathrm{gg}$ deste DNA com $20 \mathrm{U}$ de enzima Mung Bean nuclease, em um volume final de $100 \mu \mathrm{L}$. A incubação foi de 30 minutos à $37^{\circ} \mathrm{C}$. A extração, precipitação e lavagem foram realizadas como descrito acima. O pellet foi ressuspenso em um volume de $20 \mu \mathrm{L}$ de Tris- $\mathrm{Cl} 10 \mathrm{mM} \mathrm{pH} \mathrm{8,0}$, ficando em uma concentração final de $130 \mathrm{ng} / \mathrm{mL}$.

As amostras foram então aplicadas em um gel preparativo com a finalidade de seleção dos tamanhos desejados. Os fragmentos gerados pelo processo de nebulização, tal como os fragmentos gerados pelo processo de sonicação, foram selecionados entre 1,3 e 2,3 Kb, retirados do gel através da utilização de Kit QIAEX II Agarose Gel Extration e precipitados com adição de etanol 100\% (2,5X vol) e acetato de sódio $3 \mathrm{M} \mathrm{pH} \mathrm{5,2} \mathrm{(1/10} \mathrm{v/v).} \mathrm{Estes} \mathrm{fragmentos} \mathrm{foram} \mathrm{então} \mathrm{ligados} \mathrm{a} \mathrm{um}$ vetor pbSK defosforilado em suas pontas blunt end geradas a partir de digestão com enzima EcoRV.

Após a ligação, bactérias competentes XL1-blue MRF ' ou Top10 (Apêndice L.2) produzidas em nosso laboratório foram transformadas, através de eletroporação (BioRad Gene Pulser $\circledast$ Cuvette de $0,2 \mathrm{~cm}$ ) utilizando 2,5 volts, $125 \mu \mathrm{F}$ de capacitância e corrente de $1 \mathrm{~A}$ (âmpere). Foram então selecionados os clones contendo plasmídeos com inserto, após plaqueamento em meio sólido LB-ágar contendo $50 \mu \mathrm{g} / \mathrm{mL}$ do antibiótico ampicilina, IPTG (isopropiltio- $\beta$-galactopironosídeo) e Xgal (5-bromo-4-cloro-indolil-galactopirnosídeo) $(69,74)$.

As colónias brancas, contendo plasmídio recombinante, foram repicadas em placas 96 wells de fundo redondo contendo meio LB e ampicilina $(100 \mu \mathrm{g} / \mathrm{mL})$, crescidas à $37^{\circ} \mathrm{C}$ sem agitação por 16 horas e estocadas em glicerol $(15 \% \mathrm{v} / \mathrm{v}) \mathrm{em}$ freezer $-80^{\circ} \mathrm{C}$. 


\section{III.4.3. Preparo dos templates para seqüenciamento}

A obtenção de DNA de plasmídeos provenientes das bibliotecas "shotgun" de DNA genômico de Xylella fastidiosa, biblioteca de RDA, ou provenientes da subclonagem dos cosmídeos, foi obtido e patronizado basicamente por três diferentes metodologias:

- Lise alcalina por meio de kit QIAGEN ou metodologia modificada pelo Prof.Dr. Marcelo Bento Soares (University of Iowa, EUA) (Apêndice L.1).

- PCR de colônia;

- "Boiling prep" com a utilização de forno de microondas. Desenvolvida pelo Prof.Marcelo Bento Soares (University of Iowa, EUA) (Apêndice L.4).

A metodologia de Mini preparações plasmidiais (Kit QIAGEN ou protocolo adaptado) baseia-se em uma lise alcalina, onde o DNA plasmidial supercoil possui uma maior resistência ao tratamento com agentes desnaturantes em comparação ao DNA cromossômico. Após a desnaturação do DNA cromossômico e tratamento com RNAse A, o meio é neutralizado rapidamente, ocorrendo a precipitação das proteínas, restos celulares e do DNA desnaturado. Recupera-se, do sobrenadante, o DNA plasmidial após uma centrifugação, e este é precipitado e lavado, fornecendo o template necessário para a reação de amplificação e incorporação dos ddNTPs marcados para o posterior seqüenciamento.

A metodologia de PCR de colônia baseia-se na utilização de primers específicos flanqueando o polylinker do vetor utilizado (no caso pUC18 ou pbSK). Convém observar que o método por nós padronizado não se utiliza de colônias provenientes diretamente das placas $\mathrm{LB}$ /ampicilina $(100 \mu \mathrm{g} / \mathrm{mL})$. Os clones recombinantes são primeiramente repicados com auxílio de um palito de dente autoclavado, previamente umedecido com água milliQ também autoclavada (esse processo evita o encharcamento do palito com o meio de cultura da placa estoque) em uma placa "elisa" de fundo redondo denominada de "placa estoque" contendo $100 \mu \mathrm{g} / \mathrm{mL}$ de meio TB (69) e $100 \mu \mathrm{g} / \mathrm{mL}$ de antibiótico ampicilina. São então crescidas overnight sem rotação à $37^{\circ} \mathrm{C}$, estocadas em $15 \%$ glicerol v/v a $-20^{\circ} \mathrm{C}$ até o momento de seu uso.Posteriormente estocadas à $-80^{\circ} \mathrm{C}$. 
Cada reação de PCR é realizada com $0,125 \mathrm{mM}$ de cada dNTP; $0,17 \mu \mathrm{M}$ de cada primer (forward e reverse); $1,5 \mathrm{mM}$ de $\mathrm{MgCl}_{2} ; 1 \mathrm{X}$ tampão da enzima polimerase e $0,6 \mathrm{U}$ de enzima polimerase $(5 \mathrm{U} / \mu \mathrm{L})$.

O template necessário é repicado da placa estoque parcialmente descongelada com o auxílio de um repicador "hedgehog", transferindo o inóculo apenas uma vez. A enzima para qual estas condições foram padronizadas é a BIOLASE DNA Polymerase $(5 \mathrm{U} / \mu \mathrm{L})$. Seu tampão $10 \mathrm{X}$ contém $160 \mathrm{mM}\left(\mathrm{NH}_{4}\right)_{2} \mathrm{SO}_{4} ; 670 \mathrm{mM}$ Tris-Cl $\left(\mathrm{pH} 8,8\right.$ à $25^{\circ} \mathrm{C}$ ) e $0,1 \%$ Tween 20 . Os pares de primers utilizados foram $\mathrm{T}_{3}$ (reverse) e $\mathrm{T}_{7}$ (forward) ou LudF (forward) e LudR (reverse), assim por nós denominados e sintetizados na Universidade de Yale (37).

Os tempos utilizados na reação de amplificação (em Termociclador MJ/PTC100 ou Perkin-Elmer 9700) deste material foram:

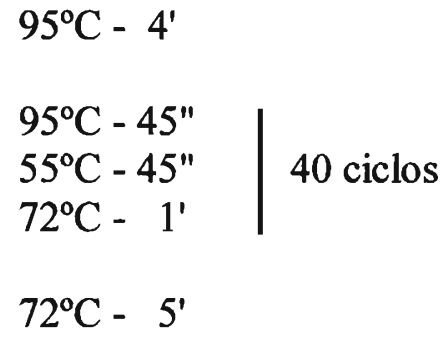

A metodologia de Boiling prep também é baseada em uma lise, sendo que esta é feita através de alta temperatura em microondas de prato giratório. Novamente as proteínas, restos celulares e DNA cromossômico serão precipitados e o sobrenadante conterá o DNA plasmidial utilizado como template para a reação de seqüenciamento.

\section{III.4.4. Seqüenciamento dos insertos}

A partir dos templates obtidos pelas diferentes metodologias acima descritas, ocorre a necessidade da incorporação dos dideóxi-nucleotídeos (ddNTPs) covalentemente ligados a agentes fluorescentes específicos para cada ddNTP, uma vez que a técnica de seqüenciamento utilizado para o projeto é baseado no método de Sanger (73). O método foi modificado pela Applied Biosystems Perkin- Elmer para incluir etapas sucessivas de desnaturação do molde (plasmídeo), pareamento de um único primer (forward por exemplo) e sua extensão pela ação de uma DNA 
polimerase termoestável em termociclador, resultando em uma amplificação linear dos insertos marcados.

Para a reação são utilizados aproximadamente 400ng de DNA plasmidial (ou no caso do PCR de colônia somente o DNA do inserto); 0,8 $\mu \mathrm{M}$ de um único primer $\left(\mathrm{T}_{3}, \mathrm{~T}_{7}, \mathrm{LudF}\right.$ ou LudR); $1 \mathrm{X}(2 \mu \mathrm{L})$ uma solução denominada "save money" (200mM Tris-Cl pH 9,0 e $5 \mathrm{mM} \mathrm{MgCl}_{2}$ ) e $2 \mu \mathrm{L}$ de reagente "BigDye Terminator Cycle Sequencing Ready Reaction Kit with AmpliTaq ${ }^{\circledR}$ (Applied Biosystem, Perkin-Elmer) em um volume final de $10 \mu \mathrm{L}$. Para a utilização de apenas $1 / 4$ do volume recomendado pela empresa do BigDye Terminator foi necessária a complementação do meio de reação com o denominado "save money" propiciando novamente as condições salinas ideais para a ação da enzima.

A reação de amplificação ficou padronizada com os seguintes tempos (em Termociclador MJ/PTC 100 ou Perkin-Elmer 9700):

$$
\begin{array}{l|l}
95^{\circ} \mathrm{C}-30^{\prime \prime} & \\
55^{\circ} \mathrm{C}-30^{\prime \prime} & 35 \text { ciclos } \\
60^{\circ} \mathrm{C}-3^{\prime} &
\end{array}
$$

Após a reação, cada amostra de DNA amplificado é precipidado com 2 volumes de etanol gelado $100 \%$ e $80 \mathrm{mM}$ de Acetato de sódio $\mathrm{pH} 5,2$ e $0,03 \mathrm{~g} / \mathrm{L}$ de glicogênio. Incuba-se as amostras em gelo por 15 minutos; centrifuga-se por 30 minutos a $6000 \mathrm{rpm}$ (ou 20 minutos à $14.000 \mathrm{rpm}$ caso a reação esteja sendo feita em tubos de eppendorf e não em placa) e lava-se o pellet obtido com $25 \mu \mathrm{L}$ de uma solução $75 \%$ etanol gelado. Após uma nova centrifugação por 10 minutos à $6000 \mathrm{rpm}$ (ou 8 minutos à $14000 \mathrm{rpm}$ ) e secagem à temperatura ambiente, na bancada, do pellet obtido, este foi ressuspenso em $2 \mu \mathrm{L}$ de tampão apropriado (1 parte Blue Dextran em solução de EDTA $25 \mathrm{mmol} / \mathrm{L}$ para 5 partes de formamida deionizada), denaturado por 1 minuto à $92^{\circ} \mathrm{C}$ e aplicados $(1,5 \mu \mathrm{L})$ em gel de seqüenciamento $(36 \mathrm{~cm}$ de comprimento). O gel foi corrido em seqüenciador automático ABI 377 DNA Sequencer (Applied Biosystems, Perkin-Elmer).

Os géis de seqüenciamento foram preparados utilizando-se uma mistura concentrada de acrilamida/ bisacrilamida Long Ranger ${ }^{\mathrm{TM}} 50 \%$ (FMC). A 
concentração final de tal solução de acrilamida foi a de 5,4\% (\%v/v) adicionando-se tampão TBE (69) $1 \%(\% \mathrm{v} / \mathrm{v})$ e uréia $0,36 \mathrm{~g} / \mathrm{mL}(5 \mathrm{~mol} / \mathrm{L})$.

A aquisição dos dados pelo seqüenciador automático $\mathrm{ABI} 377$ foi feita pelos módulos de programação do seqüenciador para eletroforeses desenvolvidas em gel de $36 \mathrm{~cm}$, química de seqüenciamento $\mathrm{BigDye}^{\mathrm{TM}}$, tanto a $1200 \mathrm{~V}$ para 7 horas de aquisição de dados (Seq Run 36E-1200) quanto a $2400 \mathrm{~V}$ para 3,5 horas de aquisição de dados (Seq Run 36E-2400).

Os dados foram coletados por programa ABI Prism Collection (Applied Biosystems, Perkin-Elmer) em um microcomputador Power Macintoch 7300/200 (Apple Microcomputer Inc). As análises dos géis provenientes dos seqüenciamentos foram realizadas pelo programa Sequencing Analysis v3.3 (Applied Biosystems, Perkin-Elmer) no mesmo computador ou então em um Power Macintoch G3 (Apple Microcomputer Inc), fornecendo um cromatograma para cada amostra, que foi então enviado ao laboratório de bioinformática.

\section{III.4.5. Preparo dos templates e seqüenciamento diretamente do genoma de Xylella fastidiosa.}

Um pellet bacteriano doado pelo Prof.Dr. Marcos Machado, resultado do crecimento de $250 \mathrm{~mL}$ de cultura por 2 semanas nos foi entregue. Utilizamos aproximadamente $30 \%$ deste material para a obtenção do DNA genômico da bactéria por meio de uma midi preparação com kit QIAGEN. Ao final desta extração obtivemos $150 \mu \mathrm{L}$ de DNA bacteriano ressuspensos em TE pH 8,0. Esse volume foi incubado por 2 horas à $55^{\circ} \mathrm{C}$; tratamento necessário para deixar a solução mais homogênea e conseguir uma quantificação mais precisa de sua concentração. Com os resultados obtidos em leitura em espectofotômetro, obtivemos uma concentração estimada de $1 \mu \mathrm{g} \mathrm{DNA} / \mu \mathrm{L}$, ou seja, possuíamos um equivalente de $150 \mu \mathrm{g}$ de DNA genômico.

Adaptando-se o protocolo descrito por Heiner et al (31), foi utilizado 2,5 $\mu \mathrm{g}$ deste DNA genômico em uma reação com 25 pmol de primer e $16 \mu \mathrm{L}$ do reagente :BigDye Terminator Cycle Sequencing Ready Reaction Kit" (Applied Biosystems, Perkin-Elmer) em $40 \mu \mathrm{L}$ finais, completados com água milliQ. 
Os primers foram sintetizados com base na análiseda sequência das pontas de alguns dos mais longos contigs existentes naquele momento (no banco de sequências do projeto, no centro computacional LBI de Campinas), constituindo em seqüencias de em média 25 nucleotídeos.

O DNA genômico foi descongelado e previamente aquecido para aumentar sua solubilização e garantir que a concentração deste DNA estivesse correlacionado com a concentração medida antes do congelamento e, além disso, este DNA juntamente com a água milliQ estéril sofreu um processo de "shearing", forçando-se a passagem da solução por 7 vezes através de uma seringa com agulha fina G21x1. Este tratamento é necessário para quebrar o DNA, facilitando sua desnaturação e permitindo que o template esteja em uma conformação que favoreça o annealing dos primers). Somente após tal tratamento no DNA é que os outros reagentes são adicionados para a reação de seqüenciamento seguindo protocolo abaixo (realizado em Termociclador Pekin-Elmer 9700):

$$
\begin{array}{l|l}
95^{\circ} \mathrm{C}-5^{\prime} & \\
95^{\circ} \mathrm{C}-30^{\prime \prime} & \\
55^{\circ} \mathrm{C}-20^{\prime \prime} & 60 \text { ciclos } \\
60^{\circ} \mathrm{C}-4^{\prime} &
\end{array}
$$

A precipitação, lavagem,aplicação em gel de seqüenciamento e obtenção dos cromatogramas foram feitas como descritas anteriormente.

\section{III.4.6. Seqüenciamento total de clones provenientes das bibliotecas de "shotgun" genômico.}

No decorrer do projeto, com o seqüenciamento dos cosmídeos e a retomada da construção e seqüenciamento das bibliotecas "shotgun" notou-se que ainda existiam regiões do genoma não cobertas, denominados "gaps". Observou-se que alguns clones "shotgun" possuíam suas extremidades correspondentes às seqüências de extremidades dos contigs montados pelos cosmídeos, decidindo-se então pelo completo seqüenciamento desses clones para validar tais regiões e por vezes extender 
os ditos "gaps". Tais seqüências foram determinadas como GFSs ("Gap-filling Sequences") (Apêndice E).

Tais clones "shotgun" foram tratados de maneira análoga aos cosmídeos, construindo-se sub-bibliotecas de seus insertos. A metodologia utilizada foi novamente a de nebulização do DNA (maxi preparação por kit QIAGEN) em glicerol, como já descrito anteriormente. Devido ao menor tamanho de inserto foi necessário maior número de pulsos de nebulização. Enquanto que para a construção das subbibliotecas provenientes dos cosmídeos foram utilizados 3 pulsos de 40 segundos/cada, para a eficiente fragmentação do DNA do plasmídeo por nebulização, o DNA proveniente de clones "shotgun" foi tratado com 10 pulsons de 40 segundos/cada, com menor recuperação de material.

O tratamento do DNA nebulizado com as enzimas necessárias para reparo das extremidades, a ligação e transformação foram feitos como escrito anteriormente, para a construção das sub-bibliotecas a partir dos cosmídeos. Uma observação porém foi a escolha, por eletroforese em gel de agarose preparativo, dos tamanhos dos fragmentos gerados por tal processo: 0,7 a $1,3 \mathrm{kB}$. 


\section{III.5. Montagem dos cosmídeos a partir dos cromatogramas}

obtidos.

Após o seqüenciamento e obtenção dos cromatogramas dos clones das subbibliotecas randômicas dos cosmídeos, começava-se a realizar a remontagem destes cosmídeos com auxílio de programas de computador. Os programas de bioinformática utilizados para tal fim foram phred/phrap/crossmatch (16, 17) e consed (27), instalados em uma estação Digital (Compaq) sob sistema UNIX em nosso laboratório.

A remontagem da sequêencia de um dado cosmídeo é dada pela ordenação das sequências obtidas para os clones de sub-bibliotecas randômicas. Tal ordenação é baseada na similaridade entre as seqüências e alguns critérios de qualidade estabelecidos para o projeto, resultando na formação de alguns contigs até a obtenção de um único contig, representando a seqüência do cosmídeo.

A qualidade do seqüenciamento foi dada para cada base individual pela análise de seu cromatograma pelo programa phred, sendo arquivada em formato FASTA, habilitando a sua utilização na melhoria do "assembly" pelo programa phrap. Phred utiliza o método simples de Fourier para determinar onde os picos de leitura (das bases) deveriam estar centralizados se não houvessem compressões, manchas ou outros fatores os "modificando" de seus "verdadeiros" locais. Com base nas características dos traços de picos encontrados, phred computa a probabilidade $\mathrm{p}$ de erro no "base call" em cada posição convertendo esta probabilidade em um valor de qualidade $q$ usando a fórmula: $q=-10 \log (p)$. Por exemplo: uma probabilidade de erro $\mathrm{p}=1 / 1000$ corresponde à um valor de phred $\mathrm{q}=30$. No projeto, a qualidade mínima estabelecida foi a de $q=20$, ou seja, uma probabilidade de erro de 1 em 100 pares de bases.

Após a determinação da qualidade destas bases, ocorre a comparação das seqüências e a montagem dos contigs através dos programas crossmatch e phrap. A visualização gráfica proveniente de tais montagens e determinação de regiões com qualidade baixa, seqüenciamento em uma única fita ou discrepâncias de alta qualidade é feita através do programa consed. Tais programas são rapidamente mencionados abaixo.

Phrap ("phragment assembly program" ou "phil's revised assembly program") -um programa para "montagem" de dados de seqüências de DNA- possibilita o uso de 
seqüências inteiras (e não somente as partes de alta qualidade) e utiliza as informações de qualidade dadas pelo phred para melhorar a "montagem" na presença de regiões repetitivas.

O programa denominado de cross_match possui o propósito de comparar dois sets de seqüências de DNA. No projeto ele foi utilizado para comparar um grupo de seqüências com um grupo de seqüências de vetores, produzindo versões de seqüências com vetores mascarados, não necessários à montagem do genoma de Xylella fastidiosa.

Nos seqüenciamentos de grandes clones ou pequenos genomas feitos pela técnica de "shotgun" existem duas fases: a primeira corresponde à obtenção dos reads e posterior formação de contigs, a segunda é a fase de término, na qual o assembly deve ser corrigido dos vários tipos de anomalias que pode apresentar (reads contaminantes, seqüências de vetores não removidas, reads quiméricos entre outros). Além disso, os "gaps" devem ser fechados, as regiões de baixa qualidade resolvidas e, quando necessário, a edição deve ser feita manualmente para corrigir o "assembly" ou erros de "base-calling". O finishing representa então um grande esforço em um projeto de seqüenciamento;a redução da necessidade da interferência humana e manutenção de alta eficiência são essenciais para um programa para tal fim designado. O programa consed utilizado tenta implementar tais princípios.

Quando obtido somente um contig de tamanho condizente com o inserto do cosmídeo, o arquivo era enviado ao centro de bioinformática do projeto, localizado na cidade de Campinas no Campus da Universidade Estadual de Campinas (UNICAMP) para a sua validação quanto aos critérios de montagem.

Tais critérios são mencionados abaixo:

- Todos os cromatogramas utilizados para a montagem do cosmídeo deveriam estar presentes no banco computacional do centro de bioinformática.

- O contig resultante da montagem deveria apresentar seqüências de vetor Lawrist4 somente em suas extremidades, flanqueando o inserto.

- A taxa de erro esperada para a montagem deveria ser menor ou igual a 1 base em 10.000 .

- Cada base do consenso obtido na montagem deveria ser confirmada por pelo menos uma seqüência em cada fita e possuir qualidade dada pelo phred igual ou maior do que 20 . 
- Em cada seqüência não deveria haver bases com qualidade phred igual ou maior a 40 (probabilidade de erro 1/10.000) discordando da seqüência consenso.

Preenchido todos esses critérios o arquivo enviado era então considerado terminado ("finished"). $\mathrm{O}$ arquivo quando possuia seqüência consenso com regiões de baixa qualidade, ou então regiões representadas somente em uma fita, era classificado como quase terminado ("close to finished") ou, se houvessem ainda muitas regiões desta forma como "one contig".

Após o fechamento do cosmídeo tornou-se possível uma verificação, por "digestão computacional", da sequiência inserida no vetor Lawrist4 e a comparação com resultados provenientes da digestão com enzima de restrição, obtidos antes do seqüenciamento. 


\section{III.6. Predição de ORFs nos cosmídeos}

Com o seqüenciamento em progresso e a geração de grande quantidade de dados, uma análise e anotação de prováveis genes existentes no genoma de Xylella fastidiosa foi iniciada.

As ORFs disponibilizadas para que fossem realizadas as suas anotações foram primeiramente preditas automaticamente pelo programa GLIMMER no centro computacional do projeto. Tal programa se encontra disponível em site internet (44) e se baseia na utilização do modelo interpolado de Markov para encontrar regiões codificadoras em genomas microbianos.

O programa faz uma busca em seqüências de DNA por regiões com alta probabilidade estatística de codificarem proteína determinando fases abertas de leitura (ORFs = "open reading frames") que se iniciassem nos códons ATG, GTG e TTG e terminassem por códons TAG, TAA e TGA. O programa foi treinado previamente com seqüências de DNA da própria Xylella para verificação estatística da utilização destes códons de início e término.

As ORFs preditas foram colocadas em programa Sequin (03) onde eram então colocadas em ordem em suas posições em relação ao cosmídeo e traduzidas em fase de leitura correta. Os arquivos sequin assim organizados eram então disponibilizados pelo laboratório de bioinformática aos demais grupos. 


\section{III.7. Anotação das ORFs}

A anotação de uma ORF constitui na atribuição de uma função putativa para esta ORF de acordo com a similaridade que sua seqüência protéica, obtida na tradução da ORF, apresente com uma seqüência de uma proteína já conhecida (ou seja, confirmada por experimentos bioquímicos)

Esta busca de similaridade entre seqüências protéicas foi realizada através de programa BLASTp (01), utilizando a matriz de comparação BLOSUM 62 no banco de dados público não redundante, Gene Bank, disponibilizado pelo NCBI (National Center for Biotechnology Information) (43).

A anotação ficou a critério de cada anotador, ou seja, houve uma decisão individual para a denominação das preditas ORFs. A nomenclatura porém foi seguida segundo alguns critérios de anotação determinados pela coordenação do projeto, sendo elas descritas abaixo:

- Putative X protein ou putative Xase: para aquelas ORFs cuja probabilidade de similaridade por caso fortuito (e-value) com uma proteína de função conhecida presente no banco de dados fosse menor que $10^{-5}$.

- Conserved Hypothetical X kDa protein: para aquelas ORFs cujo e-value fosse menor que $10^{-5}$ com uma proteína de função desconhecida presente no banco de dados.

- Hypothetical X kDa protein: para aquelas ORFs cujas seqüências não eram similares a nenhuma das proteinas presentes no banco de dados, ou para aquelas onde o e-value fosse maior ou igual a $10^{-3}$.

Quando ocorria a probabilidade de similaridade por caso fortuito (e-value) entre $10^{-5}$ e $10^{-3}$, utilizava-se o programa denominado PSI-BLAST (position-specific iterated BLAST) (02) e uma busca dentro do banco de dados de famílias de proteínas e de domínios em proteínas (Pfam). A observação de possíveis operons também favoreceu a anotação dos cosmídeos recebidos. Maiores detalhes, exemplos e comentários podem ser vistos na parte de resultados.

Além de determinar as similaridades e com elas inferir uma possível função para as ORFs, foram incluídas nas anotações informações, quando existentes, a respeito de detalhes da função da proteína, da reação que participa, o código da proteína mais similar encontrada no banco de dados, a probabilidade da semelhança 
entre as duas proteínas ser um caso fortuito (e-value), ou seja, a maior quantidade possível de informações relevantes sobre a proteína semelhante.

Cada ORF anotada também foi classificada de acordo com uma tabela préexistente determinada por Monica Riley (Apêndice $\mathbf{J}$ ) para os genes de Escherichia coli baseando-se na participação das proteínas nas diferentes rotas metabólicas existentes no organismo. Com o progresso das anotações, foi construída uma tabela de classificação especialmente feita pelo consenso dos grupos participantes do projeto para a bactéria Xylella fastidiosa (Apêndice K), baseada na tabela de E.coli. 


\section{Resultados}

$\mathrm{O}$ nosso laboratório, denominado $\mathrm{QV}$, colaborou no projeto com o seqüenciamento de 7 cosmídeos e diversos clones provenientes de diferentes bibliotecas de"shotgun" genômico. Colaborou também com o seqüenciamento total de 7 clones "shogun", seqüenciamento diretamente do genoma do fitopatógeno, e ficou responsável pelo seqüenciamento de parte da biblioteca RDA juntamente com o grupo IL (Instituto Ludwig- São Paulo, SP) visando o fechamento dos "gaps" existentes. Algumas seqüências de extremidades de cosmídeos foram feitas mas não são descritas.

Realizamos a anotação prévia de aproximadamente 290 ORFs (Open reading frames ou fases abertas de leitura) provenientes de $210 \mathrm{~Kb}$ do genoma de Xylella fastidiosa, em cosmídeos seqüenciados por nosso grupo e também por outros integrantes do projeto.

\section{IV.1. Cosmídeos}

Tabela 02: Distribuição percentual dos reads necessários para o término de cada cosmídeo seqüenciado em nosso laboratório. As colunas com nome de Reads ** determinam as percentagens de reads utilizados para o término do respectivo cosmídeo obtidas pelos processo de nebulização (sub-bibliotecas randômicas), shotgun (construídas para o projeto), construção de primers internos específicos e de sub-bibliotecas construídas para os cosmídeos sobrepostos.

\begin{tabular}{|c|c|c|c|c|c|c|c|}
\hline Nome & $\begin{array}{c}\text { Tamanho } \\
\mathbf{( p b )}\end{array}$ & $\begin{array}{c}\text { Reads } \\
\text { Nebuliz } \\
(\%)\end{array}$ & $\begin{array}{c}\text { Reads } \\
\text { Shotgun } \\
(\%)\end{array}$ & $\begin{array}{c}\mathbf{N}^{\circ} \\
\text { primers }\end{array}$ & $\begin{array}{c}\text { Reads } \\
\text { Primers } \\
(\%)\end{array}$ & $\begin{array}{c}\text { Reads } \\
\text { Sobrepos. } \\
(\%)\end{array}$ & $\begin{array}{c}\text { Total } \\
\text { (reads) }\end{array}$ \\
\hline $\mathbf{0 7 B 0 3}$ & 39.278 & $46,4 \%$ & $\mathbf{8 , 0} \%$ & 31 & $3,5 \%$ & $30,4 \%$ & 1025 \\
\hline $\mathbf{1 1 B 0 8}$ & 39.469 & $46,5 \%$ & $\mathbf{8 , 7} \%$ & 15 & $1,0 \%$ & $22,3 \%$ & 1163 \\
\hline $\mathbf{0 8 A 0 3}$ & 38.066 & $40,0 \%$ & $5,2 \%$ & 10 & $0,4 \%$ & $48,9 \%$ & 1114 \\
\hline $\mathbf{0 3 D 0 3}$ & 39.433 & $43,2 \%$ & $7,2 \%$ & 4 & $0,2 \%$ & $44,9 \%$ & 1101 \\
\hline $\mathbf{0 4 A 0 9}$ & 38.656 & $\mathbf{6 1 , 4} \%$ & $\mathbf{7 , 5} \%$ & 4 & $0,1 \%$ & $30,7 \%$ & 1272 \\
\hline $\mathbf{1 0 F 1 1}$ & 34.418 & $28,9 \%$ & $12,2 \%$ & - & - & $58,8 \%$ & 1183 \\
\hline $\mathbf{2 0 F 1 1}$ & 4.437 & $26,8 \%$ & $3,7 \%$ & - & - & $68,8 \%$ & 138 \\
\hline $\mathbf{0 6 H 0 3}$ & 37.463 & $54,6 \%$ & $12,0 \%$ & - & - & $33,0 \%$ & 1417 \\
\hline
\end{tabular}


A tabela acima mostra uma comparação total dos "8" cosmídeos seqüenciados (os cosmídeos denominados de 10F11 e 20F11 representam a separação de inserto quimérico). Podemos perceber que todos os insertos possuem aproximadamente o mesmo tamanho (média de 38.700 por inserto).

A primeira observação que podemos fazer é a de que o número necessário de reads para o término de cada um dos cosmídeos (novamente considerando os insertos X0QV-10F11 e X0QV-20F11 como um único dado) foi constante em todo o decorrer do projeto em nosso laboratório (média de 1021 clones por inserto) a despeito da experiência adquirida com os cosmídeos iniciais. Observando porém a distribuição destes reads, notamos que nos primeiros cosmídeos recebidos, principalmente para o cosmídeo X0QV-07B03, o número de primers que tiveram que ser construídos foi de número superior (Tabela 02), chegando a representar uma percentagem de 3,5\% dos reads necessários para o término do cosmídeo (vide Tabela 02).

A utilização de primers era feita de acordo com decisões tomadas em virtude do andamento do seqüenciamento para cada inserto. Em alguns casos os primers eram necessários já que o exaustivo seqüenciamento das sub-bibliotecas de shotgun mostrava que havia uma distribuição não homogênea dos reads ao longo de certo cosmídeo. Estatisticamente tornava-se então mais econômico a utilização de primers para fechar gaps não representados nas sub-bibliotecas. A utilização dos primers também era feita quando pequenas regiões de baixa qualidade, dada pelo programa phred, ainda existiam; ou ainda quando haviam regiões representadas somente por uma fita, fazendo com que, apesar da probabilidade de erro de 1/10.000 dada pelo programa correspondesse ao mínimo exigido pela coordenação do projeto, as outras exigências (confirmação da sequiência nas duas fitas, discrepância de todas as bases de acordo com o consenso menor do que $q=40$ etc) não fossem atendidas.

Especificamente, para o cosmídeo X0QV-07B03 foram utilizados 31 primers internos para o seu término, muito diferente do que podemos observar para os últimos cosmídeos ou até mesmo para os cosmídeos que a ele sucederam (X0QV-11B08 ou X0QV-08A03 com 15 e 10 primers sintetizados). Este padrão de diminuição de necessidade de utilização de primers internos específicos para cada cosmídeos pode ser observado nas percentagens relativas apresentadas na tabela 02 acima. Tal fato se deve pela experiência obtida a cada novo cosmídeo seqüenciado, fazendo com que as sub-bibliotecas construídas por metodologia de nebulização representasse mais aleatoriamente o cosmídeo referente. 
Outra conclusão que podemos extrair da tabela é o fato de que para os cosmídeos X0QV-10F11 e X0QV-20F11 a percentagem de reads provenientes de cosmídeos sobrepostos $(58,8 \%$ e $68,8 \%$, respectivamente) foi superior à média encontrada para os demais cosmídeos sequienciados. Como veremos descrito nas próximas páginas, foi descoberto que o inserto denominado primeiramente de $\mathrm{X} 0 \mathrm{QV}$ 10F11 era quimérico, sendo então dividido em dois: a região de maior tamanho permaneceu como X0QV-10F11 e o de menor tamanho foi então denominado de XOQV-20F11. Estes dois "novos" cosmídeos se mostraram similares a duas regióes já bem caracterizadas no genoma e por tal fato apresentaram uma alta percentagem de reads provenientes de cosmídeos sobrepostos.

Outras considerações que podemos fazer em relação à Tabela acima é a de que, em geral, a percentagem de utilização de clones provenientes das sub-bibliotecas construídas foi semelhante em todos os cosmídeos assim como a utilização de reads provenientes das bibliotecas de "shotgun" construídas para o projeto e por todos os grupos seqüenciadas.

Abaixo seguem-se relatos e observações específicas em respeito a cada cosmídeo seqüenciado pelo grupo $\mathrm{QV}$.

\section{IV.1.1 Cosmídeo X0QV-07B03}

O cosmídeo X0QV-07B03 foi o primeiro recebido em nosso laboratório. Para tal cosmídeo foram tentadas duas diferentes estratégias para a formação das subbibliotecas de plasmídeos: obtenção de fragmentos por método enzimático ou por método físico.

Pela metodologia enzimática foram construídas duas bibliotecas: Alu I e Sau3A I. A primeira representava a biblioteca cujos fragmentos foram obtidos pela digestão parcial do cosmídeo com a enzima Alu I clonados em sítio EcoR V do vetor pbSK e a segunda representava a biblioteca cujos fragmentos foram obtidos pela digestão parcial do cosmídeo com a enzima Sau3A I clonados em sítio BamH I do mesmo vetor. Tais bibliotecas, principalmente a denominada Sau3A I, se mostraram ineficientes por apresentar co-ligações de fragmentos e uma representatividade muito redundante, ou seja, algumas regiões do cosmídeo estavam amplamente representadas enquanto outras regiões permaneciam pouco seqüenciadas como podemos observar na 
Figura 07. Tal metodologia de fragmentação enzimática foi utilizada novamente no cosmídeo X0QV-11B08 (digestão com Alu I) mas abandonada nos demais cosmídeos recebidos devido às razões acima expostas.
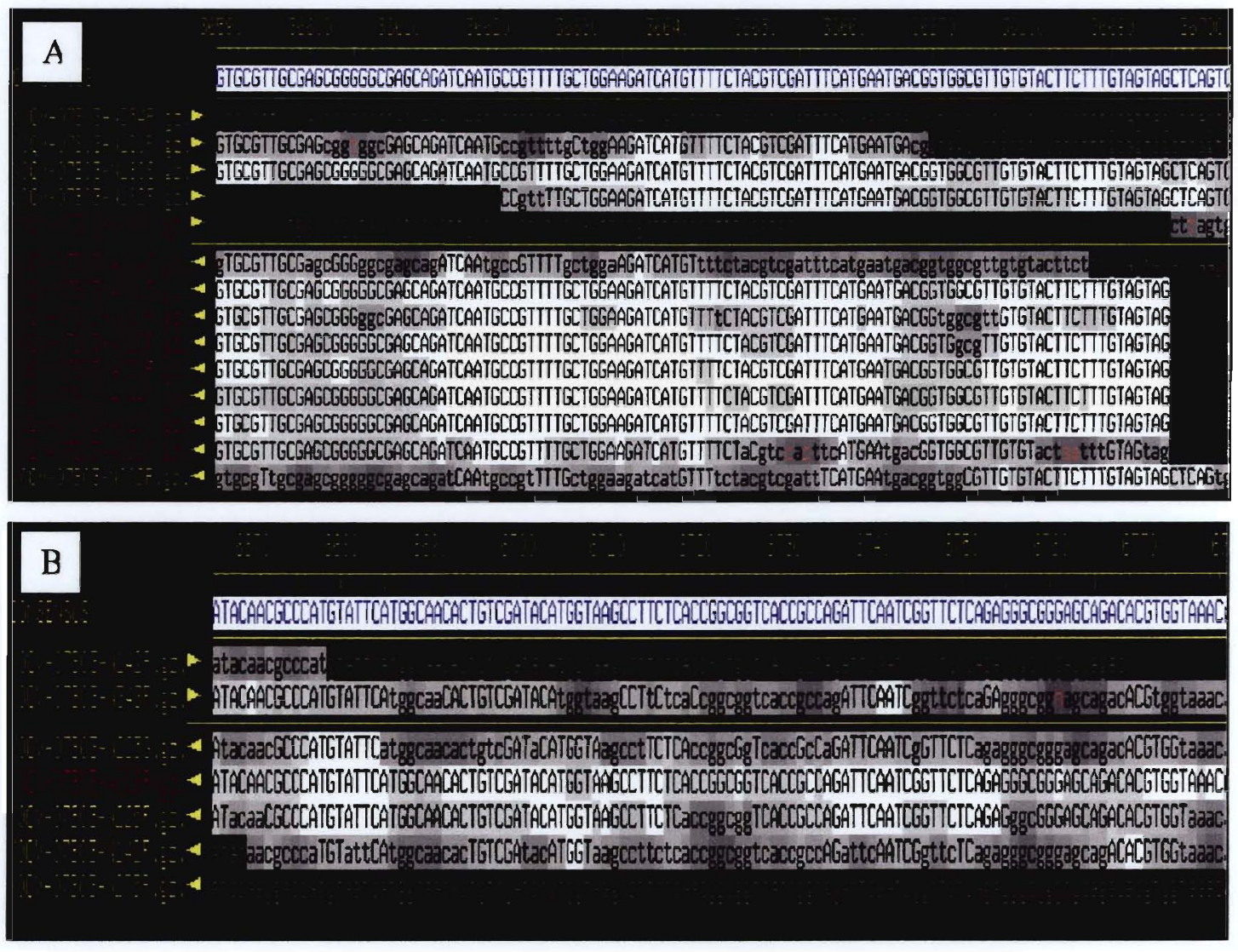

Figura 07: Regiões do cosmídeo X0QV-07B03 com grande representação (A) de insertos provenientes de biblioteca gerada por fragmentação enzimática (em lilás) ou com pequena representação (B).

Tentou-se também a obtenção dos fragmentos a serem clonados em plasmídeos duas metodologias físicas: a sonicação e a nebulização. Não obtivemos sucesso na tentativa da construção de uma biblioteca por sonicação, sendo padronizado no laboratório a segunda metodologia, resultando em bibliotecas randômicas de fragmentos escolhidos entre 1,3 e $2,3 \mathrm{~Kb}$ em gel preparativo de agarose, clonados em vetor $\mathrm{pbSK}$, em sítio EcoR V defosforilado.

Para a montagem e finalização deste cosmídeo de 39.278 pb foram utilizadas 1025 seqüências, distribuídas em 607 seqüências provenientes das bibliotecas construídas com o DNA deste cosmídeo pelas diferentes metodologias, do 
seqüenciamento com utilização de primers construídos para o fechamento ou melhoria de qualidade do inserto ou pelo seqüenciamento de suas extremidades com a utilização dos primers do vetor Lawrist4; 322 seqüências provenientes de cosmídeos que se sobrepõem ao cosmídeo X0QV-07B03 (X0QV-03D03, X0RP-07B10 e X0**_ 06C06); 82 seqüências provenientes das bibliotecas de "shotgun" genômico e 14 outras sequiências de bibliotecas provenientes de outros cosmídeos que possuíam certa similaridade com regiões do X0QV-07B03 mas não localizados fisicamente próximos a este. A distribuição das seqüências utilizadas na "montagem" do cosmídeo X0QV07B03 está esquematizada na tabela 03 .

Como já mencionado na página 43, foram sintetizados 31 primers internos para o término deste cosmídeo, fazendo com que a percentagem de reads provenientes do seqüenciamento de insertos utilizando-se estes primers alcançassem o número de 3,5\%. Estes primers foram denominados de $\mathrm{P}$ quando foram sintetizados visando o fechamento de gaps existentes ou X quando a intenção ao utilizá-los foi a de melhoria de qualidade em algumas regiões do inserto.

Tabela 03: Distribuição de seqüências utilizadas na montagem e finalização do cosmídeo X0QV-07B03.

\begin{tabular}{|c|l|c|c|}
\hline \multirow{2}{*}{ Cosmídeo } & \multicolumn{2}{|c|}{ Biblioteca } & $\%$ \\
\hline \multirow{4}{*}{ X0QV-07B03 } & Alu I (A) & 93 & $9,1 \%$ \\
\cline { 2 - 4 } & Nebulização (N) & 476 & $46,4 \%$ \\
\cline { 2 - 4 } & Pontas (L ou R) & 2 & $0,2 \%$ \\
\cline { 2 - 4 } & Primers (P ou X) & 36 & $3,5 \%$ \\
\cline { 2 - 4 } & TOTAL & $\mathbf{6 0 7}$ & $\mathbf{5 9 , 2} \%$ \\
\hline \multirow{4}{*}{ X0QV-03D03 } & Nebulização (N) & 116 & $11,3 \%$ \\
\cline { 2 - 4 } & Ponta (R) & 1 & $0,1 \%$ \\
\cline { 2 - 4 } & Primer (Z) & 1 & $0,1 \%$ \\
\cline { 2 - 4 } & TOTAL & $\mathbf{1 1 8}$ & $\mathbf{1 1 , 5} \%$ \\
\hline X0RP- 07B10 & (A) & $\mathbf{1 9 3}$ & $\mathbf{1 8 , 8} \%$ \\
\hline X0RP-06C06 & (K) & $\mathbf{6}$ & $\mathbf{0 , 6} \%$ \\
\hline X0RU-06C06 & (K ou L) & $\mathbf{1}$ & $\mathbf{0 , 5} \%$ \\
\hline X0QV-06C06 & Ponta (L) & $\mathbf{8 2}$ & $\mathbf{1 0} \%$ \\
\hline Shotgun & & $\mathbf{1 4}$ & $\mathbf{1 , 4} \%$ \\
\hline outros & & $\mathbf{1 0 2 5}$ & $\mathbf{1 0 0 \%}$ \\
\hline TOTAL & & & \\
\hline
\end{tabular}

Após a montagem e finalização do cosmídeo a taxa de erro final do inserto X0QV-07B03 foi de $0.08 / 10.000$ bp. Para a finalização da qualidade do cosmídeo 
haviam diversas bases discrepantes do consenso, porém apresentando qualidade phred igual ou superior 40 (discrepância de alta qualidade do consenso). A análise detalhada dos géis mostrava grandes manchas de dye-terminator livre não incorporado no início dos reads, o que causava óbvios erros de leitura. Além disso, neste primeiro cosmídeo, deixamos o base-caller do ABI determimar o início do read por conta própria, pegando os scans muito no início, de péssima qualidade. Tais bases discrepantes, obviamente resultantes de manchas de dye-terminator foram então corrigidas manualmente, como também foi corrigido manualmente o assembly.

\section{IV.1.2. Cosmídeo X0QV-11B08}

O segundo cosmídeo recebido foi o denominado X0QV-11B08. Para a construção de sub-bibliotecas usamos a digestão do cosmídeo com a enzima Alu I (fragmentos clonados em sítio EcoR V do vetor pbSK) e a metodologia de quebra por nebulização, com fragmentos escolhidos entre 1,3 e 2,3 $\mathrm{Kb}$ e clonados em sítio EcoR Vdo vetor pbSK. A metodologia de quebra enzimática por Sau3A I e quebra mecânica por sonicação não foram utilizadas.

Para a montagem e finalização deste cosmídeo de 39.469 pb foram utilizadas 1163 seqüências, distribuídas em 745 seqüências provenientes das sub-bibliotecas construídas para o cosmídeo X0QV-11B08, do seqüenciamento de suas extremidades pela utilização dos primers do vetor Lawrist4 ou do seqüenciamento com utilização de primers desenhados para o fechamento ou melhoria de qualidade do inserto; 259 seqüências provenientes de cosmídeos que se sobrepõem ao cosmídeo X0QV-11B08 (X0IC-07F02 e X0II-09C12); 101 provenientes de bibliotecas de "shotgun" genômico e 74 seqüências de bibliotecas provenientes de outros cosmídeos. A distribuição das sequiências utilizadas na montagem e finalização do cosmídeo X0QV-11B08 está esquematizada na tabela abaixo (Tabela 04).

Foram sintetizados 15 primers internos (Y) com a finalidade de melhoria de qualidade de pequenas regiões existentes no inserto. Apesar de exaustivamente seqüenciadas, as sub-bibliotecas não possuiam representação de tais regiões. 
Tabela 04: Distribuição de seqüências utilizadas na montagem e finalização do cosmídeo X0QV-11B08.

\begin{tabular}{|c|l|c|c|}
\hline \multirow{2}{*}{ Cosmídeo } & \multicolumn{2}{|c|}{ Biblioteca } & $\%$ \\
\hline \multirow{3}{*}{ X0QV-11B08 } & Alu I (A) & 188 & $16,2 \%$ \\
\cline { 2 - 4 } & Nebulização (N) & 541 & $46,5 \%$ \\
\cline { 2 - 4 } & Pontas (L ou R) & 4 & $0,3 \%$ \\
\cline { 2 - 4 } & Primers (X ou Y) & 12 & $1,0 \%$ \\
\cline { 2 - 4 } & TOTAL & $\mathbf{7 4 5}$ & $\mathbf{6 4 , 0} \%$ \\
\hline X0IC-07F02 & (Y) & $\mathbf{1 8 5}$ & $\mathbf{1 5 , 9} \%$ \\
\hline X0II-09C12 & (A ou L) & $\mathbf{7 4}$ & $\mathbf{6 , 4} \%$ \\
\hline Shotgun & & $\mathbf{1 0 1}$ & $\mathbf{8 , 7} \%$ \\
\hline Outros & & $\mathbf{1 1 6 3}$ & $\mathbf{5 , 0} \%$ \\
\hline TOTAL & & $\mathbf{1 0 0 \%}$ \\
\hline
\end{tabular}

Após a montagem e finalização do cosmídeo a taxa de erro final do inserto X0QV-11B08 foi de $0.00 / 10.000$ bp. Com a finalização pode-se então fazer uma comparação do mapa de restrição com as enzimas BamH I, EcoR I e Hind III, feitos anteriormente ao seqüenciamento, com o resultado dado pela digestão eletrônica do inserto. As bandas obtidas destas duas formas foram correspondentes, confirmando o seqüenciamento e montagem do cosmídeo.

\section{IV.1.3. Cosmídeo X0QV-08A03}

O cosmídeo X0QV-08A03 foi o terceiro recebido pelo laboratório. Foi utilizada somente a metodologia de fragmentação mecânica por nebulização para a construção das sub-bibliotecas de plasmídeos, escolhendo-se fragmentos entre 1,3 e $2,3 \mathrm{~Kb}$, clonados em sítio EcoR V do vetor pbSK.

Para a montagem e finalização deste cosmídeo de 38.066 pb foram utilizadas 1114 seqüências, distribuídas em 452 seqüências provenientes das bibliotecas construídas para o cosmídeo X0QV-08A03, do seqüenciamento de suas extremidades pela utilização dos primers do vetor Lawrist4, ou do seqüenciamento com utilização de primers construídos para o fechamento ou melhoria de qualidade do inserto; 545 seqüências provenientes de cosmídeos que se sobrepõem ao X0QV-08A03 (X0UT- 
07A07, X0JJ-09E09 e X0QR-07H04); 58 das bibliotecas de "shotgun" genômico e 59 outras seqüências provenientes de outros cosmídeos. A distribuição das seqüências utilizadas na montagem e finalização do cosmídeo X0QV-08A03 está esquematizada na tabela abaixo (Tabela 05):

Após o seqüenciamento de dois cosmídeos que serviram mais como aprendizado, este terceiro cosmídeo começou a representar o padrão seguido para os cosmídeos seguintes: metodologia única (nebulização) utilizada para a obtenção das sub-bibliotecas de "shotgun" necessárias; análise individual de reads provenientes do seqüenciador automático eliminando a região inicial de baixa qualidade e manchas. Tais cuidados permitiram a menor necessidade de síntese de primers internos. Para este cosmídeo foram sintetizados somente 10 primers, com a utilização de 4 reads provenientes do seqüenciamento utilizando-se de tais primers. Tal dado é apresentado na tabela abaixo pela percentagem de apenas $0,4 \%$ do total de reads utilizados para $o$ término do cosmídeo.

Tabela 05: Distribuição de seqüências utilizadas na montagem e finalização do cosmídeo X0QV-08A03.

\begin{tabular}{|c|l|c|c|}
\hline Cosmídeo & \multicolumn{2}{|c|}{ Biblioteca } & $\%$ \\
\hline \multirow{3}{*}{ X0QV-08A03 } & Nebulização (N) & 446 & $40,0 \%$ \\
\cline { 2 - 4 } & Pontas (L ou R) & 2 & $0,2 \%$ \\
\cline { 2 - 4 } & Primers (W) & 4 & $0,4 \%$ \\
\cline { 2 - 4 } & TOTAL & $\mathbf{4 5 2}$ & $\mathbf{4 0 , 6} \%$ \\
\hline X0UT-07A07 & (A, B, C, E, K, L, Q ou R) & $\mathbf{3 2 4}$ & $\mathbf{2 9 , 1} \%$ \\
\hline X0JJ-09E09 & (A, B, C ou D) & $\mathbf{2 0 6}$ & $\mathbf{1 8 , 5} \%$ \\
\hline X0QR-07H04 & (C, E ou F) & $\mathbf{1 5}$ & $\mathbf{1 , 3} \%$ \\
\hline Shotgun & & $\mathbf{5 8}$ & $\mathbf{5 , 2} \%$ \\
\hline outros & & $\mathbf{5 9}$ & $\mathbf{5 , 3} \%$ \\
\hline TOTAL & & $\mathbf{1 1 1 4}$ & $\mathbf{1 0 0 \%}$ \\
\hline
\end{tabular}

Após a montagem e finalização do cosmídeo a taxa de erro final do inserto X0QV-08A03 foi de $0.01 / 10.000$ bp. Com a finalização pode-se então fazer uma comparação do mapa de restrição com as enzimas BamH I, EcoR I e Hind III, feito anteriormente ao seqüenciamento, e com o resultado dado pela digestão eletrônica do 
inserto. As bandas obtidas destas duas formas foram correspondentes, confirmando o seqüenciamento e montagem do cosmídeo.

\section{IV.1.4.Cosmídeo X0QV-03D03}

O cosmídeo X0QV-03D03 foi o quarto recebido pelo laboratório. Foi utilizada somente a metodologia de fragmentação mecânica por nebulização para a construção das sub-bibliotecas de plasmídeos, escolhendo-se fragmentos entre 1,3 e 2,3 Kb, clonados em sítio EcoR V do vetor pbSK.

Para a montagem e finalização deste cosmídeo de 39.433 pb foram utilizadas 1101 seqüências, distribuídas em 482 seqüências provenientes das bibliotecas construídas para o cosmídeo X0QV-03D03, do seqüenciamento de suas extremidades pela utilização dos primers do vetor Lawrist4, ou do seqüenciamento com utilização de primers construídos para o fechamento ou melhoria de qualidade do inserto; 495 seqüências provenientes de cosmídeos que se sobrepõem ao X0QV-03D03 (X0QV07B03, X0QR-07H04, X0RP-07B10 e X0UT-07A07); 79 das bibliotecas de "shotgun" genômico e 45 outras seqüências provenientes de outros cosmídeos. A distribuição das seqüências utilizadas na montagem e finalização do cosmídeo X0QV03D03 está esquematizada na tabela abaixo (Tabela 06).

Para este cosmídeo foram sintetizados somente 4 primers internos específicos, necessários para a obtenção de qualidade e características necessárias para o término do clone. 
Tabela 06: Distribuição de seqüências utilizadas na montagem e finalização do cosmídeo X0QV-03D03.

\begin{tabular}{|c|l|c|c|}
\hline \multirow{2}{*}{ Cosmídeo } & \multicolumn{2}{|c|}{ Biblioteca } & $\%$ \\
\hline \multirow{4}{*}{ X0QV-03D03 } & Nebulização (N) & 476 & $43,2 \%$ \\
\cline { 2 - 4 } & Pontas (L ou R) & 2 & $0,2 \%$ \\
\cline { 2 - 4 } & Primers (X ou Z) & 4 & $0,4 \%$ \\
\cline { 2 - 4 } & TOTAL & 482 & $\mathbf{4 3 , 8} \%$ \\
\hline \multirow{3}{*}{ X0QV-07B03 } & Alu I (A) & 21 & $1,9 \%$ \\
\cline { 2 - 4 } & Nebulização (N) & 163 & $14,8 \%$ \\
\cline { 2 - 4 } & Ponta (R) & 1 & $0,1 \%$ \\
\cline { 2 - 4 } & Primers (P ou X) & 16 & $1,4 \%$ \\
\cline { 2 - 4 } & TOTAL & $\mathbf{2 0 1}$ & $\mathbf{1 8 , 2} \%$ \\
\hline X0QR-07H04 & (C, E ou F) & $\mathbf{2 2 1}$ & $\mathbf{2 0 , 1} \%$ \\
\hline X0RP-07B10 & (A) & $\mathbf{5 0}$ & $\mathbf{4 , 5} \%$ \\
\hline X0UT-07A07 & (A, B, C, K, L ou Q) & $\mathbf{2 3}$ & $\mathbf{2 , 1} \%$ \\
\hline Shotgun & & $\mathbf{7 9}$ & $\mathbf{7 , 2} \%$ \\
\hline outros & & $\mathbf{4 5}$ & $\mathbf{4 , 1} \%$ \\
\hline TOTAL & & $\mathbf{1 1 0 1}$ & $\mathbf{1 0 0 \%}$ \\
\hline & & & \\
\hline
\end{tabular}

Após a montagem e finalização do cosmídeo a taxa de erro final do inserto X0QV-03D03 foi de $0.00 / 10.000$ bp. Com a finalização pode-se então fazer uma comparação do mapa de restrição com as enzimas BamH I, EcoR I e Hind III, feito anteriormente ao seqüenciamento, e com o resultado dado pela digestão eletrônica do inserto. As bandas obtidas destas duas formas foram correspondentes, confirmando o seqüenciamento e montagem do cosmídeo.

\section{IV.1.5. Cosmídeo X0QV-04A09}

O cosmídeo X0QV-04A09 foi o quinto recebido pelo laboratório. Este cosmídeo foi seqüenciado para ligar os cosmídeos X0QR-01H09 (grupo QR sob coordenação dos Profs.Drs. Fernando Reinach, Ana Claudia Rasera e Ronaldo Quaggio) e X0PM-01A01 (grupo PM sob coordenação do Prof. Dr. Marcelo R. S. Briones). O seqüenciamento das extremidades dos cosmídeos foi realizado pelo grupo 
CE (sob coordenação da Profa .Dra. Siu Mui Tsai), permitindo a escolha de tal cosmídeo.

Foi utilizada somente a metodologia de fragmentação mecânica por nebulização para a construção das sub-bibliotecas de plasmídeos, escolhendo-se fragmentos entre 1,3 e 2,3 Kb, clonados em sítio EcoR V do vetor pbSK.

Para a montagem e finalização deste cosmídeo de $38.656 \mathrm{pb}$ foram utilizadas 1272 seqüências, distribuídas em 782 seqüências provenientes das bibliotecas construídas para o cosmídeo X0QV-04A09, do seqüenciamento de suas extremidades pela utilização dos primers do vetor Lawrist4, ou do seqüenciamento com utilização de primer construído para o fechamento ou melhoria de qualidade do inserto; 393 seqüências provenientes de cosmídeos que se sobrepõem ao X0QV-04A09 (X0CE04A09, X0QR-01H09 e X0PM-01A01); 96 das bibliotecas de "shotgun" genômico e 1 seqüência proveniente de outro cosmídeo. A distribuição das seqüências utilizadas na montagem e finalização do cosmídeo X0QV-04A09 está esquematizada na tabela abaixo (Tabela 07).

Novamente, somente foram sintetizados 4 primers para o término deste cosmídeo, dentre os quais somente um foi utilizado no banco de dados construídos para o fechamento do inserto. 
Tabela 07: Distribuição de sequiências utilizadas na montagem e finalização do cosmídeo X0QV-04A09.

\begin{tabular}{|c|l|c|c|}
\hline \multirow{2}{*}{ Cosmídeo } & \multicolumn{2}{|c|}{ Biblioteca } & $\%$ \\
\hline \multirow{2}{*}{ X0QV-04A09 } & Nebulização (N) & 781 & $61,4 \%$ \\
\cline { 2 - 4 } & Primer (K) & 1 & $0,1 \%$ \\
\cline { 2 - 4 } & TOTAL & 782 & $61,5 \%$ \\
\hline X0CE-04A09 & Pontas (L) & 2 & $\mathbf{0 , 2} \%$ \\
\hline X0QR-01H09 & (C, D, E, F ou H) & 205 & $16,1 \%$ \\
\hline X0PM-01A01 & (A, B ou F) & 186 & $\mathbf{1 4 , 6} \%$ \\
\hline Shotgun & & 96 & $\mathbf{7 , 5} \%$ \\
\hline outros & & 1 & $\mathbf{0 , 2} \%$ \\
\hline TOTAL & & 1272 & $\mathbf{1 0 0 \%}$ \\
\hline
\end{tabular}

Após a montagem e finalização do cosmídeo a taxa de erro final do inserto X0QV-04A09 foi de $0.02 / 10.000$ bp. Com a finalização pode-se então fazer uma comparação do mapa de restrição com as enzimas BamH I, EcoR I e Hind III, feitos anteriormente ao seqüenciamento, com o resultado dado pela digestão eletrônica do inserto. As bandas obtidas destas duas formas foram correspondentes, confirmando o seqüenciamento e montagem do cosmídeo.

\section{IV.1.6. Cosmídeos X0QV-10F11 e X0QV-20F11}

O cosmídeo X0QV-10F11 foi o sexto a ser recebido pelo laboratório. Novamente foi utilizada somente a metodologia de fragmentação mecânica por nebulização para a construção das sub-bibliotecas de plasmídeos, escolhendo-se fragmentos entre 1,3 e 2,3 Kb, clonados em sítio EcoR V do vetor pbSK.

No decorrer de seu seqüenciamento percebeu-se que este representava uma quimera, sendo então subdividido em dois contigs, cada qual tratado como se fosse um cosmídeo diferente. A constatação de que tratava-se de uma quimera foi causada pelo fato de que uma das extremidades do inserto (cerca de $4 \mathrm{~kb}$ na extremidade do cosmídeo) fazia match com uma região distante do genoma, longa e já totalmente seqüenciada, na qual havia dois cosmídeos sobrepostos, não havendo dúvida da montagem naquela região. $\mathrm{O}$ contig maior, com $34.418 \mathrm{pb}$, continuou sendo 
denominado de X0QV-10F11 e o contig menor, com $4.437 \mathrm{pb}$, foi nomeado como $\mathrm{X} 0 \mathrm{QV}-20 \mathrm{~F} 11$. Os critérios de montagem e qualidade continuaram sendo aqueles descritos nos materiais e métodos, com a exceção da falta do vetor Lawrist4 em uma das extremidades do cosmídeo, cada qual apresentando agora uma extremidade Lawrist4 e outra faltante, denominada de "LOSTLAU".

Geralmente a presença de quimeras é constatada pela existência de trechos de seqüência do vetor Lawrist4 dentro do inserto. No caso do cosmídeo X0QV-10F11 não foi observado tal fato. $O$ observado foi que as extremidades do inserto do cosmídeo correspondiam à duas regiões muito distantes, pertencentes à outros cosmídeos já presentes e caracterizados no banco de dados geral. $O$ fragmento denominado posteriormente de X0QV-10F11 foi localizado em uma região altamente seqüenciada, confirmada pela sobreposição de 4 cosmídeos (07B08, 01G04, 07A12 e 03C11), afastando a possibilidade de montagem genômica errada. $\mathrm{O}$ fragmento menor denominado de X0QV-20F11 foi localizado em uma região totalmente interior à outro cosmídeo já presente no banco de dados (07A08).

Para a montagem e finalização do cosmídeo X0QV-10F11 foram utilizadas 1183 seqüências, distribuídas em 343 seqüências provenientes da biblioteca construída para o cosmídeo X0QV-10F11 e do seqüenciamento de sua extremidade pela utilização do primer do vetor Lawrist4; 696 seqüências provenientes de cosmídeos que se sobrepõem ao X0QV-10F11 (X0PM-07B08, X0**-01G04 e X0MR-07A12) e 144 das bibliotecas de "shotgun" genômico.

Para a montagem e finalização do cosmídeoX0QV-20F11 foram utilizadas 138 seqüências, distribuídas em 38 seqüências provenientes da biblioteca construída para o cosmídeo X0QV-10F11, 1 seqüência da extremidade do inserto pela utilização do primer do vetor Lawrist4; 1 seqüência de extremidade realizada pelo grupo IL (sob coordenação do Prof.Dr. Andrew Simpson); 94 seqüências provenientes do cosmídeo que se sobrepõe ao X0QV-20F11 (X0RC-07A08) e 5 seqüências das bibliotecas de "shotgun" genômico.

A distribuição das seqüências utilizadas na montagem e finalização dos cosmídeos X0QV-10F11 e X0QV-20F11 estão esquematizadas nas tabelas abaixo (Tabelas 08 e 09). Observar que para a tabela do cosmídeo X0QV-20F11 os clones foram nomeados como pertencentes ao X0QV-10F11, uma vez que a separação dos contigs ou cosmídeos se deu somente após o seqüenciamento dos clones provenientes da biblioteca construída, todos denominados X0QV-10F11): 
Tabela 08: Distribuição de seqüências utilizadas na montagem e finalização do cosmídeo X0QV-10F11.

\begin{tabular}{|c|l|c|c|}
\hline Cosmídeo & \multicolumn{2}{|c|}{ Biblioteca } & $\%$ \\
\hline \multirow{2}{*}{ X0QV-10F11 } & Nebulização (N) & 342 & $28,9 \%$ \\
\cline { 2 - 4 } & Ponta (R) & 1 & $0,1 \%$ \\
\cline { 2 - 4 } & TOTAL & 343 & $29,0 \%$ \\
\hline X0PM-07B08 & (A e F) & 311 & $26,3 \%$ \\
\hline X0IU-01G04 & (G, T, V, X ou Y) & 238 & $20,1 \%$ \\
\hline X0BG-01G04 & (A, B, C, D, E, F, G ou H) & 132 & $11,1 \%$ \\
\hline X0MR-07A12 & (A) & 15 & $1,3 \%$ \\
\hline Shotgun & & 144 & $12,2 \%$ \\
\hline TOTAL & & 1183 & $100 \%$ \\
\hline
\end{tabular}

Tabela 09: Distribuição de seqüências utilizadas na montagem e finalização do cosmídeo X0QV-20F11.

\begin{tabular}{|c|l|c|c|}
\hline \multirow{2}{*}{ Cosmídeo } & \multicolumn{2}{|c|}{ Biblioteca } & $\%$ \\
\hline \multirow{3}{*}{ X0QV-10F11 } & Nebulização (N) & 37 & $26,8 \%$ \\
\cline { 2 - 4 } & Ponta (L) & 1 & $0,7 \%$ \\
\cline { 2 - 4 } & TOTAL & 38 & $27,5 \%$ \\
\hline X0IL-10F11 & (L) & 1 & $\mathbf{0 , 7} \%$ \\
\hline X0RC-07A08 & (A ou B) & 94 & $\mathbf{6 8 , 1} \%$ \\
\hline Shotgun & & 5 & $3,7 \%$ \\
\hline TOTAL & & 138 & $100 \%$ \\
\hline
\end{tabular}

Após a montagem e finalização do cosmídeo a taxa de erro foi de $0.00 /$ 10.000 bp para ambos os cosmídeos. Devido à montagem em dois cosmídeos separados, não foram possíveis as comparações dos padrões de bandeamento das digestões feitas anteriormente ao início do seqüenciamento do cosmídeo e as eletrônicas. 


\section{IV.1.7. Cosmídeo X0QV-06H03}

O sétimo e último cosmídeo recebido foi denominado de $\mathrm{X} 0 \mathrm{QV}-06 \mathrm{H} 03$ e X0UV-06H03, uma vez que foi realizado em conjunto com o laboratório UV sob coordenação do Prof. Dr. Arthur Gruber. As extremidades deste inserto foram primeiramente sequienciadas pelos laboratórios IL (Prof.Dr. Andrew Simpson) e MC (Prof.Dr. Luiz R. Nunes) na tentativa de se encontrar novos cosmídeos que cobrissem os "gaps" ou extendessem contigs já existentes. $O$ seqüenciamento deste cosmídeo possibilitou a extensão do contig que possuía em sua extremidade o cosmídeo X0QS07H02 (Profa.Dra. Suely Lopes Gomes).

Foi utilizada somente a metodologia de fragmentação mecânica por nebulização para a construção das sub-bibliotecas de plasmídeos, escolhendo-se fragmentos entre 1,3 e 2,3 Kb, clonados em sítio EcoR $\mathrm{V}$ do vetor pbSK. A construção da sub-biblioteca utilizada para o seqüenciamento do cosmídeo $\mathrm{X} 0^{* *}$ 06H03 foi realizada em nosso laboratório e clones doados ao grupo UV.

Para a montagem e finalização deste cosmídeo de $38.656 \mathrm{pb}$ foram utilizadas 1417 seqüências, distribuídas em 776 seqüências provenientes das bibliotecas construídas para o cosmídeo $\mathrm{X} 0{ }^{* *}-04 \mathrm{~A} 09$ e do seqüenciamento de suas extremidades pela utilização dos primers do vetor Lawrist4; 4 seqüencias de extremidades feitas por outros laboratórios (IL e MC); 467 sequiências provenientes de cosmídeo que se sobrepõe ao $\mathrm{X} 0{ }^{* *}-06 \mathrm{H} 03$ (X0QS-07H02) e 170 seqüências das bibliotecas de "shotgun" genômico. A distribuição das seqüências utilizadas na montagem e finalização do cosmídeo X0**-06H03 está esquematizada na tabela abaixo (Tabela 10).

Para este último cosmídeo seqüenciado no laboratório, em colaboração com o laboratório UV (Arthur Grüber) não houve a necessidade de síntese de nenhum primer interno, bastando o seqüenciamento extensivo de clones provenientes das subbibliotecas randômicas construídas, da utilização de reads seqüenciados por outro grupo devido à sobreposição de cosmídeos e de reads provenientes das bibliotecas de "shotgun" genômico. 
Tabela 10: Distribuição de seqüências utilizadas na montagem e finalização do cosmídeo $\mathrm{X} 0 * *-06 \mathrm{H} 03$.

\begin{tabular}{|c|l|c|c|}
\hline Cosmídeo & \multicolumn{2}{|c|}{ Biblioteca } & $\%$ \\
\hline \multirow{2}{*}{ X0QV-06H03 } & Nebulização (N) & 309 & $21,8 \%$ \\
\cline { 2 - 4 } & Pontas (L ou R) & 3 & $0,2 \%$ \\
\cline { 2 - 4 } & TOTAL & 312 & $\mathbf{2 2 , 0} \%$ \\
\hline X0UV-06H03 & (C ou V) & 464 & $\mathbf{3 2 , 8} \%$ \\
\hline X0IL-06H03 & (L) & 2 & $\mathbf{0 , 1} \%$ \\
\hline X0MC-06H03 & (L) & 2 & $\mathbf{0 , 1} \%$ \\
\hline X0QS-07H02 & (C, L, M ou N) & $\mathbf{4 6 7}$ & $\mathbf{3 3 , 0} \%$ \\
\hline Shotgun & & $\mathbf{1 7 0}$ & $\mathbf{1 2 , 0} \%$ \\
\hline TOTAL & & $\mathbf{1 4 1 7}$ & $\mathbf{1 0 0 \%}$ \\
\hline
\end{tabular}

Após a montagem e finalização do cosmídeo a taxa de erro final do inserto X0**-06H03 foi de $0.00 / 10.000 \mathrm{bp}$. Com a finalização pode-se então fazer uma comparação do mapa de restrição com as enzimas BamH I, EcoR I e Hind III, feito anteriormente ao seqüenciamento, com o resultado dado pela digestão eletrônica do inserto. As bandas obtidas destas duas formas foram correspondentes, confirmando o seqüenciamento e montagem do cosmídeo. 


\section{IV.2. Bibliotecas de "shotgun" genômico.}

Após as primeiras tentativas frustradas de obtenção de bibliotecas de "shotgun" randômico no início do projeto (bibliotecas 00 e 03), tal metodologia foi retomada para cobrir "gaps" existentes no genoma os quais não estavam clonados em cosmídeos, mostrando-se de grande valia para o preenchimento de tais regiões.

Nosso grupo recebeu placas de clones de bibliotecas de "shotgun" genômico por nebulização, provenientes das bibliotecas denominadas 07, 08, 10 e 15 como mostra tabela abaixo (Tabela 11):

Tabela 11: Descrição das bibliotecas de "shotgun" genômico seqüenciadas pelo grupo X0QV.

\begin{tabular}{|c|l|l|c|}
\hline Biblioteca & \multicolumn{1}{|c|}{ Vetor } & \multicolumn{1}{|c|}{ Inserto } & Grupo responsável \\
\hline 07 & pUC 18 / sítio Sma I & Nebulização total & JE \\
\hline 08 & pUC 18 / sítio Sma I & Nebulização total $(1,5$ a 2,5 Kb) & JE \\
\hline 10 & pUC 18 / sítio Sma I & Nebulização total $(2,0$ a 4,0 Kb) & JE \\
\hline 15 & pUC 18 / sítio Sma I & Nebulização total & $\mathrm{IL}$ \\
\hline
\end{tabular}

O número total de seqüências obtidas para cada biblioteca, o número de bases obtidas para cada uma, o número e percentagem de reads (seqüências) aceitas pelos critérios pré-estabelecidos são mostrados na tabela abaixo (Tabela 12):

Tabela 12: Distribuição de seqüências provenientes das bibliotecas de "shotgun" genômico seqüenciadas em nosso laboratório.

\begin{tabular}{|c|c|c|c|c|}
\hline Biblioteca & \# seqüências & \# bases & $\begin{array}{c}\text { \# reads aceitos ( } \geq 200 \text { bp } \\
\text { e phred } \geq \mathbf{2 0})\end{array}$ & \% reads aceitos \\
\hline 07 & 184 & 56.488 & 166 & $90 \%$ \\
\hline 08 & 450 & 120.689 & 332 & $73 \%$ \\
\hline 10 & 655 & 218.012 & 594 & $90 \%$ \\
\hline 15 & 94 & 24.117 & 65 & $69 \%$ \\
\hline TOTAL & $\mathbf{1 3 8 3}$ & $\mathbf{4 1 9 . 3 0 6}$ & $\mathbf{1 1 5 7}$ & $\mathbf{8 4} \%$ \\
\hline
\end{tabular}




\section{IV.3. Clones "shotgun" - GFSs ("gap filling sequences)}

Outra estratégia utilizada para o fechamento de "gaps" existentes no genoma da bactéria Xylella fastidiosa foi o seqüenciamento completo de clones provenientes das bibliotecas de "shotgun" genômico. Estes clones foram escolhidos por estarem fisicamente nas extremidades de contigs existentes, ou para melhorar a qualidade de determinada região do genoma da bactéria.

A obtenção de sub-bibliotecas desses clones está descrita em Materiais e Métodos, e os clones completamente seqüenciados em nosso laboratório são descritos na tabela abaixo (Tabela 13):

Tabela 13: Clones provenientes das bibliotecas de "shotgun" genômico totalmente seqüenciados em nosso laboratório, utilizados no preenchimento de "gaps" e melhoria de qualidade de regiões do genoma do fitopatógeno.

\begin{tabular}{|c|c|c|c|}
\hline Clone & Nome GFSs & \# reads & \# bases \\
\hline X0QV0010C05 & X0QV-00J67 & 68 & 1.472 \\
\hline X0QV0010G03 & X0QV-00J18 & 55 & 2.805 \\
\hline X0QV0724G04 & X0QV-07J24 & 1 & 1.989 \\
\hline X0QV1034E07 & X0QV-00J34 & 37 & 2.169 \\
\hline X0QV1034H11 & X0QV-00J53 & 41 & 2.710 \\
\hline X0QV1064D09 & X0QV-10J64 & 36 & 2.097 \\
\hline X0QV1067G10 & X0QV-00J19 & 33 & 2.601 \\
\hline TOTAL & & $\mathbf{2 7 1}$ & $\mathbf{1 5 . 8 4 3}$ \\
\hline
\end{tabular}




\section{IV.4. Biblioteca RDA ("representational difference analysis")}

A metodologia de RDA (Representational difference analysis) foi primeiramente utilizada para descobrir pequenas diferenças entre duas populações de DNA ou entre genomas. Em 1984, Lamar e Palmer utilizaram uma técnica de hibridização subtrativa isolando sondas para o cromossomo Y (48) e posteriormente muitos outros pesquisadores se utilizaram de tal técnica para clonar sondas para diversas doenças, sempre sempre baseado em diferenças existentes nos diversos casos. (54).

Para o projeto genoma Xylella fastidiosa esta metodologia de subtração foi utilizada para preenchermos os "gaps" ainda existentes no decorrer do projeto. Utilizando-se de fragmentos obtidos por digestão do genoma (tester) e dos cosmídeos (driver) foi realizada uma subtração, resultando na amplificação e clonagem das regiões do genoma ainda não representados pelos cosmideos.

As denominadas bibliotecas de RDA foram feitas pelo Dr. Hoheizel em Heidelberg, Alemanha. Subdividiram-se em 4 outras bibliotecas abaixo descritas:

- AS: tanto o DNA genômico (tester) quanto todos os cosmídeos existentes no projeto (driver) foram digeridos com a enzima de restrição SaulII A.

- $\mathrm{AB}$ : tanto o DNA genômico (tester) quanto todos os cosmídeos existentes no projeto (driver) foram digeridos com a enzima de restrição BamH I.

- CS: tanto o DNA genômico (tester) quanto um set de 81 cosmídeos (que no momento cobriam a maior extensão possível do genoma - driver) do projeto foram digeridos com a enzima de restrição SauIII A.

- CB: tanto o DNA genômico (tester) quanto um set de 81 cosmídeos (que no momento cobriam a maior extensão possível do genoma - driver) do projeto foram digeridos com a enzima de restrição BamH I.

Uma listagem dos 81 cosmídeos seqüenciados no projeto e utilizados como driver na construção das bibliotecas CS e CB se encontra no Apêndice.

Os fragmentos gerados por tais digestões foram selecionados em seu tamanho: de 100 a $1000 \mathrm{pb}$ (para as bibliotecas AS e CS) e de 1500 bp a 2500 bp (para as bibliotecas $\mathrm{AB}$ e $\mathrm{CB}$ ), clonadas em vetor Promega pGEM-T easy e inseridas em cepas bacterianas DH10B. 
Para a obtenção dos templates necessários ao seqüenciamento foram utilizadas as metodologias de Boiling prep e PCR de colônia como descritas no Materiais e Métodos, bem como o seqüenciamento de tais clones.

O laboratório recebeu um total de 384 clones provenientes da biblioteca AS, seqüenciando no total 247 destes clones (64,3\%), totalizando $77.575 \mathrm{bp}$. De acordo com os critérios de qualidade pré-estabelecidos pela coordenação do projeto (seqüências de pelo menos $200 \mathrm{pb}$ com qualidade dada pelo phred sendo maior ou igual à 20), 234 dos 247 clones enviados foram aceitos, uma eficiência de $94 \%$. 


\section{IV.5. Anotação}

Com o andamento do projeto e finalização dos primeiros cosmídeos, iniciou-se a anotação destas regiôes já seqüenciadas. Uma anotação consiste em uma atribuição de uma função hipotética para as ORFs preditas (Materiais e Métodos) de acordo com a similaridade e \% de cobertura que a sequiência protéica obtida da tradução da ORF tem com um seqüência de uma proteína já conhecida em um banco de dados.

Para a realização desta primeira anotação foram distribuídas regiões do genoma representando cosmídeos, ou seja, os cosmídeos.

Nosso laboratório realizou a anotação de 7 cosmídeos em uma extensão aproximada de $210 \mathrm{~Kb}$ do genoma de Xylella fastidiosa apresentando 290 ORFs ("open reading frames" ou fases abertas de leitura)

Os cosmídeos anotados foram provenientes de nosso (X0QV-03D03, X0QV07B03 e X0QV-08A03) e de outros laboratórios (X0RP-06C06, X0QR-07H04, X0JJ09E09 e X0PF-09G12), escolhidos desta forma por pertencerem à uma região linear do genoma coberta por tais cosmídeos (Figura 08).

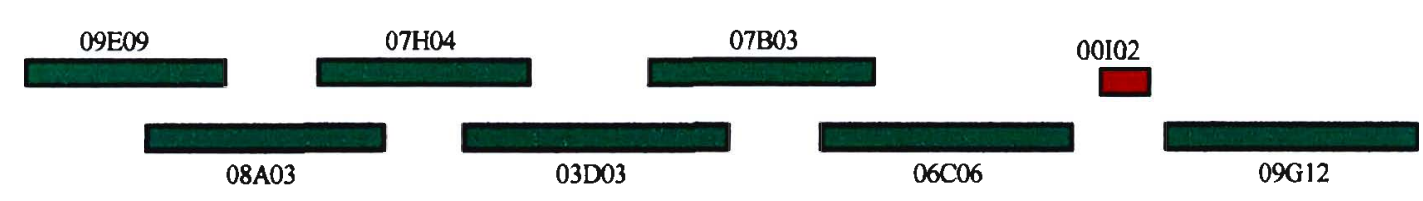

Figura 08: Alinhamento físico dos cosmídeos anotados. A região vermelha corresponde à um "gap" seqüenciado pelo grupo IL.

O tamanho do inserto e da sobreposição com outro cosmídeo, bem como o número de pares de base, ORFs preditas e anotadas é listado na tabela abaixo (Tabela 14): 
Tabela 14: Descrição dos cosmídeos anotados em nosso laboratório.

\begin{tabular}{|l|c|c|c|c|}
\hline Cosmídeo & $\begin{array}{c}\text { Tamanho } \\
\text { (bp) }\end{array}$ & $\begin{array}{c}\text { Sobreposição bp } \\
\text { (c/ cosmídeo) }\end{array}$ & $\begin{array}{c}\text { \# ORFs } \\
\text { preditas }\end{array}$ & $\begin{array}{c}\text { \# ORFs } \\
\text { anotadas }\end{array}$ \\
\hline X0JJ-09E09 & 36.814 & - & 46 & 46 \\
\hline X0QV-08A03 & 38.066 & $15.528(09 \mathrm{E} 09)$ & 40 & 27 \\
\hline X0QR-07H04 & 39.395 & $7.111(08 \mathrm{A03})$ & 42 & 38 \\
\hline X0QV-03D03 & 39.433 & $14.155(07 \mathrm{H} 04)$ & 47 & 32 \\
\hline X0QV-07B03 & 39.278 & $13.167(03 \mathrm{D} 03)$ & 53 & 38 \\
\hline X0QV-06C06 & 50.172 & $21.919(07 \mathrm{~B} 03)$ & 84 & 52 \\
\hline X0PF-09G12 & 39.806 & - & 59 & 59 \\
\hline TOTAL & $\mathbf{2 8 2 . 9 6 4}$ & $\mathbf{7 1 . 8 8 0}$ & 371 & 292 \\
\hline
\end{tabular}

A diferença encontrada entre o número de ORFs preditas e o de ORFs anotadas corresponde ao fato da sobreposição entre os cosmídeos (Figura 08), fazendo com que as ORFs presentes em dois cosmídeos sobrepostos fossem anotadas somente uma vez.

De acordo com os critérios descritos em Materiais e Métodos (pág 41), as ORFs preditas foram anotadas, sendo que algumas destas, por não corresponderem à proteínas específicas (hipotéticas) e serem sobrepostas à ORFs hipotéticas de maior tamanho ou de função determinada, foram excluídas do banco de dados de ORFs de Xylella fastidiosa. Como exemplo podemos notar na Tabela 15, as ORFs denominadas de XF-09E09-g107, g108, g109 e g110 foram excluídas do banco de dados do projeto. $\mathrm{O}$ motivo pode ser verificado quando observamos a Figura 09 (pág.69) notando nitidamente uma sobreposição de tais ORFs preditas à ORF XF09E09-g111. Tal ORF, apesar de também caracterizar uma proteína hipotética possui um tamanho superior às outras excluídas e por isso permaneceu no banco de dados.

Podemos observar casos também em que a proteína hipotética foi excluída por estar sobreposta à outra $\mathrm{ORF}$ na qual foi possível a predição de sua possível função. $\mathrm{O}$ exemplo também pode ser dado pela Tabela de ORFs preditas para o cosmídeo 
X0QV-09E09 onde a ORF XF-09E09-gl17 foi excluída em virtude de sobreposição à ORF XF-09E09-gl18 predita como sendo uma lipoproteína.

As tabelas e figuras seguintes listam as ORFs preditas e anotadas para cada cosmídeo, mostrando os códigos dados a tais ORFs, a proteína de maior similaridade no banco de dados e o organismo referente pela busca realizada através do BLASTp, o seu código no GenBank (gi) ou no SwissProt (sp), a probabilidade para a similaridade ser ao acaso (E-value), a $\%$ de cobertura da possível proteína correspondente em GenBank pela ORF predita e a categoria na qual tais ORFs foram enquadradas em Xylella fastidiosa. Características como e-value, $\%$ de cobertura e possíveis presenças de operons são essenciais para a predição correta e embasamento das decisões das ORFs preditas no genoma do fitopatógeno, sendo comentadas a seguir.

Uma predição de função para ser consistente deve se embasar primeiramente na grande similaridade da ORF com a proteína presente no banco de dados. Tal fato pode ser observado pelo número de e-value onde, quanto menor for o valor, maior será a probabilidade de similaridade real entre as seqüências comparadas (uma vez que tal valor corresponde à probabilidade do alinhamento ter ocorrido ao acaso). Em todas as tabelas demonstradas abaixo podemos ter exemplos de baixos valores de evalue (XF-09E09-g103, XF-08A03-g134, XF-07H04-g120 entre outros) auxiliando na anotação mais precisa de tais ORFs.

Uma preocupação constante de toda equipe de anotação do projeto foi a definição de nomenclatura de todas as ORFs inseridas no banco de dados de Xylella fastidiosa. Como as anotações foram feiras baseando-se somente na seqüência do fitopatógeno, ou seja, não foram realizados experimentos bioquímicos, tomou-se o cuidado da inserção da palavra Putative antes de qualquer atribuição da função hipotética de cada ORF. Por exemplo, na tabela abaixo verificamos a possível presença de uma "Cystathionine gamma-synthase" (XF0864) em Xylella fastidiosa devido à sua similaridade com tal proteína em Escherichia coli (e-value de e-105 e uma \% de cobertura de 98\%). Tal ORF foi então anotada como sendo uma "Putative cystathionine gamma-synthase". Erros propagativos podem se dar quando se admite a presença de determinada proteína em um organismo pouco conhecido e recémseqüenciado. Predições ou considerações errôneas de um anotador que constem nos bancos de dados públicos utilizados para análises de posteriores genomas podem ser propagados indefinidamente, levando à conclusões enganosas e erradas. 
Casos existiram em que uma ORF, apesar de inicialmente ser considerada (computacionalmente) como sendo uma determinada proteína, não foi assim descrita pelos anotadores em vista das evidências e considerações feitas por tais. Um exemplo pode ser visto na Tabela 14: a ORF denominada de XF-09E09-g105 foi considerada inicialmente como uma "possible secreted peptidase" com um e-value de 2e-12. Como possuía apenas matchs parciais com as peptidases, ou seja, uma baixa \% de cobertura (49\%), não foi caracterizada como sendo uma peptidase e sim uma proteína hipotética e seu peso molecular foi calculado.

Tais fatos revelam a importância da intervenção humana a despeito de todas as novas tecnologias computacionais empregadas. Ainda assim, a anotação é passivel de erros. Como exemplo podemos verificar a ORF XF-09E09-gl24 (XF0853) que foi caracterizada como "two-component system, sensor protein" devido ao baixo e-value (5e-47). Sua \% de cobertura porém se mostrou baixa (51\%) como no caso comentado acima para a ORF XF-09E09-g105 e deve ser revista para possível correção.

Tabela 15: ORFs anotadas no cosmídeo X0JJ-09E09. As ORFs marcadas em vermelho foram excluídas do banco de dados de ORFs de Xylella fastidiosa.

\begin{tabular}{|c|c|c|c|c|c|c|c|}
\hline \multicolumn{2}{|c|}{ ORFs } & \multirow{2}{*}{$\begin{array}{c}\text { Proteína } \\
\text { Hypothetical } \\
6,8 \mathrm{k} \text { Da protein }\end{array}$} & \multirow[t]{2}{*}{ Organismo } & \multirow[t]{2}{*}{ Código \# } & \multirow{2}{*}{$\begin{array}{l}\text { E-value } \\
\text { (Blastp) }\end{array}$} & \multirow{2}{*}{$\begin{array}{c}\% \\
\text { cobert. }\end{array}$} & \multirow{2}{*}{$\begin{array}{l}\text { Cat. } \\
\text { VIII.B }\end{array}$} \\
\hline XF-09E09-gl01 & & & & & & & \\
\hline XF-09E09-g102 & & $\begin{array}{l}\text { Hypothetical } \\
4,6 \mathrm{kDa} \text { protein }\end{array}$ & & & & & VIII.B \\
\hline XF-09E09-g103 & XF0864 & $\begin{array}{l}\text { Cystathionine } \\
\text { gamma-synthase }\end{array}$ & $\begin{array}{l}\text { Escherichia } \\
\text { coli }\end{array}$ & \begin{tabular}{l|l} 
sp & $P 00935$
\end{tabular} & e-105 & $98 \%$ & II.A.2 \\
\hline $\mathrm{XF-09E09-gl04}$ & XF0863 & $\begin{array}{l}\text { homoserine } \mathrm{O}- \\
\text { acetyltransferase }\end{array}$ & $\begin{array}{l}\text { Thermus } \\
\text { thermophilus }\end{array}$ & \begin{tabular}{l|l} 
gi & 6681415
\end{tabular} & $1 \mathrm{e}-26$ & $86 \%$ & II.A.2 \\
\hline XF-09E09-g105 & XF0862 & $\begin{array}{l}\text { Hypothetical } \\
\text { 29,6kDa protein } \\
\end{array}$ & & & & & VIII.B \\
\hline XF-09E09-gl06 & XF0861 & $\begin{array}{l}\text { Hypothetical } \\
9,9 \mathrm{kDa} \text { protein }\end{array}$ & & & & & VIII.B \\
\hline XF-09E09-gl07 & & $\begin{array}{l}\text { Hypothetical } \\
5,4 \mathrm{kDa} \text { protein }\end{array}$ & & & & & VIII.B \\
\hline XF-09E09-g108 & & $\begin{array}{l}\text { Hypothetical } \\
4,4 \mathrm{kDa} \text { protein }\end{array}$ & & & & & VIII.B \\
\hline XF-09E09-g109 & & $\begin{array}{l}\text { Hypothetical } \\
5,3 \mathrm{kDa} \text { protein }\end{array}$ & & & & & VIII.B \\
\hline XF-09E09-gl10 & & $\begin{array}{l}\text { Hypothetical } \\
6,2 \mathrm{kDa} \text { protein }\end{array}$ & & & & & VIII.B \\
\hline XF-09E09-gl11 & XF0860 & $\begin{array}{l}\text { Hypothetical } \\
27,2 \mathrm{kDa} \text { protein }\end{array}$ & & & & & VIII.B \\
\hline XF-09E09-g112 & XF0859 & $\begin{array}{l}\text { Hypothetical } \\
9,5 \mathrm{kDa} \text { protein }\end{array}$ & & & & & VIll.B \\
\hline
\end{tabular}




\begin{tabular}{|c|c|c|c|c|c|c|c|}
\hline XF-09E09-gl13 & & $\begin{array}{l}\text { Hypothetical } \\
5,7 \mathrm{kDa} \text { protein }\end{array}$ & & & & & VIII.B \\
\hline $\mathrm{XF}-09 \mathrm{E} 09-\mathrm{gl} 14$ & XF0858 & $\begin{array}{l}\text { Survival protein } \\
\text { (surE) }\end{array}$ & $\begin{array}{l}\text { Legionella } \\
\text { pneumophila }\end{array}$ & gi|5771428 & $4 e-79$ & $96 \%$ & VII.G \\
\hline $\mathrm{XF}-09 \mathrm{E} 09-\mathrm{g} \mid 15$ & XF0857 & $\begin{array}{l}\text { L-isoaspartate O- } \\
\text { methyltransferase }\end{array}$ & $\begin{array}{l}\text { Escherichia } \\
\text { coli }\end{array}$ & sp|P24206 & $7 e-40$ & $99 \%$ & III.C. 1 \\
\hline $\begin{array}{l}\mathrm{XF}-09 \mathrm{E} 09-\mathrm{gl} 16 \\
\end{array}$ & XF0856 & $\begin{array}{l}\text { Conserved } \\
\text { hypothetical } \\
\text { protein }\end{array}$ & $\begin{array}{l}\text { Haemophilus } \\
\text { somnus }\end{array}$ & sp|P36684 & $2 \mathrm{e}-25$ & $100 \%$ & VIII.A \\
\hline$\overline{\mathrm{XF}-09 \mathrm{E} 09-\mathrm{gl} 117}$ & & $\begin{array}{l}\text { Hypothetical } \\
4,3 \mathrm{kDa} \text { protein }\end{array}$ & & & & & VIII.B \\
\hline XF-09E09-gl18 & XF0855 & $\begin{array}{l}\text { Lipoprotein } \\
\text { (nlpD or IppB) }\end{array}$ & $\begin{array}{l}\text { Pseudomonas } \\
\text { aeruginosa }\end{array}$ & $\mathrm{sp} \mid \mathrm{P} 45682$ & $6 e-35$ & $92 \%$ & IV.B \\
\hline $\mathrm{XF}-09 \mathrm{E} 09-\mathrm{g} 119$ & & $\begin{array}{l}\text { Hypothetical } \\
5,2 \mathrm{kDa} \text { protein }\end{array}$ & & & & & VIII.B \\
\hline$\overline{\mathrm{XF}-09 \mathrm{E} 09-\mathrm{gl} 20}$ & & $\begin{array}{l}\text { Hypothetical } \\
\text { 13kDa protein }\end{array}$ & & & & & VIII.B \\
\hline 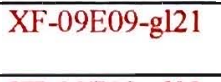 & & $\begin{array}{l}\text { Hypothetical } \\
\text { 4kDa protein }\end{array}$ & & & & & VIII.B \\
\hline $\begin{array}{l}\mathrm{XF}-09 \mathrm{E} 09-\mathrm{gl} 22 \\
\end{array}$ & & $\begin{array}{l}\text { Hypothetical } \\
5,5 \mathrm{kDa} \text { protein }\end{array}$ & & & & & VIII.B \\
\hline $\mathrm{XF}-09 \mathrm{E} 09-\mathrm{gl} 23$ & & $\begin{array}{l}\text { Hypothetical } \\
5,6 \mathrm{kDa} \text { protein }\end{array}$ & & & & & VIII.B \\
\hline XF-09E09-gl24 & XF0853 & $\begin{array}{l}\text { two-component } \\
\text { system, sensor } \\
\text { protein }\end{array}$ & $\begin{array}{l}\text { Calothrix } \\
\text { viguieri }\end{array}$ & gi|2765035 & $5 e-47$ & $51 \%$ & I.D \\
\hline XF-09E09-gl25 & & $\begin{array}{l}\text { Hypothetical } \\
4,6 \mathrm{kDa} \text { protein }\end{array}$ & & & & & VIIII.B \\
\hline$\overline{\mathrm{XF}-09 \mathrm{E} 09-\mathrm{gl} 26}$ & & $\begin{array}{l}\text { Hypothetical } \\
8,9 \mathrm{kDa} \text { protein }\end{array}$ & & & & & VIII.B \\
\hline $\mathrm{XF}-09 \mathrm{E} 09-\mathrm{g} \mid 27$ & XF0852 & $\begin{array}{l}\text { Alanine racemase } \\
\text { (ALR) }\end{array}$ & $\begin{array}{l}\text { Salmonella } \\
\text { typhimurium }\end{array}$ & sp|P06655 & $1 e-68$ & $100 \%$ & $\begin{array}{l}\text { IV.B } \\
\text { I.A.2 }\end{array}$ \\
\hline XF-09E09-gl28 & XF0851 & $\begin{array}{l}\text { D-amino acid } \\
\text { dehydrogenase } \\
\text { subunit }\end{array}$ & $\begin{array}{l}\text { Escherichia } \\
\text { coli }\end{array}$ & sp|P2901I & $e-126$ & $100 \%$ & $\begin{array}{l}\text { IV.A.1 } \\
\text { I.A.2 }\end{array}$ \\
\hline XF-09E09-gl29 & $\mathrm{XF} 0850$ & $\begin{array}{l}\text { Hypothetical } \\
7,5 \mathrm{kDa} \text { protein }\end{array}$ & & & & & VIII.B \\
\hline $\mathrm{XF}-09 \mathrm{E} 09-\mathrm{gl} 30$ & XF0849 & $\begin{array}{l}\text { Conserved } \\
\text { hypothetical } \\
\text { protein }\end{array}$ & $\begin{array}{l}\text { Escherichia } \\
\text { coli }\end{array}$ & sp|P39903 & 1e-32 & $87 \%$ & VIII.A \\
\hline $\mathrm{XF-09E09-g131}$ & XF0848 & $\begin{array}{l}\text { Conserved } \\
\text { hypothetical } \\
\text { protein (YAAH) }\end{array}$ & $\begin{array}{l}\text { Bacillus } \\
\text { subtilis }\end{array}$ & sp|P37531 & $9 e-27$ & $54 \%$ & VII.A \\
\hline $\mathrm{XF}-09 \mathrm{E} 09-\mathrm{gl} 132$ & $\mathrm{XF0847}$ & $\begin{array}{l}\text { Beta- } \\
\text { hexosaminidase } \\
\text { precursor } \\
\text { (NAHA) }\end{array}$ & $\begin{array}{l}\text { Porphyromona } \\
\text { s gingivalis }\end{array}$ & sp|P49008 & $e-103$ & $74 \%$ & IV.A.2 \\
\hline $\mathrm{XF}-09 \mathrm{E} 09-\mathrm{gl} 33$ & $\mathrm{XF} 0846$ & $\begin{array}{l}\text { Beta- } \\
\text { mannosidase } \\
\text { precursor } \\
\text { (TM1624) }\end{array}$ & $\begin{array}{l}\text { Thermotoga } \\
\text { maritima }\end{array}$ & gi|4982197 & $1 \mathrm{e}-108$ & $83 \%$ & I.A.2 \\
\hline $\mathrm{XF}-09 \mathrm{E} 09-\mathrm{gl} \mid 34$ & XF0845 & $\begin{array}{l}\text { family } 3 \\
\text { glycoside } \\
\text { hydrolase (xylA) }\end{array}$ & $\begin{array}{l}\text { Ruminococcus } \\
\text { flovefaciens }\end{array}$ & gi|5690010 & $2 e-80$ & & Vll.D \\
\hline XF-09E09-g135 & & $\begin{array}{l}\text { Hypothetical } \\
5,5 \mathrm{kDa} \text { protein }\end{array}$ & & & & & VIIII.B \\
\hline XF-09E09-g136 & XF0844 & $\begin{array}{l}\text { Hypothetical } \\
\text { 9,4kDa protein }\end{array}$ & & & & & VIII.B \\
\hline XF-09E09-gl37 & XF0843 & $\begin{array}{l}\text { Conserved } \\
\text { hypothetical } \\
\text { protein }\end{array}$ & $\begin{array}{l}\text { Schizasaccharo } \\
\text { myces pombe }\end{array}$ & sp|Q10449 & $9 \mathrm{e}-89$ & $90 \%$ & $\begin{array}{l}\text { VIII.A } \\
\end{array}$ \\
\hline
\end{tabular}




\begin{tabular}{|c|c|c|c|c|c|c|c|}
\hline XF-09E09-g]38 & XF0842 & $\begin{array}{l}\text { Conserved } \\
\text { hypothetical } \\
\text { protein }\end{array}$ & $\begin{array}{l}\text { Streptomyces } \\
\text { coelicolor } \\
\text { A3(2) }\end{array}$ & gi|6522844 & $3 e-79$ & $99 \%$ & VIII.A \\
\hline XF-09E09-gl39 & XF0841 & $\begin{array}{l}\text { Hypothetical } \\
6,1 \mathrm{kDa} \text { protein }\end{array}$ & & & & & VIII.B \\
\hline XF-09E09-gl40 & & $\begin{array}{l}\text { Hypothetical } \\
8,6 \mathrm{kDa} \text { protein }\end{array}$ & & & & & VIII.B \\
\hline XF-09E09-gl4l & & $\begin{array}{l}\text { Hypothetical } \\
\text { 4kDa protein }\end{array}$ & & & & & VIII.B \\
\hline $\mathrm{XF}-09 \mathrm{E} 09-\mathrm{gl} 42$ & XF0840 & $\begin{array}{l}\text { Beta- } \\
\text { galactosidase } \\
\text { (BGA) }\end{array}$ & $\begin{array}{l}\text { Xanthomonas } \\
\text { campestris } p v . \\
\text { manihotis }\end{array}$ & sp|P48982 & 0.0 & $96 \%$ & I.A. 2 \\
\hline XF-09E09-gl43 & XF0839 & $\begin{array}{l}\text { Pyridoxal } \\
\text { phosphate } \\
\text { biosynthetic } \\
\text { protein (PDXA) }\end{array}$ & $\begin{array}{l}\text { Escherichia } \\
\text { coli }\end{array}$ & sp|P19624 & $6 \mathrm{e}-71$ & $98 \%$ & II.D.6 \\
\hline XF-09E09-gl44 & XF0838 & $\begin{array}{l}\text { Peptidyl-prolyl } \\
\text { cis-trans } \\
\text { isomerase (surA) }\end{array}$ & $\begin{array}{l}\text { Escherichia } \\
\text { coli }\end{array}$ & sp|P21202 & $6 e-63$ & $98 \%$ & III.C.I \\
\hline XF-09E09-gl45 & XF0837 & $\begin{array}{ll}\text { Organic solvent } \\
\text { tolerance } \\
\text { precursor }\end{array}$ & $\begin{array}{l}\text { Haemophilus } \\
\text { influenzae }\end{array}$ & sp|P44846 & $3 e-75$ & $93 \%$ & VII.G \\
\hline XF-09E09-gl46 & XF0836 & $\begin{array}{l}\text { Hypothetical } \\
9,8 \mathrm{kDa} \text { protein }\end{array}$ & & & & & VIII.B \\
\hline
\end{tabular}

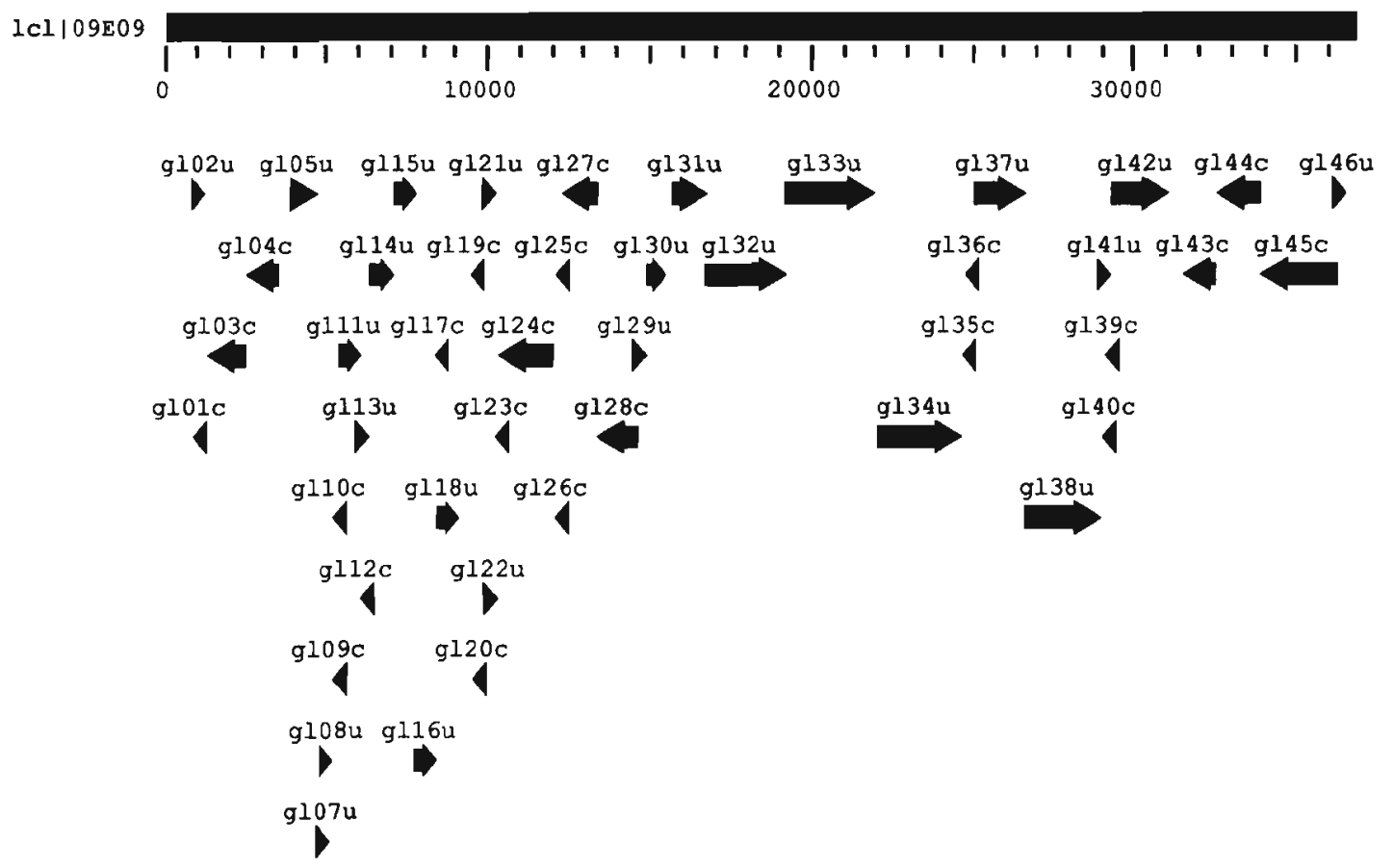

Figura 09. Anotação das ORFs do cosmídeo X0JJ-09E09 preditas pelo programa Glimmer. As ORFs estão denominadas como $\mathrm{gl}{ }^{* *} \mathrm{c}(\mathrm{u})$, onde gl significa a ORF Glimmer seguida do número da ORF no cosmídeo e da letra c (ORF em sentido inverso ao cosmídeo) ou u (ORF com sentido igual à sequência do cosmídeo) 
Na tabela abaixo podemos notar um caso (XF0823) em que todos os hits encontrados pelo BLASTp correspondem à matches parciais. Os primeiros 100 aminoácidos do produto traduzido desta ORF não possui similaridade com nenhuma proteína no banco de dados (NCBI). Esta ORF foi anotada como sendo uma "phosphoglycerate kinase" pois a \% de cobertura da proteína foi de $99 \%$ e seu e-value de e-113. Analizando a composição de aminoácidos, percebemos que este possui uma metionina interna exatamente no local em que se inicia a similaridade com a predita proteína, ou seja, neste caso pode ser que tenha ocorrido uma falsa predição do início desta ORF fazendo com que sua composição real seja de 390 aminoácidos ao contrário do submetido (500 aa) e a observação de match parcial feita seja desnecessária.

Para as demais ORFs podemos notar um baixo valor "E" aliado à uma ampla cobertura da proteína predita, otimizando a anotação feita. Novamente podemos notar algumas ORFs excluídas do banco de dados de Xylella fastidiosa devido ao fato de sobreposição com uma outra ORF maior predita (observar na figura 10 por exemplo a ORF XF0-08A03-g138 completamente sobreposta à ORF XF-08A03-g139).

Tabela 16: ORFs anotadas no cosmídeo X0QV-08A03. As ORFs marcadas em vermelho foram excluídas do banco de dados de ORFs de Xylella fastidiosa.

\begin{tabular}{|c|c|c|c|c|c|c|c|}
\hline \multicolumn{2}{|c|}{ ORFs } & \multirow{2}{*}{$\begin{array}{l}\text { Proteína } \\
\text { 2-octaprenyl-6- } \\
\text { methoxyphenol } \\
\text { hydroxylase }\end{array}$} & \multirow{2}{*}{$\begin{array}{l}\text { Organismo } \\
\text { Eschericha coli }\end{array}$} & \multirow{2}{*}{$\begin{array}{l}\text { Código \# } \\
\text { sp|P25534 }\end{array}$} & \multirow{2}{*}{$\begin{array}{c}\text { E-value } \\
\text { (Blastp) } \\
3 \mathrm{e}-33\end{array}$} & \multirow{2}{*}{$\begin{array}{c}\begin{array}{c}\% \\
\text { cobert. }\end{array} \\
99 \%\end{array}$} & \multirow{2}{*}{$\begin{array}{l}\text { Cat. } \\
\text { II.D.11 }\end{array}$} \\
\hline $\mathrm{XF}-08 \mathrm{~A} 03-\mathrm{gl} 14$ & XF0835 & & & & & & \\
\hline $\mathrm{XF}-08 \mathrm{~A} 03-\mathrm{gl} 15$ & XF0834 & $\begin{array}{l}\text { Conserved } \\
\text { hypothetical } \\
\text { protein (visC) }\end{array}$ & $\begin{array}{l}\text { Escherichia } \\
\text { coli }\end{array}$ & gi|882436 & $8 \mathrm{e}-54$ & $97 \%$ & VIII.A \\
\hline XF-08A03-gl16 & XF0833 & $\begin{array}{l}\text { Transcriptional } \\
\text { regulator } \\
\text { (LysR family) }\end{array}$ & $\begin{array}{l}\text { Pseudomonas } \\
\text { aeruginosa }\end{array}$ & gi|2072311 & $3 e-55$ & $96 \%$ & I.D \\
\hline 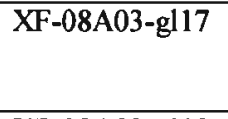 & $\mathrm{XF0832}$ & $\begin{array}{l}\text { Siroheme } \\
\text { synthase } \\
\text { (cysG) }\end{array}$ & $\begin{array}{l}\text { Escherichia } \\
\text { coli }\end{array}$ & sp|P11098 & $3 e-96$ & $98 \%$ & II.D. 12 \\
\hline $\mathrm{XF}-08 \mathrm{~A} 03-\mathrm{gl} 18$ & XF0831 & $\begin{array}{l}\text { Cysteine } \\
\text { synthase } \\
\text { (CysK) }\end{array}$ & $\begin{array}{l}\text { Bacillus } \\
\text { subtilis }\end{array}$ & $\mathrm{sp} \mid \mathrm{P} 37887$ & 1e-78 & $98 \%$ & II.A.3 \\
\hline XF-08A03-gl19 & XF0830 & $\begin{array}{l}\text { Hypothetical } \\
15,1 \mathrm{kDa} \\
\text { protein }\end{array}$ & & & & & VIII.B \\
\hline$\overline{\mathrm{XF}}-08 \mathrm{~A} 03-\mathrm{gl} 20$ & & $\begin{array}{l}\text { Hypothetical } \\
\text { 3,3kDa protein }\end{array}$ & & & & & VIII.B \\
\hline$\overline{\mathrm{XF}-08 \mathrm{~A} 03-\mathrm{gl} 21}$ & & $\begin{array}{l}\text { Hypothetical } \\
10,2 \mathrm{kDa} \\
\text { protein } \\
\end{array}$ & & & & & VIII.B \\
\hline
\end{tabular}




\begin{tabular}{|c|c|c|c|c|c|c|c|}
\hline$\overline{\mathrm{XF}-08 \mathrm{~A} 03-\mathrm{g} \mid 22}$ & XF0829 & $\begin{array}{l}\text { Hypothetical } \\
8,3 \mathrm{kDa} \text { protein }\end{array}$ & & & & & VIII.B \\
\hline $\mathrm{XF}-08 \mathrm{~A} 03-\mathrm{g} \mid 23$ & XF0828 & $\begin{array}{l}\text { Hypothetical } \\
21,9 k D a \\
\text { protein }\end{array}$ & & & & & VIII.B \\
\hline $\begin{array}{l}\mathrm{XF}-08 \mathrm{~A} 03-\mathrm{gl24} \\
\end{array}$ & XF0827 & $\begin{array}{l}\text { Hypothetical } \\
28,1 \mathrm{kDa} \\
\text { protein }\end{array}$ & & & & & VIII.B \\
\hline XF-08A03-gl25 & & $\begin{array}{l}\text { Hypothetical } \\
3,7 \mathrm{k} \text { Da protein }\end{array}$ & & & & & VIII.B \\
\hline XF-08A03-gl26 & & $\begin{array}{l}\text { Hypothetical } \\
3,8 \mathrm{kDa} \text { protein }\end{array}$ & & & & & VIII.B \\
\hline XF-08A03-gl27 & XF0826 & $\begin{array}{l}\text { Fructose- } \\
\text { bisphosphate } \\
\text { aldolase }\end{array}$ & $\begin{array}{l}\text { Arabidopsis } \\
\text { thaliana }\end{array}$ & gi|2982453 & $4 e-95$ & $92 \%$ & $\begin{array}{l}\text { L.C. } 4 \\
\text { L.B. } 3\end{array}$ \\
\hline $\begin{array}{l}\mathrm{XF}-08 \mathrm{~A} 03-\mathrm{gl} 28 \\
\end{array}$ & XF0825 & $\begin{array}{l}\text { Hypothetica } \\
\text { 9kDa protein }\end{array}$ & & & & & VIII.B \\
\hline $\begin{array}{l}\mathrm{XF}-08 \mathrm{~A} 03-\mathrm{gl} 29 \\
\end{array}$ & XF0824 & $\begin{array}{l}\text { Pyruvate } \\
\text { kinase type II } \\
\text { (PYKA) }\end{array}$ & $\begin{array}{l}\text { Escherichia } \\
\text { coli }\end{array}$ & sp|P21599 & e-108 & $100 \%$ & $\begin{array}{ll}\text { I.C. } 4 \\
\end{array}$ \\
\hline $\mathrm{XF}-08 \mathrm{~A} 03-\mathrm{gl} 30$ & & $\begin{array}{l}\text { Hypothetical } \\
11,7 \mathrm{kDa} \\
\text { protein }\end{array}$ & & & & & $\begin{array}{l}\text { VIII.B } \\
\end{array}$ \\
\hline XF-08A03-g131 & XF0823 & $\begin{array}{l}\text { Phosphoglycer } \\
\text { ate kinase } \\
\text { (PGK) }\end{array}$ & $\begin{array}{l}\text { Escherichia } \\
\text { coli }\end{array}$ & sp|P11665 & $e-113$ & $99 \%$ & $\begin{array}{l}\text { I.C. } 4 \\
\text { I.B. } 3\end{array}$ \\
\hline $\mathrm{XF}-08 \mathrm{~A} 03$-gl32 & & $\begin{array}{l}\text { Hypothetical } \\
6,9 \mathrm{kDa} \text { protein }\end{array}$ & & & & & VIII.B \\
\hline XF-08A03-gl33 & & $\begin{array}{l}\text { Hypothetical } \\
5,0 \mathrm{kDa} \text { protein }\end{array}$ & & & & & VIII.B \\
\hline XF-08A03-gl34 & $\overline{\mathrm{XF} 0822}$ & $\begin{array}{l}\text { Glutamyl- } \\
\text { tRNA } \\
\text { synthetase } \\
\text { (GLTX) }\end{array}$ & $\begin{array}{l}\text { Escherichia } \\
\text { coli }\end{array}$ & sp|P04805 & e-141 & $98 \%$ & $\begin{array}{l}\text { II.B.4 } \\
\text { II.D. } 12\end{array}$ \\
\hline XF-08A03-g135 & XF0821 & $\begin{array}{l}\text { transcriptional } \\
\text { regulator (Fur } \\
\text { family) (ZUR) }\end{array}$ & $\begin{array}{l}\text { Escherichia } \\
\text { coli }\end{array}$ & $\mathrm{sp} \mid \mathbf{P} 32692$ & $2 e-24$ & $81 \%$ & I.D \\
\hline XF-08A03-g136 & XF0820 & $\begin{array}{l}\text { Hypothetical } \\
57,7 \mathrm{kDa} \\
\text { protein }\end{array}$ & & & & & VIII.B \\
\hline XF-08A03-g137 & & $\begin{array}{l}\text { Hypothetical } \\
4,5 \mathrm{kDa} \text { protein }\end{array}$ & & & & & VIII.B \\
\hline XF-08A03-gl38 & & $\begin{array}{l}\text { Hypothetical } \\
15,8 \mathrm{kDa} \\
\text { protein }\end{array}$ & & & & & VIII.B \\
\hline XF-08A03-gl39 & XF0818 & $\begin{array}{l}\text { Endo-1,4-beta- } \\
\text { glucanase } \\
\text { (engXCA) }\end{array}$ & $\begin{array}{l}\text { Xanthomonas } \\
\text { campestris pv. } \\
\text { campestris }\end{array}$ & sp|P19487 & e-144 & $75 \%$ & VII.D \\
\hline XF-08A03-gl40 & XF0817 & $\begin{array}{l}\text { Hypothetical } \\
6,3 \mathrm{kDa} \text { protein }\end{array}$ & & & & & VIIILB \\
\hline
\end{tabular}




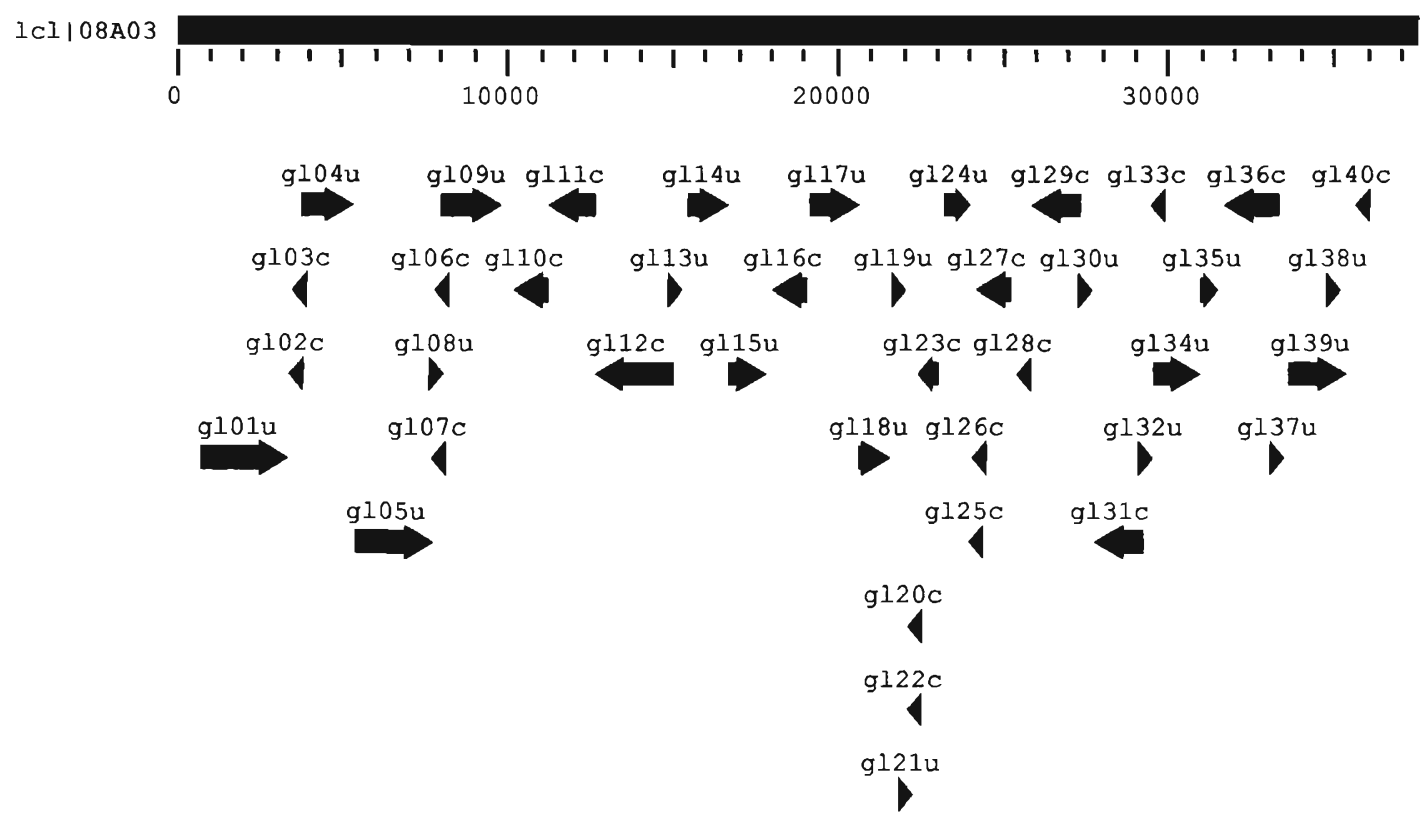

Figura 10: Anotação das ORFs do cosmídeo X0QV-08A03 preditas pelo programa Glimmer. As ORFs estão denominadas como $\mathrm{gl}^{* *} \mathrm{c}(\mathrm{u})$, onde gl significa a ORF Glimmer seguida do número da ORF no cosmídeo e da letra c (ORF em sentido inverso ao cosmídeo) ou u (ORF com sentido igual à seqüência do cosmídeo). 
A segunda e a terceira ORF estão presentes no banco de Xylella fastidiosa mas devido à mudanças de nomenclatura não se pode verificar qual o nome antigo (indicando qual ORF do cosmídeo X0QR-07H04) que se relacionava aos presentes no banco de dados (XF0815 e XF0816).

Como dito até o momento, a decisão pela predição da função de determinada ORF se baseia em observações manuais, considerando os parâmetros de e-value e de $\%$ de cobertura. No caso da ORF XF0791 podemos verificar um e-value na faixa de valores duvidosos fazendo com que a certeza de uma anotação correta desapareça. No entanto, e neste caso em específico, comparando o padrão de distribuição de ORFs em genoma completo de Escherichia coli, podemos perceber um operon caracterizado nesta região eglobando a ORF XF0791 (veja figura abaixo). Da região marcada em vermelho (gene yabB) até o gene secA em E.coli podemos verificar os mesmos representantes na mesma disposição no gene de Xylella fastidiosa, o que nos auxilia a anotar tal ORF como sendo uma "cell division protein (FTSL)".

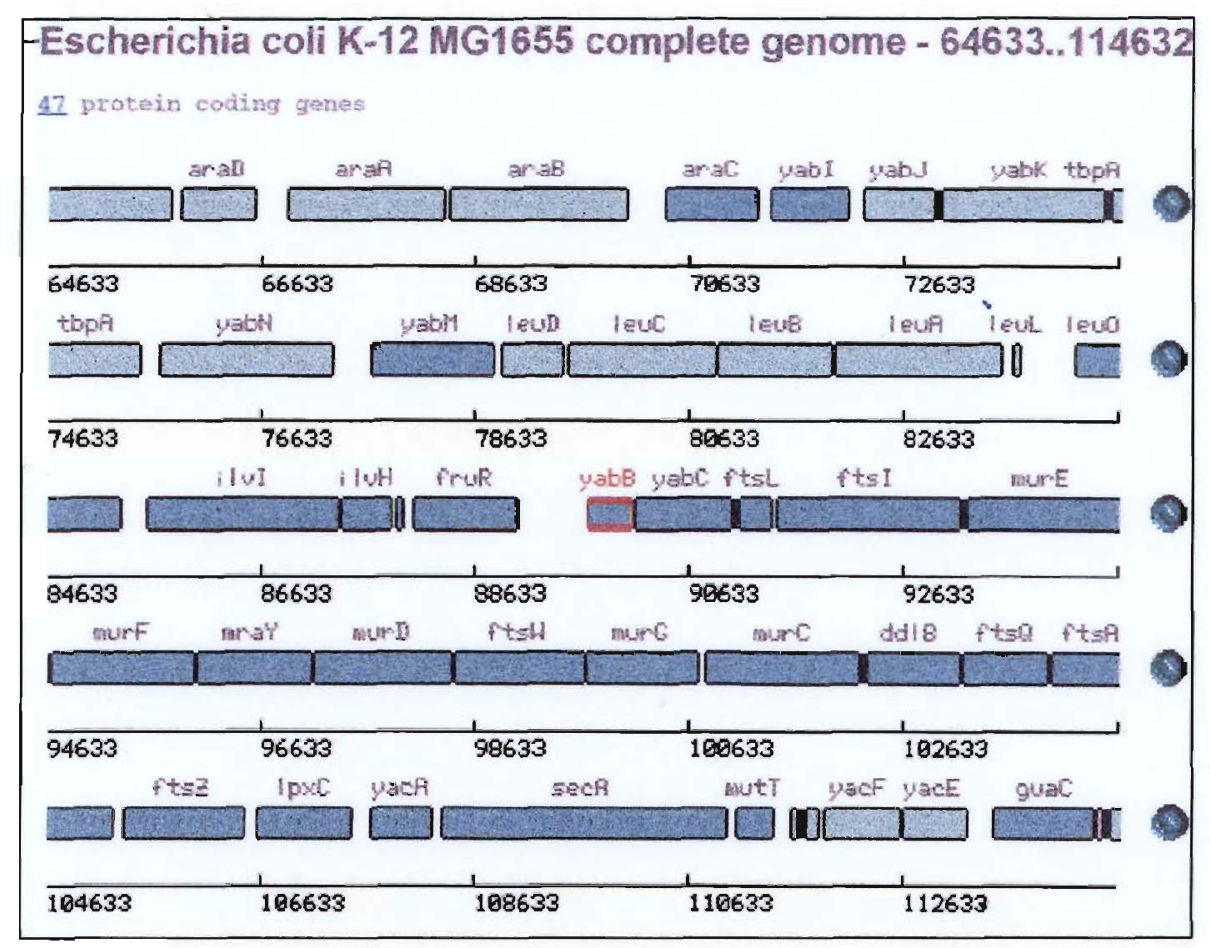

Figura 11: Disposição de genes encontrados em genoma completo de Escherichia coli K-12. 
Tabela 17: ORFs anotadas no cosmídeo $\mathrm{X} 0 \mathrm{QR}-07 \mathrm{H} 04$.

\begin{tabular}{|c|c|c|c|c|c|c|c|}
\hline \multicolumn{2}{|l|}{ ORFs } & \multirow{2}{*}{$\begin{array}{l}\text { Proteína } \\
\text { zinc protease } \\
\text { (SC9B10.04) }\end{array}$} & \multirow{2}{*}{$\begin{array}{l}\text { Organismo } \\
\begin{array}{l}\text { Streptomyces } \\
\text { coelicolor }\end{array}\end{array}$} & \multirow{2}{*}{$\begin{array}{l}\text { Código \# } \\
\text { gi|2661690 }\end{array}$} & \multirow{2}{*}{$\begin{array}{c}\begin{array}{c}\text { E-value } \\
\text { (Blastp) }\end{array} \\
3 e-72 \\
\end{array}$} & \multirow{2}{*}{$\begin{array}{c}\begin{array}{c}\% \\
\text { cobert. }\end{array} \\
87 \%\end{array}$} & \multirow{2}{*}{$\begin{array}{l}\text { Cat. } \\
\text { III.C.3 }\end{array}$} \\
\hline XF-07H040-gl06 & XF0816 & & & & & & \\
\hline XF-07H04-gl? & XF0815 & $\begin{array}{l}\text { Hypothetical } \\
5,8 \mathrm{kDa} \text { protein }\end{array}$ & & & & & VIII.B \\
\hline XF-07H04-gl? & XF0814 & $\begin{array}{l}\text { Hypothetical } \\
6,0 \mathrm{kDa} \text { protein }\end{array}$ & & & & & VIII.B \\
\hline $\mathrm{XF}-07 \mathrm{H} 040$-gl11 & XF0813 & $\begin{array}{l}\text { Hypothetical } \\
22,6 \mathrm{kDa} \\
\text { protein }\end{array}$ & & & & & VIII.B \\
\hline XF-07H040-gl12 & XF0812 & $\begin{array}{l}\text { Hypothetical } \\
5 \mathrm{kDa} \text { protein }\end{array}$ & & & & & VIII.B \\
\hline XF-07H040-gl13 & XF 811 & $\begin{array}{l}\text { Conserved } \\
\text { hypothetical } \\
\text { protein } \\
\text { (PH1028) }\end{array}$ & $\begin{array}{l}\text { Pyrococcus } \\
\text { horikoshii }\end{array}$ & $\begin{array}{c}\mathrm{dbj|BAA301} \\
25\end{array}$ & $5 e-32$ & $85 \%$ & VIILA \\
\hline XF-07H040-gl14 & XF0810 & $\begin{array}{l}\text { Extracellular } \\
\text { endoglucanase } \\
\text { precursor } \\
\text { (ENGXCA) }\end{array}$ & $\begin{array}{l}\text { Xanthomonas } \\
\text { campestris pv. } \\
\text { campestris }\end{array}$ & sp|P19487 & $7 \mathrm{e}-50$ & $76 \%$ & VII.D \\
\hline XF-07H040-gl15 & XF0808 & $\begin{array}{l}\text { Hypothetical } \\
5 \mathrm{kDa} \text { protein }\end{array}$ & & & & & VIII.B \\
\hline XF-07H040-gl16 & XF0807 & $\begin{array}{l}\text { Hypothetical } \\
6,2 \mathrm{kDa} \text { protein }\end{array}$ & & & & & VIII.B \\
\hline XF-07H040-gl17 & XF0806 & $\begin{array}{l}\text { Preprotein } \\
\text { translocase } \\
\text { SecA subunit }\end{array}$ & $\begin{array}{l}\text { Escherichia } \\
\text { coli }\end{array}$ & sp|P10408 & 0.0 & $100 \%$ & V.A.6 \\
\hline XF-07H040-gl18 & XF0805 & $\begin{array}{l}\text { Conserved } \\
\text { hypothetical } \\
\text { protein }\end{array}$ & $\begin{array}{l}\text { Pseudomonas } \\
\text { aeruginosa }\end{array}$ & gi|6715619 & $5 e-58$ & $92 \%$ & VIII.A \\
\hline XF-07H040-gl19 & XF0803 & $\begin{array}{l}\text { UDP-3-O-[3- } \\
\text { hydroxymyrist } \\
\text { oyl] N- } \\
\text { acetylglucosam } \\
\text { ine deacetylase } \\
\text { (lpxC) }\end{array}$ & $\begin{array}{l}\text { Pseudomonas } \\
\text { aeruginosa }\end{array}$ & gi|1890655 & e-103 & $99 \%$ & IV.C \\
\hline XF-07H040-gl20 & XF0802 & $\begin{array}{l}\text { Cell division } \\
\text { protein (FTSZ) }\end{array}$ & $\begin{array}{l}\text { Pseudomonas } \\
\text { putita }\end{array}$ & sp|Q59692 & e-111 & $100 \%$ & V.B \\
\hline $\mathrm{XF}-07 \mathrm{H} 040-\mathrm{g} \mid 21$ & XF0801 & $\begin{array}{l}\text { Cell division } \\
\text { protein (FTSA } \\
\text { ou DIVA) }\end{array}$ & $\begin{array}{l}\text { Escherichia } \\
\text { coli }\end{array}$ & $\mathrm{sp} / \mathrm{P06137}$ & e-106 & $100 \%$ & $\begin{array}{l}\text { V.B } \\
\text { IV.A }\end{array}$ \\
\hline $\mathrm{XF}-07 \mathrm{H} 040$-gl22 & $\mathrm{XF0800}$ & $\begin{array}{l}\text { Cell division } \\
\text { protein (FTSQ) }\end{array}$ & $\begin{array}{l}\text { Escherichia } \\
\text { coli }\end{array}$ & $\mathrm{sp} \mid \mathrm{P} 06136$ & $1 \mathrm{e}-24$ & $81 \%$ & $\begin{array}{l}\text { V.B } \\
\text { IV.A.1 }\end{array}$ \\
\hline XF-07H040-gl23 & XF0799 & $\begin{array}{l}\text { D-alanine--D- } \\
\text { alanine ligase } \\
\text { B (DDLB ou } \\
\text { DDL) }\end{array}$ & $\begin{array}{l}\text { Escherichia } \\
\text { coli }\end{array}$ & sp|P07862 & $3 e-78$ & $97 \%$ & IV.B \\
\hline XF-07H040-gl24 & XF0798 & $\begin{array}{l}\text { UDP-N- } \\
\text { acetylmuramat } \\
\text { e--alanine } \\
\text { ligase (MURC) }\end{array}$ & $\begin{array}{l}\text { Escherichia } \\
\text { coli }\end{array}$ & sp|P17952 & e-118 & $94 \%$ & IV.B \\
\hline XF-07H040-gl25 & XF0797 & $\begin{array}{l}\text { UDP-N- } \\
\text { acetylglucosam } \\
\text { ine--N- } \\
\text { acetylmuramyl } \\
\text {-(pentapeptide) }\end{array}$ & $\begin{array}{l}\text { Escherichia } \\
\text { coli }\end{array}$ & $\mathrm{sp} \mid \mathrm{P} 17443$ & $1 e-61$ & $95 \%$ & IV.B \\
\hline
\end{tabular}




\begin{tabular}{|c|c|c|c|c|c|c|c|}
\hline & & $\begin{array}{l}\text { pyrophosphory } \\
\text { l-undecapreno } \\
\text { (MURG) }\end{array}$ & & & & & \\
\hline XF-07H040-g126 & XF0796 & $\begin{array}{l}\text { cell division } \\
\text { protein } \\
\text { (FTSW) }\end{array}$ & $\begin{array}{l}\text { Escherichia } \\
\text { coli }\end{array}$ & sp|P16457 & $1 e-57$ & $86 \%$ & V.B \\
\hline XF-07H040-gl27 & XF0795 & $\begin{array}{l}\text { phospho-N- } \\
\text { acetylmuramoy } \\
\text { 1-pentapeptide- } \\
\text { transferase } \\
\text { (MRAY OR } \\
\text { MURX) }\end{array}$ & $\begin{array}{l}\text { Escherichia } \\
\text { coli }\end{array}$ & sp|P15876 & e-144 & $100 \%$ & IV.B \\
\hline $\begin{array}{l}\mathrm{XF}-07 \mathrm{H} 040-\mathrm{gl} 28 \\
\end{array}$ & XF0794 & $\begin{array}{l}\text { UDP-N- } \\
\text { acetylmuramoy } \\
\text { lalanyl-D- } \\
\text { glutamyl-2,6- } \\
\text { diaminopimelat } \\
\text { e--D-alanyl-D- } \\
\text { alanyl ligase } \\
\text { (MURF OR } \\
\text { MRA) }\end{array}$ & $\begin{array}{l}\text { Escherichia } \\
\text { coli }\end{array}$ & sp|P11880 & $3 e-80$ & $99 \%$ & IV.B \\
\hline XF-07H040-g129 & XF0793 & $\begin{array}{l}\text { UDP-N- } \\
\text { acetylmuramoy } \\
\text { lalanyl-D- } \\
\text { glutamate--2,6- } \\
\text { diaminopimelat } \\
\text { e ligase (murE) }\end{array}$ & $\begin{array}{l}\text { Escherichia } \\
\text { coli }\end{array}$ & gi|2177098 & $2 e-88$ & $98 \%$ & IV.B \\
\hline XF-07H040-gl30 & XF0792 & $\begin{array}{l}\text { Penicillin- } \\
\text { binding protein } \\
3 \text { (FTSI OR } \\
\text { PBPB) }\end{array}$ & $\begin{array}{l}\text { Escherichia } \\
\text { coli }\end{array}$ & sp|P04286 & e-148 & $96 \%$ & IV.B \\
\hline XF-07H040-gl31 & XF0791 & $\begin{array}{l}\text { Cell division } \\
\text { protein (FTSL } \\
\text { OR HI1131) }\end{array}$ & $\begin{array}{l}\text { Haemophilus } \\
\text { influenzae Rd }\end{array}$ & sp|P45058 & $5 e-05$ & $79 \%$ & V.B \\
\hline XF-07H040-gl32 & XF0790 & $\begin{array}{l}\text { Conserved } \\
\text { hypothetical } \\
\text { protein } \\
\text { (YABC) }\end{array}$ & $\begin{array}{l}\text { Escherichia } \\
\text { coli }\end{array}$ & sp|P18595 & $2 \mathrm{e}-60$ & $97 \%$ & $\begin{array}{l}\text { VIII.A } \\
\end{array}$ \\
\hline XF-07H040-gl33 & XF0789 & $\begin{array}{l}\text { Conserved } \\
\text { hypothetical } \\
\text { protein } \\
\text { (HII1129) }\end{array}$ & $\begin{array}{l}\text { Haemophilus } \\
\text { influenzae }\end{array}$ & sp|P45056 & $3 e-16$ & $100 \%$ & $\begin{array}{l}\text { VIII.A } \\
\end{array}$ \\
\hline XF-07H040-gl34 & XF0788 & $\begin{array}{l}\text { Hypothetical } \\
5,7 \mathrm{kDa} \text { protein }\end{array}$ & & & & & VIII.B \\
\hline XF-07H040-gl35 & XF0787 & $\begin{array}{l}\text { Hypothetical } \\
7,6 \mathrm{kDa} \text { protein }\end{array}$ & & & & & VIII.B \\
\hline XF-07H040-g136 & XF0786 & $\begin{array}{l}\text { Hypothetical } \\
6,3 \mathrm{kDa} \text { protein }\end{array}$ & & & & & $\begin{array}{l}\text { VIII.B } \\
\end{array}$ \\
\hline XF-07H040-gl39 & XF0785 & $\begin{array}{l}\text { Sulfur } \\
\text { deprivation } \\
\text { response } \\
\text { regulator } \\
\text { (SAC1) }\end{array}$ & $\begin{array}{l}\text { Synechocystis } \\
s p\end{array}$ & gi|2499531 & $3 e-58$ & $97 \%$ & $\begin{array}{l}\text { VII.G } \\
\text { V.A.2 }\end{array}$ \\
\hline XF-07H040-gl40 & XF0784 & $\begin{array}{l}\text { Conserved } \\
\text { hypothetical } \\
\text { protein } \\
\text { (YGGH) } \\
\end{array}$ & $\begin{array}{l}\text { Escherichia } \\
\text { coli }\end{array}$ & sp|P32049 & $7 e-59$ & $92 \%$ & VIII.A \\
\hline XF-07H040-gl42 & XF0804 & $\begin{array}{l}\text { Hypothetical } \\
9,9 \mathrm{kDa} \text { protein }\end{array}$ & & & & & VIII.B \\
\hline
\end{tabular}


$1 \mathrm{cl} 107 \mathrm{HO}$
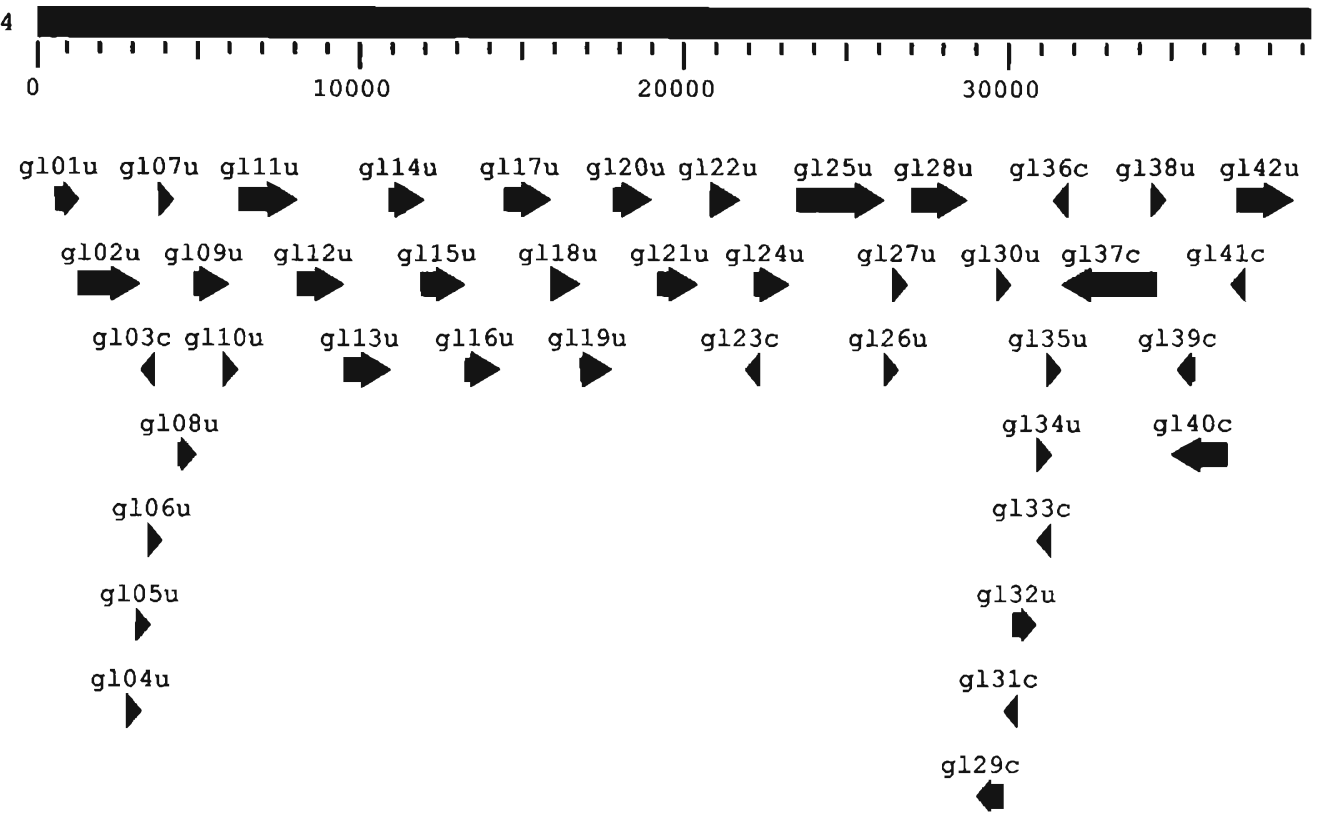

Figura 12: Anotação das ORFs do cosmídeo X0QR-07H04 preditas pelo programa Glimmer. As ORFs estão denominadas como $\mathrm{gl}^{* *} \mathrm{c}(\mathrm{u})$, onde $\mathrm{gl}$ significa a ORF Glimmer seguida do número da ORF no cosmídeo e da letra c (ORF em sentido inverso ao cosmídeo) ou u (ORF com sentido igual à seqüência do cosmídeo). 
Tabela 18: ORFs anotadas no cosmídeo X0QV-03D03. As ORFs marcadas em vermelho foram excluídas do banco de dados de ORFs de Xylella fastidiosa.

\begin{tabular}{|c|c|c|c|c|c|c|c|}
\hline \multicolumn{2}{|c|}{ ORFs } & \multirow{2}{*}{$\begin{array}{l}\text { Proteina } \\
\text { Thiamine } \\
\text { biosynthesis } \\
\text { protein (thiG) }\end{array}$} & \multirow{2}{*}{$\begin{array}{l}\text { Organismo } \\
\text { Aquifex } \\
\text { aeolicul }\end{array}$} & \multirow{2}{*}{$\begin{array}{l}\text { Código \# } \\
\text { gi|2984360 }\end{array}$} & \multirow{2}{*}{$\begin{array}{c}\text { E-value } \\
\text { (Blastp) } \\
2 \mathrm{e}-77\end{array}$} & \multirow{2}{*}{$\begin{array}{c}\% \\
\text { cobert. } \\
95 \%\end{array}$} & \multirow{2}{*}{$\begin{array}{l}\text { Cat. } \\
\text { II.D.8 }\end{array}$} \\
\hline $\mathrm{XF}-03 \mathrm{D} 03-\mathrm{gl} 16$ & Xf0783 & & & & & & \\
\hline $\mathrm{XF}-03 \mathrm{D} 03$-gl17 & XF0782 & $\begin{array}{l}\text { Conserved } \\
\text { hypothetical } \\
\text { protein }\end{array}$ & $\begin{array}{l}\text { Synechocystis } \\
\text { sp. }\end{array}$ & gi|1673304 & le-05 & $94 \%$ & $\overline{\text { VIII.A }}$ \\
\hline$\overline{X F}-03 \mathrm{D} 03-\mathrm{gl} 18$ & & $\begin{array}{l}\text { Hypothetical } \\
4,6 \mathrm{kDa} \text { protein }\end{array}$ & & & & & VIII.B \\
\hline XF-03D03-gl19 & XF0781 & $\begin{array}{l}\text { Lipase/esterase } \\
\text { (estA) }\end{array}$ & $\begin{array}{l}\text { Pseudomonas } \\
\text { aeruginosa }\end{array}$ & gi|2218156 & $2 \mathrm{e}-34$ & $93 \%$ & I.A.2 \\
\hline $\mathrm{XF}-03 \mathrm{D} 03-\mathrm{gl} 20$ & XF0780 & $\begin{array}{l}\text { Hypothetical } \\
9,1 \mathrm{kDa} \text { protein }\end{array}$ & & & & & VIII.B \\
\hline $\mathrm{XF}-03 \mathrm{D} 03-\mathrm{gl} 21$ & XF0778 & $\begin{array}{l}\text { O-antigen } \\
\text { acetylase } \\
\text { (oafA) }\end{array}$ & $\begin{array}{l}\text { Salmonella } \\
\text { typhimurium }\end{array}$ & gi|1518853 & le-55 & $99 \%$ & IV.C \\
\hline $\mathrm{XF}-03 \mathrm{D} 03-\mathrm{gl} 22$ & & $\begin{array}{l}\text { Hypothetical } \\
\text { 4,9kDa protein }\end{array}$ & & & & & VIII.B \\
\hline $\mathrm{XF}-03 \mathrm{D} 03-\mathrm{gl} 23$ & & $\begin{array}{l}\text { Hypothetical } \\
\text { 26kDa protein }\end{array}$ & & & & & VIII.B \\
\hline $\mathrm{XF}-03 \mathrm{D} 03-\mathrm{g} \mid 24$ & XF0777 & $\begin{array}{l}\text { Membrane } \\
\text { protein } \\
\text { (ACTI-3) }\end{array}$ & $\begin{array}{l}\text { Streptomyces } \\
\text { coelicolor }\end{array}$ & sp|Q53902 & $5 \mathrm{e}-11$ & $72 \%$ & IV.A.1 \\
\hline $\mathrm{XF}-03 \mathrm{D} 03-\mathrm{g} \mid 25$ & XF0775 & $\begin{array}{l}\text { Hypothetical } \\
38,7 \mathrm{kDa} \\
\text { protein }\end{array}$ & & & & & VIII.B \\
\hline $\mathrm{XF}-03 \mathrm{D} 03-\mathrm{gl} 26$ & Xf0774 & $\begin{array}{l}\text { Hypothetical } \\
10,7 \mathrm{kDa} \\
\text { protein }\end{array}$ & & & & & VIII.B \\
\hline $\mathrm{XF}-03 \mathrm{D} 03-\mathrm{gl} 27$ & Xf0773 & $\begin{array}{l}\text { Hypothetical } \\
3,9 \mathrm{kDa} \text { protein }\end{array}$ & & & & & VIII.B \\
\hline XF-03D03-gl28 & & $\begin{array}{l}\text { Hypothetical } \\
6,9 \mathrm{kDa} \text { protein }\end{array}$ & & & & & VIII.B \\
\hline XF-03D03-gl29 & & $\begin{array}{l}\text { Hypothetical } \\
8,4 \mathrm{kDa} \text { protein }\end{array}$ & & & & & VIII.B \\
\hline $\mathrm{XF}-03 \mathrm{D} 03-\mathrm{g} \mid 30$ & XF0772 & $\begin{array}{l}\text { Hypothetical } \\
30,4 \mathrm{kDa} \\
\text { protein }\end{array}$ & & & & & VIII.B \\
\hline XF-03D03-gl31 & XF0771 & $\begin{array}{l}\text { acyl carrier } \\
\text { protein }(\mathrm{acpC})\end{array}$ & $\begin{array}{l}\text { Streptococcus } \\
\text { agalactiae }\end{array}$ & gi|4886773 & $2 \mathrm{e}-06$ & $69 \%$ & II.E \\
\hline $\mathrm{XF}-03 \mathrm{D} 03-\mathrm{gl} 32$ & XF0769 & $\begin{array}{l}\text { Pteridine- } \\
\text { dependent } \\
\text { deoxygenase } \\
\text { (rapK) }\end{array}$ & $\begin{array}{l}\text { Streptomyces } \\
\text { hygroscopicus }\end{array}$ & gi|987108 & $1 e-30$ & $80 \%$ & VII.C \\
\hline $\mathrm{XF}-03 \mathrm{D} 03$-gl33 & & $\begin{array}{l}\text { Hypothetical } \\
6,4 \mathrm{kDa} \text { protein }\end{array}$ & & & & & VIII.B \\
\hline $\mathrm{XF}-03 \mathrm{D} 03-\mathrm{gl} 34$ & XF0768 & $\begin{array}{l}\text { Conserved } \\
\text { hypothetical } \\
\text { protein }\end{array}$ & $\begin{array}{l}\text { Synechocystis } \\
\text { sp }\end{array}$ & $\begin{array}{c}\mathrm{dbj} \mid \mathrm{BAA} 178 \\
53\end{array}$ & $3 \mathrm{e}-23$ & $95 \%$ & VIII.A \\
\hline XF-03D03-gl35 & XF0767 & $\begin{array}{l}\text { transcriptional } \\
\text { regulator } \\
\text { (ArsR family) } \\
\text { (HLYU) }\end{array}$ & $\begin{array}{l}\text { Vibrio } \\
\text { cholerae }\end{array}$ & sp|P52695 & le-13 & $89 \%$ & $\begin{array}{l}\text { I.D } \\
\text { III.B }\end{array}$ \\
\hline
\end{tabular}




\begin{tabular}{|c|c|c|c|c|c|c|c|}
\hline XF-03D03-gl36 & XF0766 & $\begin{array}{l}\text { Conserved } \\
\text { hypothetical } \\
\text { protein }\end{array}$ & $\begin{array}{l}\text { Halobacterium } \\
\text { sp }\end{array}$ & gi|2822322 & $1 e-06$ & $80 \%$ & VIII.A \\
\hline XF-03D03-gl37 & XF0765 & $\begin{array}{l}\text { Conserved } \\
\text { hypothetical } \\
\text { protein }\end{array}$ & $\begin{array}{l}\text { Halobacterium } \\
\text { sp }\end{array}$ & $\begin{array}{c}\text { gb|AAC828 } \\
30.1\end{array}$ & $6 \mathrm{e}-09$ & $78 \%$ & VIII.A \\
\hline XF-03D03-gl38 & XF0764 & $\begin{array}{l}\text { Membrane } \\
\text { protein } \\
\text { (SCF56.03) }\end{array}$ & $\begin{array}{l}\text { Streptomyces } \\
\text { coelicolor }\end{array}$ & gi|6562818 & $5 e-32$ & $96 \%$ & IV.A.1 \\
\hline XF-03D03-gl39 & XF0763 & $\begin{array}{l}\text { Hypothetical } \\
11,3 \mathrm{kDa} \\
\text { protein }\end{array}$ & & & & & VIII.B \\
\hline XF-03D03-gl40 & & $\begin{array}{l}\text { Hypothetical } \\
11,8 \mathrm{kDa} \\
\text { protein }\end{array}$ & & & & & VIII.B \\
\hline XF-03D03-gl41 & XF0762 & $\begin{array}{l}\text { Deoxycytidine } \\
\text { triphosphate } \\
\text { deaminase } \\
\text { (dcd) }\end{array}$ & $\begin{array}{l}\text { Chlamydia } \\
\text { pneumoniae }\end{array}$ & gi|4376670 & $2 \mathrm{e}-72$ & $99 \%$ & II.B.3 \\
\hline XF-03D03-g142 & & $\begin{array}{l}\text { Hypothetical } \\
4,4 \mathrm{kDa} \text { protein }\end{array}$ & & & & & VIII.B \\
\hline XF-03D03-gl43 & XF0761 & $\begin{array}{l}\text { Conserved } \\
\text { hypothetical } \\
\text { protein } \\
\text { (SCI11.36c) }\end{array}$ & $\begin{array}{l}\text { Deinococcus } \\
\text { radiodurans }\end{array}$ & gi|5531457 & $1 e-26$ & $88 \%$ & VIII.A \\
\hline $\mathrm{XF}-03 \mathrm{D} 03-\mathrm{gl} / 44$ & $\overline{\text { XF0760 }}$ & $\begin{array}{l}\text { DNA } \\
\text { mismatch } \\
\text { repair protein } \\
\text { MutL }\end{array}$ & $\begin{array}{l}\text { Salmonella } \\
\text { typhimurium }\end{array}$ & sp|P14161 & le-97 & $89 \%$ & III.A.4 \\
\hline XF-03D03-gl45 & & $\begin{array}{l}\text { Hypothetical } \\
5 \mathrm{kDa} \text { protein }\end{array}$ & & & & & VIII.B \\
\hline XF-03D03-g|46 & XF0759 & $\begin{array}{l}\mathrm{N}- \\
\text { acetylmuramoy } \\
\text { l-L-alanine } \\
\text { amidase } \\
\text { precursor } \\
\text { (AMIC) } \\
\end{array}$ & $\begin{array}{l}\text { Escherichia } \\
\text { coli }\end{array}$ & sp|Q46929 & $4 \mathrm{e}-50$ & $53 \%$ & IV.B \\
\hline XF-03D03-gl47 & XF0758 & $\begin{array}{l}\text { Conserved } \\
\text { hypothetical } \\
\text { protein (YJEE) }\end{array}$ & $\begin{array}{l}\text { Escherichia } \\
\text { coli }\end{array}$ & $\mathrm{sp} \mid \mathrm{P} 31805$ & $2 e-24$ & $93 \%$ & VIII.A \\
\hline
\end{tabular}




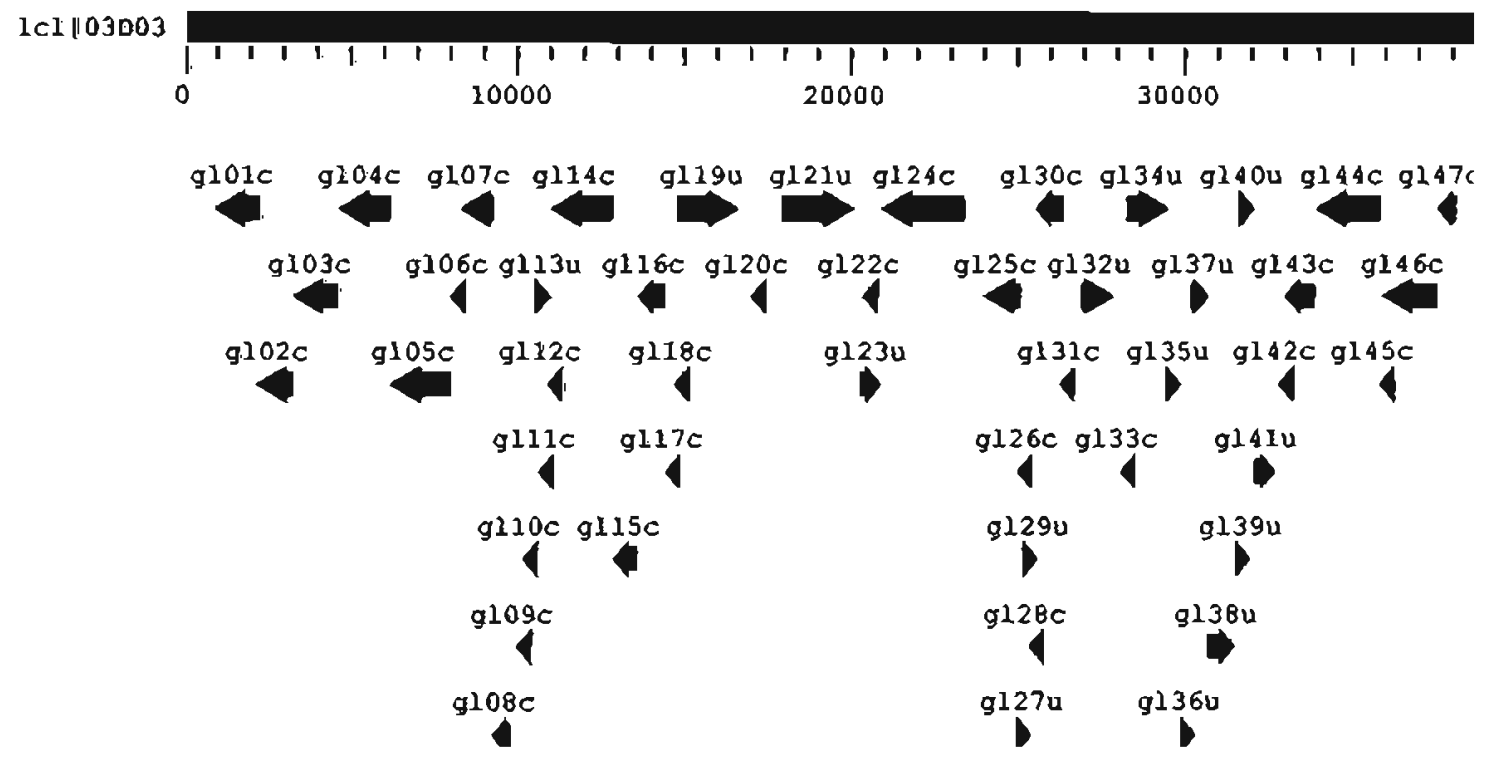

Figura 13: Anotaçă das ORFs do cosmídeo X0QV-03D03 preditas pelo programa Glimmer. As ORFs estão denominadas como gl** $c(u)$, onde gl significa a ORF Glimmer seguida do número da ORF no cosmídeo e da letra c (ORF em sentido inverso ao cosmídeo) ou u (ORF com sentido igual à seqưência do cosmídeo). 
Na tabela abaixo podemos notar outro exemplo de uma anotação que deve ser revista. A ORF denominada de XF0754 anotada como uma "virulence protein" possui apenas $45 \%$ de cobertura de tal proteína, quando o segundo melhor hit (1e-37) poderia melhor caracterizar tal ORF ( $80 \%$ de cobertura). A ORF seria então anotada como uma "hypothetical protein (virA 3' region)" de categoria VIII.A (conserved hypothetical protein) com uma observação do porquê da escolha.

No caso da ORF XF0743 a anotação inserida no banco de dados de Xylella fastidiosa está como se esta ORF representasse uma "Integration host factor alpha subunit (himA)" com um e-value de 6e-36. No entanto, o melhor alinhamento (le-45) foi observado com uma "GumA protein", apresentando também uma total cobertura da proteína. Este caso pode representar uma escolha não pelo score do alinhamento mas como pela comparação com o genoma de Escherichia coli. Notamos pela figura abaixo (retirada do genoma completo de Escherichia coli $\mathrm{K}-12$ ) o padrão de distribuição de ORFs, constando o gene himA (ORF XF0743, marcado em vermelho) e seqüencialmente os genes pheT (XF0742), pheS (XF0741), rplT (XF0740), rpmI (XF0739), infC (XF0737) e thrS (XF0736), explicando o porquê da escolha da proteína "integration host factor alpha subunit".

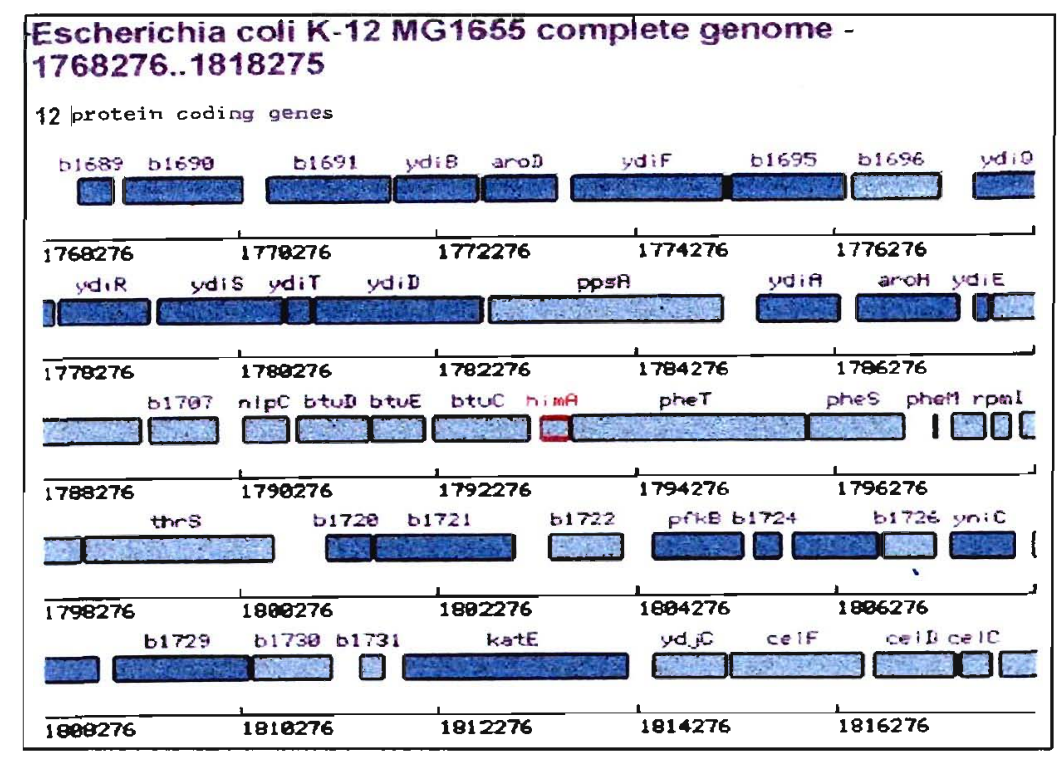

Figura 14: Alinhamento de ORFs em genoma completo de Escherichia coli. O retângulo circundando em vermelho representa o gene para uma "Integration host factor alpha subunit (himA)". 
Tabela 19: ORFs anotadas no cosmídeo X0QV-07B03. As ORFs marcadas em vermelho foram excluídas do banco de dados de ORFs de Xylella fastidiosa.

\begin{tabular}{|c|c|c|c|c|c|c|c|}
\hline \multicolumn{2}{|l|}{ ORFs } & \multirow{2}{*}{$\begin{array}{l}\text { Proteína } \\
\begin{array}{l}\text { Conserved } \\
\text { hypothetical } \\
\text { protein (YJEF) }\end{array}\end{array}$} & \multirow{2}{*}{$\begin{array}{l}\text { Organismo } \\
\text { Escherichia } \\
\text { coli }\end{array}$} & \multirow{2}{*}{$\begin{array}{l}\text { Código \# } \\
\text { sp|P31806 }\end{array}$} & \multirow{2}{*}{$\begin{array}{c}\text { E-value } \\
\text { (Blastp) } \\
4 \mathrm{e}-73\end{array}$} & \multirow{2}{*}{$\begin{array}{c}\% \\
\text { cobert. }\end{array}$} & \multirow{2}{*}{$\begin{array}{l}\text { Cat. } \\
\text { VIII.A }\end{array}$} \\
\hline XF-07B03-gl16 & XF0757 & & & & & & \\
\hline $\mathrm{XF}-07 \mathrm{~B} 03$-gl17 & & $\begin{array}{l}\text { Hypothetical } \\
4,7 \mathrm{kDa} \text { protein }\end{array}$ & & & & & $\overline{\text { VIII.B }}$ \\
\hline $\mathrm{XF}-07 \mathrm{~B} 03-\mathrm{g} \mid 18$ & XF0755 & $\begin{array}{l}\text { Exodeoxyribonu } \\
\text { clease VII large } \\
\text { subunit (XSEA) }\end{array}$ & $\begin{array}{l}\text { Escherichia } \\
\text { coli }\end{array}$ & $\mathrm{sp} \mid \mathrm{P} 04994$ & $8 e-85$ & $95 \%$ & III.A.4 \\
\hline XF-07B03-gl19 & & $\begin{array}{l}\text { Hypothetical } \\
6,4 \mathrm{kDa} \text { protein }\end{array}$ & & & & & VIII.B \\
\hline $\mathrm{XF}-07 \mathrm{~B} 03-\mathrm{g} 120$ & XF0754 & $\begin{array}{l}\text { Virulence } \\
\text { protein (acvB) }\end{array}$ & $\begin{array}{l}\text { Agrobacterium } \\
\text { tumefaciens }\end{array}$ & gi|896249 & $9 e-38$ & $45 \%$ & VII.H \\
\hline XF-07B03-g121 & XF0752 & $\begin{array}{l}\text { Conserved } \\
\text { hypothetical } \\
\text { protein (CT145) }\end{array}$ & $\begin{array}{l}\text { Bacillus } \\
\text { subtilis }\end{array}$ & dbj|BAA22321 & $2 e-76$ & $54 \%$ & VIII.A \\
\hline XF-07B03-gl22 & XF0751 & $\begin{array}{l}\text { Ribonuclease D } \\
\text { (RND ou } \\
\text { H10390) }\end{array}$ & $\begin{array}{l}\text { Haemophilus } \\
\text { influenzae }\end{array}$ & $\mathrm{sp|P44442}$ & $1 \mathrm{e}-32$ & $88 \%$ & III.B.4 \\
\hline XF-07B03-gl23 & XF0750 & $\begin{array}{l}\text { Hypothetical } \\
\text { 3,4kDa protein } \\
\end{array}$ & & & & & VIII.B \\
\hline $\mathrm{XF}-07 \mathrm{~B} 03-\mathrm{gl} 24$ & XF0749 & $\begin{array}{l}\text { Virulence } \\
\text { regulator (xrvA) }\end{array}$ & $\begin{array}{l}\text { Xanthomonas } \\
\text { oryzae }\end{array}$ & gi|1360644 & $4 e-28$ & $95 \%$ & VII.H \\
\hline $\mathrm{XF}-07 \mathrm{~B} 03-\mathrm{gl25}$ & & $\begin{array}{l}\text { Hypothetical } \\
3,6 \mathrm{kDa} \text { protein }\end{array}$ & & & & & VIII.B \\
\hline $\mathrm{XF}-07 \mathrm{~B} 03-\mathrm{g} \mid 26$ & & $\begin{array}{l}\text { Hypothetical } \\
4,2 \mathrm{kDa} \text { protein }\end{array}$ & & & & & VIII.B \\
\hline XF-07B03-gl27 & & $\begin{array}{l}\text { Hypothetical } \\
5,2 \mathrm{kDa} \text { protein }\end{array}$ & & & & & VIII.B \\
\hline XF-07B03-gl28 & XF0748 & $\begin{array}{l}\text { Conserved } \\
\text { hypothetical } \\
\text { protein (YGDE) }\end{array}$ & $\begin{array}{l}\text { Haemophilus } \\
\text { influenzae Rd }\end{array}$ & pir||H64168 & $5 e-68$ & $99 \%$ & VIII.A \\
\hline XF-07B03-gl29 & XF0747 & $\begin{array}{l}\text { Hypothetical } \\
26,8 \mathrm{kDa} \text { protein } \\
\end{array}$ & & & & & VIII.B \\
\hline XF-07B03-gl30 & & $\begin{array}{l}\text { Hypothetical } \\
\text { 5,4kDa protein } \\
\end{array}$ & & & & & VIII.B \\
\hline XF-07B03-gl31 & XF0746 & $\begin{array}{l}\text { Hypothetical } \\
10,4 \mathrm{kDa} \text { protein }\end{array}$ & & & & & VIII.B \\
\hline XF-07B03-gl32 & XF0745 & $\begin{array}{l}\text { Hypothetical } \\
4,5 \mathrm{kDa} \text { protein }\end{array}$ & & & & & VIII.B \\
\hline XF-07B03-gl33 & XF0744 & $\begin{array}{l}\text { Conserved } \\
\text { hypothetical } \\
\text { protein }\end{array}$ & $\begin{array}{l}\text { Escherichia } \\
\text { coli }\end{array}$ & dbj|BAA36001 & $5 e-05$ & $70 \%$ & VIII.A \\
\hline XF-07B03-gl34 & $\overline{X F 0743}$ & $\begin{array}{l}\text { Integration host } \\
\text { factor, alpha } \\
\text { subunit (HIMA) }\end{array}$ & $\begin{array}{l}\text { Xanthomonas } \\
\text { campestris }\end{array}$ & gi|2120723 & $6 e-36$ & $97 \%$ & III.A.3 \\
\hline XF-07B03-gl35 & XF0742 & $\begin{array}{l}\text { Phenylalanyl- } \\
\text { tRNA sinthetase } \\
\text { beta chain } \\
\text { (PHET) }\end{array}$ & $\begin{array}{l}\text { Escherichia } \\
\text { coli }\end{array}$ & sp|P07395 & $e-175$ & $100 \%$ & III.B.4 \\
\hline XF-07B03-gl36 & XF0741 & $\begin{array}{l}\text { Phenylalanyl- } \\
\text { tRNA }\end{array}$ & Escherichia & $\mathrm{sp} \mid \mathrm{P} 08312$ & $e-113$ & $100 \%$ & III.B.4 \\
\hline
\end{tabular}




\begin{tabular}{|c|c|c|c|c|c|c|c|}
\hline & & $\begin{array}{l}\text { synthetase alpha } \\
\text { chain (PHES) }\end{array}$ & coli & & & & \\
\hline$\overline{\mathrm{XF}}-07 \mathrm{~B} 03-\mathrm{g} 137$ & & $\begin{array}{l}\text { Hypothetical } \\
3,9 \mathrm{kDa} \text { protein }\end{array}$ & & & & & VIII.B \\
\hline XF-07B03-gl38 & XF0740 & $\begin{array}{l}\text { 50S ribosomal } \\
\text { protein L20 } \\
\text { (RPLT) }\end{array}$ & $\begin{array}{l}\text { Pseudomonas } \\
\text { syringae } \quad p v . \\
\text { syringae }\end{array}$ & sp|P52828 & $2 e-42$ & $100 \%$ & IIII.B.2 \\
\hline Não predita & XF0739 & $\begin{array}{l}\text { 50S ribosomal } \\
\text { protein L35 } \\
\text { (RPMI) } \\
\end{array}$ & $\begin{array}{l}\text { Escherichia } \\
\text { coli }\end{array}$ & sp|P07085 & $7 \mathrm{e}-\overline{14}$ & $98 \%$ & III.B.2 \\
\hline $\mathrm{XF}-07 \mathrm{~B} 03-\mathrm{gl} 39$ & XF0738 & $\begin{array}{l}\text { Hypothetical } \\
3,5 \mathrm{kDa} \text { protein }\end{array}$ & & & & & VIII.B \\
\hline$\overline{X F-07 B 03-g l 40}$ & XF0737 & $\begin{array}{l}\text { Initiation factor } \\
\text { IF-3 (INFC) }\end{array}$ & $\begin{array}{l}\text { Vibrio } \\
\text { cholerae }\end{array}$ & gi|3095162 & $2 e-44$ & $85 \%$ & $\begin{array}{ll}\text { III.C.I } \\
\end{array}$ \\
\hline $\mathrm{XF}-07 \mathrm{~B} 03-\mathrm{gl} 41$ & XF0736 & $\begin{array}{l}\text { Threonyl-tRNA } \\
\text { synthetase } \\
\text { (THRS) }\end{array}$ & $\begin{array}{l}\text { Escherichia } \\
\text { coli }\end{array}$ & $\mathrm{sp} \mid \mathrm{P} 00955$ & 0.0 & $99 \%$ & III.B.4 \\
\hline $\mathrm{XF}-07 \mathrm{~B} 03-\mathrm{gl} 142$ & & $\begin{array}{l}\text { Hypothetical } \\
6,6 \mathrm{kDa} \text { protein }\end{array}$ & & & & & VIIII.B \\
\hline $\mathrm{XF}-07 \mathrm{~B} 03-\mathrm{gl} 43$ & & $\begin{array}{l}\text { Hypothetical } \\
6,1 \mathrm{kDa} \text { protein }\end{array}$ & & & & & VIIII.B \\
\hline$\overline{\mathrm{XF}}-07 \mathrm{~B} 03-\mathrm{g} 144$ & XF0735 & $\begin{array}{l}\text { Hypothetical } \\
14,5 \mathrm{kDa} \text { protein }\end{array}$ & & & & & VIILB \\
\hline XF-07B03-gl45 & & $\begin{array}{l}\text { Hypothetical } \\
\text { 4kDa protein }\end{array}$ & & & & & VIII.B \\
\hline XF-07B03-gl46 & XF0734 & $\begin{array}{l}\text { Hypothetical } \\
4,8 \mathrm{kDa} \text { protein }\end{array}$ & & & & & VIIII.B \\
\hline XF-07B03-gl47 & XF0733 & $\begin{array}{l}\text { Phage-related } \\
\text { tail protein } \\
\text { (gpD) }\end{array}$ & $\begin{array}{l}\text { Pseudomonas } \\
\text { aeruginosa } \\
\text { phage phi CTX }\end{array}$ & gi|4063801 & $4 e-36$ & $76 \%$ & VI.A \\
\hline XF-07B03-g148 & XF0732 & $\begin{array}{l}\text { Phage-related } \\
\text { tail protein } \\
(\mathrm{gpX}) \\
\end{array}$ & $\begin{array}{l}\text { Bacteriophage } \\
P 2\end{array}$ & $\mathrm{sp} \mid \mathrm{P} 51772$ & $7 e-06$ & $87 \%$ & VI.A \\
\hline $\mathrm{XF}-07 \mathrm{~B} 03-\mathrm{gl} 149$ & XF0731 & $\begin{array}{l}\text { Phage-related } \\
\text { tail protein } \\
\text { (gpU) }\end{array}$ & $\begin{array}{l}\text { Bacteriophage } \\
\text { P2 }\end{array}$ & gi|3139113 & $8 \mathrm{e}-24$ & $80 \%$ & VI.A \\
\hline $\mathrm{XF}-07 \mathrm{~B} 03-\mathrm{g} 150$ & XF0730 & $\begin{array}{l}\text { Phage-related } \\
\text { tail protein } \\
\text { (gpT) }\end{array}$ & $\begin{array}{l}\text { Bacteriophage } \\
\text { P2 }\end{array}$ & gi|3139112 & $4 e-13$ & $70 \%$ & VI.A \\
\hline XF-07B03-gl51 & XF0729 & $\begin{array}{l}\text { Conserved } \\
\text { hypothetical } \\
\text { protein }\end{array}$ & $\begin{array}{l}\text { Pseudomonas } \\
\text { aeruginosa }\end{array}$ & gi|5725164 & $1 \mathrm{e}-06$ & $68 \%$ & VIII.A \\
\hline$\overline{\mathrm{XF}-07 \mathrm{~B} 03-\mathrm{gl} 52}$ & XF0728 & $\begin{array}{l}\text { Phage-related } \\
\text { contractile tail } \\
\text { tube protein }\end{array}$ & $\begin{array}{l}\text { Pseudomonas } \\
\text { aeruginosa }\end{array}$ & gi|5725163 & $3 e-29$ & $96 \%$ & VI.A \\
\hline XF-07B03-g153 & XF0727 & $\begin{array}{l}\text { phage-related } \\
\text { contractile tail } \\
\text { sheath protein } \\
\text { (FIR2) }\end{array}$ & $\begin{array}{l}\text { Bacteriophage } \\
\text { PS } 17\end{array}$ & gi|2144176 & $4 e-84$ & $98 \%$ & VI.A \\
\hline
\end{tabular}




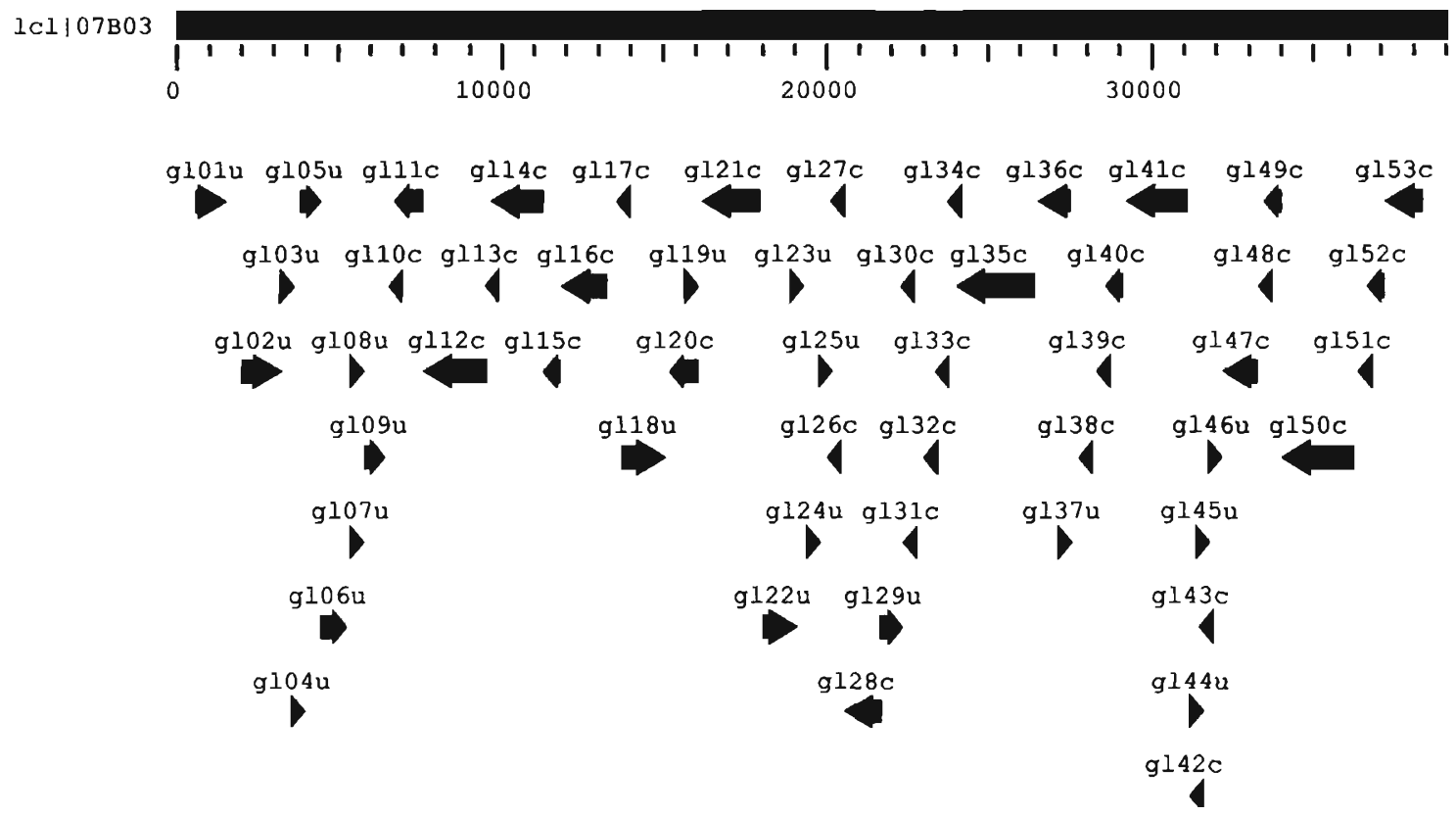

Figura 15: Anotação das ORFs do cosmídeo X0QV-07B03 preditas pelo programa Glimmer. As ORFs estão denominadas como $\mathrm{gl}^{* *} \mathrm{c}(\mathrm{u})$, onde gl significa a ORF Glimmer seguida do número da ORF no cosmídeo e da letra c (ORF em sentido inverso ao cosmídeo) ou u ( $\mathrm{ORF}$ com sentido igual à seqüência do cosmídeo). 
Nesta tabela podemos notar uma região de inserção de fago na região genômica representada pelo cosmídeo $\mathrm{X} 0 \mathrm{QV}-06 \mathrm{C} 06$. Os bacteriófagos podem mediar a evolução e transferência de fatores de virulência e ocasionalmente a aquisição de novas características pelas bactérias. $O$ genoma de Xylella fastiosa contém aproximadamente $7 \%$ de sequiência de fagos, sendo 23 ORFs assim caracterizadas na região anotada por nosso grupo.

Podemos notar novamente uma anotação inconsistente (XF0684) onde somente havia alinhamentos parciais para a determinada proteína ("phage-related protein"), devendo ser revista para "hypothetical protein".

Tabela 20: ORFs anotadas no cosmídeo $\mathrm{X} 0 \mathrm{QV}-06 \mathrm{C} 06$. As ORFs marcadas em vermelho foram excluídas do banco de dados de ORFs de Xylella fastidiosa.

\begin{tabular}{|c|c|c|c|c|c|c|c|}
\hline \multicolumn{2}{|c|}{ ORFs } & \multirow{2}{*}{\begin{tabular}{l}
\multicolumn{1}{|c|}{ Proteína } \\
Hypothetical \\
40,9kDa protein \\
\end{tabular}} & \multirow[t]{2}{*}{ Organismo } & \multirow[t]{2}{*}{ Código \# } & \multirow{2}{*}{$\begin{array}{l}\text { E-value } \\
\text { (Blastp) }\end{array}$} & \multirow{2}{*}{$\begin{array}{c}\% \\
\text { cobert. }\end{array}$} & \multirow{2}{*}{$\begin{array}{l}\text { Cat. } \\
\text { VIII.B }\end{array}$} \\
\hline $\mathrm{XF}-06 \mathrm{C} 06-\mathrm{gl} 34$ & XF0726 & & & & & & \\
\hline $\mathrm{XF}-06 \mathrm{C} 06-\mathrm{gl} 35$ & XF0725 & $\begin{array}{l}\text { Phage-related } \\
\text { tail protein (gpl) }\end{array}$ & $\begin{array}{l}\text { Bacteriophage } \\
P 2\end{array}$ & sp|P26701 & $8 \mathrm{e}-17$ & $80 \%$ & VI.A \\
\hline $\mathrm{XF}-06 \mathrm{C} 06-\mathrm{gl} 36$ & XF0724 & $\begin{array}{l}\text { P hage-related } \\
\text { baseplate } \\
\text { assembly } \\
\text { protein (gpJ) }\end{array}$ & $\begin{array}{l}\text { Bacteriophage } \\
\text { P2 }\end{array}$ & sp|P51767 & $8 e-58$ & $100 \%$ & VI.A \\
\hline $\mathrm{XF}-06 \mathrm{C} 06-\mathrm{gl} 37$ & XF0723 & $\begin{array}{l}\text { Phage-related } \\
\text { baseplate } \\
\text { assembly } \\
\text { protein (gpW) }\end{array}$ & $\begin{array}{l}\text { Pseudomonas } \\
\text { aeruginosa } \\
\text { phage phi CTX }\end{array}$ & $\begin{array}{c}\text { dbj|BAA362 } \\
44\end{array}$ & e-14 & $81 \%$ & VI.A \\
\hline $\mathrm{XF}-06 \mathrm{C} 06-\mathrm{g} \mid 38$ & XF0722 & $\begin{array}{l}\text { Hypothetical } \\
5,2 \mathrm{kDa} \text { protein }\end{array}$ & & & & & VIII.B \\
\hline $\mathrm{XF}-06 \mathrm{C} 06-\mathrm{gl} 39$ & XF0721 & $\begin{array}{l}\text { Proteic killer } \\
\text { suppression } \\
\text { protein (higA) }\end{array}$ & $\begin{array}{l}\text { Dicholobacter } \\
\text { nodasus }\end{array}$ & gi|478169 & $2 \mathrm{e}-19$ & $76 \%$ & VII.H \\
\hline $\mathrm{XF}-06 \mathrm{C} 06-\mathrm{gl} 40$ & XF0720 & $\begin{array}{l}\text { Proteic killer } \\
\text { active protein } \\
\text { (higB) }\end{array}$ & $\begin{array}{l}\text { Dichelobacter } \\
\text { nodosus }\end{array}$ & $\mathrm{sp} \mid \mathrm{Q46561}$ & $8 \mathrm{e}-12$ & $76 \%$ & VI.H \\
\hline $\mathrm{XF}-06 \mathrm{C} 06-\mathrm{gl} 11$ & XF0719 & $\begin{array}{l}\text { Phage-related } \\
\text { baseplate } \\
\text { assembly } \\
\text { protein (gpV) }\end{array}$ & $\begin{array}{l}\text { Bacteriophage } \\
\text { P2 }\end{array}$ & $\mathrm{sp} \mid \mathrm{P} 31340$ & $1 e-21$ & $94 \%$ & VI.A \\
\hline $\mathrm{XF}-06 \mathrm{C} 06-\mathrm{gl} 42$ & XF0718 & $\begin{array}{l}\text { Conserved } \\
\text { hypothetical } \\
\text { protein }\end{array}$ & $\begin{array}{l}\text { Pseudomonas } \\
\text { aeruginosa }\end{array}$ & gi|5725154 & $2 e-14$ & $73 \%$ & VIIII.A \\
\hline $\mathrm{XF}-06 \mathrm{C} 06-\mathrm{gl} 143$ & XF0717 & $\begin{array}{l}\text { Hypothetical } \\
19,6 \mathrm{kDa} \text { protein }\end{array}$ & & & & & VIII.B \\
\hline $\mathrm{XF}-06 \mathrm{C} 06-\mathrm{gl} 44$ & Xf0716 & $\begin{array}{l}\text { Hypothetical } \\
13,4 \mathrm{kDa} \text { protein }\end{array}$ & & & & & VIII.B \\
\hline XF-06C06-g145 & & $\begin{array}{l}\text { Hypothetical } \\
8,1 \mathrm{kDa} \text { protein }\end{array}$ & & & & & VIII.B \\
\hline XF-06C06-gl46 & & $\begin{array}{l}\text { Hypothetical } \\
5,2 \mathrm{kDa} \text { protein }\end{array}$ & & & & & VIII.B \\
\hline
\end{tabular}




\begin{tabular}{|c|c|c|c|c|c|c|c|}
\hline$\overline{\mathrm{XF}-06 \mathrm{C} 06-\mathrm{g} 147}$ & & $\begin{array}{l}\text { Hypothetical } \\
\text { 4kDa protein }\end{array}$ & & & & & VIII.B \\
\hline $\mathrm{XF}-06 \mathrm{C} 06-\mathrm{gl} \mid 48$ & XF0714 & $\begin{array}{l}\text { Hypothetical } \\
67,7 \mathrm{kDa} \text { protein }\end{array}$ & & & & & VIII.B \\
\hline XF-06C06-g149 & & $\begin{array}{l}\text { Hypothetical } \\
\text { 6kDa protein }\end{array}$ & & & & & VIII.B \\
\hline $\mathrm{XF}-06 \mathrm{C} 06-\mathrm{gl} 150$ & XF0713 & $\begin{array}{l}\text { Phage-related } \\
\text { portal protein } \\
\text { (gp4) }\end{array}$ & $\begin{array}{l}\text { Bacteriophage } \\
21\end{array}$ & sp $\{$ P36272 & $1 e-23$ & $93 \%$ & VI.A \\
\hline $\mathrm{XF}-06 \mathrm{C} 06-\mathrm{gl} 151$ & XF0712 & $\begin{array}{l}\text { Hypothetical } \\
20,8 k \text { a protein } \\
\end{array}$ & & & & & VIII.B \\
\hline $\mathrm{XF}-06 \mathrm{C} 06-\mathrm{g} 152$ & XF0711 & $\begin{array}{l}\text { Phage-related } \\
\text { terminase large } \\
\text { subunit (gp2) }\end{array}$ & $\begin{array}{l}\text { Bacteriophage } \\
21\end{array}$ & $\mathrm{sp} \mid \mathrm{P3} 6693$ & $5 e-45$ & $83 \%$ & $\begin{array}{l}\text { VI.A } \\
\text { VI }\end{array}$ \\
\hline $\mathrm{XF}-06 \mathrm{C} 06-\mathrm{g} 153$ & XF0710 & $\begin{array}{l}\text { Phage-related } \\
\text { protein (NOHA) }\end{array}$ & $\begin{array}{l}\text { Escherichia } \\
\text { coli }\end{array}$ & sp|P31061 & $7 \mathrm{e}-10$ & $87 \%$ & VI.A \\
\hline $\mathrm{XF}-06 \mathrm{C} 06-\mathrm{g} 154$ & XF0709 & $\begin{array}{l}\text { Hypothetical } \\
17,3 \mathrm{kDa} \text { protein }\end{array}$ & & & & & VIILB \\
\hline $\mathrm{XF}-06 \mathrm{C} 06-\mathrm{g} 155$ & XF0708 & $\begin{array}{l}\text { Hypothetical } \\
\text { 11,2kDa protein }\end{array}$ & & & & & VIII.B \\
\hline XF-06C06-g156 & XF0707 & $\begin{array}{l}\text { Phage-related } \\
\text { protein }\end{array}$ & & & & & VI.A \\
\hline XF-06C06-g157 & & $\begin{array}{l}\text { Hypothetical } \\
23,2 \mathrm{kDa} \text { protein }\end{array}$ & & & & & VIIII.B \\
\hline $\mathrm{XF}-06 \mathrm{C} 06-\mathrm{g} 158$ & XF0706 & $\begin{array}{l}\text { Hypothetical } \\
\text { 7,3kDa protein }\end{array}$ & & & & & VIII.B \\
\hline $\mathrm{XF}-06 \mathrm{C} 06-\mathrm{gl} 159$ & XF0705 & $\begin{array}{l}\text { Phage-related } \\
\text { protein }\end{array}$ & $\begin{array}{l}\text { Bacteriophage } \\
\text { phi-105 } \\
\text { ORF11 }\end{array}$ & gi|4126648 & $4 e-66$ & $57 \%$ & $\begin{array}{l}\text { VL.A } \\
\end{array}$ \\
\hline $\mathrm{XF}-06 \mathrm{C} 06-\mathrm{g} 160$ & XF0704 & $\begin{array}{l}\text { Phage-related } \\
\text { protein }\end{array}$ & $\begin{array}{l}\text { P43 } \\
\text { [Bacteriophage } \\
\text { APSE-1] }\end{array}$ & gi| 6118038 & $9 \mathrm{e}-15$ & $62 \%$ & VI.A \\
\hline XF-06C06-g161 & Xf0703 & $\begin{array}{l}\text { Hypothetical } \\
13,8 k \text { ka protein } \\
\end{array}$ & & & & & VIII. \\
\hline $\mathrm{XF}-06 \mathrm{C} 06-\mathrm{g} 162$ & XF0702 & $\begin{array}{l}\text { Hypothetical } \\
9,1 \mathrm{kDa} \text { protein }\end{array}$ & & & & & VIII.B \\
\hline XF-06C06-g163 & XF0701 & $\begin{array}{l}\text { Hypothetical } \\
5,5 \mathrm{kDa} \text { protein }\end{array}$ & & & & & VIII.B \\
\hline $\mathrm{XF}-06 \mathrm{C} 06-\mathrm{gl} 64$ & XF0700 & $\begin{array}{l}\text { Hypothetical } \\
18,7 \mathrm{kDa} \text { protein }\end{array}$ & & & & & VIII.B \\
\hline $\mathrm{XF}-06 \mathrm{C} 06$-gl65 & XF0699 & $\begin{array}{l}\text { Hypothetical } \\
\text { 5,8kDa protein }\end{array}$ & & & & & VIII.B \\
\hline $\mathrm{XF}-06 \mathrm{C} 06-\mathrm{g} 166$ & XF0698 & $\begin{array}{l}\text { Hypothetical } \\
8,2 \mathrm{kDa} \text { protein }\end{array}$ & & & & & VIII.B \\
\hline XF-06C06-gl67 & XF0697 & $\begin{array}{l}\text { Hypothetical } \\
\text { 8,0kDa protein }\end{array}$ & & & & & VIIIB \\
\hline $\begin{array}{l}\mathrm{XF}-06 \mathrm{C} 06-\mathrm{gl} 68 \\
\end{array}$ & XF0696 & $\begin{array}{l}\text { Phage-related } \\
\text { repressor protein } \\
\text { (rpcl) }\end{array}$ & $\begin{array}{l}\text { Pseudomonas } \\
\text { aeruginosa } \\
\text { phage D3 }\end{array}$ & $\mathrm{sp} \mid \mathrm{Q} 37906$ & $4 e-15$ & $96 \%$ & VI.A \\
\hline XF-06C06-g169 & & $\begin{array}{l}\text { Hypothetical } \\
3,6 \mathrm{kDa} \text { protein }\end{array}$ & & & & & VIII.B \\
\hline $\mathrm{XF}-06 \mathrm{C} 06$-gl70 & XF0695 & $\begin{array}{l}\text { Hypothetical } \\
8,4 \mathrm{kDa} \text { protein }\end{array}$ & & & & & VIII.B \\
\hline $\mathrm{XF}-06 \mathrm{C} 06-\mathrm{gl} 171$ & & $\begin{array}{l}\text { Hypothetical } \\
12,6 \mathrm{kDa} \text { protein }\end{array}$ & & & & & VIII.B \\
\hline $\mathrm{XF}-06 \mathrm{C} 06-\mathrm{gl} / 72$ & XF0694 & $\begin{array}{l}\text { Hypothetical } \\
6 \mathrm{kDa} \text { protein } \\
\end{array}$ & & & & & VIII.B \\
\hline $\mathrm{XF}-06 \mathrm{C} 06-\mathrm{g} 173$ & XF0693 & $\begin{array}{l}\text { Hypothetical } \\
20,2 \mathrm{kDa} \text { protein }\end{array}$ & & & & & VIII.B \\
\hline
\end{tabular}




\begin{tabular}{|c|c|c|c|c|c|c|c|}
\hline XF-06C06-gl74 & XF0692 & $\begin{array}{l}\text { Hypothetical } \\
14,5 \mathrm{kDa} \text { protein }\end{array}$ & & & & & VIII.B \\
\hline $\mathrm{XF}-06 \mathrm{C} 06-\mathrm{gl} 75$ & XF0691 & $\begin{array}{l}\text { Hypothetical } \\
15,2 \mathrm{kDa} \text { protein }\end{array}$ & & & & & VIII.B \\
\hline $\mathrm{XF}-06 \mathrm{C} 06-\mathrm{gl} 76$ & XF0690 & $\begin{array}{l}\text { Hypothetical } \\
7,7 \mathrm{kDa} \text { protein }\end{array}$ & & & & & VIII.B \\
\hline XF-06C06-gl77 & XF0689 & $\begin{array}{l}\text { Hypothetical } \\
10,2 \mathrm{kDa} \text { protein }\end{array}$ & & & & & VIII.B \\
\hline $\mathrm{XF}-06 \mathrm{C} 06-\mathrm{gl} 78$ & XF0688 & $\begin{array}{l}\text { Hypothetical } \\
7,2 \mathrm{kDa} \text { protein }\end{array}$ & & & & & VIII.B \\
\hline XF-06C06-gl79 & & $\begin{array}{l}\text { Hypothetical } \\
17,7 \mathrm{kD} \text { a protein }\end{array}$ & & & & & VIII.B \\
\hline $\mathrm{XF}-06 \mathrm{C} 06-\mathrm{gl} 80$ & & $\begin{array}{l}\text { Hypothetical } \\
5,5 \mathrm{kDa} \text { protein }\end{array}$ & & & & & VIII.B \\
\hline XF-06C06-gl81 & XF0686 & $\begin{array}{l}\text { Phage-related } \\
\text { protein }\end{array}$ & $\begin{array}{l}\text { Bacteriophage } \\
\text { APSE-1 P5I }\end{array}$ & gi|6118046 & $2 e-82$ & $96 \%$ & VI.A \\
\hline XF-06C06-gl82 & & $\begin{array}{l}\text { Hypothetical } \\
\text { 19kDa protein }\end{array}$ & & & & & VIII.B \\
\hline $\mathrm{XF}-06 \mathrm{C} 06-\mathrm{gl} 83$ & XF0685 & $\begin{array}{l}\text { Phage-related } \\
\text { protein }\end{array}$ & $\begin{array}{l}\text { Bacteriophage } \\
\text { APSE-I P50 }\end{array}$ & gi|6118045 & $2 e-45$ & $97 \%$ & VI.A \\
\hline XF-06C06-gl84 & XF0684 & $\begin{array}{l}\text { Phage-related } \\
\text { protein }\end{array}$ & $\begin{array}{l}B K S-T \\
A 2 \\
\text { rlt }\end{array}$ & $\begin{array}{l}\text { gi|928839 } \\
\text { gi|3005825 } \\
\text { gi| } 1353522\end{array}$ & $2 e-18$ & $\begin{array}{l}39 \% \\
37 \% \\
39 \%\end{array}$ & VI.A \\
\hline
\end{tabular}



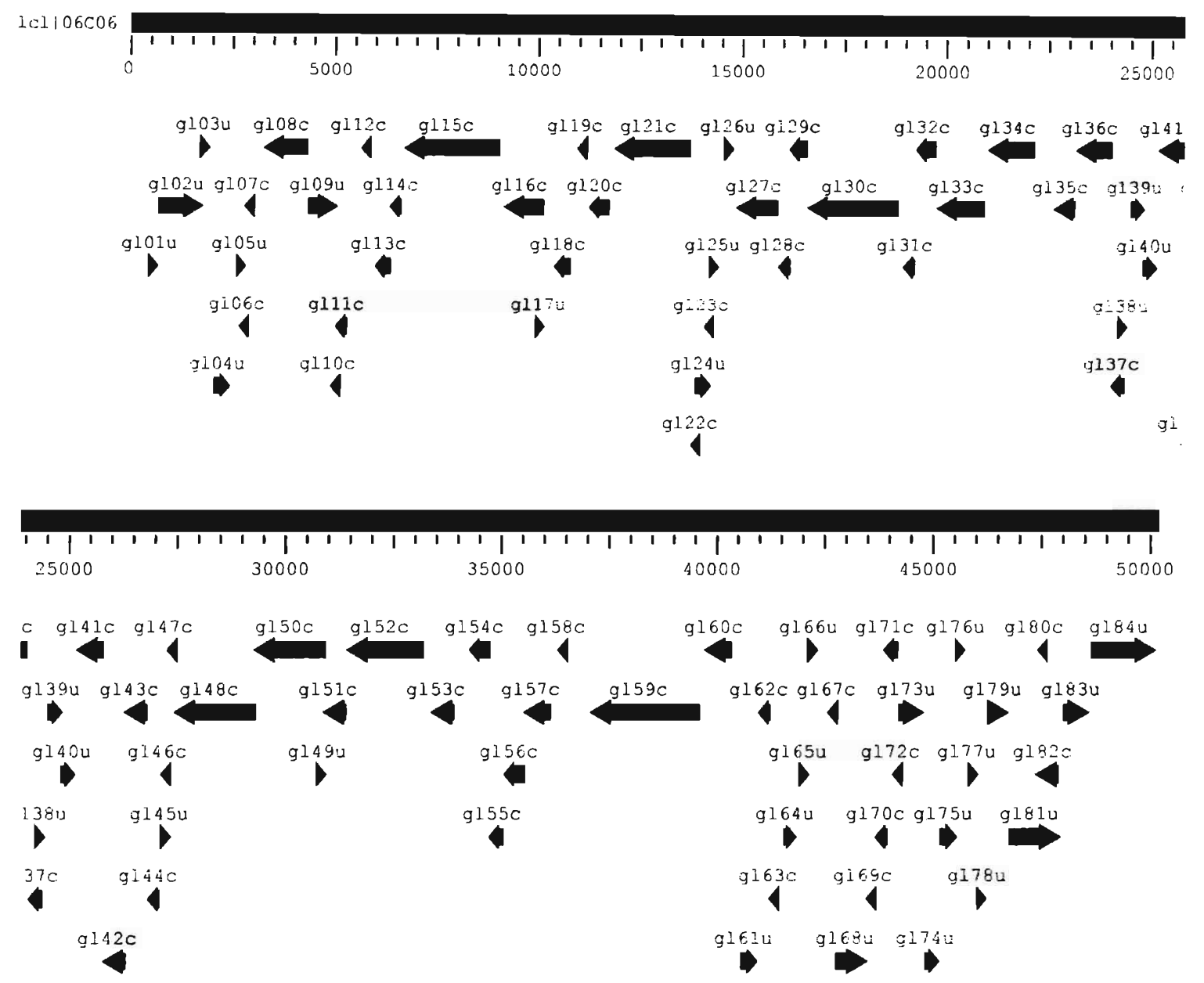

Figura 16: Anotação das ORFs do cosmídeo X0RP-06C06 preditas pelo programa Glimmer. As ORFs estão denominadas como $\mathrm{gl}^{* *} \mathrm{c}(\mathrm{u})$, onde gl significa a ORF Glimmer seguida do número da ORF no cosmídeo e da letra c (ORF em sentido inverso ao cosmídeo) ou u (ORF com sentido igual à seqüência do cosmídeo). 
Tabela 21: ORFs anotadas no cosmídeo XOPF-09G12. As ORFs marcadas em vermelho foram excluídas do banco de dados de ORFs de Xylella fastidiosa.

\begin{tabular}{|c|c|c|c|c|c|c|c|}
\hline \multicolumn{2}{|c|}{ ORFs } & \multirow{2}{*}{\begin{tabular}{l}
\multicolumn{1}{|c|}{ Proteina } \\
$\begin{array}{l}\text { Phage-related } \\
\text { protein }\end{array}$
\end{tabular}} & \multirow{2}{*}{$\begin{array}{l}\text { Organismo } \\
\text { Bacteriophage } \\
\text { APSE-I } \\
\text { protein }\end{array}$} & \multirow{2}{*}{$\begin{array}{l}\text { Código \# } \\
\text { gi|6118039 }\end{array}$} & \multirow{2}{*}{$\begin{array}{c}\text { E-value } \\
\text { (Blastp) } \\
3 \mathrm{e}-17\end{array}$} & \multirow{2}{*}{$\begin{array}{c}\% \\
\text { cobert. } \\
88 \%\end{array}$} & \multirow{2}{*}{$\begin{array}{c}\text { Cat. } \\
\text { VI.A }\end{array}$} \\
\hline XF-09G12-gl01 & XF0682 & & & & & & \\
\hline XF-09G12-gl02 & XF0681 & $\begin{array}{l}\text { Hypothetical } \\
17,6 \mathrm{kDa} \\
\text { protein }\end{array}$ & & & & & VIII.B \\
\hline XF-09G12-g103 & XF0680 & $\begin{array}{l}\text { Phage-related } \\
\text { protein }\end{array}$ & $\begin{array}{l}\text { Bacteriophage } \\
\text { APSE-1 }\end{array}$ & gi|6118036 & e-134 & $98 \%$ & VI.A \\
\hline XF-09G12-gl04 & XF0679 & $\begin{array}{l}\text { Hypothetical } \\
8,6 \mathrm{kDa} \text { protein }\end{array}$ & & & & & VIIl.B \\
\hline XF-09G12-g105 & XF0678 & $\begin{array}{l}\text { Phage-related } \\
\text { integrase (int) }\end{array}$ & $\begin{array}{l}\text { Bacteriophage } \\
\text { D3 }\end{array}$ & gi|6166382 & $5 e-09$ & $92 \%$ & VI.A \\
\hline XF-09G12-gl06 & XF0677 & $\begin{array}{l}\text { Type } 4 \\
\text { fimbriae } \\
\text { assembly } \\
\text { protein (pilZ) }\end{array}$ & $\begin{array}{l}\text { Pseudomonas } \\
\text { aeruginosa }\end{array}$ & gi|972779 & $1 \mathrm{e}-34$ & $92 \%$ & IV.D \\
\hline XF-09G12-gl07 & XF0676 & $\begin{array}{l}\text { DNA } \\
\text { polymerase III, } \\
\text { delta subunit } \\
\text { (HOLB) }\end{array}$ & $\begin{array}{l}\text { Pseudomonas } \\
\text { aeruginosa }\end{array}$ & sp|P52024 & $7 e-18$ & $72 \%$ & III.A.1 \\
\hline XF-09G12-gl08 & XF0675 & $\begin{array}{l}\text { Conserved } \\
\text { hypothetical } \\
\text { protein } \\
(\text { HIO457) }\end{array}$ & $\begin{array}{l}\text { Haemophilus } \\
\text { influenzae }\end{array}$ & sp|P44720 & $1 e-53$ & $98 \%$ & VII.A \\
\hline XF-09G12-gl09 & XF0674 & $\begin{array}{l}\text { Anthranilate } \\
\text { synthase } \\
\text { component I } \\
\text { (TrpE) }\end{array}$ & $\begin{array}{l}\text { Thermus } \\
\text { thermophilus }\end{array}$ & $\mathrm{sp|P05378}$ & $5 e-57$ & $92 \%$ & II.A.4 \\
\hline $\mathrm{XF}-09 \mathrm{G} 12$-gl10 & XF0673 & $\begin{array}{l}\text { 3-oxoacyl- } \\
\text { [ACP] } \\
\text { synthase II } \\
\text { (FABF) }\end{array}$ & Vibrio harveyi & sp|P55338 & e-136 & $99 \%$ & II.E \\
\hline XF-09G12-gll1 & XF0672 & $\begin{array}{l}\text { Acyl carrier } \\
\text { protein (ACPP) }\end{array}$ & $\begin{array}{l}\text { Pseudomonas } \\
\text { aeruginosa }\end{array}$ & $\mathrm{sp} \mid 054439$ & $4 \mathrm{e}-23$ & $94 \%$ & П.Е \\
\hline XF-09G12-gl12 & XF0671 & $\begin{array}{l}\text { 3-oxoacyl- } \\
{[\text { ACP] }} \\
\text { reductase } \\
\text { (FABG) }\end{array}$ & $\begin{array}{l}\text { Escherichia } \\
\text { coli }\end{array}$ & sp|P25716 & $4 e-66$ & $98 \%$ & II.E \\
\hline XF-09G12-gl13 & & $\begin{array}{l}\text { Hypothetical } \\
4,4 \mathrm{kDa} \text { protein }\end{array}$ & & & & & VIII.B \\
\hline XF-09G12-gl14 & XF0670 & $\begin{array}{l}\text { Malonyl CoA- } \\
\text { ACP } \\
\text { transacylase } \\
\text { (FABD) }\end{array}$ & $\begin{array}{l}\text { Salmonella } \\
\text { typhimurium }\end{array}$ & $\mathrm{sp} \mid 085140$ & $5 e-76$ & $99 \%$ & II.E \\
\hline XF-09G12-gl15 & XF0669 & $\begin{array}{l}\text { Pyruvate } \\
\text { dehydrogenase } \\
\text { (ACEE) }\end{array}$ & $\begin{array}{l}\text { Escherichia } \\
\text { coli }\end{array}$ & sp|P06958 & 0.0 & $100 \%$ & I.C.6 \\
\hline XF-09G12-gl16 & & $\begin{array}{l}\text { Hypothetical } \\
7,3 \mathrm{kDa} \text { protein }\end{array}$ & & & & & VIII.B \\
\hline
\end{tabular}




\begin{tabular}{|c|c|c|c|c|c|c|c|}
\hline $\mathrm{XF}-09 \mathrm{G} 12$-gl17 & XF0668 & $\begin{array}{l}\text { Hemolysin- } \\
\text { type calcium } \\
\text { binding protein } \\
\text { (FRPC) }\end{array}$ & $\begin{array}{l}\text { Neisseria } \\
\text { meningitidis }\end{array}$ & sp|P55127 & $3 e-47$ & & $\begin{array}{l}\text { VII.C } \\
\text { IV.A.2 }\end{array}$ \\
\hline $\mathrm{XF}-09 \mathrm{G} 12-\mathrm{gl} 18$ & XF0667 & $\begin{array}{l}\text { Hypothetical } \\
16,2 \mathrm{kDa} \\
\text { protein }\end{array}$ & & & & & VIIILB \\
\hline XF-09G12-gl19 & XF0666 & $\begin{array}{l}\text { Hypothetical } \\
20,8 \mathrm{kDa} \\
\text { protein }\end{array}$ & & & & & VIII.B \\
\hline$\overline{\mathrm{XF}}-09 \overline{\mathrm{G}} 12-\mathrm{g} 120$ & & $\begin{array}{l}\text { Hypothetical } \\
\text { 4kDa protein }\end{array}$ & & & & & VIII.B \\
\hline $\mathrm{XF}-09 \mathrm{G} 12-\mathrm{gl} 1$ & XF0665 & $\begin{array}{l}\text { Hypothetical } \\
\text { 9,3kDa protein }\end{array}$ & & & & & VIII.B \\
\hline$\overline{\mathrm{XF}}-09 \mathrm{G} 12-\mathrm{gl} 22$ & & $\begin{array}{l}\text { Hypothetical } \\
3,8 \mathrm{kDa} \text { protein }\end{array}$ & & & & & VIII.B \\
\hline $\mathrm{XF}-09 \mathrm{G} 12$-gl23 & XF0664 & $\begin{array}{l}\text { Hypothetical } \\
17,4 \mathrm{kDa} \\
\text { protein }\end{array}$ & & & & & VIII.B \\
\hline$\overline{\mathrm{XF}}-09 \mathrm{Gl2}$-gl24 & & $\begin{array}{l}\text { Hypothetical } \\
7,1 \mathrm{kDa} \text { protein }\end{array}$ & & & & & VIII.B \\
\hline XF-09G12-g125 & & $\begin{array}{l}\text { Hypothetical } \\
4,1 \mathrm{kDa} \text { protein }\end{array}$ & & & & & VIII.B \\
\hline $\mathrm{XF}-09 \mathrm{G} 12-\mathrm{g} 126$ & $\mathrm{XF0663}$ & $\begin{array}{l}\text { Hypothetical } \\
19,6 \mathrm{DDa} \\
\text { protein }\end{array}$ & & & & & VIII.B \\
\hline$\overline{X F-09 G 12-g 127}$ & & $\begin{array}{l}\text { Hypothetical } \\
9,7 \mathrm{kDa} \text { protein }\end{array}$ & & & & & VIIIIB \\
\hline $\mathrm{XF}-09 \mathrm{G} 12-\mathrm{gl} 128$ & XF0662 & $\begin{array}{l}\text { Hypothetical } \\
6,7 \mathrm{kDa} \text { protein }\end{array}$ & & & & & VIII.B \\
\hline XF-09G12-gl29 & XF0661 & $\begin{array}{l}\text { Geranyltranstra } \\
\text { nsferase } \\
\text { (farnesyl- } \\
\text { diphosphate } \\
\text { synthase) } \\
\text { (ISPA) }\end{array}$ & $\begin{array}{l}\text { Escherichia } \\
\text { coli }\end{array}$ & sp|P22939 & $6 e-64$ & $88 \%$ & II.D.11 \\
\hline $\mathrm{XF}-09 \mathrm{G} 12-\mathrm{g} \mid 30$ & & $\begin{array}{l}\text { Hypothetical } \\
3,8 \mathrm{kDa} \text { protein }\end{array}$ & & & & & VIIILB \\
\hline $\mathrm{XF}-09 \mathrm{G} 12-\mathrm{gl} 31$ & XF0659 & $\begin{array}{l}\text { Cell cycle } \\
\text { protein (mesJ) }\end{array}$ & $\begin{array}{l}\text { Escherichia } \\
\text { coli }\end{array}$ & sp|P52097 & $4 \mathrm{e}-50$ & $91 \%$ & V.B \\
\hline $\mathrm{XF}-09 \mathrm{G} 12-\mathrm{gl} 32$ & $\overline{\mathrm{XF}} 0658$ & $\begin{array}{l}\text { Hypothetical } \\
6,1 \mathrm{kDa} \text { protein }\end{array}$ & & & & & VIII.B \\
\hline $\mathrm{XF}-09 \mathrm{Gl2}-\mathrm{g} 133$ & XF0657 & $\begin{array}{l}\text { Alkaline } \\
\text { phosphatase } \\
\text { (PHOA) }\end{array}$ & $\begin{array}{l}\text { Halocynthia } \\
\text { roretzi }\end{array}$ & gi 156520 & $3 e-94$ & $93 \%$ & L.B.9 \\
\hline $\mathrm{XF}-09 \mathrm{G} 12-\mathrm{gl} 134$ & XF0656 & $\begin{array}{l}\text { Glutamate } \\
\text { symport protei } \\
\text { (GLTT) }\end{array}$ & $\begin{array}{l}\text { Saccharopolys } \\
\text { pora erythraea }\end{array}$ & pir||S71005 & $1 e-57$ & $92 \%$ & V.A.1 \\
\hline XF-09G12-g135 & & $\begin{array}{l}\text { Hypothetical } \\
3,8 \mathrm{kDa} \text { protein }\end{array}$ & & & & & $\overline{\text { VIIII.B }}$ \\
\hline $\begin{array}{l}\text { XF-09G12-g136 } \\
\end{array}$ & & $\begin{array}{l}\text { Hypothetical } \\
7,7 \mathrm{kDa} \text { protein }\end{array}$ & & & & & VIII.B \\
\hline$\overline{\mathrm{XF}-09 \mathrm{G} 12-\mathrm{g} 137}$ & XF0655 & $\begin{array}{l}\text { Hypothetical } \\
10,2 \mathrm{kDa} \\
\text { protein }\end{array}$ & & & & & VIII.B \\
\hline XF-09G12-gl38 & & $\begin{array}{l}\text { Hypothetical } \\
4,6 \mathrm{kDa} \text { protein }\end{array}$ & & & & & VIIII.B \\
\hline XF-09G12-g139 & XF0654 & $\begin{array}{l}\text { Conserved } \\
\text { hypothetical } \\
\text { Protein }\end{array}$ & $\begin{array}{l}\text { Escherichia } \\
\text { coli }\end{array}$ & gi|1742728 & $9 \mathrm{e}-27$ & $94 \%$ & VIII.A \\
\hline $\mathrm{XF}-09 \mathrm{G} 12-\mathrm{g} 140$ & XF0653 & $\begin{array}{l}\text { Hypothetical } \\
\text { protein }\end{array}$ & $\begin{array}{l}\text { Pseudomonas } \\
\text { aeruginosa }\end{array}$ & gi|2997761 & e-24 & $63 \%$ & VIIII.B \\
\hline
\end{tabular}




\begin{tabular}{|c|c|c|c|c|c|c|c|}
\hline XF-09G12-gl41 & XF0652 & $\begin{array}{l}\text { Peptidyl-prolyl } \\
\text { cis-trans } \\
\text { isomerase } \\
\text { (SLYD) }\end{array}$ & $\begin{array}{l}\text { Escherichia } \\
\text { coli }\end{array}$ & sp|P30856 & $5 e-21$ & $82 \%$ & III.C.1 \\
\hline XF-09G12-gl42 & & $\begin{array}{l}\text { Hypothetical } \\
18,7 \mathrm{kDa} \\
\text { protein }\end{array}$ & & & & & VIII.B \\
\hline XF-09G12-gl43 & & $\begin{array}{l}\text { Hypothetical } \\
10 \mathrm{kDa} \text { protein }\end{array}$ & & & & & VIII.B \\
\hline XF-09G12-gl44 & XF0651 & $\begin{array}{l}\text { Transport } \\
\text { protein } \\
\text { (YXAH ou } \\
\text { S14H) }\end{array}$ & $\begin{array}{l}\text { B acillus } \\
\text { subtilis }\end{array}$ & gi|1176968 & $3 e-48$ & $98 \%$ & V.A.7 \\
\hline XF-09G12-gl45 & & $\begin{array}{l}\text { Hypothetical } \\
\text { 4,3kDa protein }\end{array}$ & & & & & VIII.B \\
\hline XF-09G12-gl46 & XF0650 & $\begin{array}{l}\text { Hypothetical } \\
4,3 \mathrm{kDa} \text { protein }\end{array}$ & & & & & VIII.B \\
\hline XF-09G12-gl47 & XF0649 & $\begin{array}{l}\text { Conserved } \\
\text { hypothetical } \\
\text { protein } \\
\text { (TM1087) }\end{array}$ & $\begin{array}{l}\text { Archaeoglobus } \\
\text { fulgidus }\end{array}$ & gi|2649584 & Se-19 & $88 \%$ & VIII.A \\
\hline XF-09G12-gl48 & XF0648 & $\begin{array}{l}\text { Hypothetical } \\
8,2 \mathrm{kDa} \text { protein }\end{array}$ & & & & & VIII.B \\
\hline XF-09G12-gl49 & & $\begin{array}{l}\text { Hypothetical } \\
5,7 \mathrm{kD} \text { a protein }\end{array}$ & & & & & VIII.B \\
\hline XF-09G12-gl50 & XF0647 & $\begin{array}{l}\text { Endonuclease } \\
\text { III (NTH) }\end{array}$ & $\begin{array}{l}\text { Escherichia } \\
\text { coli }\end{array}$ & sp|P20625 & $1 e-79$ & $99 \%$ & III.A.4 \\
\hline XF-09G12-gl51 & XF0646 & $\begin{array}{l}\text { Hypothetical } \\
15,9 \mathrm{kDa} \\
\text { protein }\end{array}$ & & & & & VIII.B \\
\hline XF-09G12-gl52 & XF0645 & $\begin{array}{l}\text { Hypothetical } \\
4,4 \mathrm{kDa} \text { protein }\end{array}$ & & & & & VIII.B \\
\hline XF-09G12-gl53 & XF0644 & $\begin{array}{l}\text { Peptidyl-prolyl } \\
\text { cis-trans } \\
\text { isomerase } \\
\text { (mip) }\end{array}$ & $\begin{array}{l}\text { Legionella } \\
\text { cherrii }\end{array}$ & gi|2231688 & $7 e-27$ & $99 \%$ & III.C.I \\
\hline XF-09G12-gl54 & & $\begin{array}{l}\text { Hypothetical } \\
3,9 \mathrm{kDa} \text { protein }\end{array}$ & & & & & VIII.B \\
\hline XF-09GI2-gl55 & XF06 $\overline{43}$ & $\begin{array}{l}\text { Hypothetical } \\
6,9 \mathrm{kDa} \text { protein }\end{array}$ & & & & & VIII.B \\
\hline XF-09G12-gl56 & XF0642 & $\begin{array}{l}\text { Hypothetical } \\
7,1 \mathrm{kDa} \text { protein }\end{array}$ & & & & & VIII.B \\
\hline$\overline{\mathrm{XF}}-\overline{09 \mathrm{G} 12-\mathrm{gl} 57}$ & & $\begin{array}{l}\text { Hypothetical } \\
6 \mathrm{kDa} \text { protein }\end{array}$ & & & & & VIII.B \\
\hline XF-09G12-gl58 & XF0641 & $\begin{array}{l}\text { DNA } \\
\text { methyltransfera } \\
\text { se (sfiM) }\end{array}$ & $\begin{array}{l}\text { Streptomyces } \\
\text { fimbriatus }\end{array}$ & gi|2761010 & $4 e-30$ & $88 \%$ & DI.A.5 \\
\hline XF-09G12-gl59 & XF0640 & $\begin{array}{l}\text { Hypothetical } \\
31,6 \mathrm{kDa} \\
\text { protein }\end{array}$ & & & & & VIII.B \\
\hline
\end{tabular}




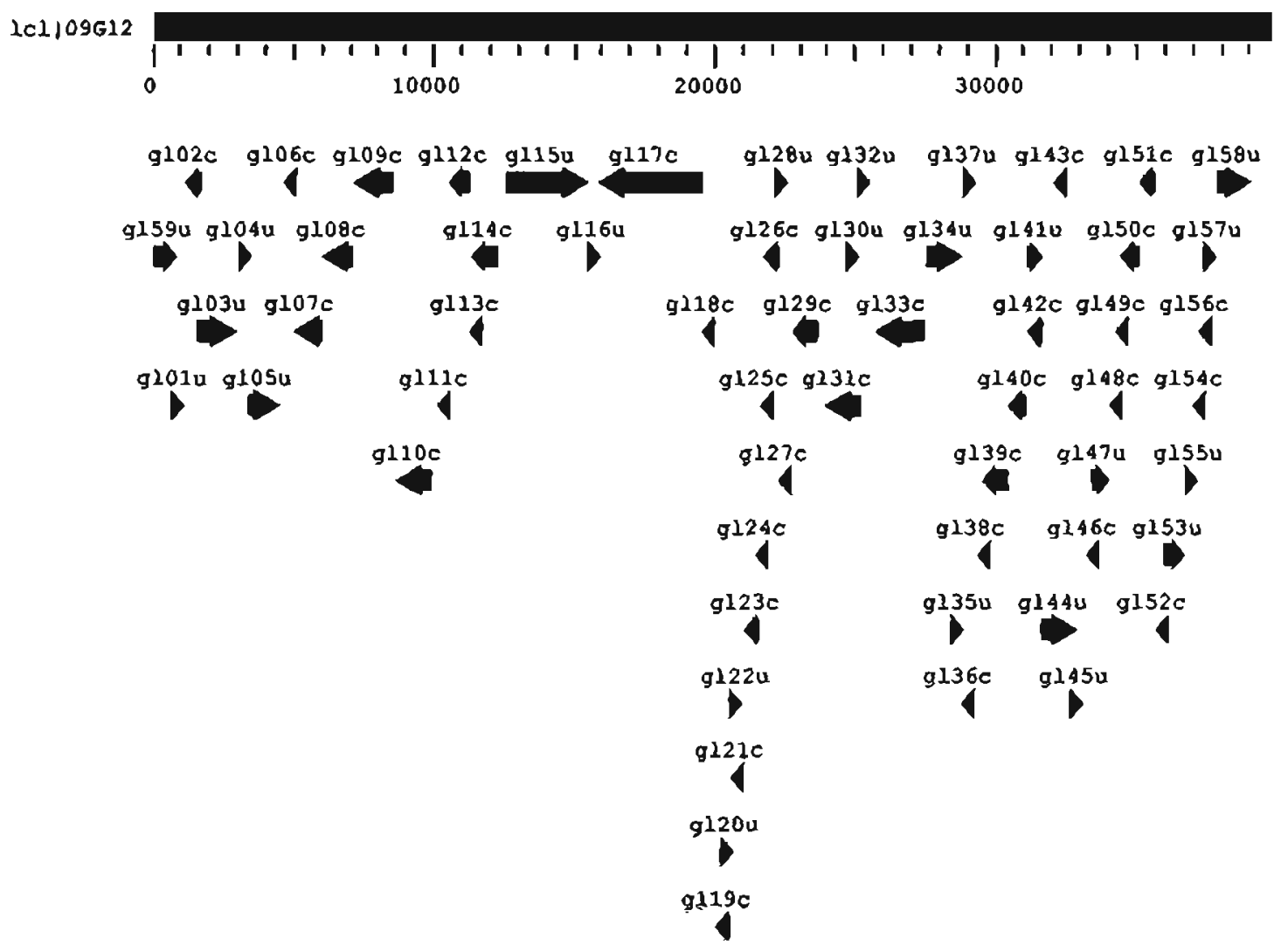

Figura 17: Anotação das ORFs do cosmídeo XOPF-09G12 preditas pelo programa Glimmer. As ORFs estão denominadas como $\mathrm{gl}^{* *} \mathrm{c}(\mathrm{u})$, onde gl significa a ORF Glimmer seguida do número da ORF no cosmídeo e da letra c (ORF em sentido inverso ao cosmídeo) ou u (ORF com sentido igual à sequêencia do cosmídeo). 


\section{Discussão}

A importância da citriculltura no Brasil é indiscutível. Pode ser considerada umas das mais importantes atividades agroindustriais do país, ocupando o $1^{\circ}$ lugar nas estatísticas sobre a fruticultura mundial (FAO, 1996), com um volume físico de produção que alcançou 22,8\% (93,8 milhões de toneladas) da produção total mundial (411,6 milhões de toneladas), à frente das bananas, uvas e maçãs (34).

Todas estas informações evidenciam a importância da citricultura paulista, que coloca o Estado em $1^{\circ}$ lugar mundial na produção de laranja e de suco concentrado e maior exportador internacional de suco concentrado e de farelo de polpa cítrica (para alimentação animal).

Há duas ameaças simultâneas a serem consideradas quanto a propagação de doenças nos citros. A mais óbvia é a destruição direta por conta da praga. A outra, indireta, é a desistência dos produtores rurais. $\mathrm{O}$ abandono da cultura reduz a taxa de renovação de plantas. Ficam as mais velhas e o sistema torna-se menos produtivo.

Torna-se evidente a problemática de doenças que causam a diminuição da produção cítrica em todo o mundo, principalmente no Estado de São Paulo, causando o prejuízo de alguns milhões de dólares.

Um pré requisito para o entendimento da biologia completa de um organismo é a determinação da sequência completa de seu genoma. Com isto nasceu o projeto genoma FAPESP, que se propôs a sequenciar completamente o primeiro fitopatógeno, a bactéria Xylella fastidiosa. A decodificação genética da Xylella fastidiosa representa o caminho para interromper, em médio prazo, a destruição dos pomares.

$\mathrm{O}$ projeto também propiciou a preparação de novos profissionais na área de biologia molecular moderna, utilizada posteriormente em seus próprios projetos de pesquisas, lançando o Brasil na era das modernas tecnologias do DNA.

As estratégias adotadas foram principalmente o seqüenciamento de clones provenientes de bibliotecas de cosmídeos ou de "shotgun" genômico, visando a maior flexibilidade para incorporar uma redundância extensiva e para envolver um grande número de laboratórios separados físicamente.

No total o projeto contou com a participação de 33 laboratórios (32 laboratórios de seqüenciamento e 1 laboratório de bioinformática) localizados em diferentes regiões do Estado de São Paulo (Apêndice B), dentre os quais o nosso laboratório localizado no Instituto de Quimíca da Universidade de São Paulo. 
Uma estratégia do projeto foi a utilização de clones provenientes de uma fragmentação total do genoma de Xylella fastidiosa e clonagem em plasmídeos, caracterizando as denominadas bibliotecas de "shotgun" genômico. Tal metodologia corresponde à mais amplamente utilizada estratégia para o sequenciamento de genomas microbianos (20) incluindo Haemophilus influenzae (1,8 Mb), Helicobacter pylori (1,66 Mb), Archaeoglobus fulgidus (2,18 Mb) e Thermotoga maritima (18, 47, 60 e 71$)$.

Bibliotecas de "shotgun" genômico com diferentes tamanhos de insertos $(0,8$ 2,0 kpb e 2,0-4,5 kpb) foram construídas por nebulização ou digestão enzimática do DNA e clonados em plasmídeos. No início do projeto, foram distribuídos clones das bibliotecas denominadas 00 e 03 para o seqüenciamento pelos grupos anteriormente à distribuição dos cosmídeos. Essas bibliotecas apresentaram sérios problemas com contaminações e redundância e devido a tais fatos foram abandonadas.

Nosso grupo recebeu no total 222 clones provenientes destas bibliotecas "shotgun", sendo seqüenciados 162 clones (73\%) no período entre 20 de abril e 22 de maio de 1998 propiciando a obtenção de 247.120 pb até a distribuição dos primeiros cosmídeos e abandono de tais bibliotecas. Tais clones propiciaram, apesar de todos os problemas em sua construção, padronizações metodológicas e aprendizado nas técnicas que seriam necessárias no decorrer de todo o projeto.

Tal metodologia foi parcialmente abandonada com a distribuição e início do seqüenciamento dos cosmídeo para depois ser novamente retomada para o auxílio no fechamento dos "gaps" ainda existentes, ainda não representados pelos cosmídeos. $O$ seqüenciamento dos clones das bibliotecas de "shotgun" genômico gerou dados que correspondem à uma cobertura de aproximadamente 3,74 vezes o tamanho do genoma da Xylella fastidiosa.

Apesar da desvantagem na montagem de um genoma somente com clones de "shotgun" devido à presença de regiões com grande número de repetiçoes, esta metodologia possui a vantagem da viabilização do seqüenciamento de regiões que codifiquem proteínas que sejam nocivas às bactérias hospedeiras (no caso, Escherichia coli) uma vez que tendem a fragmentar tais regiões. Estas seqüencias se presentes inteiramente dentro de um cosmídeo inviabilizariam o desenvolvimento da bactéria, constituindo um "gap" na biblioteca de cosmídeos

A biblioteca de cosmídeos construída em laboratório da Alemanha pela Prof.Dra. Anete Pereira (UNICAMP) é constituída de 1.056 clones dentre os quais 
113 destes foram utilizados para a montagem do genoma do fitopatógeno. Tais clones foram escolhidos após a construção de um mapa de hibridização, de modo a representar a menor redundância e trabalho possível. Ao total foram seqüenciadas 4.548.306 pares de bases provenientes destes 117 clones, correspondendo à aproximadamente 1,7 vezes o tamanho do genoma (2.679.305 pb), cobrindo $90 \%$ do tamanho deste. Devemos lembrar porém que cada cosmídeo foi considerado "finished" somente após possuir os critérios de qualidade estabelecidos pela coordenação do projeto, fazendo com que este 1,7 vezes de cobertura do genoma sejam representadas somente por bases de alta qualidade dada pelo programa phred.

$\mathrm{O}$ nosso laboratório, denominado de $\mathrm{QV}$, foi responsável pelo seqüenciamento de 7 cosmídeos dentre os quais um cosmídeo (06H03) foi feito em colaboração com o grupo UV (Prof.Dr. Arthur Gruber-USP), resultando na obtenção de aproximadamente $270.000 \mathrm{pb}$ do genoma. Com os primeiros cosmídeos (X0QV07B03 e X0QV-11B08) foram adaptados os protocolos utilizados para os cosmídeos posteriores. A utilização do método físico de nebulização foi o que se mostrou mais eficiente para a obtenção dos fragmentos subclonados em vetor plasmidial. Para o preparo dos templates para o seqüenciamento foram utilizadas as metodologias de lise alcalina (miniprep), PCR de colônia e "Boiling prep". A utilização de fragmentação enzimática realizada na construção de bibliotecas para os cosmídeos X0QV-07B03 e X0QV-11B08 demonstrou-se ineficaz por apresentar insertos quiméricos, dificultando a montagem correta de tais cosmídeos, sendo por isso abandonadas. A metodologia de mini preparação plasmidial (kit QIAGEN ou protocolo adaptado pelo Prof.Dr. Marcelo Bento Soares) fornece templates puros para o seqüenciamento, mas consiste em um método trabalhoso, não favorecendo a agilidade necessária no projeto e portanto sendo utilizada somente enquanto os métodos de PCR de colônia e "Boiling prep" ainda estavam sendo testados e padronizados em nosso laboratório.

A experiência adquirida nos primeiros cosmídeos pode ser notada quando comparamos a necessidade de síntese de um número cada vez menor de primers internos para a finalização de cada cosmídeo (Tabela 02). No início deixávamos que o programa do ABI caracterizasse o "start point" do base caller de cada read, fazendo com que o início de cada read apresentasse leituras inespecíficas devido ás manchas de dyes não incorporados. Considerando essas manchas como bases verdadeiras o assembly tornava-se dificultado e impreciso, além da predição errônea da largura dos picos e distância entre as bases consideradas pelo programa. Nos cosmídeos 
posteriores a lavagem das amostras foi otimizada, melhorando a retirada de dyes não incorporados, e o "start point" foi feito manualmente para todos os reads, melhorando a qualidade das seqüëncias enviadas para o programa de "assembly".

Dentre os 7 cosmídeos seqüenciados, o denominado de X0QV-10F11 caracterizou-se por ser um inserto quimérico. Normalmente a presença de insertos quiméricos é constatada pela presença de vetor em seu interior, no caso Lawrist4, utilizado para a construção da biblioteca de cosmídeos. No caso, porém, tal conclusão se baseou no fato de que tal inserto serviria para a extensão de um contig pré-existente mas se mostrou similar à duas regiões distintas e já bem caracterizadas no genoma, fazendo com que tal inserto fosse considerado quimérico e dividido nos novos cosmídeos denominados de X0QV-10F11 (o inserto de maior tamanho) e X0QV20F1 (o inserto de menor tamanho).

A utilização de cosmídeos como estratégia para o seqüenciamento total de um genoma possui algumas vantagens como a montagem correta de regiões que apresentam repetições de um grande número de nucleotídeos e a possibilidade de iniciar prematuramente a anotação de regiões do genoma já caracterizados pelos cosmídeos. Pelo fato do projeto compreender diversos laboratórios separados fisicamente e pelo objetivo de treinamento de profissionais nas técnicas de biologia molecular, a utilização de tal metodologia foi adequada mas provavelmente superestimada, onde regiões do genoma foram exaustivamente sequenciadas devido à cosmídeos com grande sobreposição e outras não representadas, caracterizando os denominados "gaps".

Com o decorrer do tempo, a produção das sub-bibliotecas plasmidiais e términos de cosmídeos eram metodologias já cotidianas e padronizadas em todos os laboratórios do projeto. Com alguns dados já em mãos e a crescente produção de novos dados partiu-se para uma análise do conteúdo dessas sequências: a caracterização funcional do organismo e seu mecanismo de ação. Iniciou-se portanto, a anotação do genoma da Xylella fastidiosa.

A predição de ORFs foi realizada automaticamente pelo centro computacional do projeto com a utilização do programa GLIMMER. Todas as ORFs preditas deviam ser anotadas, postulando a sua possível função. Para isso, as sequências foram comparadas em um banco de dados público disponíveis pela internet denominado de GenBank através do programa BLAST ou PSI-BLAST. O melhor hit determinou a "função" postulada para a ORF de Xylella fastidiosa. Além da anotação provável da 
função desta ORF, ela também foi categorizada por meio de uma tabela de categorias (Apêndice K) baseada em uma tabela pré-existente de classificação de produtos gênicos de Escherichia coli proposta por Monica Riley (Apêndice J).

A escolha do melhor hit foi feita a critério de cada anotador, baseada sempre em resultados obtidos na utilização de diferentes ferramentas (BLAST, PSI-BLAST, Pfam entre outras) como os valores de e-value e $\%$ de cobertura do read.

O e-value corresponde à probabilidade da similaridade encontrada entre a ORF predita (Query) e a proteína presente no banco de dados (Subject) ser dada ao acaso. Então, quanto menor for este valor maior será a probabilidade de que nossa ORF corresponda à dada proteína. Quanto maior for a \% de cobertura da proteína do banco de dados também maior será o embasamento para que consideremos tal ORF como região codificadora para tal proteína.

A coordenação de anotação, bem como os anotadores, possuiu a preocupação de definir corretamente a nomenclatura utilizada para a caracterização das ORFs preditas. Como as anotações foram baseadas somente em dados de seqüência nucleotídica sem o embasamento de dados bioquímicos experimentais, as ORFs foram sempre caracterizadas como proteínas putativas, alertando ao fato de que não há certeza de que tal proteína realmente exista e seja expressa no genoma de Xylella. Erros propagativos podem ocorrer quando tais cuidados não são observados, uma vez que as anotações feitas serão disponibilizadas em banco de dados públicos servindo de base para futuras anotações.

Em nosso laboratório foram anotados aproximadametne 290 ORFs em 7 cosmídeos, correspondendo a uma extensão linear de $210 \mathrm{~Kb}$ do genoma deste fitopatógeno. Esta anotação corresponde às primeiras tentativas de atribuições hipotéticas às ORFs preditas. Uma segunda etapa da anotação foi então realizada, não mais através de cosmídeos mas sim dividida pelas diferenes categorias de Xylella fastidiosa (Apêndice K) em busca em todo o genoma. Tal etapa foi de essencial importância por permitir aos anotadores uma visão mais abrangente do genoma, possibilitando a procura de genes "faltantes" quando comparados em vias metabólicas (por exemplo) de outras bactérias já conhecidas. Esta segunda etapa de anotação contou também com a importante e maciça colaboração de professores experientes que auxiliaram na busca, no entendimento e possíveis explicações de genes faltantes no genoma do fitopatógeno. 
A intervenção e olhar crítico humano aos dados computacionais obtidos ainda representa um passo essencial para a postulação correta de funções para as ORFs preditas. Casos existiram em que uma ORF foi inicial e computacionalmente considerada como sendo uma determinada proteína mas, quando analizada por um anotador, se verificava apenas matches parciais (baixa $\%$ de cobertura) descaracterizando tal anotação.

Apesar da extensiva verificação das anotações, estas ainda podem e contém erros. Um erro encontrado na região anotada em nosso laboratório se deu para a ORF denominada de XF0853, caracterizada como "two-component system, sensor protein" mas que possuí uma $\%$ de cobertura de apenas $51 \%$, devendo então ser revista para uma possível correção.

Dentre as 290 ORFs anotadas em nosso laboratório nesta primeira fase de anotação, encontramos ORFs representando todas as categorias funcionais em Xylella fastidiosa, como Metabolismo intermediário, de macromoléculas e Biossíntese de pequenas moléculas, entre outras.

Algumas destas ORFs inicialmente preditas pelo programa GLIMMER e anotadas foram posteriormente excluídas do banco de dados de Xylella fastidiosa devido ao fato de não corresponderem à proteínas específicas (hipotéticas) e estarem sobrepostas à outras ORFs maiores hipotéticas ou de função determinada.

Em todo o genoma do fitopatógeno foram encontrados 83 ORFs relacionados à fagos, sendo que 23 destes estavam presentes nos insertos anotados em nosso laboratório. É conhecido que bacteriófagos podem mediar a evolução e transferência de fatores de virulência e ocasionalmenete a aquisição de novas traços pelas bactérias. Como aproximadamente $7 \%$ do genoma de Xylella fastidiosa corresponde à sequiências de fagos e também ao fato de uma grande porcentagem de seqüências relacionadas à fagos terem sido detectadas em um outro patógeno restrito ao sistema vascular de plantas (Spiroplasma citri), podemos considerar esta rota possuindo uma importância particular nessa bactéria.

Uma característica importante após o "término" das anotações foi o valor de apenas $47 \%$ de ORFs para as quais foram atribuídas funções putativas. Em outros genomas anotados esse valor é maior, como 54\% em Thermotoga maritima, 52,5\% em Deinococcus radiodurans e 53,7\% em Neisseria meningitidis. Isso pode ser explicado pelo fato de Xylella fastidiosa ser o primeiro organismo fitopatogênico 
totalmente seqüenciado. Outros fitopatógenos estão sendo seqüenciados, o que propiciará um maior entendimento desses genes "específicos".

Podemos por último considerar que uma anotação jamais se torna completa pois sempre surgirão novos dados que nos façam reanalizar o já anotado, implementando alterações e melhorias no que foi feito.

Concomitantemente ao processo de anotação, o desejo do fechamento do genoma da Xylella fastidiosa levou ao surgimento de diferentes metodologias que se iniciaram a partir de então. $O$ fato de que somente a biblioteca de cosmídeos não proporcionaria o fechamento deste genoma (que possuiu seu tamanho subestimado em aproximadamente $25 \%$ ) fez com que houvesse uma grande retomada do sequenciamento de bibliotecas randômicas denominadas de bibliotecas de "shotgun". Nosso laboratório contribuiu com o sequenciamento de tais clones randômicos, totalizando aproximadamente $419.000 \mathrm{pb}$ do genoma da bactéria.

Outras metodologias que foram utilizadas no intuito de auxílio neste fechamento do genoma são: construção de bibliotecas de fagos, primer walking, sequenciamento diretamento do DNA genômico (31) e a técnica de RDA (Representational Difference Analysis) (52).

O sequenciamento diretamente do DNA genômico da bactéria (30) provou-se de dificil padronização e obtenção de resultados pois a complexidade do genoma e presença de algumas regiões repetitivas desfavorece a metodologia de amplificação por PCR. Obtivemos apenas uma sequência com relativa qualidade de phredPhrap, o que comprovou uma extensão de cosmídeo já caracterizada por outro método. Esta metodologia de sequenciamento foi abandonada.

Outra metodologia já descrita (53) para se encontrar pequenas diferenças entre as sequências de DNA de duas populações, foi utilizada para a formação da denominada "biblioteca de RDA". Este método de "Representational difference analysis" é baseada na subtração de um conjunto de amostra (tester) de um outro conjunto (driver), resultando somente nas diferenças entre elas, que são então amplificados e clonados, formando então a biblioteca.

Foram feitas 4 bibliotecas de RDA denominadas e relacionadas abaixo:

- $\mathrm{AS}$ e $\mathrm{AB}$ : tanto o DNA genômico quanto todos os cosmídeos existentes no projeto foram digeridos com a mesma enzima de restrição (Sau IIIA e BamHI, respectivamente). Os fragmentos obtidos com a digestão dos cosmídeos disponíveis foram utilizados como "driver" e subtraídos dos fragmentos obtidos para 
o DNA genômico ("tester") e amplificados. O resultado desta metodologia foi a representação de fragmentos de DNA presentes somente no DNA genômico que não seriam representados pelos cosmídeos.

- CS e CB: tanto o DNA genômico quanto um set de 81 cosmídeos (que no momento cobriam a maior extensão possível do genoma) no projeto foram digeridos com as mesmas enzimas de restrição descritas acima (SauIIIA e BamHI, respectivamente). Os fragmentos obtidos com a digestão dos cosmídeos disponíveis foram utilizados como "driver" e subtraídos dos fragmentos obtidos para o DNA genômico ("tester") e amplificados. O resultado desta metodologia foi a representação de fragmentos de DNA presentes somente no DNA genômico que ainda não estavam representados pelos cosmídeos feitos até o momento.

$\mathrm{O}$ seqüenciamento da biblioteca $\mathrm{AS}$ ficou sob a responsabilidade de nosso laboratório enquanto que as demais bibliotecas foram entregues para seqüenciamento pelo grupo IL.

Analizando-se as sequências, descobriu-se que elas estavam representadas através de fragmentos curtos ligados entre si, ou seja, as informações derivadas desta biblioteca AS poderiam levar à falsas análises e deduções. Estas bibliotecas bem como tal metodologia foram então abandonadas.

O seqüenciamento de Xylella fastidiosa está terminado e agora esforços devem ser tomados para que haja uma investigação e entendimento de sua complexidade, seu modo de ação e funcionamento. Para isso, estudos funcionais (Apêndice M) foram iniciados em diversos laboratórios podendo levar à médio prazo ao controle e eliminação desta doença que vem atacando nossos pomares. 


\section{Bibliografia}

01.Altschul, S.F \& Gish, W (1996). "Local alignment statistics". Methods of Enzymology . 266:460-480.

02.Altschul, S.F.; Madden, T.H.; Schäffer, A.A.; Zhang, J.; Zhang, Z.; Miller, W and Lipman, D.J (1997). Nucleic Acids Research. 25(17): 3389-3402.

03.Benson, D.A.; Boguski, M.S.; Lipman, D.J.; Ostell, J.; Ouellette, B.F.; Rapp, B. ; ; Weeler, D.L (1999). "Genbank". Nucleic Acids Research. 27(1):12-17.

04.Beretta, M.J.G.; Bach, E.E; Rossetti, V.; Lee, R.F.; Derrick, K.S.(1991a). Serological comparasion of citrus blight from Florida with declinio and citrus variegation chlorosis in Brazil. Summa Phytopathologica, Resumo....v.17, n.1, p.51.

05.Brlansky, R.H., Timmer, L.W., French, W.J., McCoy, R.E (1983). Colonization of the sharphooter vectors, Oncometopia nigricans and Homalodisca coagulata, by xylem-limited bacteria. Phytopathology 73:530-35.

06.Bullock, W.O.; Fernandez, J.M.; and Short, J.M. (1987). BioTechiques 5:376-379.

07.Castro, P.R. de C. e C. (1992). Aspectos fisiológicos do amarelinho. In: ENCONTRO TÉCNICO SOBRE AMARELINHO DOS CITROS. Piracicaba. P.24-6

08.Chang, C.J.; Schaad, N.W. (1982). In vitro antibiotic susceptibility of xylem-limited plant pathogenic rickettsia-bacteria. Phytopathology. 72: 1006, Abstracts.

09. Chang et al (1993). Citrus variegated chlorosis: cultivation of the causal bacterium and experimental reproduction of the disease. P 294-300. Proc. Of the $12^{\text {th }}$ In: CONFERENCE OF THE INTERNATIONAL. IOCV.12. India. Proocedings... p.294-300.

10.Chang, C.J.; Donaldson, R.C. (1993). Xylella fastidiosa: cultivation in chemically defined medium. Phytopathology. 83:192-194.

11.Costa, A,S. et al. (1992). Sintomas da deficiência de molibdênio podem ser parte da resposta da planta infestada à clorose variegada dos citros. Fitopatologia Brasileira, Brasília. v.17, n.2, p.10. 
12.Davis, M.J., Stassi, D.L., French, W.J., Thompson, S. V (1979). Antigenic relationship of several rickettsia-like bacteria involved im plant diseases. Proc. Fourth Int. Conf. Plant Path. Bacteria. pp 311-15. Angers, France: Int. Nac. Rech. Agron.

13.Davis, M.J.; Purcell, A.H.; Thomson, S.V. (1980). Isolation media for the Pierce's disease of grapevines: isolation of the causal bacterium. Phytopathology, 70: 425-429.

14.Davis, M.J., Whitcomb, R.F., Gillaspie, A.G.Jr (1980). Fastidious bacteria of plant vascular tissue and invertebrates (including so-called rickettsia-like bacteria). In The Prokaryotes: A Handbook on Habitats, Isolation, and Identification of Bacteria. ed M.P. Starr, H.O. Stolp, H.G. Truper, A. Balows, H.G. Schlegel. pp 217288. New York/ Heidelberg/ Berlin: Springer-Verlag.

15.Davis, M.J; French, W.J.; Schaad, N.W (1981). Axenic culture of the bacteria associated with phony disease of peach and plum scald. Current microbiology. 5: 311-316.

16.Ewing, B.; Green, P (1998). Base-calling of automated sequence tracer using phred. II Error probabilities. Genome Research, 8(3), 186-94.

17.Ewing, B.; Hillier, L.; Wendl, M.C.; Green, P (1998). Base-calling of automated sequence tracer using phred. I Accuracu assesment. Genome Research, 8(3), 175-85.

18.Fleischman, R.D.; Adams, m.D.; White, O \& 37 other authors (1995). Whole-genome random sequencing and assembly of Haemophilus influenzae Rd. Science 269: 496-512.

19.Focus (1986). 8:2-9.

20.Frangeul, L.; Nelson, K. E.; Buchrieser, C.; Danchin, A.; Glaser, P.; Kunst, F (1999). Cloning and assembly strategies in microbial genome projects. Microbiology 145: 2625-2634.

21.Frazier, N.W, in Proceeding of the International Conference on Virus and Vector on Perennial Hosts, with Special Reference to Vitis (Division of Agricultural Science, University of California), 1995 pp 91-99.

22.French, W.J., Stassi., D.L., Schaad, N.W (1978). The use of immunofluorescence for the identification of phony peach bacterium. Phytopathology. 68:1106-08. 
23.Frohme, $M$ et al (2000). Mapping analysis of the Xylella fastidiosa genome. Nucleic Acids Research 28: 3100-3104.

24.Fry, S.M; Huang J.S and Mieholland, R.D (1994). Isolation and Preliminary Characterization of Extracellular Proteases Produced by Strains of Xylella fastidiosa from Grapevines.

25.Goheen, A.C., Nyland, G., Lowe, S.K. (1973). Association of a rickettsialike organism with Pierce's disease of grapevines and alfafa dwarf and heat therapy of the disease in grapevines. Phytopathology 63:341-45.

26.Goheen, A.C., Raju, B.C., Lowe, S.K., Nyland, G. (1979). Pierce's disease of grapevine in Central America. Plant Dis.Reptr. 63: 788-92.

27.Gordon, D.; Abajian, C.; Green, P. (1998). Consed: a graphical tool for sequence finishing. Genome Research, 8(3), 195-202.

28.Gravena, S., Lopes, J.R.S., Paiva, P.E.B., Yamamoto., P.T., Roberto, S.R (1998). "The Xylella fastidiosa vectors" in "Citrus Variegated Chlorosis", Donadio, L.C. \& Moreira, C.S. (eds), Bebedouro.

29.Greta E. Tyson, B.J. Stojanovic, Richard F. Kuklinsk, Tony J. Divittorino, and Michael L. Sullivan. Scanning Electron Microscopy of Pierce's Disease Bacterium in Petiolar Xylem of Grape Leaves.

30.Harakava, R.; Beretta, M.J.G.; Lee, R.F.; Derrick, K.S.; Jesus, C.B (1994). Detection of Xylella fastidiosa, causal agent of citrus variegated chlorosis, by Western-blotting. Summa Phytopathologica, Resumo., v.20, n. 1, p.53.

31.Heiner, S.R; Hunkapiller, K.L; Chen. S.M; Class. J.I and Chen E.Y. (1998) Sequencing Multimegabase-Template DNA with BigDye Terminator Chemistry. Genome Research: 557-561.

32.Hopkins, D.L. (1989). Xylella fastidiosa: xylem-limited bacterial pathogen of plants. Annual Reviews of Phytopathology. 27: 271-290..

33.Hopkins, D.L; Mollenhawer, H.H (1973). Rickettsia-like bacterium associated with Pierce's Disease of grapes. Science 179:298-300.

34.http://dcc.unicamp.br/genoma/xylella.html

35.http://dcn.davis.ca.us/vme/agri-analysis/xf 995 .html

36.http://fugu.hgmp.mcr.ac.uk/fugu/Lawrist4.html

37.http://info.med.yale.edu/pathol/crittech/ctdnafor.htm

38.http://watson.fapesp.br/Objectiv.htm

39.http://www.biotecnologia.com.br/1hp 4.htm 
40.http://www.cnr.berkeley.edu/xylella/portuguese/brazil.html

41.http://www.dcc.unicamp.br/genoma/organism.html

42.http://www.fapesp.br/n20pag04.htm

43.http://www.ncbi.nlm.nih.gov/BLAST/

44. http://www.tigr.org/softlab/glimmer/glimmer.html

45.Jerpseth, B.; Greener, A.; Short, J.M.; Viola, J. and Kretz, P.L. (1992) Strategies. 5:81-83.

46.Kamper, S.M., French, W.J., de Kloet, S.R. (1985). Genetic-relationships of some fastidious xylem-limited bacteria. Int.J.Syst. Bacteriol. 35:185-88.

47.Klenk, H.P.; Clayton, R.A.; Tomb, J.F \& 48 other authors (1997). The complete genome sequence of the hyperthermophilic, sulphate-reducing archaeon Archaeoglobus fulgidus. Nature 390: 364-370.

48.Lamar, E.E.; and Palmer, E. (1984). Ibid 37:171.

49.Laranjeira, F.F.; Müller, G.W.; Trindade, J.; Silva, L.M.S (1996). Constatação de clorose variegada dos citros (CVC) no estado de Sergipe. Fitopatologia brasileira. v.21, n.4, 521.

50.Laranjeira, F.F.; Pompeu Júnior, J.; Harakava, R.; Figueiredo, J.O.; Carvalho, S.A.; Coletta Filho, H.D (1998). Cultivares e espécies cítricas hospedeiras de Xylella fastidiosa em condição de campo. Fitopatologia Brasileira. v.23, n.2, 147154.

51.Lee, R.F.; Beretta, M.J.G.; Drrick, K.S.; Hooker, M.E (1992). Development of a serological assay for citrus variegated chlorosis, a new disease of citrus in Brazil. Proc. Florida State Hort.Sci. p 32-35.

52.Leite Jr., R.P.; Leite, R.M.V.B.C (1991). Associação de Xylella fastidiosa com a clorose variegada dos citros. Summa phytopathologica, Resumos..., v.17, n.1,p.7.

53.Leite Jr., R.P.; Huang, G.F.; Ueno, B (1997). Ocorrência da clorose variegada dos citros no estado de Santa Catarina. Fitopatologia Brasileira. v.22, n.2, p.214.

54.Lisitsyn N, Lisitsyn $N$ and Wigler M. (1993).Cloning the Differences Between Two Complex Genomes. Science 259: 946-951.

55.Lorow, D \& Jesse, J. (1990) Focus 12:49. 
56.Machado, M.A.; Targon, M.L.P.N.; Beretta, M.J.G.; Laranjeira, F.F.; Carvalho, S.A (1997). Deteç̧ão de Xylella fastidiosa em espécies e variedades de citros sobre-enxertadas em laranja pera com clorose variegada dos citros (CVC). Fitopatologia Brasileira, v. 22, n.1, 30-33.

57.Malavolta, E.; Prates, H.S. (1991). Alterações na composição mineral das folhas de pomares afetados pela anomalia "amarelinha" ou clorose variegada. Laranja. Cordeirópolis, v.12, p.315-329.

58.Malavolta, E.; Prates, H.S.; Pinto, W.B. da S (1992). Notas sobre convivência com o amarelinho. Informativo Coopercitrus, v.10, n.118. p.16-17.

59. Minsavage, G.V.; Thompson, C.M.; Hopkins, D.L.; Leite, R.M.V.B.; Stall, R.E (1994). Development of a Polymerase Chain Reaction protocol for detection of Xylella fastidiosa in plant tissue. Phytopathology. V.84, n.5, p.456-461.

60.Nelson, K.E.; Clayton, R.A.; Gill, S.R. \& 24 other authors (1999). Evidence for lateral gene transfer between Archaea and Bacteria from genome sequence of Thermotoga maritima. Nature 399: 323-329.

61.Paradela Filho, O.; Sugimori, M.H.; Ribeiro, I.J.A.; Garcia Júnior, A; Beretta, M.J.; Harakawa, R; Machado, M.A.; Laranjeira, F.F.; Rodrigues Neto, J.R.; Beriam, L.O.S (1997). Constatação de Xylella fastidiosa em cafeeiro no Brasil. Summa Phytopathologica. v.23, n.1, 46-49.

62.Pierce, N.B, 1982. The California vine disease. U.S. Dept. Agric., Div. of Veg. Pathol. Bull. No.2.

63.Pooler, M.R.; Hartung, J.S (1995). Specific PCR detection and identification of Xylella fastidiosa strains causing citrus variegated chlorosis. Current Microbiology. 31:377-381.

64.Purcell, A.H. Finlay, A.H (1979). Evidence for noncirculative transmission of Pierce's disease bacterium by sharpshooter leafhoppers. Phytopathology 69: 39395.

65.Purcell, A.H., Finlay, A.H. (1979) Pierce's Disease Bacterium: Mechanism of Transmission by Leathopper Vectors. Science 206:839-841.

66.Purcell, A.H. Harris, K.F and Maramovosch, K (1979). In Leafhhopper Vector and Plant Disease Agents, , Eds. (Academic Press, New York), 1979 pp 603625. 
67.Purcell, A. H (1990). Homopteran transmission of xylem-inhabiting bacteria. In Advances in Disease Vector Research, ed KF Harris, 6:243-66. New York; Springer Verlag.

68.Purcell, A.H., Hopkins, D.L. (1996). Fastidious Xylem-Limited Bacterial Plant Pathogens. Annu. Rev. Phytopathol. 34:131-51.

69.Sambrook, J., Fritsch, E.E., Maniats, T. (1989) "Molecular Cloning: A Laboratory Guide", $2^{\text {nd }}$ Edition, Cold Spring Harbor Laboratory Press, Cold Spring Harbor, New York.

70.Severin, H.H.P. Hilgardia 10, 190 (1949).

71.Tomb, J.F.; White, O.; Kerlavage, A.R. \& 39 other authors (1997). The complete genome sequence of the gastric pathogen Helicobacter pylori. Nature 388: 539-547.

72.Vitti, G.C.; Marchi, R.J.; Borella, M.L.; Vaz Filho, D (1989). Estudo de prováveis desequilíbrios nutricionais em pomares cítricos no município de Colina SP, Jaboticabal: FCAV, UNESP. 12p. (mimeografado).

73. Voet, D \& Voet, J.G (1995). "Biochemistry", $2^{\text {nd }}$ edition, John Wiley \& Sons, New York.

74.Watson, J.D.; Gilman, M.; Wibkowski, J.; Zoller, M. (1996). "Recombinant DNA", $2^{\text {nd }}$ edition, Scientific American Books, New York.

75.Wells, J.M.;B.C. Raju, et. al., 1987. Xylella fastidiosa new-genus newspecies. Gram-negative xylem-limited fastidious plant bacteria related to Xanthomonas-ssp. Int. J. Syst. Bacteriol. 37: 136-143.

76. Yanish-Perron, C.; Viera, J.; and Messing, J (1985).Gene. 33:103-199. 


\section{Apêndice}

Neste apêndice estão presentes os dados obtidos na finalização do seqüenciamento do genoma de Xylella fastidiosa como tamanho do genoma, \% de $\mathrm{C}+\mathrm{G}$ e presença de plasmídeos; a estrutura do projeto com os grupos envolvidos; clones seqüenciados; relatórios de término e digestões eletrônicas dos cosmídeos e dos clones de "shotgun" genômico seqüenciados em nosso laboratório; tabelas de classificação para Escherichia coli e para Xylella fastidiosa e protocolos utilizados no decorrer do projeto. 


\section{A. Xylella fastidiosa Genome Features}

Last update: March 27th, 2000

Main chromosome (NCBI AC: AE003849)

Total number of bases: $2,679,305$

$\mathrm{G}+\mathrm{C}: 1,411,300(52.67 \%)$

total number of genes: 2,838

ORFs with functional assignment (protein coding genes): 1,283

ORFs with matches to conserved hypothetical proteins: 310

ORFs without significant database match: 1,083

pXF51 Plasmid (NCBI AC: AE003851)

Total number of bases: 51,158

$\mathrm{G}+\mathrm{C}: 25,358(49.57 \%)$

total number of genes: 64

ORFs with functional assignment (protein coding genes): 30

ORFs with matches to conserved hypothetical proteins: 8

ORFs without significant database match: 24

pXF1.3 Plasmid (NCBI AC: AE003850)

Total number of bases: 1,285

$\mathrm{G}+\mathrm{C}: 714(55.56 \%)$

total number of genes: 2

ORFs with functional assignment (protein coding genes): 1

ORFs with matches to conserved hypothetical proteins: 0

ORFs without significant database match: 1

Phage-related genes

There are 4 prophage regions (XfP1, XfP2, XfP3, XfP4)

There are 83 phage-related genes 


\section{B. Grupos envolvidos no Projeto Genoma Xylella fastidiosa.}

\begin{tabular}{|c|c|c|}
\hline Grupo & Responsável & Localização \\
\hline$\overline{\mathrm{AC}}$ & Prof.Dr Marcos Antonio Machado & Cordeirópolis, SP \\
\hline AG & Prof.Dr. Walter Jose Siqueira & Campinas, SP \\
\hline $\mathrm{BF}$ & Profa.Dra. Eiko Eurya Kuramae Izioka & Botucatu, SP \\
\hline BG & Profa.Dra Catalina Romero Lopes & UNESP- Botucatu, SP \\
\hline $\mathrm{CB}$ & Prof.Dr. Antonio Carlos Boschero & UNICAMP - Campinas, SP \\
\hline $\mathrm{CC}$ & Prof.Dr. Paulo Arruda & UNICAMP - Campinas, SP \\
\hline $\mathrm{CE}$ & Prof.Dr. Siu Mui Tsai & Piracicaba, SP \\
\hline$\overline{\mathrm{CM}}$ & Prof.Dr. Fernando Ferreira Costa & UNICAMP - Campinas, SP \\
\hline EP & Prof.Dr. Luis Eduardo Aranha Camargo & ESALQ - Piracicaba, SP \\
\hline EQ & Profa.Dra. Helaine Carrer & ESALQ - Piracicaba, SP \\
\hline EZ & Prof.Dr. Luiz Lehmann Coutinho & ESALQ - Piracicaba, SP \\
\hline IC & $\begin{array}{l}\text { Prof.Dr. Jððao Carlos Setubal } \\
\text { Prof.Dr. Jððao Meidanis }\end{array}$ & UNICAMP, Campinas, SP \\
\hline$\Pi$ & Profa.Dra. Elza Maria Frias Martins & Instituto Biológico, $\mathbf{S P}$ \\
\hline$\overline{\mathrm{IL}}$ & Prof.Dr. Andrew John George Simpson & Instututo Ludwig, SP \\
\hline IU & Prof.Dr. Paulo Lee Ho & Instituto Butanta, SP \\
\hline JE & Prof. Dra. Eliana G. de Macedo Lemos & Jabuticabal, SP \\
\hline $\mathbf{J J}$ & Prof.Dr. Jesus Aparecido Ferro & Jabuticabal, SP \\
\hline $\mathrm{MC}$ & Prof.Dr. Luiz R. Nunes & Mogi das Cruzes, SP \\
\hline MI & Prof.Dr. Jose Eduardo Krieger & São Paulo, SP \\
\hline MP & Prof.Dr. Homero Pinto Vallada Filho & São Paulo, SP \\
\hline MR & Prof.Dra. Maria Aparecida Nagai & USP - São Paulo, SP \\
\hline $\mathrm{PF}$ & Prof.Dr. Joao Bosco Pesquero & ESPM- São Paulo, SP \\
\hline PM & Prof.Dr. Marcelo R. S. Briones & ESPM - São Paulo, SP \\
\hline $\mathrm{QH}$ & Prof.Dr. Hamza Fahmi Ali El-Dorry & USP - São Paulo, SP \\
\hline$\overline{Q R}$ & $\begin{array}{l}\text { Prof.Dr. Fernando Reinach } \\
\text { Profa.Dra. Ana Cláudia Rasera } \\
\text { Prof.Dr. Ronaldo Quaggio }\end{array}$ & USP- São Paulo, SP \\
\hline QS & $\begin{array}{l}\text { Profa.Dra. Suely Lopes Gomes } \\
\text { Profa.Dra.Aline Maria }\end{array}$ & USP - São Paulo, SP \\
\hline$\overline{\mathrm{QV}}$ & Prof.Dr. Sergio Verjovski-Almeida & USP - São Paulo, SP \\
\hline$\overline{\mathrm{RC}}$ & Prof.Dr. Marco Antonio Zago & USP - Ribeirão Preto, SP \\
\hline $\mathrm{RF}$ & Prof.Dr. Gustavo Henrique Goldman & USP- Ribeirão Preto, SP \\
\hline$\overline{\mathbf{R P}}$ & Prof.Dr. Vanderlei Rodrigues & USP- Ribeirão Preto, SP \\
\hline RU & Profa.Dra. Suzelei de Castro Franca & USP - Ribeirão Preto, SP \\
\hline UI & Profa.Dra. Mayana Zatz & USP - São Paulo \\
\hline UT & Profa. Dra. Marie-Anne Van Sluys & USP - São Paulo \\
\hline UV & Prof.Dr. Arthur Gruber & USP - São Paulo \\
\hline
\end{tabular}


C. Tabela de cosmídeos seqüenciados para a montagem do genoma de Xylella fastidiosa. (Em vermelho, os cosmídeos X0QV)

\begin{tabular}{|c|c|c|}
\hline Cosmídeo & Grupo (s) & Tamanho (bp) \\
\hline $01 \mathrm{A01}$ & PM & 37.022 \\
\hline $01 \mathrm{A03}$ & UV & 39.112 \\
\hline $01 \mathrm{E} 01$ & $\mathrm{AG} / \mathrm{IU}$ & 45.347 \\
\hline $01 \mathrm{G} 04$ & $\mathrm{BG} / \mathrm{IU}$ & 37.493 \\
\hline $01 \mathrm{G} 06$ & CE / UT & 40.185 \\
\hline $01 \mathrm{H09}$ & $\overline{\mathrm{QR}}$ & 37.445 \\
\hline $02 \mathrm{All}$ & $\mathrm{EZ}$ & 38.839 \\
\hline $02 \mathrm{D} 03$ & $\overline{\mathrm{IU}}$ & 44.198 \\
\hline $02 \mathrm{D} 09$ & $\mathrm{QR}$ & 42240 \\
\hline $02 \mathrm{E} 06$ & $\mathrm{QH}$ & 43.113 \\
\hline $02 \mathrm{~F} 10$ & $\mathrm{JJ}$ & 35.283 \\
\hline $02 \mathrm{G} 04$ & $\mathrm{EZ}$ & 40.751 \\
\hline $02 \mathrm{G} 12$ & $\mathrm{QH} / \mathrm{QS}$ & 41.105 \\
\hline $02 \mathrm{HO1}$ & QR & 40.885 \\
\hline $03 \mathrm{~A} 12$ & IC & 18.095 \\
\hline $03 \mathrm{CO} 3$ & $\mathrm{BF} / \mathrm{IL}$ & 39.387 \\
\hline $03 \mathrm{C} 11$ & UV & 39.444 \\
\hline $03 \mathrm{C} 12$ & MC & 39.990 \\
\hline $03 \overline{\mathrm{D} 03}$ & QV & 39.433 \\
\hline 03E01 & $\mathrm{JJ}$ & 40.502 \\
\hline $03 \mathrm{H} 11$ & $\mathrm{CB} / \mathrm{EQ}$ & 45.392 \\
\hline $03 \mathrm{H} 12$ & EP & 37.804 \\
\hline 04A04 & $\overline{\mathrm{QR}}$ & 46.887 \\
\hline $04 \mathrm{~A} 09$ & $\overline{Q V}$ & 38.656 \\
\hline 05A04 & II / IL & 39.821 \\
\hline 05B03 & JE & 46.168 \\
\hline 05B08 & MR & 42.233 \\
\hline 05D08 & $\overline{\mathrm{QH} / \mathrm{QS}}$ & 34.237 \\
\hline $05 \mathrm{E} 12$ & $\overline{Q R}$ & 37.060 \\
\hline $05 \mathrm{~F} 05$ & UT & 39.596 \\
\hline $05 \mathrm{G} 02$ & $\overline{I U}$ & 48.282 \\
\hline $05 \mathrm{G} 03$ & $\mathrm{JE} / \mathrm{JJ}$ & 36.497 \\
\hline 06A08 & $\mathrm{QH}$ & 39.491 \\
\hline $06 \mathrm{C} 06$ & $\mathrm{RP} / \mathrm{RU}$ & 50.172 \\
\hline
\end{tabular}

\begin{tabular}{|c|c|c|}
\hline Cosmídeo & Grupo (s) & Tamanho (bp) \\
\hline $06 \mathrm{ClO}$ & $\mathrm{AG}$ & 38.626 \\
\hline $06 \mathrm{D} 06$ & $\mathrm{MC}$ & 41.170 \\
\hline $06 \mathrm{D} 10$ & $\overline{\mathrm{QR}}$ & 41.346 \\
\hline 06F05 & IL & 36.285 \\
\hline 06G11 & MP & 40.910 \\
\hline $06 \mathrm{H} 03$ & $\mathrm{QV} / \mathrm{UV}$ & 37.463 \\
\hline 07A01 & $\mathrm{CC}$ & 40.347 \\
\hline 07A02 & $\mathrm{CC}$ & 38.685 \\
\hline 07A04 & UI & 40.835 \\
\hline 07A05 & CM & 31.923 \\
\hline 07A07 & UT & 39.751 \\
\hline 07A08 & $\mathbf{R C}$ & 43.858 \\
\hline 07A09 & IC & 43.609 \\
\hline 07A10 & $\overline{\mathrm{QH}}$ & 41.249 \\
\hline $07 \mathrm{Al1}$ & MI & 41.150 \\
\hline $07 A 12$ & MR & 28.312 \\
\hline 07B01 & EQ & 44.966 \\
\hline 07B02 & $\mathrm{PF}$ & 38.509 \\
\hline 07B03 & QV & 39.278 \\
\hline 07B04 & $\mathrm{AC}$ & 44.046 \\
\hline 07B05 & II & 37.809 \\
\hline 07B06 & QS & 43.207 \\
\hline 07B07 & UV & 39.733 \\
\hline 07B08 & PM & 40.496 \\
\hline 07B09 & $\mathrm{JJ}$ & 40.973 \\
\hline 07B10 & $\mathbf{R P}$ & 41.464 \\
\hline 07B11 & $\mathrm{CE}$ & 46.648 \\
\hline 07B12 & $\mathrm{CB}$ & 44.966 \\
\hline $07 \mathrm{C} 01$ & $\overline{E Z}$ & 35.792 \\
\hline $07 \mathrm{C03}$ & EP & 40.392 \\
\hline $07 \mathrm{C} 04$ & JE & 38.509 \\
\hline $07 \mathrm{C06}$ & BG & 15.794 \\
\hline $07 \mathrm{C} 07$ & $\mathrm{BF}$ & 40.745 \\
\hline $07 \mathrm{C} 08$ & IU & 44.409 \\
\hline
\end{tabular}




\begin{tabular}{|c|c|c|}
\hline Cosmídeo & Grupo (s) & Tamanho (bp) \\
\hline $07 \mathrm{C} 09$ & MP & 41.293 \\
\hline $07 \mathrm{C} 10$ & RU & 40.520 \\
\hline $07 \mathrm{C} 12$ & AG & 42.660 \\
\hline $07 \mathrm{E} 05$ & $\mathrm{RC}$ & 45.710 \\
\hline $07 \mathrm{E} 10$ & $\mathrm{JJ} / \mathrm{RP}$ & 37.094 \\
\hline $07 \mathrm{~F} 02$ & IC & 38.207 \\
\hline 07G02 & JE & 36.618 \\
\hline $07 \mathrm{G} 07$ & IC & 36.724 \\
\hline $07 \mathrm{G} 08$ & $\mathrm{JE}$ & 40.792 \\
\hline $07 \mathrm{H} 02$ & $\overline{\mathrm{QS}}$ & 29.524 \\
\hline $07 \mathrm{H} 03$ & $\overline{Q R}$ & 48.325 \\
\hline $07 \mathrm{H} 04$ & QR & 39.395 \\
\hline $08 \mathrm{~A} 02$ & $\mathbf{J J}$ & 40.502 \\
\hline $08 \mathrm{~A} 03$ & QV & 38.066 \\
\hline $08 \mathrm{~A} 04$ & PF & 38.183 \\
\hline $08 \mathrm{D} 10$ & QR & 44.268 \\
\hline 08F01 & $\mathrm{JE} / \mathrm{JJ}$ & 40.828 \\
\hline 08G08 & JJ / RP & 36.928 \\
\hline $08 \mathrm{G} 12$ & QR & 36.829 \\
\hline $09 A 10$ & QR & 44.492 \\
\hline $09 \mathrm{~A} 12$ & $\mathrm{QR}$ & 36.483 \\
\hline $09 \mathrm{C} 12$ & II & 39.196 \\
\hline 09D10 & $\mathrm{CB} / \mathrm{EQ}$ & 39.514 \\
\hline 09D11 & $\mathrm{AC} / \mathrm{BF}$ & 36.480 \\
\hline 09E09 & $\mathrm{JJ}$ & 36.814 \\
\hline
\end{tabular}

\begin{tabular}{|c|c|c|}
\hline Cosmídeo & Grupo (s) & Tamanho (bp) \\
\hline $09 \mathrm{E} 10$ & $\mathrm{BG} / \mathrm{MC}$ & 39.322 \\
\hline 09G12 & $\mathrm{PF} / \mathrm{PM}$ & 39.806 \\
\hline $09 \mathrm{H} 12$ & $\overline{\mathrm{QR}}$ & 37.916 \\
\hline 10B10 & $\mathrm{CB}$ & 37.314 \\
\hline $10 \mathrm{~F} 03$ & $\mathrm{CB} / \mathrm{EQ}$ & 36.284 \\
\hline 10F11 & QV & 34.418 \\
\hline 10G06 & $\mathrm{JJ}$ & 44.999 \\
\hline $10 \mathrm{H} 05$ & $\mathrm{CC}$ & 38.186 \\
\hline $11 \mathrm{~A} 02$ & $\mathrm{CC}$ & 40.077 \\
\hline $11 \mathrm{~A} 03$ & RF & 39.602 \\
\hline $11 \mathrm{A04}$ & $\overline{A C}$ & 47.673 \\
\hline $11 \mathrm{A05}$ & $\mathrm{RF}$ & 36.264 \\
\hline $11 \mathrm{~A} 07$ & MC & 39.356 \\
\hline $11 \mathrm{~A} 08$ & IL & 41.957 \\
\hline $11 \mathrm{~A} 09$ & $\overline{C E}$ & 41.921 \\
\hline $11 \mathrm{~A} 10$ & IL & 31.440 \\
\hline 11B08 & QV & 39.464 \\
\hline $11 \mathrm{D} 03$ & $\mathrm{CM}$ & 46.592 \\
\hline $11 \mathrm{G} 06$ & $\mathrm{CM} / \mathrm{EP}$ & 33.708 \\
\hline $11 \mathrm{H} 05$ & $\mathrm{EQ} / \mathrm{EZ}$ & 35.839 \\
\hline 11D08 & QS & 10.600 \\
\hline $16 \mathrm{C} 06$ & $\mathbf{J J}$ & 50.174 \\
\hline $17 \mathrm{H} 02$ & $\overline{Q S}$ & 10.092 \\
\hline $20 \mathrm{~F} 11$ & $\overline{Q V}$ & 4.437 \\
\hline
\end{tabular}




\section{Bibliotecas de "shotgun" genômico construídas.}

\begin{tabular}{|c|l|l|c|}
\hline Biblioteca & \multicolumn{1}{|c|}{ Vetor } & \multicolumn{1}{|c|}{ Inserto } & Grupo responsável \\
\hline 00 & pBS+ / sítio Pst I & DNA total clivado com Nsi I & INRA \\
\hline 03 & pBS+ / sítio EcoR 1 & DNA total clivado com Mun 1 & INRA \\
\hline 05 & pUC18 / sítio SmaI & Nebulização total & IL \\
\hline 07 & pUC18 / sítio SmaI & Nebulização total & JE \\
\hline 08 & pUC18 / sítio SmaI & Nebulização total (1,5 a 2,5 Kb) & JE \\
\hline 10 & pUC18 / sítio SmaI & Nebulização total $(2,0$ a 4,0 Kb) & JE \\
\hline 11 & m13m19 / sítio SmaI & Nebulização total $(1,5$ a 3,0 Kb) & QR \\
\hline 12 & m13m19/ sítio SmaI & Nebulização total (05 a 1,5 Kb) & QR \\
\hline 13 & Janus / sitio SmaI & Nebulização total $(1,5$ a 3,0 Kb) & QR \\
\hline 14 & Janus / sítio SmaI & Nebulização total $(0,5$ a 1,5 Kb) & QR \\
\hline 15 & pUC18 / sítio SmaI & Nebulização total & IL \\
\hline 16 & pUC18 / sítio SmaI & Nebulização total $(1$ a 2 Kb) & JE \\
\hline 18 & pUC18 / sítio SmaI & Continuação da biblioteca 08 & JE \\
\hline $30 *$ & \multicolumn{2}{|c|}{ Biblioteca de RDA } & UL e QV \\
\hline
\end{tabular}

*As denominadas bibliotecas de RDA foram feitas pelo Dr. Hoheizel em Heidelberg, Alemanha. Subdividiram-se em 4 outras bibliotecas abaixo descritas:

- AS: tanto o DNA genômico quanto todos os cosmídeos existentes no projeto foram digeridos com a enzima de restrição SauIII A.

- AB: tanto o DNA genômico quanto todos os cosmídeos existentes no projeto foram digeridos com a enzima de restrição BamH I.

- CS: tanto o DNA genômico quanto um set de 92 cosmídeos (que no momento cobriam a maior extensão possível do genoma) do projeto foram digeridos com a enzima de restrição SaulII A.

- CB: tanto o DNA genômico quanto um set de 92 cosmídeos (que no momento cobriam a maior extensão possível do genoma) do projeto foram digeridos com a enzima de restrição BamH I. 
E. Tabela de clones das bibliotecas de "shotgun" genômico seqüenciados.

\begin{tabular}{|c|c|c|c|c|}
\hline Biblioteca & \# reads & \# bases & $\begin{array}{c}\text { \# reads aceitos ( } \geq 200 \\
\text { bp e phred } \geq \mathbf{2 0})\end{array}$ & \% reads aceitos \\
\hline 06 & 108 & 20.514 & 40 & $37 \%$ \\
\hline 07 & 3.135 & 1.319 .068 & 2.942 & $93,8 \%$ \\
\hline 08 & 8.125 & 3.096 .536 & 7.128 & $\mathbf{8 7 , 7} \%$ \\
\hline 09 & 159 & 40.064 & 104 & $65,4 \%$ \\
\hline 10 & 8.336 & 3.061 .217 & 7.054 & $84,6 \%$ \\
\hline 11 & 258 & 58.059 & 133 & $51,6 \%$ \\
\hline 12 & 30 & 2.642 & 6 & $20 \%$ \\
\hline 13 & 27 & 10.722 & 26 & $96,3 \%$ \\
\hline 15 & 2.742 & 977.462 & 2.296 & $83,7 \%$ \\
\hline 16 & 2.980 & 1.122 .811 & 2.471 & $82,9 \%$ \\
\hline 18 & 295 & 108.376 & 252 & $85,4 \%$ \\
\hline 20 & 81 & 17.655 & 43 & $93,1 \%$ \\
\hline 30 & 457 & 148.663 & 423 & $\mathbf{8 5 , 7} \%$ \\
\hline TOTAL & $\mathbf{2 6 . 7 3 3}$ & $\mathbf{9 . 9 8 3 . 7 8 9}$ & $\mathbf{2 2 . 9 1 8}$ & \\
\hline
\end{tabular}




\section{F. Primers construídos para a finalização dos cosmídeos.}

F.1 Cosmídeo X0QV- $03 D 03$

Z001: 5' GCT GGA GAC CCC AGA T 3'

Z002: 5' GGC ATT ATT GAA GAC TCA GTT A 3'

Z003: 5' CAG GCA CCA CTG CAA 3'

Z004: 5' AGG GGT TGC TTG GTT 3'

\section{F.2 Cosmídeo X0QV- 04A09}

K001: 5' TTG TTT GAG GTG GGA AT 3'

K002: 5' CAA TCT GCC AAT ACA TAA CA 3'

K003: 5' TGC CTG TCG GTT CAT A 3'

K004: 5' GAT GCG TTC ACT TTG TTT 3'

\section{F.3. Cosmídeo X0QV- 07B03}

P001: 5' GTG CCT CCA CTT CAT CGC GTT 3'

P002: 5' TGC AAG GAT GTC TGC GAC ACC T 3' P003: 5' TGC AAC AGC AGG TGC GGA ATG G 3'

P004: 5' ATC ACC ATC GGT ACT GGC GAT 3' X001: 5' TAT TAC GGA TCT GGA ACT ATG 3' X002: 5' TTG CTC GGA CTA CGC CTG ATC 3' X003: 5' CGG ACA ATT GGA TTT CGC TAC 3' X004: 5' TCC GAT CTC TAT GGA TCG TCC 3' X005: 5' CGA CCT TAC GCG CCT GTT CAC 3' X006: 5' GGC CAT CGG CGT TGT TCG ATG 3' X007: 5' ATG CCT GCA TCA CGT GCT TGA 3' X008: 5' GGC GCA GCG TGC CTA TGA TGC 3' X009: 5' ACA CGT GGC GAC GCG TGA AGC 3' X010: 5' TGC TTA TAT TGG CCG CAA ACA 3' X011: 5' ATG CGG CAT TCT CTG ATA CCA 3' X012: 5' CCG CCT AGC ATC ATC AGG ACA 3' X013: 5' TTG GAT GAT CAG CAA CGC ACC 3' X014: 5' TGG CCG CGT AGG GGA TAT T 3' X015: 5' ACC ATA CGG CAA CAC CTC AT 3' X016: 5' GAC CAT TGG TGT TCT CAG TG 3' X017: 5' AAT CGC CAC GAC CAA GGA GC 3' X018: 5' TTG TAA GCA CGA TTG AAA TCC 3' X019: 5' ACA TGA TTG CTC CAC CGC TCC 3' X020: 5' CGT GCC AGA TAA CAA CAG T 3' 
X021: 5' CGC GAC ATC AAG GTA AA 3'

X022: 5' CCA TTG GCA CAA CTA GAA G 3'

X023: 5' ATG GCC GGT GAA GAG 3'

X024: 5' CGT GCT GAA GAA TGT TG 3'

X025: 5' TCC ACA CCT AGT CCA AAG 3'

X026: 5' CAC CAC AAT GAA ACA ATG 3'

X027: 5' GAT TGC CAT TGT CTT CC 3'

\section{F.4 Cosmídeo X0QV- 08A03}

W001: 5' GCG CGT TGT TGT TTA C 3'

W002: 5' TGT GGG TAC GTA AAA ATT C 3'

W003: 5' CAG GTG ATG TGT GCA TCT 3'

W004: 5' CGC GAG AGA AAC CGT 3'

W005: 5' TGT TGG AGT GCT TGT TG 3'

W006: 5' CAC ACC TCA ATG TGT TCT G 3'

W007: 5' AAC TGT GGA ATG GTA AAG AT 3'

W008: 5' GCC GAG GAA TTA AAA AAG 3'

W009: 5' CAG TTC CCT TCT CTA AAT TTC 3'

W010: 5' GCA TCG AAG TCA TCT TG 3'

\section{F.5 Cosmídeo X0QV- 11B08}

Y001: 5' TAA GAA GCA ATA GTC ATC GTG 3' Y002: 5' TGC CTT CAA GAA ATC GCG GTC 3' Y003: 5' TTC GGC AAG TAT GTT GAT CTG 3' Y004: 5' AAT ATA CTA AAC GCT GGC TTG 3' Y005: 5' GCA GGT GAT ACA GAT CTT TG 3' Y006: 5' GAA GAG CCT GTT TTA TAC G 3' Y007: 5' GCA ATG GAA AGA CTG TCA 3' Y008: 5' TGT GCT ACG TGA TGA TGT C 3' Y009: 5' GCC AGA CGT TTT GAT CC 3' Y010: 5' GGG AGG TAC GGT TTG AG 3' Y011: 5' GAA AAA ACA AAT GAC ACA AC 3' Y012: 5' TAT CGC AGC CTC ATA AG 3' Y013: 5' CAT TGG CTT GGG CTA C 3' Y014: 5' GTC CGG AGA ATC TGT G 3' Y015: 5' GGG TGT TCA CTT GAT TCT 3' 
G. Tabela de clones das bibliotecas de "shotgun" genômico totalmente sequienciados $\left(0^{*} \mathrm{~J}^{* *}\right)$, gaps $\left(00 I^{* *}\right)$ ou clones das bibliotecas lambda $\left(0^{*} \mathbf{L}^{* *}\right)$ - GFSs.

\begin{tabular}{|c|c|c|c|}
\hline Clone & Grupo & \# reads & Tamanho (bp) \\
\hline 00100 & CM / IU & 73 & 2.897 \\
\hline $00 \mathrm{I01}$ & $\mathrm{QH}$ & 17 & 1.699 \\
\hline 00103 & UV & 13 & 1.634 \\
\hline $00 \mathrm{I04}$ & UV & 9 & 1152 \\
\hline $00 \mathrm{I} 06$ & $\Pi \mathrm{U}$ & 359 & 9.909 \\
\hline $00 \amalg 10$ & IU & 0 & 5.416 \\
\hline 00I11 & $\Pi \mathrm{U}$ & 0 & 1.296 \\
\hline 00I12 & $\Pi \mathrm{IU}$ & 44 & 1.873 \\
\hline 00114 & $\mathrm{IU}$ & 0 & $1 . \overline{401}$ \\
\hline $00 \mathrm{~J} 05$ & $\overline{\mathrm{CC}}$ & 203 & 8.338 \\
\hline $00 \mathrm{~J} 06$ & $\mathrm{EZ}$ & 92 & 3.813 \\
\hline $00 \mathrm{~J} 07$ & $\mathrm{EZ}$ & 60 & 2.858 \\
\hline $00 \mathrm{~J} 08$ & $\mathrm{EZ}$ & 52 & 2.022 \\
\hline $00 \mathrm{J09}$ & EP & 10 & 2.188 \\
\hline $00 \mathrm{~J} 10$ & $\mathrm{AC}$ & 71 & 3.435 \\
\hline 00J11 & $\mathrm{CC}$ & 191 & 4.840 \\
\hline $00 \mathrm{~J} 12$ & $\mathrm{CE}$ & 58 & 3.175 \\
\hline $00 \mathrm{~J} 13$ & $\mathrm{EQ}$ & 108 & 2.256 \\
\hline $00 \mathrm{~J} 14$ & IU & 78 & 2.719 \\
\hline $00 \mathrm{~J} 18$ & QV & 55 & 2.805 \\
\hline $00 \mathrm{~J} 19$ & QV & 33 & 2.601 \\
\hline $00 \mathrm{~J} 20$ & $\mathrm{JJ}$ & 57 & 3.160 \\
\hline $00 \mathrm{~J} 21$ & JJ & 5 & 2.224 \\
\hline $00 \mathrm{~J} 22$ & JJ & 4 & 2.224 \\
\hline $00 \mathrm{~J} 23$ & $\mathrm{JJ}$ & 24 & 2.620 \\
\hline $00 \mathrm{~J} 24$ & JJ & 9 & 2.278 \\
\hline $00 \mathrm{~J} 25$ & $\mathrm{JJ}$ & 46 & 2.358 \\
\hline $00 \mathrm{~J} 26$ & JJ & 13 & 1.298 \\
\hline $00 \mathrm{~J} 27$ & $\mathrm{EZ}$ & 63 & 2.166 \\
\hline $00 \mathrm{~J} 28$ & $\mathrm{EZ}$ & 59 & 2.326 \\
\hline $00 \mathrm{~J} 29$ & $\mathrm{EZ}$ & 50 & 2.363 \\
\hline $00 \mathrm{~J} 30$ & $\mathrm{EZ}$ & 53 & 2.125 \\
\hline $00 \mathrm{~J} 31$ & UI & 63 & 1.701 \\
\hline $00 \mathrm{~J} 33$ & UI & 97 & 2.753 \\
\hline $00 \mathrm{~J} 34$ & QV & 37 & 2.169 \\
\hline $00 \mathrm{~J} 37$ & RF & 195 & 3.050 \\
\hline $00 \mathrm{~J} 38$ & EQ & 54 & 2.427 \\
\hline 00J39 & EQ & 89 & 2.291 \\
\hline $00 \mathrm{~J} 40$ & IC & 63 & 3.690 \\
\hline $00 \mathrm{~J} 42$ & $\mathrm{QH}$ & 115 & 2.622 \\
\hline $00 \mathrm{~J} 43$ & $\mathrm{EZ}$ & 101 & 3.819 \\
\hline $00 \mathrm{~J} 45$ & EP & 110 & 3.441 \\
\hline $00 \mathrm{~J} 46$ & QR & 29 & 3.452 \\
\hline $00 \mathrm{~J} 47$ & IU & 34 & 5.071 \\
\hline
\end{tabular}




\begin{tabular}{|c|c|c|c|}
\hline Clone & Grupo & \# reads & Tamanho (bp) \\
\hline $00 \mathrm{~J} 48$ & $\mathrm{CE}$ & 10 & 2.022 \\
\hline $00 \mathrm{~J} 49$ & UI & 42 & 2.116 \\
\hline $00 \mathrm{~J} 50$ & UI & 14 & 2.221 \\
\hline $00 \mathrm{~J} 51$ & UI & 106 & 2.583 \\
\hline $00 \mathrm{~J} 53$ & QV & 41 & 2.710 \\
\hline $00 \mathrm{~J} 57$ & EQ & 100 & 2.305 \\
\hline $00 \mathrm{~J} 58$ & $\mathrm{EQ}$ & 94 & 1.950 \\
\hline $00 \mathrm{~J} 59$ & QS & 243 & 4.215 \\
\hline $00 \mathrm{~J} 60$ & QS & 162 & 2.440 \\
\hline $00 \mathrm{~J} 61$ & IU & 76 & 2.741 \\
\hline $00 \mathrm{~J} 62$ & $\sqrt{\mathrm{E}}$ & 158 & 2.847 \\
\hline $00 \mathrm{~J} 65$ & IL & 6 & 334 \\
\hline $00 \mathrm{~J} 66$ & $\mathrm{CC}$ & 395 & 2.233 \\
\hline $00 \mathrm{~J} 67$ & $\mathrm{QV}$ & 68 & 1.472 \\
\hline $00 \mathrm{~J} 68$ & $\mathrm{IU}$ & 59 & 1.762 \\
\hline 00J69 & $\mathbf{J J}$ & 8 & 2.096 \\
\hline $00 \mathrm{~J} 70$ & IU & 70 & 3.056 \\
\hline $00 \mathrm{~J} 71$ & IU & 46 & 2.440 \\
\hline $00 \mathrm{~J} 72$ & IU & 296 & 2.351 \\
\hline $00 \mathrm{~J} 73$ & IU & 64 & 3.721 \\
\hline $00 \mathrm{~J} 74$ & JJ & 403 & 3.009 \\
\hline 04L02 & $\mathrm{CC}$ & 414 & 13.663 \\
\hline 04L31 & $\mathrm{CC}$ & 508 & 13.918 \\
\hline $07 \mathrm{~J} 24$ & QV & 1 & 1.989 \\
\hline $08 \mathrm{~L} 88$ & $\mathrm{CC}$ & 424 & 11.764 \\
\hline $09 \mathrm{~L} 11$ & $\mathrm{CC}$ & 404 & 15.536 \\
\hline $10 \mathrm{~J} 64$ & QV & 36 & 2.097 \\
\hline 20L02 & $\mathrm{CC}$ & 312 & 12.456 \\
\hline $21 \mathrm{~L} 40$ & $\mathrm{CC}$ & 396 & 13.333 \\
\hline $21 \mathrm{L77}$ & $\mathrm{CC}$ & 386 & 16.662 \\
\hline
\end{tabular}




\section{H. Cosmídeos X0QV}

\section{H.1. Cosmídeo X0QV-03D03}

- Cronograma

08-jan-1999

Not close to finished

03D03/15-jan-1999

Finished.

FAPESP not yet notified.

14-jan-1999

Close to finished.

03D03/Thu 11-Feb-1999

FAPESP not yet notified.

Finished

- Preliminary certification report for cosmid 03D03

Date: Thu 11-Feb-1999

Read composition: 1100 reads;

CC-11A02 : 1 read

LL-11A10 : 1 read

QV-06G05 : 1 read

MR-07A12: 1 read

QV-07B03 : 200 reads

QH-07A10 : 1 read

RF-11A05: 3 reads

QR-07H03 : 36 reads

RP-07B10 : 50 reads

QR-07H04 : 221 reads

UT-07A07 : 23 reads

QV-02H05 : 1 read

plasmid : 79 reads

QV-03D03 : 482 reads

Contig size: $40587 \mathrm{bp}$

Insert size: 39433 bp (excludes lawrist and/or cosmid extensions)

LAWRIST LOCATIONS:

Left : first base after LAU1 $=555$

Right : last base before LAU2 $=39987$

EXPECTED ERROR RATE: $0.00 / 10000$ bp

LOW CONSENSUS QUALITY (LCQ) REGIONS:

TOTAL: 0

HIGH QUALITY DISCREPANCIES (HQD):

TOTAL: 0

POSITIONS NOT CONFIRMED ON BOTH STRANDS (NCBS):

TOTAL: 0

CONCLUSION: Cosmid FINISHED 
- Digestão com enzimas de restricão (BamH I, EcoR I e Hind III) e digestão eletrônica do cosmídeo X0QV-03D03

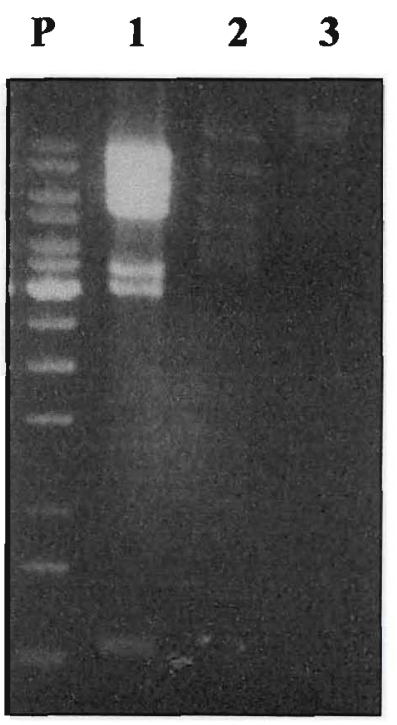

Figura 18: Eletroforese em gel de agarose 1.2\%. P: Padrão de tamanho molecular de $1 \mathrm{~Kb} ; 1,2$ e 3: Cosmídeo X0QV-03D03 digerido respectivamente com BamH I, EcoR I e Hind III.

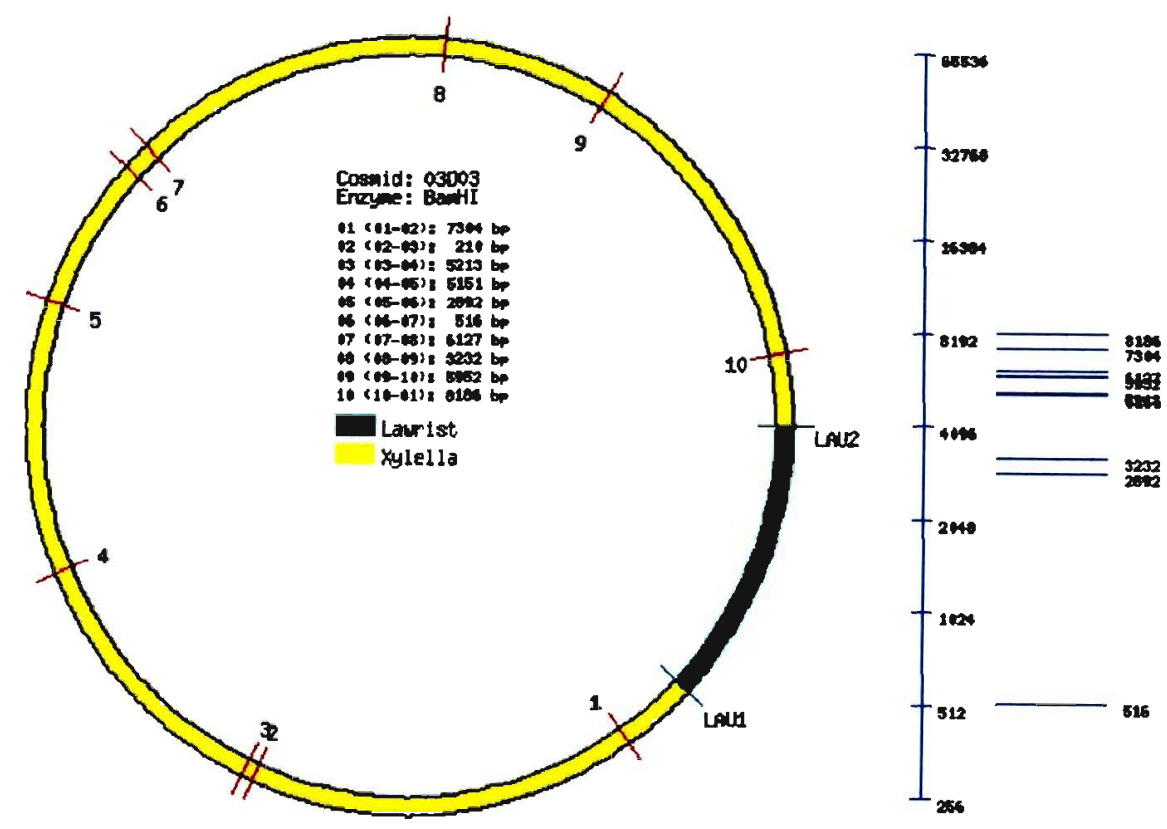



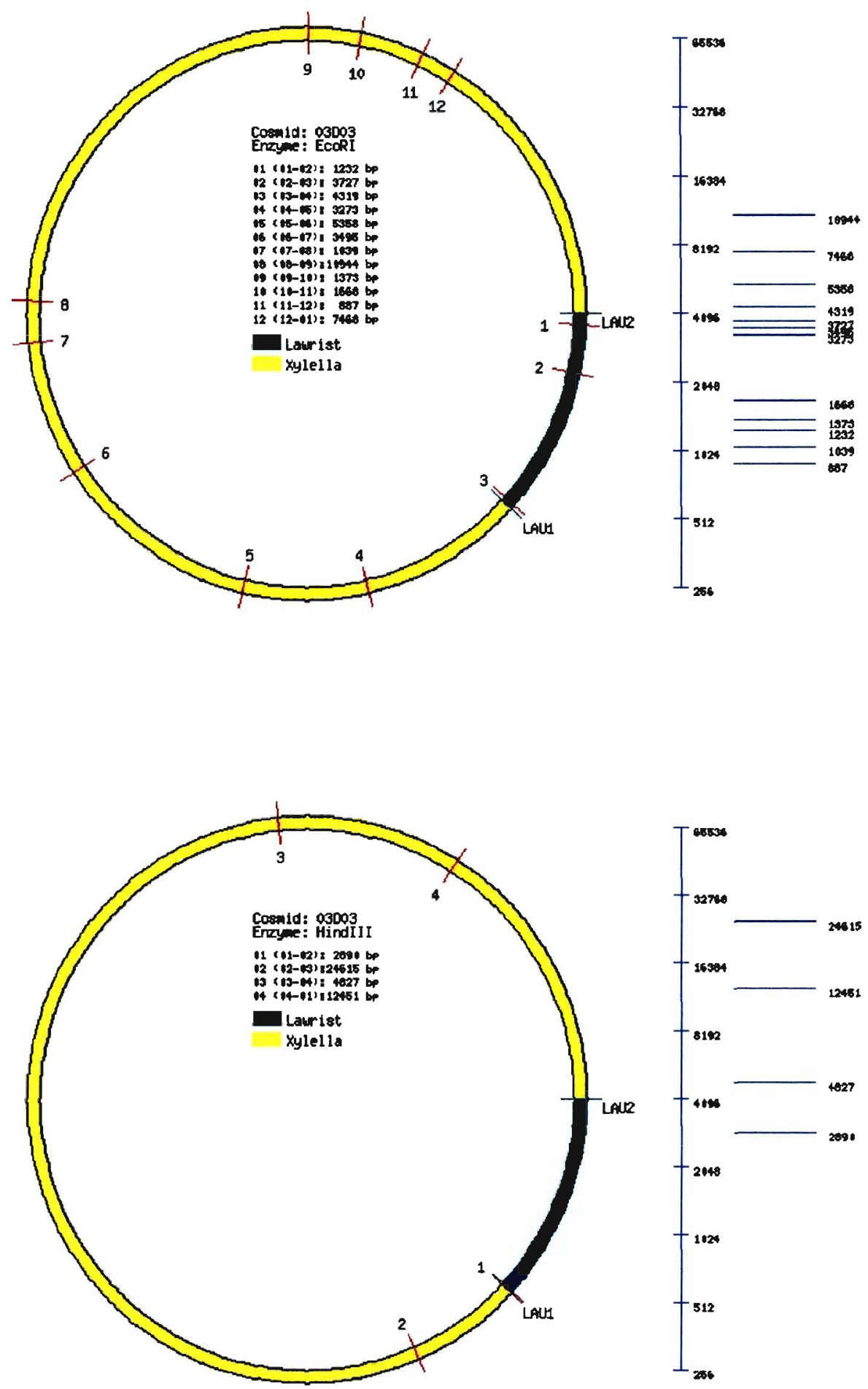


\section{H.2. Cosmídeo X0QV-04A09}

- Cronograma

04A09/Mon 22-Feb-1999

04A09/Thu 11-Feb-1999

Finished

One-contig

04A09/Mon 22-Feb-1999

04A09/Wed 10-Feb-1999

Close to Finished

One-contig

04A09/Fri 12-Feb-1999

Close to Finished

04A09/Fri 05-Feb-1999

Submitted

04A09/Thu 11-Feb-1999

04A09/Fri 05-Feb-1999

Close to Finished

Submitted

- Preliminary certification report for cosmid 03D03

Date: Mon 22-Feb-1999

READ COMPOSITION: 1272 reads;

CE-04A09 : 2 reads

PM-01A01 : 186 reads

QR-01H09 : 205 reads

QR-09H12 : 1 read

QV-04A09 : 782 reads

plasmid : 96 reads

Contig size: $40350 \mathrm{bp}$

Insert size: 38656 bp (excludes lawrist and/or cosmid extensions)

LAWRIST LOCATIONS:

Left : first base after LAU2 $=511$

Right : last base before LAU1 $=39166$

EXPECTED ERROR RATE: 0.02 / 10000 bp

LOW CONSENSUS QUALITY (LCQ) REGIONS:

TOTAL: 0

HIGH QUALITY DISCREPANCIES (HQD):

TOTAL: 0

POSITIONS NOT CONFIRMED ON BOTH STRANDS (NCBS):

TOTAL: 0

CONCLUSION: Cosmid FINISHED

END OF ANALYSIS 
- Digestão com enzimas de restrição (BamH I, EcoR I e Hind III) e digestão eletrônica do cosmídeo X0QV-04A09

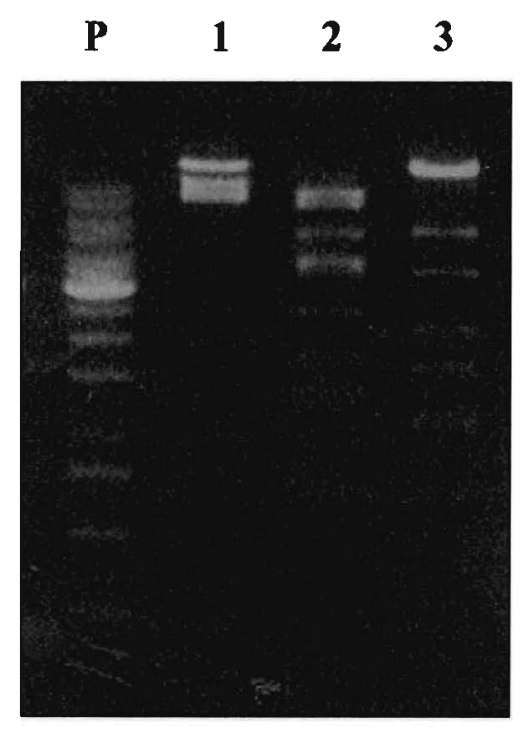

Figura 19: Eletroforese em gel de agarose 1.2\%. P: Padrão de tamanho molecular de 1Kb; 1, 2 e 3: Cosmideo X0QV-04A09 digerido respectivamente com BamH I, EcoR I e Hind III.

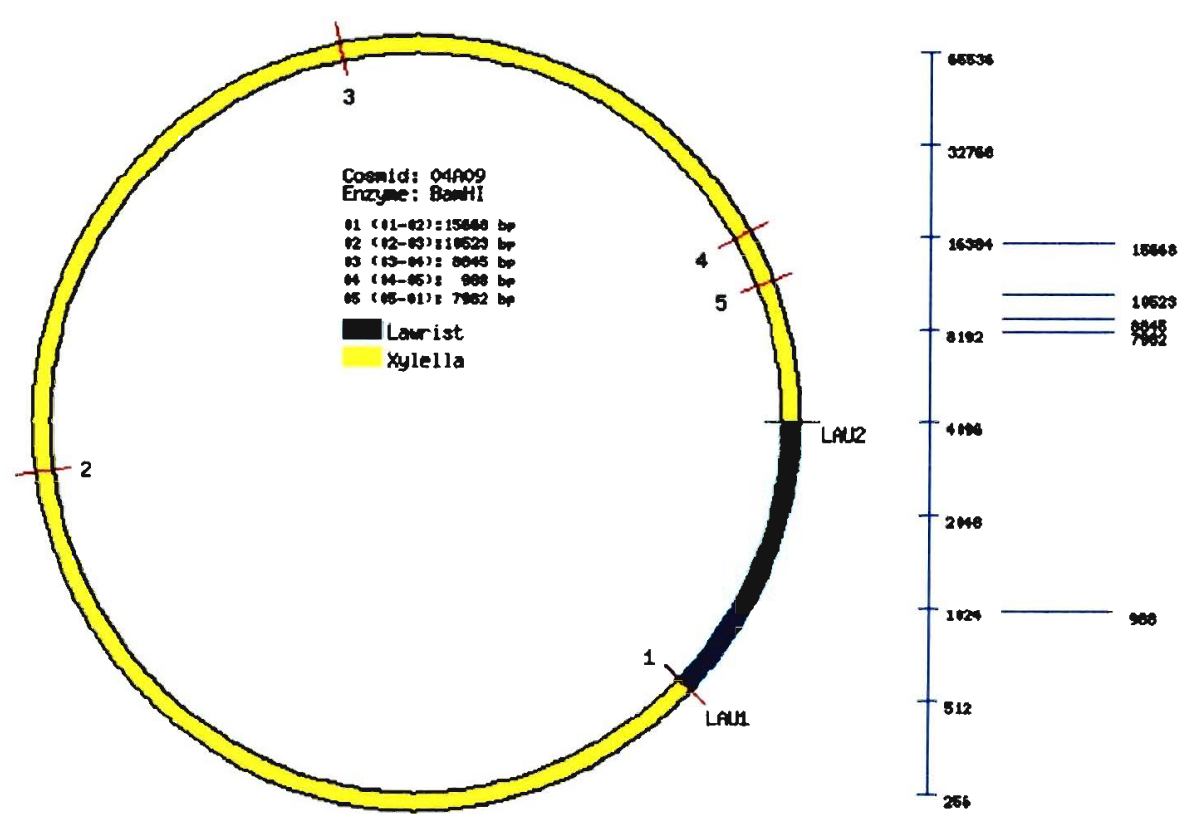



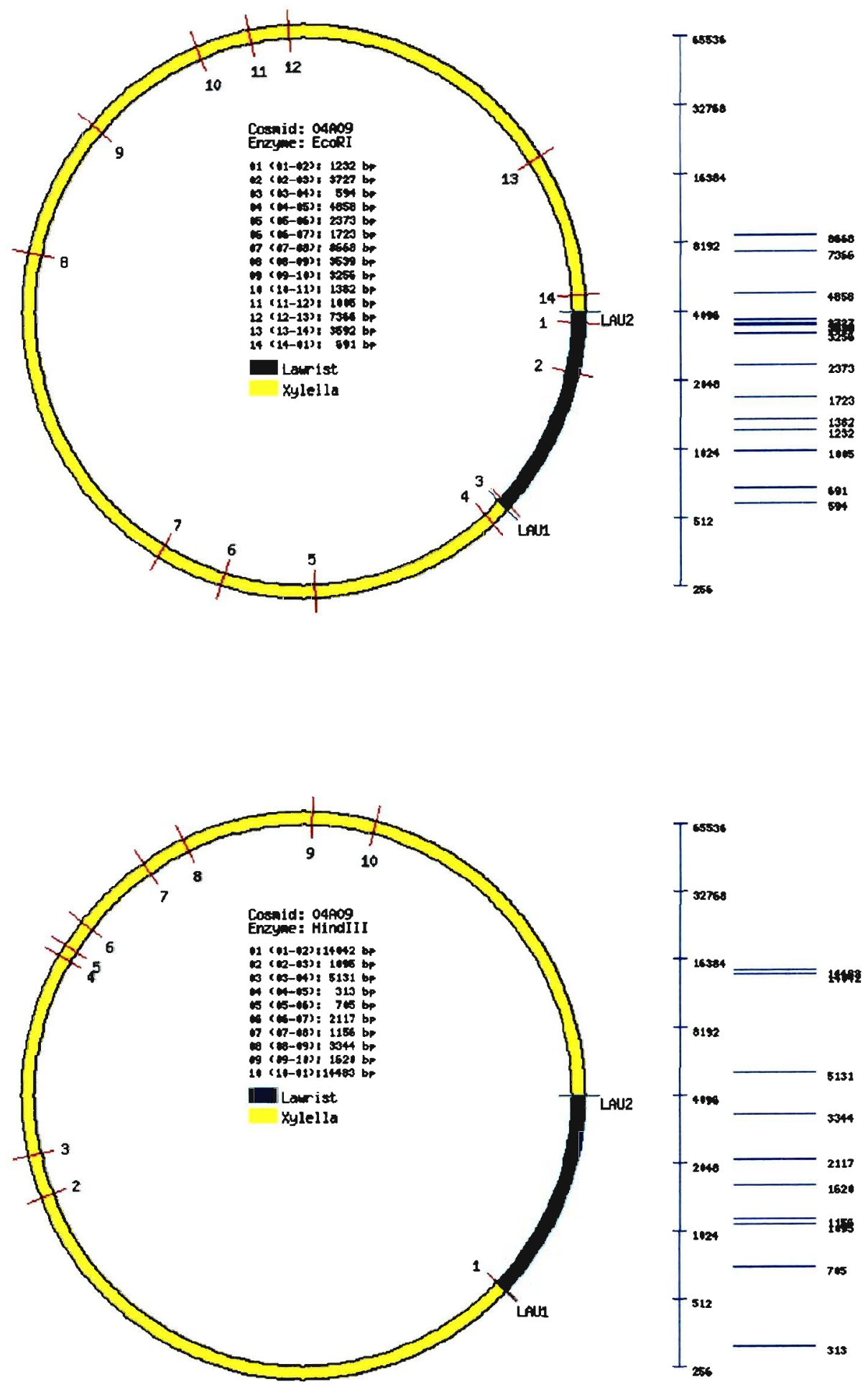


\section{H.3. Cosmídeo X0QV-06H03}

- Cronograma

06H03/Mon 02-Aug-1999

06H03/Mon 19-Jul-1999

Finished

One-contig

06H03/Wed 21-Jul-1999

06H03/Mon 12-Jul-1999

One-contig

One-contig

- Preliminary certification report for cosmid 06H03

Date: Mon 02-Aug-1999 14:36:42

FILE SUBMITTED: 06H03.tar.gz

READ COMPOSITION: 1416 reads;

IL-06H03 : 2 reads

MC-06H03 : 2 reads

QS-07H02 : 466 reads

QV-06H03 : 312 reads

UV-06H03 : 464 reads

plasmid : 170 reads

Contig size: $37463 \mathrm{bp}$

Insert size: 37463 bp (excludes lawrist and/or cosmid extensions)

LAWRIST LOCATIONS:

Left : first base after LAU2 $=1$

Right : last base before LAU1 $=37463$

EXPECTED ERROR RATE: $0.00 / 10000 \mathrm{bp}$

LOW CONSENSUS QUALITY (LCQ) REGIONS:

TOTAL: 0

HIGH QUALITY DISCREPANCIES (HQD):

TOTAL: 0

POSITIONS NOT CONFIRMED ON BOTH STRANDS (NCBS):

TOTAL: 0

CONCLUSION: Cosmid FINISHED

E. Coli contamination:

None detected.

END OF ANALYSIS 
- Digestão com enzimas de restrição (BamH I, EcoR I e Hind III) e digestão eletrônica do cosmídeo X0QV-06H03

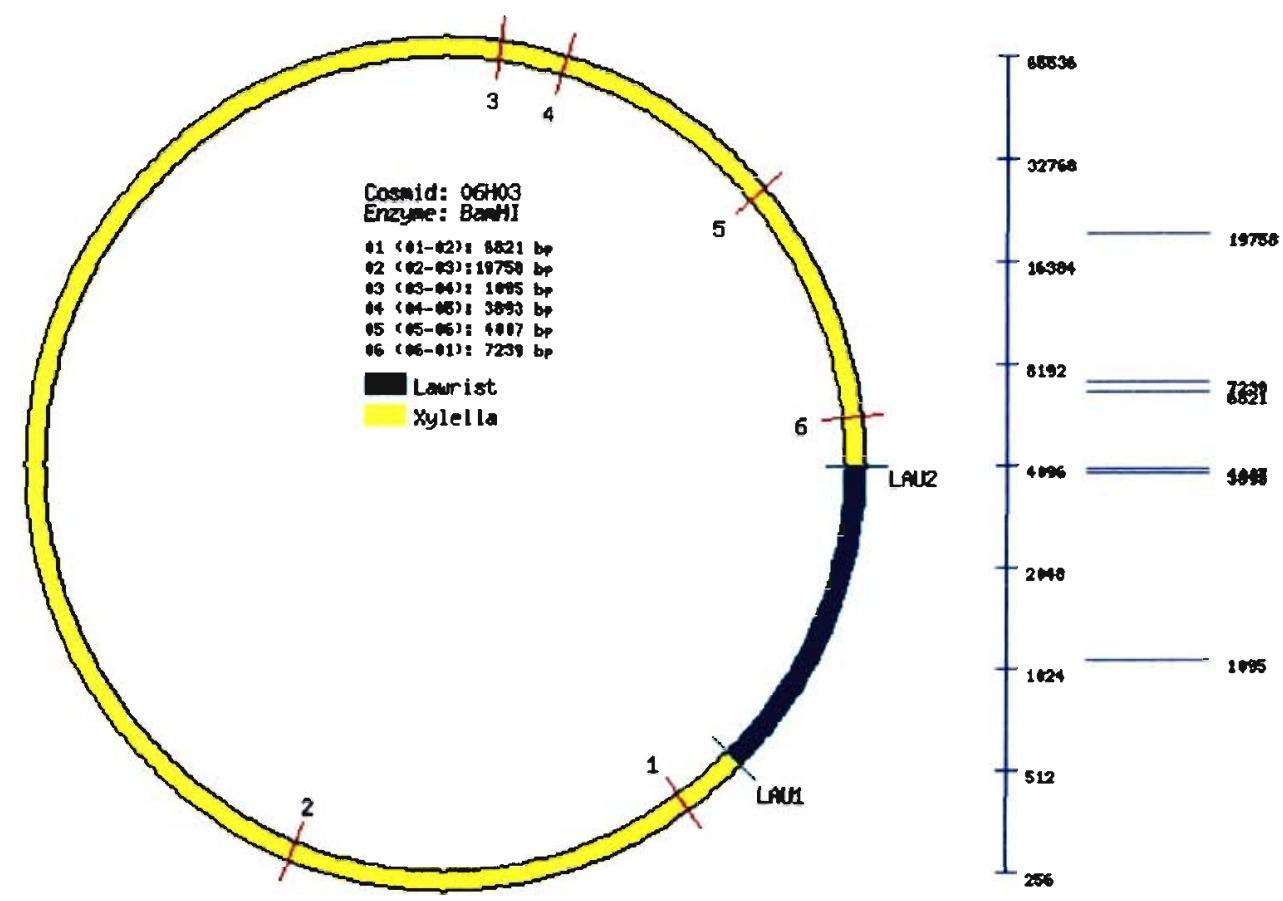



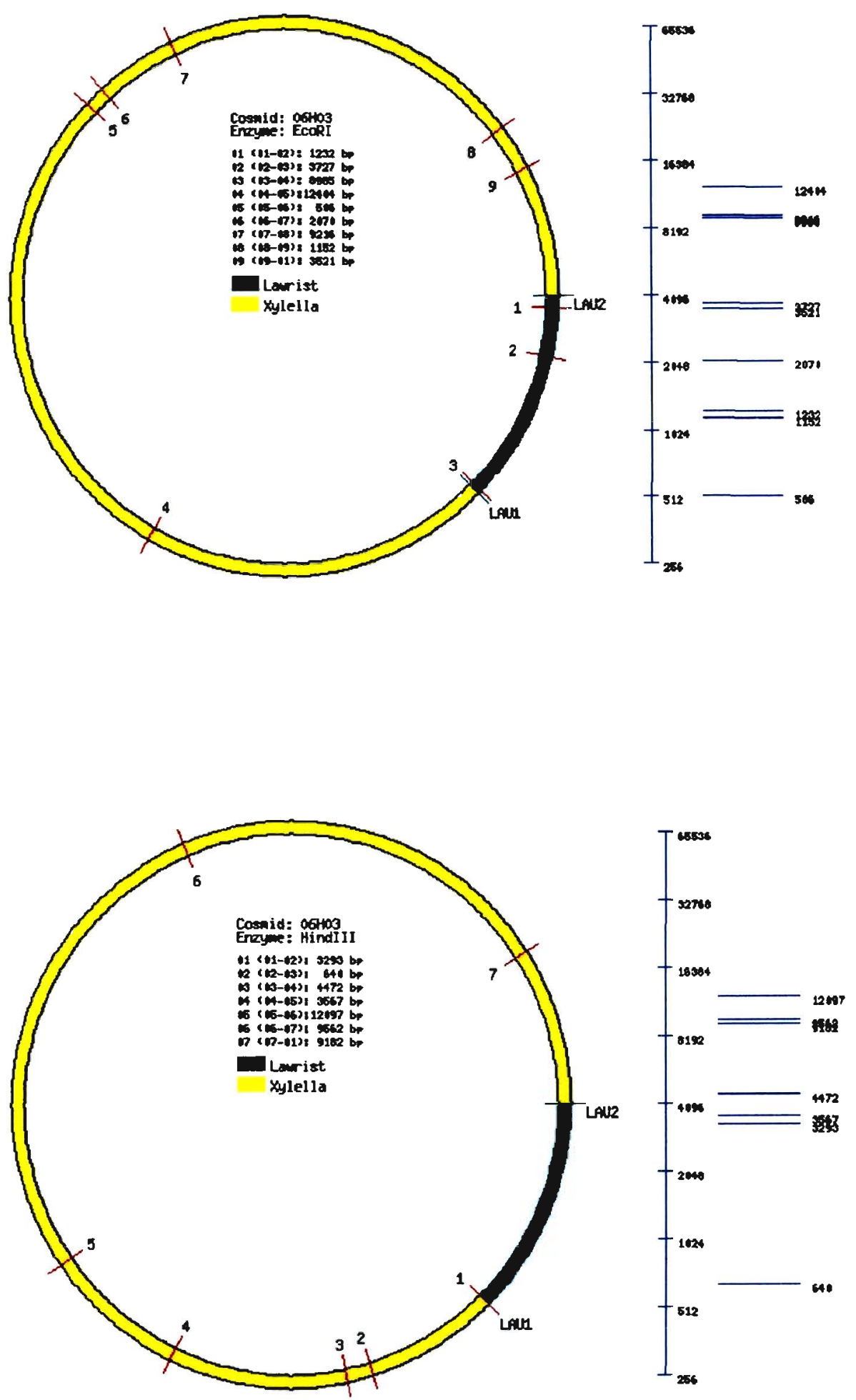


\section{H.4. Cosmídeo X0QV-07B03}

07B03/20-jan-1999

Finished.

14-dec-1998

Close to finished.

Declared in November. FAPESP notified on 27-nov-1998.

Created report.txt today, with new regions to be re-sequenced; these include low consensus q. missed previously (why?) and NCBS not analyzed previously.

- Preliminary certification report for cosmid 07B03

Date: Wed 20-Jan-1999

$39880-603+1=39278$ bp, 1024 reads.

EXPECTED ERROR RATE: 0.08 / $10000 \mathrm{bp}$

LOW CONSENSUS QUALITY (LCQ) REGIONS:

TOTAL: 0

HIGH QUALITY DISCREPANCIES (HQD):

$\begin{array}{ll}\text { X0QV-07B03-A018R } & 19428-19428(1) \\ \text { X0QV-07B03-N259R } & 39030-39033(4) \\ \text { X0QV-07B03-A072F } & 13989-13989(1) \\ \text { X0QV-07B03-A072F } & 13991-13993(3) \\ \text { X0QV-07B03-A072F } & 13995-13995(1) \\ \text { X0QV-07B03-N110R } & 11873-11875(3) \\ \text { X0QV-07B03-N156R } & 21411-21414(4) \\ \text { X0QV-07B03-N132R } & 20808-20808(1) \\ \text { X0QV-07B03-N132R } & 20809-20810(2) \\ \text { X0QV-07B03-N132R } & 20812-20812(1) \\ \text { X0QV-07B03-N151R } & 17683-17683(1)\end{array}$

All of these are close to unaligned regions. We asked S. Verjovski about this high incidence of HQDs, suggesting that they might be due to unrecognized vector. Here is his reply:

Date: Wed, 20 Jan 1999 13:25:24 -0200

From: Sergio Verjovski-Almeida <verjo@iq.usp.br>

Usamos sempre o velho pBluescript SK! [acho que ele quer dizer KS. JCS] Acho que se deve ao fato de que estas sequencias foram as primeiras que fizemos em marco de 1998 (!). Este era o primeiro cosmideo. Naquela epoca a gente tinha manchas muito grandes de dyeterminator livre nao incorporado, no inicio dos reads, o que dá erro de leitura. Alem disso, a gente deixava o base-caller do ABI pegar o inicio do read por conta propria. Ele sempre pega os scans muito no inicio demais, e a sequencia naquele lugar é péssima. Agora a gente sempre modifica o start-point do base-calling, na hora de fazer o extract da sequencia, no ABI, a partir da imagem do gel, e eliminamos os primeiros scans. Fica muito melhor o espacamento médio, e o base-calling, e não dá erros no inicio. Como teriamos que abrir um por um as imagens dos géis iniciais, e refazer o tracking e o extract, isto seria trabalho demais! 
Explanations accepted.

TOTAL: 0

POSITIONS NOT CONFIRMED ON BOTH STRANDS (NCBS):

TOTAL: 0

\section{ASSEMBLY WITH LAWRIST:}

This doesn't work because of the "adjacent cosmid reads" problem. In addition, I (JCS) had to manually edit the assembly (from check01) to change to n's all bases on reads to the left and to the right of the true ends. These were recognized thanks to lawrist masking of $7 \mathrm{~b} 3$ reads. The result is that the cosmid begins at base 603 and ends at base 39880 . New assembly is under check01/edit_dir and is called <usual stuff>.ace.1.

Note that some LCQs and NCBSs occur, but outside of the range given above.

CONCLUSION: Cosmid finished.

END OF ANALYSIS

- Digestão com enzimas de restrição (BamH I, EcoR I e Hind III)

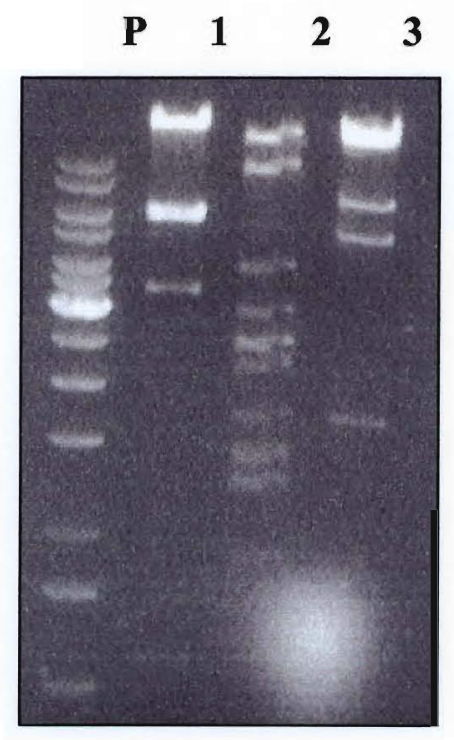

Figura 20: Eletroforese em gel de agarose 1.2\%. P: Padrão de tamanho molecular de $1 \mathrm{~Kb} ; 1,2$ e 3: Cosmídeo X0QV-07B03 digerido respectivamente com BamH I, EcoR I e Hind III. 


\section{H.5. Cosmídeo X0QV-08A03}

\section{- Cronograma}

08A03/Thu 04-Feb-1999

Finished

08A03/21-Jan-1999

08A03/Wed 03-Feb-1999

Close to Finished

Close to finished.

FAPESP not yet notified.

Sat 16-Jan-1999

One-contig

- Preliminary certification report for cosmid $08 \mathrm{~A} 03$

Date: Thu 04-Feb-1999

READ COMPOSITION: 1114 reads;

EQ-07B01 : 34 reads

EZ-07C01 : 14 reads

JJ-09E09 : 206 reads

QR-07H03 : 11 reads

QR-07H04 : 15 reads

QV-08A03 : 452 reads

UT-07A07 : 324 reads

plasmid : 58 reads

Contig size: $39420 \mathrm{bp}$

Insert size: $38066 \mathrm{bp}$ (excludes lawrist and/or cosmid extensions)

LAWRIST LOCATIONS:

Left : first base after LAU1 $=651$

Right : last base before LAU2 $=38716$

EXPECTED ERROR RATE: $0.01 / 10000 \mathrm{bp}$

LOW CONSENSUS QUALITY (LCQ) REGIONS:

TOTAL: 0

HIGH QUALITY DISCREPANCIES (HQD):

TOTAL: 0

POSITIONS NOT CONFIRMED ON BOTH STRANDS (NCBS):

TOTAL: 0

CONCLUSION: Cosmid FINISHED

END OF ANALYSIS 
- Digestão com enzimas de restrição (BamH I, EcoR I e Hind III) e digestão eletrônica do cosmídeo X0QV-08A03

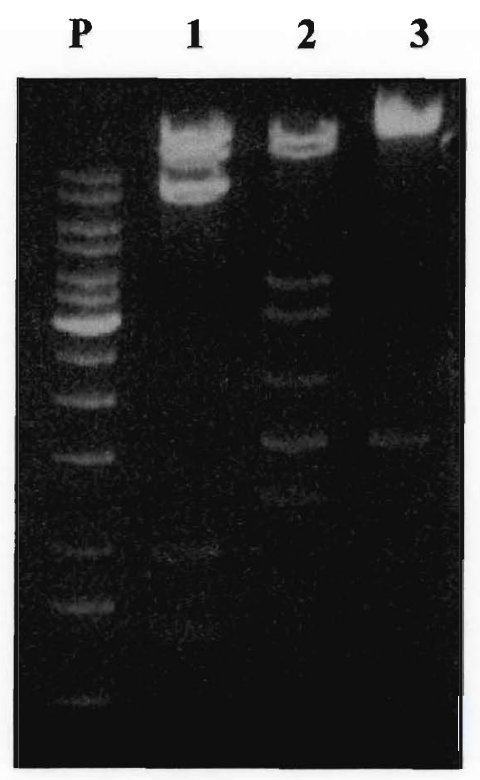

Figura 21: Eletroforese em gel de agarose 1.2\%. P: Padrão de tamanho molecular de $1 \mathrm{~Kb}$; 1, 2 e 3: Cosmídeo X0QV-08A03 digerido respectivamente com BamH I, EcoR I e Hind III
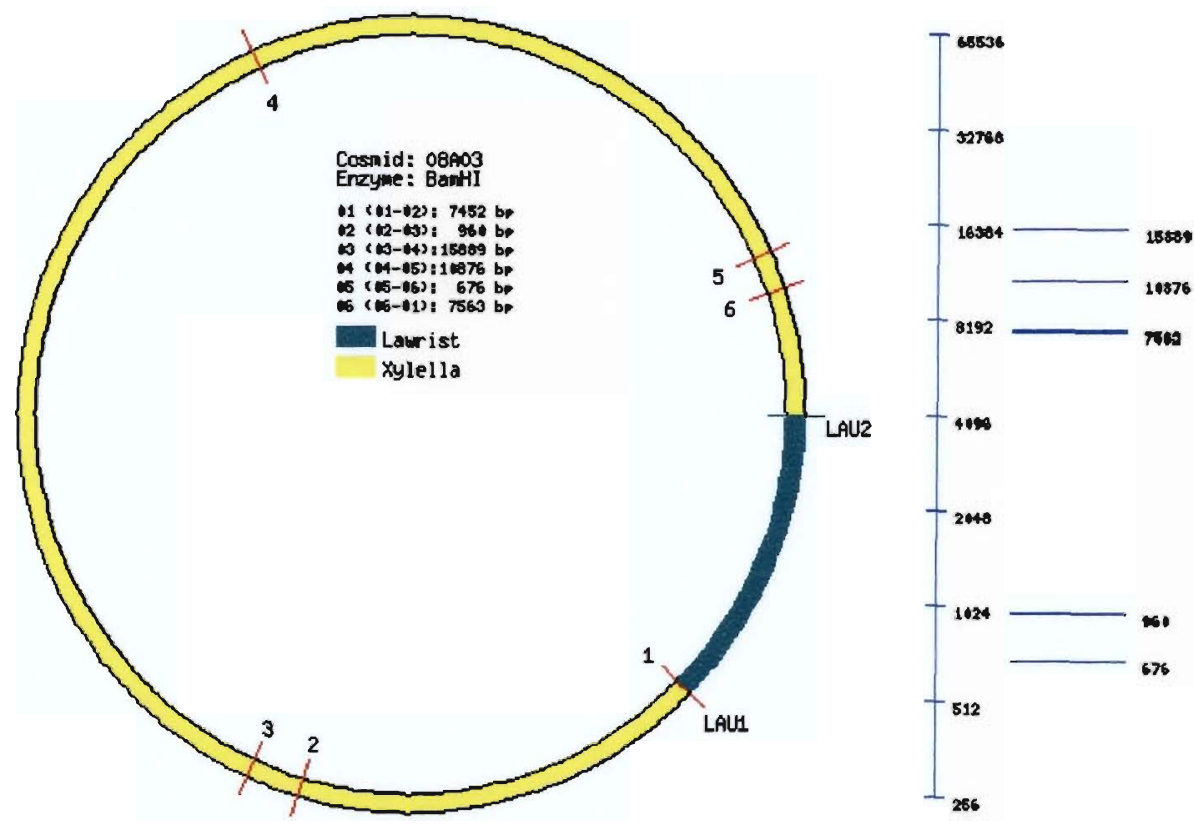

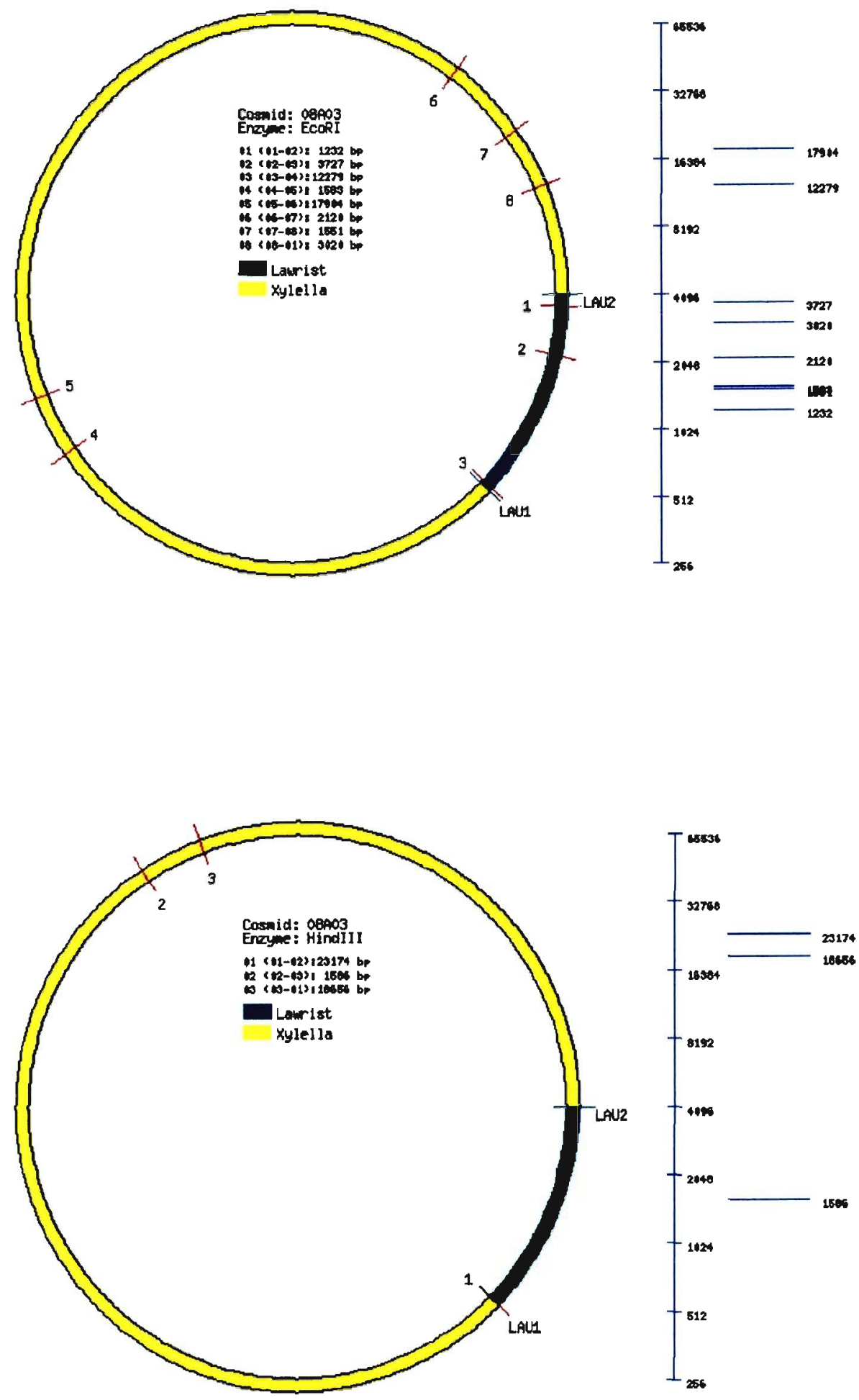


\section{H.6. Cosmídeo X0QV-10F11}

\section{- Cronograma}

10F11/Wed 25-Aug-1999

Submitted

Finished

10F11/Wed 25-Aug-1999

10F11/19-Aug-1999

Submitted

10F11/Wed 25-Aug-1999

Submitted

10F11/Mon 23-Aug-1999

One-contig

10F 11/Thu 05-Aug-1999

Submitted

10F11/Tue 20-Jul-1999

Submitted

Submitted

10F11/Mon 23-Aug-1999

10F11/Thu 01-Jul-1999

Submitted

- Preliminary certification report for cosmid $08 \mathrm{~A} 03$

Date: Wed 25-Aug-1999

READ COMPOSITION: 1181 reads;

BG-01G04 : 132 reads

IU-01G04 : 237 reads

MR-07A12 : 15 reads

PM-07B08 : 310 reads

QV-10F11 : 343 reads

plasmid : 144 reads

Contig size: 35743 bp

Insert size: 34418 bp (excludes gap extensions)

EXTREMES LOCATIONS:

Left : first base after LAU2 (CACTATAGAATACTAGGATC) $=555$

Right : last base before LOSTLAU (GATCCTAGTATTCTATAGTGTCA) $=34972$

EXPECTED ERROR RATE: $0.00 / 10000 \mathrm{bp}$

LOW CONSENSUS QUALITY (LCQ) REGIONS:

TOTAL: 0

HIGH QUALITY DISCREPANCIES (HQD):

TOTAL: 0

POSITIONS NOT CONFIRMED ON BOTH STRANDS (NCBS):

TOTAL: 0

CONCLUSION: Gap FINISHED

END OF ANALYSIS 


\section{H.7. Cosmídeo X0QV-20F11}

\section{- Cronograma}

20F11/Wed 25-Aug-1999

Finished

20F11/Wed 21-Jul-1999

20F11/Thu 05-Aug-1999

Submitted

One-contig

- Preliminary certification report for cosmid 20F11

Date: Wed 25-Aug-1999

READ COMPOSITION: 138 reads;

IL-10F11 : 1 read

QV-10F11: 38 reads

RC-07A08 : 94 reads

plasmid : 5 reads

Contig size: 5809 bp

Insert size: 4437 bp (excludes gap extensions)

EXTREMES LOCATIONS:

Left : first base after LAU1 (TAGGGAGACCCAAGCTTAGGATC) $=490$

Right : last base before LOSTLAU (GATCCGACAGGTTACGGGGCGGC) $=4926$

EXPECTED ERROR RATE: $0.00 / 10000 \mathrm{bp}$

LOW CONSENSUS QUALITY (LCQ) REGIONS:

TOTAL: 0

HIGH QUALITY DISCREPANCIES (HQD):

TOTAL: 0

POSITIONS NOT CONFIRMED ON BOTH STRANDS (NCBS):

TOTAL: 0

CONCLUSION: Gap FINISHED

END OF ANALYSIS 


\section{H.8. Cosmídeo X0QV-11B08}

\section{- Cronograma}

11B08/Thu 11-Feb-1999

11B08/Thu 11-Feb-1999

Finished

Close to Finished

11B08/Thu 11-Feb-1999

11B08/08-jan-1999

Close to Finished

One-contig

- Preliminary certification report for cosmid 20F11

Date: Thu 11-Feb-1999

READ COMPOSITION: 1160 reads;

IC-07F02 : 184 reads

II-09C12 : 73 reads

IL-09C12: 1 read

QV-07B03 : 1 read

QV-11B08 : 742 reads

UI-07A04 : 58 reads

plasmid : 101 reads

Contig size: $39994 \mathrm{bp}$

Insert size: 39464 bp (excludes lawrist and/or cosmid extensions)

LAWRIST LOCATIONS:

Left : first base after LAU1 $=531$

Right : last base before LAU2 $=39994$

EXPECTED ERROR RATE: 0.00 / 10000 bp

LOW CONSENSUS QUALITY (LCQ) REGIONS:

TOTAL: 0

HIGH QUALITY DISCREPANCIES (HQD):

TOTAL: 0

POSITIONS NOT CONFIRMED ON BOTH STRANDS (NCBS):

TOTAL: 0

CONCLUSION: Cosmid FINISHED

END OF ANALYSIS 
- Digestão com enzimas de restrição (BamH I, EcoR I e Hind III) e digestão eletrônica do cosmídeo X0QV-08A03

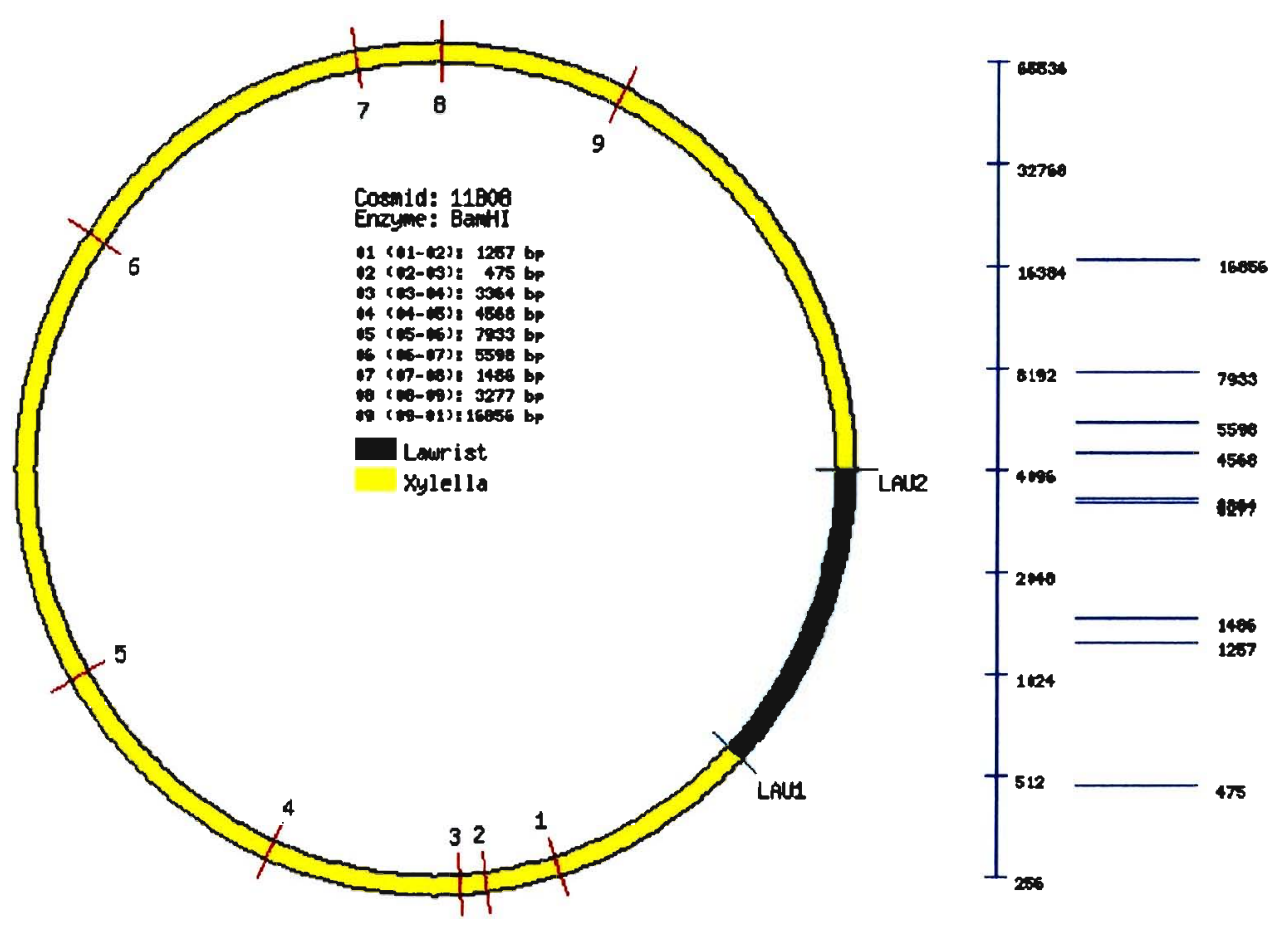



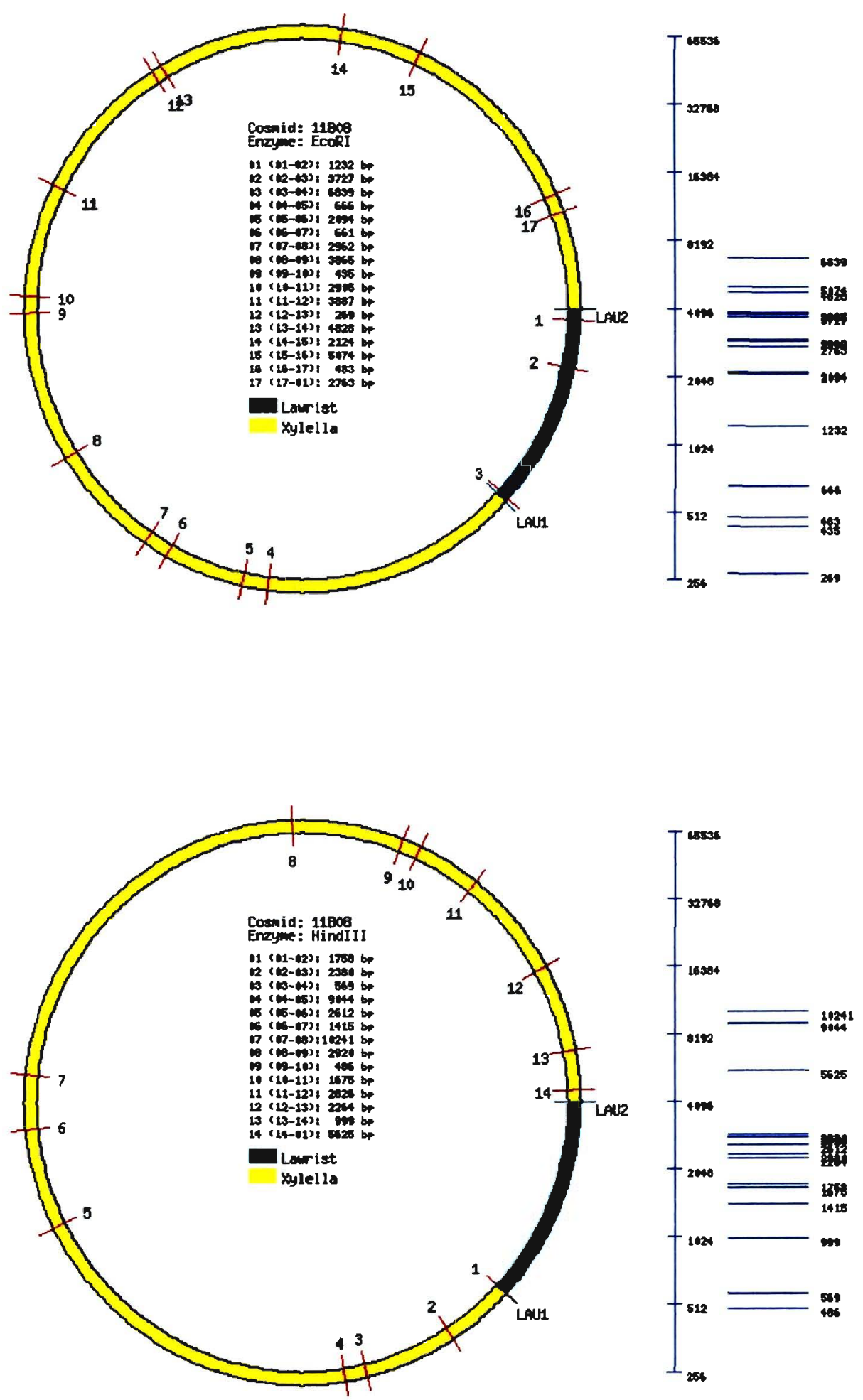


\section{Clones "shotgun" - GFSs ("gap filling sequences).}

\section{I.1. GFS X0QV-00J18 (X0QV0010G03)}

\section{- $\underline{\text { Cronograma }}$}

00J18/Tue 23-Nov-1999

Finished

00J18/Thu 18-Nov-1999

Close to Finished
00J18/Wed 17-Nov-1999

One-contig

00J18/Tue 16-Nov-1999

Submitted

- Preliminary certification report for gap 00J18

Date: Tue 23-Nov-1999

READ COMPOSITION: 97 reads;

QV-00J18 : 45 reads

plasmid : 52 reads

Contig size: $3731 \mathrm{bp}$

Insert size: 2805 bp (excludes gap extensions)

EXTREMES LOCATIONS:

Left : first base after X0QV0010G03F (TACTGGTAAGCGAGGAAC) $=515$

Right : last base before X0QV0010G03R (GAAGATGTTGACATTGGA) = 3319

EXPECTED ERROR RATE: $0.01 / 10000$ bp

LOW CONSENSUS QUALITY (LCQ) REGIONS:

TOTAL: 0

HIGH QUALITY DISCREPANCIES (HQD):

TOTAL: 0

POSITIONS NOT CONFIRMED ON BOTH STRANDS (NCBS):

TOTAL: 0

CONCLUSION: Gap FINISHED

E. Coli contamination:

None detected.

END OF ANALYSIS 


\section{I.2. GFS X0QV-00J19 (X0QV1067G10).}

- $\underline{\text { Cronograma }}$

00J19/Wed 01-Dec-1999

00J19/Thu 25-Nov-1999

Finished

Close to Finished

- Preliminary certification report for gap 00J19

Date: Wed 01-Dec-1999

READ COMPOSITION: 52 reads;

QV-00J19 : 27 reads

plasmid : 25 reads

Contig size: $4189 \mathrm{bp}$

Insert size: $2601 \mathrm{bp}$ (excludes gap extensions)

EXTREMES LOCATIONS:

Left : first base after X0QV1067G10F (AGTCCAACGTGTGATCGT) $=623$

Right : last base before X0QV1067G10R (TGTTGGACCCCAAACCAA) $=3223$

EXPECTED ERROR RATE: $0.00 / 10000$ bp

LOW CONSENSUS QUALITY (LCQ) REGIONS:

TOTAL: 0

HIGH QUALITY DISCREPANCIES (HQD):

TOTAL: 0

POSITIONS NOT CONFIRMED ON BOTH STRANDS (NCBS):

TOTAL: 0

CONCLUSION: Gap FINISHED

E. Coli contamination:

None detected.

END OF ANALYSIS 


\section{I.3. GFS X0QV-00J34 (X0QV1034E07).}

- Cronograma

00J34/Thu 09-Dec-1999

00J34/Thu 09-Dec-1999

Finished

Close to Finished

- Preliminary certification report for gap 00J34

Date: Thu 09-Dec-1999

READ COMPOSITION: 91 reads;

QV-00J34 : 23 reads

plasmid : 68 reads

Contig size: $3381 \mathrm{bp}$

Insert size: 2169 bp (excludes gap extensions)

EXTREMES LOCATIONS:

Left : first base after X0QV1034E07F (CACCAGGTGATGTCGTGG) $=491$

Right : last base before X0QV1034E07R (CATCTGGCGCTCAATGTG) $=2659$

EXPECTED ERROR RATE: $0.00 / 10000 \mathrm{bp}$

LOW CONSENSUS QUALITY (LCQ) REGIONS:

TOTAL: 0

HIGH QUALITY DISCREPANCIES (HQD):

TOTAL: 0

POSITIONS NOT CONFIRMED ON BOTH STRANDS (NCBS):

TOTAL: 0

CONCLUSION: Gap FINISHED

E. Coli contamination:

None detected.

END OF ANALYSIS 


\section{I.4 GFS X0QV-00J53 (X0QV1034H11).}

\section{- Cronograma}

00J53/Tue 07-Dec-1999

Finished

- Preliminary certification report for gap 00J53

Date: Tue 07-Dec-1999

READ COMPOSITION: 61 reads;

QV-00J53 : 32 reads

plasmid : 29 reads

Contig size: 3554 bp

Insert size: 2710 bp (excludes gap extensions)

EXTREMES LOCATIONS:

Left : first base after X0QV1034H11R (ATTCCGAAGAAGTCACCA) $=422$

Right : last base before X0QV1034H11F (AAACAGCCCCGTTAATCG) = 3131

EXPECTED ERROR RATE: $0.00 / 10000$ bp

LOW CONSENSUS QUALITY (LCQ) REGIONS:

TOTAL: 0

HIGH QUALITY DISCREPANCIES (HQD):

TOTAL: 0

POSITIONS NOT CONFIRMED ON BOTH STRANDS (NCBS):

TOTAL: 0

CONCLUSION: Gap FINISHED

E. Coli contamination:

None detected.

END OF ANALYSIS 


\section{I.5. GFS X0QV-00J67 (X0QV0010C05).}

\section{- $\underline{\text { Cronograma }}$}

00J67/Thu 06-Jan-2000

00J67/Tue 21-Dec-1999

Finished

One-contig

00J67/Wed 22-Dec-1999

00J67/Mon 20-Dec-1999

Close to Finished

One-contig

- Preliminary certification report for gap 00J67

Date: Thu 06-Jan-2000

READ COMPOSITION: 81 reads;

QV-00J67 : 59 reads

plasmid : 22 reads

Contig size: 2042 bp

Insert size: 1472 bp (excludes gap extensions)

EXTREME LOCATIONS:

Left : first base after X0QV0010C05F (TTAGTAGTGTGATCGCCG) $=553$

Right : last base before X0QV0010C05R (CTTCTTTGTCGAGAAGAA) $=2024$

EXPECTED ERROR RATE: $0.00 / 10000 \mathrm{bp}$

LOW CONSENSUS QUALITY (LCQ) REGIONS:

TOTAL: 0

HIGH QUALITY DISCREPANCIES (HQD):

TOTAL: 0

POSITIONS NOT CONFIRMED ON BOTH STRANDS (NCBS):

TOTAL: 0

CONCLUSION: Gap FINISHED

E. Coli contamination:

None detected.

END OF ANALYSIS 


\section{I.6. GFS X0QV-07J24 (X0QV0724G04).}

- Cronograma

07J24/Tue 21-Dec-1999

Finished

One-contig

07J24/Wed 01-Dec-1999

07J24/Mon 29-Nov-1999

Submitted

- Preliminary certification report for gap 07J24

Date: Tue 21-Dec-1999

READ COMPOSITION: 37 reads;

QV-07J24: $1 \mathrm{read}$

plasmid : 36 reads

Contig size: $2811 \mathrm{bp}$

Insert size: 1989 bp (excludes gap extensions)

EXTREME LOCATIONS:

Left : first base after X0QV0724G04F (CAATGGAAATGCGCCGCT) $=805$

Right : last base before X0QV0724G04R (CGTCGCGCAGCATCAGCG) = 2793

EXPECTED ERROR RATE: $0.00 / 10000 \mathrm{bp}$

LOW CONSENSUS QUALITY (LCQ) REGIONS:

TOTAL: 0

HIGH QUALITY DISCREPANCIES (HQD):

TOTAL: 0

POSITIONS NOT CONFIRMED ON BOTH STRANDS (NCBS):

TOTAL: 0

CONCLUSION: Gap FINISHED

E. Coli contamination:

None detected.

END OF ANALYSIS 


\section{I.7. GFS X0QV-10J64 (X0QV1064D09).}

\section{- Cronograma}

10J64/Tue 21-Dec-1999

Close to Finished

Finished (manually)

10J64/Tue 21-Dec-1999

10J64/Tue 21-Dec-1999

Close to Finished

10J64/Tue 21-Dec-1999

Close to Finished

10J64/Tue 07-Dec-1999

One-contig

- Preliminary certification report for gap 10J64

Date: Tue 21-Dec-1999

READ COMPOSITION: 33 reads;

QV-10J64 : 4 reads

plasmid : 29 reads

Contig size: $3082 \mathrm{bp}$

Insert size: 2097 bp (excludes gap extensions)

EXTREME LOCATIONS:

Left : first base after X0QV1064D09R (AGACGCTGCTGCTGGGCC) $=323$

Right : last base before X0QV1064D09F (CCCTGCTGCGCCCCGTCT) $=2419$

EXPECTED ERROR RATE: $0.00 / 10000$ bp

LOW CONSENSUS QUALITY (LCQ) REGIONS:

TOTAL: 0

HIGH QUALITY DISCREPANCIES (HQD):

TOTAL: 0

POSITIONS NOT CONFIRMED ON BOTH STRANDS (NCBS):

1423-1423 (1): ABI base call confirms the position.

TOTAL: 0

CONCLUSION: Gap Finished

E. Coli contamination:

None detected.

END OF ANALYSIS 


\section{J. Classification of E.coli genes products (Monica Riley)}

I Intermediary metabolism
A Degradation
B Central Intermediary metabolism
C Fermentation
D ATP-proton motive force interconversion
E Broad regulatory functions

II Biosynthesis of small molecules

A Amino acids

1. Glutamine family/nitrogen assimilation

2. Aspartate family, pyruvate family

3. Glycine-serine family/ sufer metabolism

4. Aromatic amino acid family

5. Histidine

B Nucleotides

1. Purine ribonucleotides

2. Pyrimidine ribonucleotides

3. 2'Deoxyribonucleoties

4. Salvage and interconversions

C Sugar and sugar nucleotides

D Cofactors, prosthetic groups, electron carriers

1. Biotin

2. Folic acid

3. Lipoate

4. Molybdopterin

5. Pantothenate

6. Pyridoxine

7. Pyridine nucleotides

8. Thiamine

9. Riboflavine

10. Thioredoxin, glutaredoxin and glutathione 
11. Menaquinone and ubiquinones

12. Heme and porphyrins

E Fatty acids and lipids

F Polyamines

III Macromolecule metabolism

A Synthesis and modification

1. Ribosomal and "stable" RNAs

2. Ribosomal proteins and their modification

3. Ribosomes and their maturation and modification

4. TRNAs, aminoacyl-tRNA synthetases and their modification

5. RNA synthesis, modification and DNA transcription

6. Basic proteins

7. DNA replication restriction/modification recombination and repair

8. Proteins (translation and modification)

9. Polysaccharides (cytoplasmic)

B Degradation of macromolecules

1. RNA

2. DNA

3. Proteins

IV Cell Structure
A Membrane components
B Murein sacculus
C Surface polysaccharides and antigens
D Surface structures

V Cellular process
A Transport/binding proteins
B Cell division
C Chemotaxis and mobility
D Protein secretion
E Osmotic adaptation 
VI Other functions
A Cryptic genes
B Phage-related functions and prophages
C Colicin-related funtions
D Plasmid-related functions
E Drug/ analog sensitivity
F Radiation sensitivity
G DNA sites
$\mathrm{H}$ Adaptation to atypical conditions 


\section{K. Table for Xylella fastidiosa genome}

I. Intermediary metabolism (251)

A. Degradation (33)

1.Degradation of polysaccharides (0)

2. Degradation of small molecules (33)

B. Central intermediary metabolism (58)

1. Amino sugars (4)

2. Entner-Douderoff (2)

3. Gluconeogenesis (7)

4. Glyoxylate bypass $(0)$

5. Miscellaneous glucose metabolism (0)

6. Non-oxidative branch, pentose pathway (3)

7. Nucleotide hydrolysis $(0)$

8. Nucleotide interconversions (2)

9. Phosphorus compounds (4)

10. Pool, multipurpose conversions (18)

11. Sugar-nucleotide biosynthesis, conversions (12)

12. Sulfur metabolism (6)

C. Energy metabolism, carbon (92)

1. Aerobic respiration (17)

2. Anaerobic respiration and fermentation (6)

3. Electron transport (29)

4. Glycolysis (9)

5. Oxidative branch, pentose pathway (2)

6 .Pyruvate dehydrogenase (4)

7. TCA cycle (19)

8. ATP-proton motive force interconversion (8)

D. Regulatory functions (77)

II.Biosynthesis of small molecules (226)

A. Amino acids biosynthesis (83)

1. Glutamate family|nitrogen assimilation (16) 
2. Aspartate family, pyruvate family (30)

3. Glycine-serine family|sulfur metabolism (6)

4. Aromatic amino acid family (23)

5. Histidine (8)

B. Nucleotides biosynthesis (41)

1. Purine ribonucleotides (19)

2. Pyrimidine ribonucleotides (8)

3. 2'-Deoxyribonucleotides (6)

4. Salvage of nucleosides and nucleotides (8)

C. Sugars and sugar nucleotides biosynthesis (2)

D. Cofactors, prosthetic groups, carriers biosynthesis (79)

1. Biotin (8)

2. Folic acid (8)

3. Lipoate (2)

4. Molybdopterin (2)

5. Pantothenate (3)

6. Pyridoxine (3)

7. Pyridine nucleotides (5)

8. Thiamin (8)

9. Riboflavin (7)

10. Thioredoxin, glutaredoxin, glutathione (8)

11. Menaquinone, ubiquinone (8)

12. Heme, porphyrin (12)

13. Biotin carboxyl carrier protein (BCCP) (0)

14. Cobalamin (1)

15. Enterochelin (0)

16. Biopterin (3)

17. Others (1)

E. Fatty acid and phosphatidic acid biosynthesis (22)

F. Polyamines biosynthesis (3)

III.Macromolecule metabolism (392)

A. DNA metabolism (111)

1. Replication (31) 
2. Structural DNA binding proteins (10)

3. Recombination (18)

4. Repair (37)

5. Restriction, modification (23)

B. RNA metabolism (183)

1. Ribosomal and stable RNAs (56)

2. Ribosomal proteins (54)

3. Ribosomes - maturation and modification (13)

4. Aminoacyl tRNA synthetases, tRNA modification (35)

5. RNA synthesis, modification, DNA transcription (16)

6. RNA degradation (8)

C. Protein metabolism (85)

1. Translation and modification (40)

2. Chaperones (11)

3. Protein degradation (34)

D. Other macromolecules metabolism (17)

1. Polysaccharides (15)

2. Phospholipids (2)

IV.Cell structure (145)

A. Membrane components (55)

1. Inner membrane (25)

2. Outer membrane constituents (23)

B. Murein sacculus, peptidoglycan (26)

C. Surface polysaccharides, lipopolysaccharides, and antigens (30)

D. Surface structures (34)

V.Cellular processes (167)

A. Transport (141)

1. Amino acids, amines (7)

2. Anions (11)

3. Carbohydrates, organic acids, alcohols (17)

4. Cations (24)

5. Nucleosides, purines, pyrimidines $(0)$ 

6. Protein, peptide secretion (29)
7. Other (53)
B. Cell division (25)
C. Chemotaxis and mobility (3)
D. Osmotic adaptation (0)
E. Cell killing (0)

VI.Mobile genetic elements (144)
A. Phage-related functions and prophages (83)
B. Plasmid-related functions (52)
C. Transposon- and intron-related functions (9)

VII.Pathogenicity, virulence, and adaptation (147)
A. Avirulence (0)
B. Hypersensitive response and pathogenicity (1)
C. Toxin production and detoxification (70)
D. Host cell wall degradation (6)
E. Exopolysaccharides (9)
F. Surface proteins (7)
G. Adaptation, atypical conditions (28)
H. Other (29)

VIII. Hypothetical (1534)
A. Conserved hypothetical proteins (318)
B. Hypothetical proteins (includes no hits/only low score hits) (1216)

IX. ORFs with undefined category (24) 


\section{Protocolos}

L.1. Protocolo para Miniprep (adaptado pelo Prof.Dr. Marcelo Bento Soares)

1. Crescer as bactérias em $2 \mathrm{~mL}$ de Terrific Buffer (Maniatis A-2) contendo antibiótico adequado, overnight a $37^{\circ} \mathrm{C}, 300 \mathrm{rpm}$. Posicionar os tubos de maneira inclinada para garantir uma boa aeração do meio.

2. Transferir o conteúdo dos tubos para eppendorfs $(1,5 \mathrm{~mL})$ identificados. Centrifugar a $14000 \mathrm{rpm}$ por 3 minutos.

3. Aspirar o sobrenadante (vácuo) tomando o cuidado de retirar o máximo possível de meio de cultura.

4. Adicionar $100 \mu \mathrm{L}$ da solução I contendo RNAse. Ressuspender o pellet com o auxílio da pipeta ou do vortex. O pellet deverá estar totalmente ressuspenso.

5. Adicionar $200 \mu \mathrm{L}$ da solução II (Lise). Misturar cuidadosamente por inversão por 5 minutos. Deixar parado por 5 minutos na bancada. O passo 6 deve ser efetuado imediatamente após este passo.

6. Adicionar $200 \mu \mathrm{L}$ da solução III (Neutralização). Misturar por inversão por 3 minutos. Manter em gelo $\left(4^{\circ} \mathrm{C}\right)$ por 20 minutos.

7. Centrifugar a $14000 \mathrm{rpm}$ por 20 minutos.

8. Preparar novos tubos eppendorfs $(1,5 \mathrm{~mL})$ devidamente identificados. Após a centrifugação, coletar $400 \mu \mathrm{L}$ do sobrenadante transferindo-os para os novos tubos. Adicionar $300 \mu \mathrm{L}$ de Isopropanol. Tampar e misturar por inversão (4X).

9. Centrifugar a $14000 \mathrm{rpm}$ por 20 minutos. Aspirar o sobrenadante com o cuidados de não aspirar o pellet.

10. Lavar com $500 \mu \mathrm{L}$ de Etanol $70 \%$. Centrifugar a $14000 \mathrm{rpm}$ por 20 minutos.

11. Aspirar o sobrenadante e secar o pellet (a $80^{\circ} \mathrm{C}$ em vácuo, por 5 minutos).

12. Ressuspender o pellet em $20 \mu \mathrm{L}$ de Tris $10 \mathrm{mM}, \mathrm{pH} 8,0$ (pode se usar o vortex).

13. Aplicar $1,0 \mu \mathrm{L}$ das amostras em gel de agarose $(1,2 \%)$ para quantificá-las. 
a) Solução I

Dextrose

Tris $\mathrm{HCl} \mathrm{pH} 8,0$

EDTA

Ribonuclease A

b) Solução II

SDS

$\mathrm{NaOH}$

c) Solução III

Acetato de potássio
$0,5 \mathrm{M}$

$25 \mathrm{mM}$

7,5 mM

$0,15 \mathrm{mg} / \mathrm{mL}$

$1 \%$

$0,2 \mathrm{~N}$

$1,3 \mathrm{M}$ ph 4,8 


\section{L.2. Preparação de células eletrocompetentes}

1) Repicar uma colônia isolada em $5 \mathrm{~mL}$ de meio LB (Maniats) contendo o antibiótico adequado (no caso das cepas Top10 ou XL1-blue, utilizou-se $30 \mu \mathrm{g} / \mathrm{mL}$ de Tetraciclina). Crescer este pré-inóculo overnight à $37^{\circ} \mathrm{C}$ e $250 \mathrm{rpm}$.

2) Transferir $1 / 10(500 \mu \mathrm{L})$ deste pré-inóculo em frasco erlenmeyer contendo $500 \mathrm{~mL}$ de meio LB contendo antibiótico adequado (novamente usado $30 \mu \mathrm{g} / \mathrm{mL}$ de Tetraciclina). A cultura deve ser crescida até alcançar uma OD600 =0,6-0,8.

3) As células devem sempre ser trabalhadas em gelo.

4) Transferir a cultura crescida para frascos de $250 \mathrm{~mL}$. Centrifugar à 3000 rpm, $4^{\circ} \mathrm{C}$ por 10 minutos.

Para cada $250 \mathrm{~mL}$ iniciais de cultura:

5) Ressuspender o pellet em $50 \mathrm{~mL}$ de água milliQ autoclavada e gelada. Centrifugar à $3000 \mathrm{rpm}, 4^{\circ} \mathrm{C}$ por 10 minutos.

6) Ressuspender o pellet em $25 \mathrm{~mL}$ de água milliQ autoclavada e gelada. Transferir para tubos de $40 \mathrm{~mL}$. Centrifugar à $3000 \mathrm{rpm}, 4^{\circ} \mathrm{C}$ por 10 minutos.

7) Ressuspender o pellet em $2 \mathrm{~mL}$ de $10 \%$ glicerol estéril gelado. Centrifugar à $3000 \mathrm{rpm}, 4^{\circ} \mathrm{C}$ por 10 minutos.

8) Ressuspender o pellet em $200 \mu \mathrm{L}$ de $10 \%$ glicerol estéril gelado.

9) Aliquotar $40 \mu \mathrm{L}$ em tubos eppendorfs $1,5 \mathrm{~mL}$ previamente gelados e imediatamente colocá-los em gelo seco. Estocar as células em $-80^{\circ} \mathrm{C}$. 


\section{L.3. Preparação de células quimio-competentes}

1) Repicar uma colônia de células em $10 \mathrm{~mL}$ de meio LB (Maniats) contendo antibiótico adequado (no caso das cepas Top10 ou XL1-blue, utilizou-se $50 \mu \mathrm{g} / \mathrm{mL}$ de Tetraciclina). Crescer as bactérias sob agitação $(250 \mathrm{rpm})$ durante 8 horas à $37^{\circ} \mathrm{C}$.

2) Diluir este pré inóculo $1 / 10 \mathrm{em} 5 \mathrm{~mL}$ de meio LB contendo antibiótico adequado $(50 \mu \mathrm{g} / \mathrm{mL}$ de Tetraciclina) e crescer overnight sob agitação de $250 \mathrm{rpm}$ à $37^{\circ} \mathrm{C}$.

3) Diluir esta cultura $1 / 100 \mathrm{em} 500 \mathrm{~mL}$ de meio LB contendo antibiótico adequado $\left(50 \mu \mathrm{g} / \mathrm{mL}\right.$ de Tetraciclina) e crescer até $\mathrm{OD}_{600}=0,3$ sob agitação de $250 \mathrm{rpm}$ à $37^{\circ} \mathrm{C}$.

4) Transferir para tubos de centrifuga $(250 \mathrm{~mL})$, incubar em gelo por 5 minutos e centrifugar pro 10 minutos à $3000 \mathrm{~g} \mathrm{e} 4^{\circ} \mathrm{C}$.

5) Ressuspender o pellet (bem seco) em $1 / 5$ do volume original (100mL) com tampão cálcio/glicerol pH 6,4 gelado

6) Repetir os passos 4 e 5

7) Incubar em gelo por 30 minutos

8) Centrifugar por 5 minutos à $3000 \mathrm{rpm} \mathrm{e} 4^{\circ} \mathrm{C}$

9) Ressuspender cuidadosamente e em gelo, o pellet em 1/40 do volume original (12,5mL) com tampão cálcio/glicerol pH 6,4 gelado.

10) Imediatamente dividir em alíquotas de $50 \mu \mathrm{L}$ em eppendorfs $1,5 \mathrm{~mL}$ já previamente esfriados em gelo seco.

11) Estocar à $-80^{\circ} \mathrm{C}$.

Tampão Cálcio/Glicerol pH 6,4:

$60 \mathrm{mM} \mathrm{CaCl}_{2}$

$10 \mathrm{mM}$ PIPES pH 6,4

$15 \%$ glicerol

O volume final é completado com água milliQ autoclavada e a solução é esterelizada por filtração ou autoclave. 


\section{L.4. Boiling 96 well plasmid m ini prep}

1) Selecionar as colônias brancas repicadas em placa "elisa" (fundo redondo) contendo $100 \mu \mathrm{L}$ de meio TB (Maniats) e $100 \mu \mathrm{g} / \mathrm{mL}$ de antibiótico adequado (no caso dos vetores utilizados em nosso laboratório : puC18 e pbSSK, foi utilizado o antibiótico Ampicilina) crescidas sem agitação durante $16 \mathrm{hs}$ à $37^{\circ} \mathrm{C}$. Adicionar $100 \mu \mathrm{L}$ de glicerol $30 \%$ e este "estoque" foi estocado à $-80^{\circ} \mathrm{C}$.

Para o procedimento da boiling prep deve-se crescer as células por 24 horas à $37^{\circ} \mathrm{C}, 300 \mathrm{rpm}$ em $1 \mathrm{~mL}$ de meio TB contendo $100 \mu \mathrm{g} / \mathrm{mL}$ de antibiótico adequado em “deep well plates". As células são repicadas da placa estoque com o auxílio de um replicador "hedgehog", transferindo o inóculo 2 vezes.

2) Coletar as células por 8 minutos à 3000rpm. Chacoalhar firme o sobrenadante sobre uma pia e deixar drenando sobre papel absorvente por 5 minutos. Adicionar a cada poço $25 \mu \mathrm{L}$ de água milliQ estéril e vortexar bem para a ressuspensão completa das células. Adicionar a cada poço $70 \mu \mathrm{L}$ de MWSTET/TWEEN. Misturar bem com vortex por 1 minuto e manter a placa por 5 minutos a temperatura ambiente.

3) Colocar a placa em microondas de prato rotativo em disposição marcada e acionar até que ocorra a fervura no interior dos poços (bobe espuma no "well") tomando o cuidado para que não ocorra a mistura de amostras. Após a fervura inverter a posição da placa sobre a bandeja do microondas e repetir a operação. Repetir uma terceira vez invertendo novamente. Seja rápido entre estas interrupções e ao dar o pulso de aquecimento.

4) Adicionar $300 \mu \mathrm{L}$ de água milliQ autoclavada, vortexar por 15 segundos e manter em gelo por 10 minutos. Centrifugar a $6000 \mathrm{rpm}$ por 20 minutos (ou 40 $\mathrm{min} / 2900 \mathrm{rpm})$. Coletar $50 \mu \mathrm{L}$ do sobrenadante evitando recolher o precipitado. Manter esta placa estoque conservada a $-20^{\circ} \mathrm{C}$ até o uso para o sequenciamento e posteriormente estocá-la a $-80^{\circ} \mathrm{C}$.

5) Avaliar as amostras ( $5 \mu \mathrm{L} /$ amostra) em gel de agarose $1,2 \%$.

6) Utilizar de $2-4 \mu \mathrm{L}$ (400ng), dependendo da concentração do DNA, para cycle sequencing com o kit Big Dye terminator.

STET/TWEEN (conservar em geladeira) 
$5,0 \mathrm{~mL}$ de Tween 20

2,0 $\mathrm{mL}$ de $\mathrm{NaCl} 5 \mathrm{M}$

$1,6 \mathrm{~mL}$ de Tris- $\mathrm{Cl} 10 \mathrm{mM} \mathrm{pH8,0}$

$0,22 \mathrm{~mL}$ de EDTA $0,5 \mathrm{M}$

qsp para $100 \mathrm{~mL}$ com água milliQ estéril

No dia do uso, adicionar a cada $10 \mathrm{~mL}$ de STET/TWEEN 0,5 mL de RNAse $\mathrm{H}$ $10 \mathrm{mg} / \mathrm{mL}$ (Concentração final de $0,5 \mathrm{mg} / \mathrm{mL}$ ) e $5 \mathrm{mg}$ de lisozima $(50.000$ unid $/ \mathrm{mg}$ proteína).

\section{LAVAGEM DAS PLACAS}

Encher com água sanitária diluída 1:10 e após cerca de 1 hora enxaguar bem com água e por último passar água milliQ estéril. Ao final, os poços devem estar livres de qualquer precipitado. Secar as placas em estufa, embrulhá-las em papel alumínio e autoclavá-las para uso posterior. 


\section{Projetos funcionais}

\begin{tabular}{|c|c|}
\hline & Título \\
\hline 01 & Epidemiology and Management of Citrus Variegated Chlorosis \\
\hline 02 & $\begin{array}{l}\text { Optimization of In Vitro Regeneration Systems and Establishment of a Genetic of a Genetic Transformation } \\
\text { Protocol for Citrus SP. }\end{array}$ \\
\hline 03 & Identification and Molecular Analyses of Pathogenic Genes involved in the Citrus-Xylella fastidiosa Interaction. \\
\hline 04 & $\begin{array}{l}\text { Physiological aspects of sweet orange 'Pera' (Citrus sinensis L. Osb.) affected by CVC and its association to } \\
\text { pathogenicity of Xylella fastidiosa }\end{array}$ \\
\hline $\mathbf{0 5}$ & $\begin{array}{l}\text { Elaboration of a defined medium that allow the growtk of Xylella fastidiosa - CVC, using the information from } \\
\text { the annotation of genes sequenced by the Genome Project Consortium. }\end{array}$ \\
\hline 06 & $\begin{array}{l}\text { Evaluation of Molecular Markers for the Characterization of Xylella fastidiosa Strains Associated to CVC and } \\
\text { Coffee Leaf Scorch (Requeima do Cafeeiro) }\end{array}$ \\
\hline 07 & $\begin{array}{l}\text { The role of xanthan gum-associated genes in the pathogenecity and virulence of Xylella fastidiosa and potential } \\
\text { strategies for biological control of citrus CVC. }\end{array}$ \\
\hline 08 & Development of experimental assays for screening pathogenicity and adhesion of Xylella fastidios $a$ mutants. \\
\hline 09 & $\begin{array}{l}\text { Proteome of Xylella fastidiosa: I.Differential analysis for study of pathogenicity. UI. Construction of a 2D-PAGE } \\
\text { database. }\end{array}$ \\
\hline 10 & $\begin{array}{l}\text { Identification and characterization of } \overline{X y l e l l} a \text { fastidiosa genes expressed in infected citrus plants and regulated by } \\
\text { quorum sensors }\end{array}$ \\
\hline 11 & Expressed genes of Xylella fastidios $a$ at slow and fast growing conditions \\
\hline 12 & $\begin{array}{l}\text { Production and characterization of nonpathogenic mutants of Xylella fastidiosa CVC-strain, the causal agent of } \\
\text { the Citrus Variegated Chlorosis (CVC) }\end{array}$ \\
\hline 13 & Functional analysis of the Xylella fastidiosa Gum Operon and its relation to the Citrus Variegated Clorosis (CVC) \\
\hline 14 & Identification and Functional Analysis of Oxidative Stress Response Genes in Xylella fastidiosa \\
\hline 15 & Investigating the Role of an Endo-Polygalacturonase in the Pathogenicity of Xylella fastidiosa \\
\hline 16 & $\begin{array}{l}\text { Xylella fastidiosa - Papel de exoenzimas (proteases, celulases, liases do pectato) e da adesão (na planta e no } \\
\text { inseto vetor) na patogenicidade. }\end{array}$ \\
\hline 17 & Genetic and pathological relationships among Xylella fastidiosa strains \\
\hline 18 & $\begin{array}{l}\text { Functional analysis of the Xylella genome by identification of proteins and putative-virulence-relatade-low } \\
\text { molecular weight compounds. }\end{array}$ \\
\hline 19 & Establishment of conditions for the disruption of genes potentially involved in Xylella fastidios a pathogenesis. \\
\hline 20 & $\begin{array}{l}\text { Development of an experimental system for pathogenicity tests of Xylella fastidiosa of Citrus Variegated } \\
\text { Chlorosis in sweet orange (C.sinensis(L)Osb) }\end{array}$ \\
\hline 21 & $\begin{array}{l}\text { Amplified-open reading frames (AMORF) coupled to hybridization to reveal pathogenicity related genes of } \\
\text { Xylella fastidiosa. }\end{array}$ \\
\hline
\end{tabular}




\section{Curriculum vitae}

NOME:

DATA DE NASCIMENTO:
Adriana Yamaguti Matsukuma

24/09/1975

\section{FORMAÇÃO:}

- Ensino médio pelo Colégio Etapa, 1993.

- Bacharel em Ciências Biológicas com ênfase na área relacionada à Biologia Molecular pelaUniversidade Estadual de Campinas (UNICAMP), 1996.

\section{EXPERIENCIA PROFISSIONAL:}

- 1998-2000: Aluna de Pós-graduação no Departamento de Bioquímca, Instituto de Química da Universidade de São Paulo, com o projeto "Seqüenciamento e Anotação de parte do Genoma de Xylella fastidiosa" sob orientação do Prof.Dr. Sergio Verjovski-Almeida com suporte econômico dado pelo Conselo Nacional de Pesquisa (CNPq).

- 1995-1997: Estágios supervisionados em Bioquímica Molecular em Laboratório da Universidade Estadual de Campinas (UNICAMP) sob orientação da Profa.Dra. Maria Sumiko Arita Matsuura com os projetos: "Estudos de propriedades termodinânicas na transição alostérica da hemoglobina de Tropidurus itambere" e "Purificação de globinas de Helicops modestus" com suporte dado pela CAPES.

\section{PUBLICAÇÕES:}

- Carlos F.S.Bonafe, Adriana Y. Matsukuma and Maria S. A. Matsuura (1998). ATP-induced Tetramerization and Cooperativity in Hemoglobin of Lower Vertebrates. The Journal of Biological Chemistry. 274: 1196-1198.

- Emmanuel Dias Neto et al (2000). Shotgun sequencing of the human transcriptome with ORF expressed sequence tags. PNAS. 97(7): 34913496.

- A.J.Simpson et al (2000). The genome sequence of the plant pathogen Xylella fastidiosa. Nature. 406: 151-157. 